\title{
EDUCAÇÃO PARA A DEMOCRACIA NO BRASIL: FUNDAMENTAÇÃO FILOSÓFICA A PARTIR DE JOHN DEWEY E JÜRGEN HABERMAS
}

\author{
Tese de Doutorado
}

Orientador: Professor Associado Eduardo Carlos Bianca Bittar

\author{
Universidade de São Paulo \\ Faculdade de Direito \\ Departamento de Filosofia e Teoria Geral do Direito \\ São Paulo \\ 2014
}




\title{
EDUCAÇÃO PARA A DEMOCRACIA NO BRASIL: FUNDAMENTAÇÃO FILOSÓFICA A PARTIR DE JOHN DEWEY E JÜRGEN HABERMAS
}

Tese apresentada à Faculdade de Direito da Universidade de São Paulo, como requisito para a obtenção do título de Doutor em Filosofia e Teoria Geral do Direito.

Orientador: Prof. Associado Eduardo C. B. Bittar

\author{
Universidade de São Paulo \\ Faculdade de Direito \\ Departamento de Filosofia e Teoria Geral do Direito \\ São Paulo \\ 2014
}


Autorizo a reprodução e divulgação total ou parcial deste trabalho, por qualquer meio convencional ou eletrônico, para fins de estudo e pesquisa, desde que citada a fonte.

C117e Educação para a democracia no Brasil: fundamentação filosófica a partir de John Dewey e Jürgen Habermas / Guilherme Perez Cabral; orientador Eduardo Carlos Bianca Bittar. São Paulo, 2014.

$295 \mathrm{f}$.

Tese (Doutorado) - Faculdade de Direito. Departamento de Filosofia e Teoria Geral do Direito. Área de concentração: Filosofia e Teoria Geral do Direito.

1. Direito. 2. Filosofia do Direito. 3. Educação. 4. Democracia. 
Aos meus filhos, João Guilherme e Luis Felipe, O infinito e a completude que a linguagem não apreende, Sorrisos que tornam a metafísica irrelevante. 
E não pode haver direito autônomo sem a consolidação da democracia.

(Jürgen Habermas, Direito e Democracia, Vol. 02, 2011, p. 247) 


\section{SUMÁRIO}

RESUMO

ABSTRACT

RÉSUMÉ

INTRODUÇÃO .8

I. EDUCAÇÃO, DEMOCRACIA E MODERNIDADE: O CONTEXTO BRASILEIRO. 38

1. Democracia, direitos humanos e educação no ordenamento jurídico-constitucional brasileiro

2. A experiência histórico-constitucional da democracia no Brasil....................................60

3. Democracia, direitos humanos e educação no presente brasileiro .................................6 68

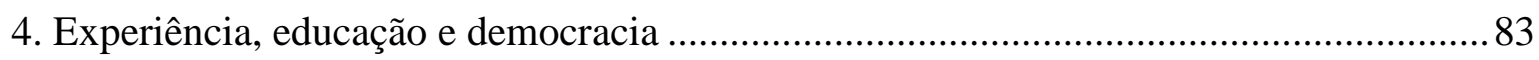

II. EDUCAÇÃO E DEMOCRACIA NA FILOSOFIA SOCIAL DE JOHN DEWEY.......87

1. A modernidade e a crítica na filosofia social de John Dewey ........................................96

2. A experiência, o pensar reflexivo e o crescimento. ...................................................... 111

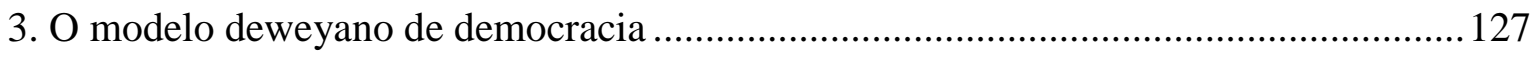

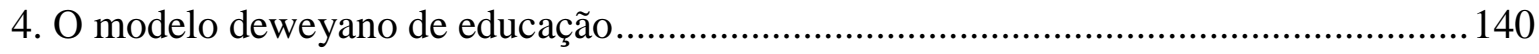

III. EDUCAÇÃO E DEMOCRACIA NA FILOSOFIA SOCIAL DE JÜRGEN HABERMAS

1. A modernidade e a crítica na filosofia social de Jürgen Habermas: razão e agir comunicativo, discurso e desenvolvimento da consciência moral ................................... 160

2. O modelo habermasiano de democracia ................................................................... 192

3. Uma concepção de educação a partir de Habermas ................................................... 210

IV. EDUCAÇÃO PARA A DEMOCRACIA NO BRASIL: APROXIMAÇÕES ENTRE JOHN DEWEY E JÜRGEN HABERMAS ................................................................. 222

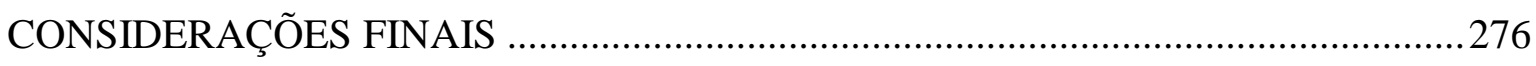

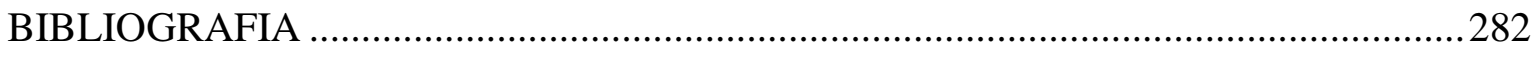




\section{RESUMO}

A tese tem como objetivo a reflexão sobre a educação para a democracia no Brasil, fundamentada na filosofia social de John Dewey, um dos principais nomes do pragmatismo norte-americano, e Jürgen Habermas, expressão da "segunda geração" da Escola de Frankfurt. A Constituição Federal de 1988 institui, em oposição ao passado autoritário brasileiro, um Estado Democrático de Direito que, amparado em vigoroso sistema de direitos humanos, tem a educação como um instrumento fundamental para sua consolidação. Os referenciais teóricos, em diálogo, permitem a leitura enriquecida do projeto constitucional, dentro da tradição da modernidade - em que ele se inscreve -, criticamente revisitada. Democracia e educação são apreendidas à luz do conceito de discurso e de seu potencial racional cognitivo e prático. A democracia se destaca como experiência racional-comunicativa e moral cognitivista de autodeterminação, em que, no processo discursivo de formação da opinião e da vontade e de solução compartilhada de problemas comuns, prevalece - sobre a atuação do sistema político e a orientando - a atuação da sociedade civil, na esfera pública. Lugar da realização do projeto moderno emancipatório, traz consigo a ideia da autonomia intersubjetivamente apreendida, no medium da linguagem voltada ao entendimento. A educação para a democracia, assim concebida discursivamente, não se distingue da aprendizagem orientada ao pleno desenvolvimento da pessoa. Compreende uma experiência educativa configurada a partir das seguintes diretrizes: a educação dialógica; o desenvolvimento cognitivo e moral do educando, a partir do exercício do pensamento reflexivo e da reconstrução criativa do inventário cognitivo, em vista da solução de problemas enfrentados no curso da experiência; a pedagogia diretiva, destacado o papel do docente, inversamente proporcional ao crescimento do educando; o diálogo interdisciplinar; e a participação da sociedade civil, que se distingue do Estado, sem ser assimilada pela economia. Entreve-se, desse modo, na socialização dialógica, a formação da individualidade na direção do estágio da consciência moral autônoma (pós-convencional), com competência e disposição comunicativa para a práxis discursiva, que marca a experiência social democrática.

PALAVRAS-CHAVES: EDUCAÇÃO, DEMOCRACIA, MODERNIDADE, DISCURSO, JOHN DEWEY, JÜRGEN HABERMAS 


\section{ABSTRACT}

This thesis has the objective to discuss the education for democracy in Brazil, based on the social philosophy of John Dewey, a leading name in American pragmatism, and Jürgen Habermas, the main representative of the "second generation" of the Frankfurt School. In opposition to the Brazilian authoritarian past, the Federal Constitution of 1988 establishes a democratic rule of law, which is supported by a powerful human rights system and has education as a fundamental instrument for its consolidation. The theoretical references, in dialogue, allow an enriched constitutional project's interpretation, within the tradition of modernity critically revisited. The democracy and the education are discussed under the discursive standpoint. Democracy stands as a rational-communicative and moral experience of self-determination. Herein, the civil society performs, in the public sphere, the discursive formation of opinion and will and the shared solutions to its common problems. It prevails over the political system performance and directs it. Democracy is the place where the modern emancipatory project occurs. It brings the idea of autonomy, intersubjectively grasped, in the medium of agreement oriented language. Therefore, the education for democracy discursively conceived is indistinguishable from the personality's full development education. It can be explained as an educative experience based on the following of guidelines: dialogical education; cognitive and moral development, based on reflective thinking's exercise and cognitive apparatus creative reconstruction, by means of problems solution in the course of the experience; the pedagogically-oriented education, highlighting the educator's role being inversely proportional to the student's growth; interdisciplinary dialogue; and the civil society's participation, distinguished for the State, without being assimilated by the economy. In this way, in the dialogic socialization, it is possible to glimpse the individuality's formation towards the autonomous moral conscience stage (post-conventional), where the person can achieve a communicative competence and disposition to the practical discourse, which marks the social democratic experience.

KEYWORDS: EDUCATION, DEMOCRACY，MODERNITY，DISCOURSE，JOHN DEWEY, JÜRGEN HABERMAS 


\section{RÉSUMÉ}

Cette thèse a pour but la réflexion sur l'éducation pour la démocratie au Brésil, fondée sur la philosophie sociale de John Dewey, l'un des principaux auteurs du pragmatisme nordaméricain et Jürgen Habermas qui incarne la deuxième génération de l’École de Francfort. La Constitution Fédérale de 1988 institue, par opposition au passé autoritaire brésilien, une Démocratie fondée sur l' État de Droit qui, épaulée par un vigoureux système des droits de l'homme, a l'éducation comme un outil essentiel pour sa consolidation. Les référentiels théoriques, en dialoguant, enrichissent la lecture du projet constitutionnel qui s'inscrit dans la tradition de la modernité, critiquement revisitée. Démocratie et éducation sont apréhendées à la lumière du concept de discours et de son potentiel rationnel cognitif et pratique. La démocratie se détache en tant qu'expérience rationnelle-communicative et morale cognitiviste d'auto-détermination dans laquelle prévaloit - sur l'action du système politique tout en l'orientant - l'action de la société civile dans la sphère publique, dans le processus discursif de formation de l'opinion et da la volonté et de solution partagée des problèmes communs. Lieu de réalisation du projet moderne émancipatoire, elle renferme l'idée d'autonomie intersubjectivement appréhendée au medium du langage orienté vers l'entendement. L'éducation pour la démocratie, ainsi conçue, ne se distingue pas de l'apprentissage tournée vers le plein épanouissement de l'individu. Elle implique une expérience éducative envisagée à partir des directives suivantes: l'éducation dialogique, le développement cognitif et moral de l'apprenant basé sur l'exercice de la pensée réflexive et de la reconstruction créative de l'inventaire cognitif en vue de la solution des problèmes affrontés au cours de l'expérience; la pédagogie directive dans laquelle se détache le rôle de l'enseignant inversement proportionnel à l'épanouissement de l'apprenant; le dialogue interdisciplinaire et la participation de la société civile qui se distingue de l'État sans pour autant être assimilée par l'économie. On entrevoit ainsi dans la socialisation dialogique, la formation de l'individualité vers le stade de la conscience morale autonome (postconventionnelle) ayant de la compétence et de la disposition communicative pour la praxis discursive qui marque l'expérience sociale démocratique.

MOTS-CLÉS: ÉDUCATION， DÉMOCRATIE，MODERNITÉ，DISCOURS，JOHN DEWEY, JÜRGEN HABERMAS 


\title{
INTRODUÇÃO
}

\section{Educação para a democracia: o resgate do projeto moderno emancipatório}

\begin{abstract}
Na medida em que o pai é o arquétipo da autoridade, pois que a experiência original de toda a autoridade, a democracia é, de acordo com a concepção que nela predomina, uma sociedade sem pai. Tem por objetivo constituir uma comunidade de iguais. $O$ seu princípio é o ajustamento harmônico; em sua forma mais primitiva é uma organização matriarcal onde os homens que vivem juntos são irmãos, filhos da mesma mãe (Hans Kelsen, A democracia, 2000, p. 189).
\end{abstract}

\begin{abstract}
Se pensarmos agora a fase da adolescência, numa experiência imaginária, como condensada num único momento crítico, no qual o adolescente adotaria como que pela primeira vez e de uma ao mesmo tempo inexorável e totalizante, uma atitude hipotética em face dos contextos normativos de seu mundo da vida, ficará clara então a natureza do problema que todos têm de enfrentar quando da passagem do plano convencional para o plano pósconvencional do juízo moral. De um só golpe, o mundo social (...) se vê desenraizado e despido de sua validade nativa. Se agora, o adolescente não pode e não quer voltar ao tradicionalismo e à identidade inquestionada do mundo de que provém, ele tem que reconstruir em seus conceitos fundamentais (sob pena de total desorientação) as ordenações da esfera normativa que se desintegraram diante da força desveladora de seu olhar hipotético (Jürgen Habermas, Consciência Moral e Agir Comunicativo, 2003, p. 155-156).
\end{abstract}

1. Em 2014, completaram-se cinquenta anos do Golpe Militar de 31 de março de 1964. Nada a comemorar. E, a fim de que não repita, nada, também, a esquecer.

Institucionalizou, mais uma vez, relações autoritárias entre o Estado e a sociedade civil brasileira, e, assim, afastou o país, novamente em sua breve história, da experiência democrática. Usurpando para si o discurso em defesa da democracia e dos direitos humanos ${ }^{1}$, renovou, por vinte anos, sob a superfície da aparente normalidade das práticas e dos contratempos da vida cotidiana, padrões de interação social pautados no não-diálogo, na repressão, no emprego imediato da violência, sem rebuço.

É sobre o chão do profundo desrespeito aos direitos humanos e da histórica inexperiência da democracia, legado do passado autoritário e enraizado no pano de fundo

${ }^{1}$ VIOLA, Sólon Eduardo Annes. Direitos humanos no Brasil: abrindo portas sob neblina. In SILVEIRA, Rosa Maria Godoy e outros (org.). Educação em direitos humanos: Fundamentos teórico-metodológicos. João Pessoa: Editora Universitária, 2007, p. 126. 
das relações sociais, que se edifica o Estado Democrático de Direito promulgado pela Constituição Federal de 1988.

Não só ingênuo, seria temerário ignorar o peso desse passado do qual somos herdeiros: uma tradição do golpe em que o uso da palavra democracia traz consigo "além de certa preferência pela ambigüidade, o gosto por doses maciças de cinismo"2.

Passados mais de vinte e cinco anos, a despeito dos progressos significativos que o país vivenciou no campo econômico, acompanhado, certamente, de avanços na área social, e do inegável grau de institucionalização e estabilização dos procedimentos políticoeleitorais - não mais acometidos de modo ostensivo por pretensões golpistas -, a democracia brasileira permanece sobrecarregada pelo ingente desafio de sua consolidação.

De um lado, o reconhecimento do amplo rol de direitos fundamentais no texto constitucional, incorporando os resultados de sua afirmação histórica, na Modernidade, convive, ainda, com a facticidade de sua ineficácia.

O mesmo Brasil que ocupa a posição de sétima maior economia do mundo ${ }^{3}$, quando analisado sob a ótica do índice de desenvolvimento humano (IDH) - indicador utilizado pela Organização das Nações Unidas que considera, além da dimensão econômica da renda, aspectos da saúde (expectativa de vida) e da educação -, despenca para a $85^{\text {a }}$ colocação na classificação mundial ${ }^{4}$.

O retrato revela-se mais alarmante ante a consideração de que, compondo-se como uma medida média, o índice mencionado não considera o fato de que, não obstante a redução significativa, nos últimos trinta anos, da população em situação de extrema pobreza - vivendo com menos de um dólar por dia -, aproximadamente $8 \%$ dos brasileiros

\footnotetext{
${ }^{2}$ WEFFORT, Francisco C. Por que democracia? 2 $2^{\mathrm{a}}$ ed. São Paulo: Brasiliense, 1984, p. 25 e 33.

${ }^{3}$ CENTRE FOR ECONOMICS AND BUSINESS RESEARCH (CEBR). Cebr's World Economic League Table. Londres, 26/12/2013, p. 14. Disponível em: http://www.cebr.com/reports/cebr-world-economicleague-table/. Acesso em 20/10/2014.

${ }^{4}$ PROGRAMA DAS NAÇÕES UNIDAS PARA O DESENVOLVIMENTO (PNUD). Human Development Report 2013. The Rise of the South: Human Progress in a Diverse World. Nova Iorque, 2013, p. 01. Disponível em: http://hdr.undp.org/sites/default/files/reports/14/hdr2013_en_complete.pdf. Acesso em $31 / 01 / 2014$.
} 
ainda sobrevivem nesta indigna condição ${ }^{5}$. Mantém-se o país, desse modo, entre as mais agudas desigualdades sociais do mundo ${ }^{6}$.

Em relação à educação - objeto da presente tese -, pautando-se em dados quantitativos, segundo os quais o Brasil está próximo de atingir a universalização do ensino fundamental, o IDH não prescinde da complementação por análises qualitativas. Nesse ponto, vale a menção aos resultados do exame aplicado, em 2012, no âmbito Programa Internacional de Avaliação de Alunos (sigla, em inglês, PISA). Revelam que quase a metade $(49,2 \%)$ dos estudantes brasileiros com 15 anos de idade - faixa etária em que, em princípio, já haveriam de ter concluído o referido nível de ensino - apresenta graves dificuldades até mesmo no campo da leitura. Permanece abaixo do nível 02 de proficiência, considerado, conforme critérios do Programa, um nível básico, em que os estudantes conseguem, no máximo, reconhecer o tema central de um texto sobre um assunto familiar, relacionando-o, de forma simples, com o senso comum. Um nível, enfim, no qual "começam a demonstrar habilidades de leitura que os habilitarão a participar da vida de forma efetiva e produtiva"7.

Trata-se de diagnóstico de precariedade que pode ser estendido a todo o extenso rol de direitos individuais, sociais e políticos, reconhecidos na Constituição Federal: promessas legais que, projetando a dignidade da pessoa ${ }^{8}$, remetem às condições básicas de participação racional no debate público e, com isso, de exercício da cidadania.

\footnotetext{
${ }^{5}$ BRASIL. PRESIDÊNCIA DA REPÚBLICA. SECRETARIA DE DIREITOS HUMANOS (SDH/PR). Segundo Relatório Nacional do Estado Brasileiro apresentado no Mecanismo de Revisão Periódica Universal do Conselho de Direitos Humanos das Nações Unidas - 2012. Brasília, 2012, p. 02. Disponível em: http://www.direitoshumanos.gov.br. Acesso em 30/05/2012.

${ }^{6}$ NÚCLEO DE ESTUDOS DA VIOLẾNCIA (NEV/USP). $4^{\circ}$ Relatório nacional sobre os direitos humanos no Brasil. São Paulo: Universidade de São Paulo/Núcleo de Estudos da Violência, 2010, p. 16. Disponível em: http://www.nevusp.org/downloads/down248.pdf. Acesso em 31/01/2014.

${ }^{7}$ ORGANIZAÇÃO PARA A COOPERAÇÃO E DESENVOLVIMENTO ECONÔMICO (OCDE). Country note. Brazil. Programme for International Student Assessment. Results from PISA 2012, p. 03. Disponível em: http://www.oecd.org/pisa/keyfindings/PISA-2012-results-brazil.pdf. Acesso em 17/09/2014; ORGANIZAÇÃO PARA A COOPERAÇÃO E DESENVOLVIMENTO ECONÔMICO (OCDE). PISA 2009 Results: Executive summary. 2010, p. 06. Disponível em: http://www.pisa.oecd.org. Acesso em 25/04/2012.

${ }^{8}$ SARLET, Ingo Wolfgang. Dignidade da pessoa humana e direitos fundamentais na Constituição Federal de 1988. Porto Alegre: Livraria do advogado, 2011, p. 101.
} 
De outro lado, efeito de continuidade experiencial, dentro da nova situação política $^{9}$, revivem instituições, práticas e hábitos marcados pelo não-diálogo, pela verticalidade e pelo autoritarismo, combinados com traços do patrimonialismo, do paternalismo, do mandonismo e do clientelismo, dentro de uma tradição política que antecede a Ditadura Militar e ampara sua antipatia pela democracia.

Reproduz-se uma ambiência em que a atuação governamental, como polo condutor da sociedade ${ }^{10}$, pode, em grande medida, alhear-se do engajamento comunicativo da sociedade civil, na esfera pública ${ }^{11}$ e, diante da desarticulação do público ${ }^{12}$, manter um fluxo de comunicação unilateralizado que segue a "direção centrífuga, que vai do centro para fora, contrariando a direção espontânea que se origina na periferia social"13.

Pois convive com uma sociedade civil que, em processo de aprendizagem da cidadania, na própria (in)experiência da democracia, revela, ainda, tímido envolvimento e participação nos processos decisórios político-institucionais; é mais consumidora do que ator social nas relações com o Estado. Enquanto súdito democrático ${ }^{14}$, o cidadão quer a proteção e a prestação do Estado, desobrigando-se, todavia, à participação na formação de sua vontade ${ }^{15}$.

Desse modo, a sociedade brasileira experiencia um processo perverso. A precariedade dos direitos humanos, intimamente ligada à inexperiência democrática, prejudica o enriquecimento da própria vivência da democracia, a qual, alicerçada nesses direitos, constitui, ao mesmo tempo, mecanismo fundamental para seu reconhecimento, ampliação e concretização ${ }^{16}$.

\footnotetext{
${ }^{9}$ MOISÉS, José Álvaro. Os brasileiros e a democracia. Bases sociopolíticas da legitimidade democrática. São Paulo: Ática, 1995, p. 27.

${ }^{10}$ FAORO, Raymundo. Os donos do poder. Formação do patronato político brasileiro. Volume 02. 11 $1^{\mathrm{a}}$ Ed. São Paulo: Globo, 1995, p. 740.

${ }^{11}$ BITTAR, Eduardo C. B. A discussão do conceito de direito: uma reavaliação a partir do pensamento habermasiano. Boletim da Faculdade de Direito. Universidade de Coimbra. Vol. LXXXI, 2005, p. 808.

${ }_{12}$ DEWEY, John. The public and its problems. Swallow Press/Ohio University Press/Athens, 1991, p. 131.

${ }^{13}$ HABERMAS, Jürgen. Direito e democracia: entre factibilidade e validade. Volume 02. Trad. Flávio Beno Siebeneichler. Rio de Janeiro: Tempo Brasileiro, 2011, p. 115.

14 BECK, Ulrich. La sociedad del riesgo. Hacia una nueva modernidad. Trad. Jorge Navarro e outros. Barcelona: Paidós Surcos, 2006, p. 315.

${ }^{15}$ FAORO, Os donos do poder, 1995, p. 740 e 744.

${ }^{16}$ COMITÊ NACIONAL DE EDUCAÇÃO EM DIREITOS HUMANOS. Plano Nacional de Educação em Direitos Humanos. Brasília: Secretaria Especial dos Direitos Humanos/Ministério da Educação/Ministério da Justiça/UNESCO, 2007, p. 24. Disponível em: http://portal.mj.gov.br/sedh/edh/pnedhpor.pdf. Acesso em 23/01/2014.
} 
Com isso, não podia ser diferente, o país tem dificuldade de fazer avançar o seu afirmado Estado Democrático de Direito (Art. $1^{0}$ da Constituição Federal), para além do sentido meramente político-formal da democracia representativa. Sofre para superar as conquistas eleitorais modernas da pluralidade partidária, da renovação periódica dos mandatos de cargos executivos e legislativos e, da parte do cidadão comum, da prática isolada e pouco crítica" do direito de votar: o "exercício meramente eleitoral da cidadania"18.

Num quadro em que a brasilidade ainda está "mais para a subserviência do que para a autonomia" ${ }^{19}$, vive-se menos a horizontalidade da figura metafórica sociedade sem pai, referida por Kelsen com base na teoria freudiana ${ }^{20}$ : o sentido autêntico em que a democracia pode ser pensada, na tradição do iluminismo, de "uma sociedade de quem é emancipado" ${ }^{21}$; mais a forma democrática coabitando, ainda com Freud, com a horda acrescenta-se, de "cidadãos" menores ${ }^{22}$ que mal sabem ler - "conduzida por um chefe",23.

2. Nesse cenário contraditório, a democracia brasileira pode ser inserida no quadro da revisão histórica do projeto de modernidade.

Seguindo o sentido etimológico do termo, modernus, a modernidade expressa a consciência de uma época que se posiciona como o novo em oposição ao passado ${ }^{24}$. Começa, para nós, com o Renascimento. E se consolida, com a filosofia Iluminista, como um projeto otimista de futuro que alimentou grandes esperanças no aprimoramento infinito, material e moral, da humanidade, por meio da razão. A atividade racional proporcionaria à

${ }^{17}$ DEWEY, The public and its problems, 1991, p. 122.

${ }^{18}$ RANIERI, Nina Beatriz Stocco. O estado democrático de direito e o sentido da exigência de preparo para o exercício da cidadania, pela via da educação. Tese apresentada para inscrição em concurso visando a obtenção do título de Livre-docente, junto ao Departamento de Direito de Estado da Faculdade de Direito da Universidade de São Paulo. São Paulo, 2009, p. 385.

${ }^{19}$ BITTAR, Eduardo C. B. Estudos sobre ensino jurídico: pesquisa, metodologia, diálogo e cidadania. $2^{-}$Ed. São Paulo. Atlas, 2006, p. 43.

${ }^{20}$ KELSEN, Hans. A democracia. Trad. Ivone Castilho Benedetti e outros. São Paulo: Martins Fontes, 2000 , p. 189.

${ }^{21}$ ADORNO, Theodor, W. Educação e Emancipação. São Paulo: Paz e Terra, 2004, p. 142.

${ }^{22}$ FAORO, Os donos do poder, 1995, p. 744; DEMO, Pedro. Cidadania menor. Algumas indicações quantitativas de nossa pobreza política. Petrópolis: Vozes, 1992, p. 108.

${ }^{23}$ FREUD, Sigmund. Psicologia das massas e análise do eu. In Obras completas. Volume 15. Psicologia das massas e análise do eu e outros textos (1920-1923). Trad. Paulo César de Souza. São Paulo: Cia das Letras, 2011, p. 83.

${ }^{24}$ HABERMAS, Jürgen. Modernidade - um projeto inacabado. In ARANTES, Otília B. Fiori e ARANTES, Paulo Eduardo. Um ponto cego no projeto moderno de Jurgen Habermas: arquitetura e dimensão estética depois das vanguardas. São Paulo: Brasiliense, 1992, p. 100 e 101; BITTAR, Eduardo C. B. O direito na pósmodernidade (e reflexões frankfurtianas). $2^{\underline{a}}$ ed. Rio de Janeiro: Forense Universitária, 2009, p. 33. 
humanidade emancipada não "apenas o controle das forças naturais, mas também a interpretação de si mesmo e do mundo, o progresso moral, a justiça das instituições sociais e mesmo a felicidade dos homens"25. Assim, "a filosofia da história colocou sua esperanças nesse progresso. O progresso técnico-científico parecia levar consigo um progresso da civilização, moral e político"26.

Mas "no século XX, muito pouco restou desse otimismo"27. A profecia iluminista de Victor Hugo, de que "o século XIX é grande, mas o século XX será feliz",28, não se concretizou. Nos descaminhos da modernidade, o progresso material, técnico-científico restou desacoplado do processo de desenvolvimento moral e social ${ }^{29}$.

A razão, identificada originariamente como fator de emancipação, acabou reduzida ao seu aspecto cognitivo-instrumental, de enfrentamento, manipulação e autoafirmação com êxito no mundo objetivo ${ }^{30}$. Numa realização deformada na história ${ }^{31}$, foi expandida, sob tal perspectiva, a todos os âmbitos da vida e, dentro de uma postura tecnicista e cientificista, virou-se contra o próprio homem. Afinal, no mundo em que tudo se torna um “dado técnico", priva-se "o outro de sua condição idiossincrática como 'tu', convertendo-o em mero "isso"”: "tudo é meio para alcançar um outro meio. Inclusive o próprio sujeito, degradado a mera função, renovável e substituível" ${ }^{\text {32 }}$.

Tal racionalidade justificou e forneceu instrumental técnico-científico para que o Século XX fosse cenário das barbaridades, das irracionalidades e do abismo moral dos campos de concentração, cujo paradigma do terror foi Auschwitz; das guerras civis, entre conterrâneos, e das guerras mundiais; dos genocídios de judeus, curdos, tutsis entre outros

${ }^{25}$ HABERMAS, Modernidade - um projeto inacabado, 1992, p. 110 e 111.

${ }^{26}$ HABERMAS, Jürgen. Teoría y praxis: estudios de filosofia social. Trad. Salvador Más Torres e Carlos Moya Espí. 2a ed. Madrid: Tecnos, 1990, p. 314.

${ }^{27}$ HABERMAS, 1992, Modernidade - um projeto inacabado, p. 110; HABERMAS, Jürgen. Teoria do agir comunicativo. Sobre a crítica da razão funcionalista. Tomo 02. Trad. Flávio Beno Siebeneichler. São Paulo: Editora WMF Martins Fontes, 2012, p. 590.

${ }^{28}$ HUGO, Victor. Os Miseráveis. Tomo 02. Trad. Francisco O. Barros. São Paulo: Cosac \& Naify, 2002, p. 545.

${ }^{29}$ BITTAR, Eduardo C. B. Justiça e liberdade na filosofia do direito de Jürgen Habermas. Revista dos Tribunais, ano 101, vol. 918, abril/2012, p. 236.

${ }^{30}$ HABERMAS, Jürgen. Teoria do agir comunicativo. Racionalidade da ação e racionalização social. Tomo 01. Trad. Paulo Astor Soethe. Revisão Técnica Flávio Beno Siebeneichler. São Paulo: Editora WMF Martins Fontes, 2012, p. 35.

31 HABERMAS, Jürgen. $O$ discurso filosófico da modernidade. Trad. Luiz Sérgio Repa e Rodnei Nascimento. São Paulo: Martins Fontes, 2002, p. 439.

32 FERRAZ JUNIOR. Tércio Sampaio. Responsabilidade sem culpa, culpa sem responsabilidade na sociedade tecnológica. In FABIANI, Emerson Ribeiro (org.). Impasses e aporias do direito contemporâneo. Estudos em homenagem a José Eduardo Faria. São Paulo: Saraiva, 2011, p. 140 e 141. 
povos; das torturas e assassinatos praticados pelas ditaduras militares na América do Sul; do Apartheid, reconhecido legalmente na África do Sul e praticado mundialmente contra a população negra; da morte por inanição, principalmente nos países africanos; das desigualdades sociais e regionais; enfim, de todas as formas de violências, contra o outro diferente, a quem, não obstante todo o progresso econômico, técnico e científico experimentado, não se reconheceu humanidade ${ }^{33}$.

Na experiência social, em que forças produtivas se perverteram em destrutivas, emancipação degenerou-se em opressão, racionalidade em irracionalidade ${ }^{34}$, viu-se o avanço da barbárie ao ponto de fazer do século XX o "mais assassino de que temos registro, tanto na escala, frequência e extensão da guerra que o preencheu (...) como também pelo volume único de catástrofes humanas que produziu, desde as maiores fomes da história até o genocídio sistemático" 35. O pior é que "Passamos a nos habituar ao morticínio", "passamos a nos habituar ao desumano. Aprendemos a tolerar o intolerável”"36.

O último século concretizou, enfim, a profecia da Dialética do esclarecimento, segundo a qual “A maldição do progresso irrefreável é a irrefreável regressão”, ${ }^{37}$. Faz pensar a importância de, ao olhar para o futuro, não repetir tantos erros históricos diagnosticados.

3. Aludidas deficiências, contradições, regressos que fulminam o ingênuo otimismo iluminista, entretanto, não devem, absolutamente, conduzir ao abandono do projeto moderno, renegando os potenciais emancipatórios da razão e os progressos experimentados pela humanidade nos últimos dois séculos.

O conjunto de valores herdados do Iluminismo, como afirma Hobsbawn, corresponde a "uma das poucas coisas que nos separam de uma queda acentuada nas trevas". E se, de fato, em sua concepção original, tinha muito de "superficial e

33 BITTAR, Justiça e liberdade na filosofia do direito de Jürgen Habermas, 2012, p. 236; BITTAR, O direito na pós-modernidade, 2009, p. 86 a 99.

${ }^{34}$ HABERMAS, Jürgen. A nova opacidade: a crise do Estado-providência e o esgotamento das energias utópicas. Revista de Comunicação e Linguagem, nº 02, 1985, p. 116 e 117.

${ }^{35}$ HOBSBAWN, Eric. Era dos extremos. O breve século XX: 1914-1991. 2a ed. Trad. Marcos Santarrita. Rev. Téc. Maria Célia Paoli. São Paulo: Cia das Letras, 2000, p. 22.

${ }^{36}$ HOBSBAWN, Eric. Sobre história. Ensaios. Trad. Cid K. Moreira. São Paulo: Cia das Letras, 2013, p. 351 e 362 .

37 ADORNO, Theodor W. \& HORKHEIMER, Max. Dialética do Esclarecimento. Fragmentos Filosóficos. Trad. Guido Antonio de Almeida. Rio de Janeiro: Zahar, 1985, p. 41. 
intelectualmente ingênuo", servindo de "fundamento intelectual ao imperialismo ocidental", também é certo que o progresso da cultura ocidental, a partir do Século XVIII,

(...) foi obtido preponderantemente ou em sua totalidade sob a influência do Iluminismo, por governos que ainda são chamados, em benefício dos estudantes de história, "absolutistas esclarecidos", por revolucionários e reformadores, liberais, socialistas e comunistas, todos pertencentes à mesma família intelectual. Não foi obtido por seus críticos ${ }^{38}$.

É fundamental, nesse sentido, conforme preocupação constante na filosofia social de John Dewey, afastar-se do costume dos homens de pensar a partir de opostos extremos e, assim, formular crenças "em termos de ou isso ou aquilo, entre os quais não há possibilidades intermediárias" 39 .

Com efeito, abandonar o "velho", no caso, o moderno, a partir da prática tipicamente moderna, obsessiva, contínua e irrefreável, de negar o lugar do que veio antes, "limpando o terreno" para, em nome de um novo projeto, recomeçar sempre do zero ${ }^{40}$, não resolve o problema. A filosofia que atua com base em simples rejeição e oposição acaba por negligenciar todo um conjunto de problemas que emergem da crítica e da busca pela superação do que lhe antecedeu ${ }^{41}$.

Tal é o enfoque a partir do qual Dewey debruça-se sobre a modernidade, em sua reconstrução pragmatista da filosofia ${ }^{42}$. A crítica à modernidade faz-se com seu amparo, isto é, sem perder de vista as experiências por ela proporcionadas.

Esse é também o enfoque proposto por Habermas com seu esclarecimento biiluminista. Afastando-se tanto da crença moderna ingênua de progresso contínuo, por meio da razão e da ciência, como das críticas arrasadoras do discurso da modernidade - citando, aqui, dentre outros, a partir de Nietzsche, M. Heidegger, G. Bataille, J. Derrida e M. Foucault ${ }^{43}$ - "retoma esta tradição procurando, ao mesmo tempo, superá-la criticamente" ${ }^{44}$. Acredita, em síntese, que, diante do "projeto inacabado" de modernidade, a humanidade

\footnotetext{
${ }^{38}$ HOBSBAWN, Sobre história, 2013, p. 349.

${ }^{39}$ DEWEY, John. Experiência e educação. Trad. Renata Gaspar. Petrópolis/RJ: Vozes, 2010, p. 19.

${ }^{40}$ BAUMAN, Zygmunt. A modernidade líquida. Trad. Plínio Dentzien. Rio de Janeiro: Jorge Zahar, 2001, p. 36.

${ }^{41}$ DEWEY, Experiência e educação, 2010, p. 23.

${ }^{42}$ DEWEY, John. Reconstruction in philosophy. Mineola/New York: Dover Publications, 2004.

${ }^{43}$ HABERMAS, $O$ discurso filosófico da modernidade, 2002, p. 141.

44 SIEBENEICHLER, Flávio Beno. Jürgen Habermas: razão comunicativa e emancipação. $3^{3}$ ed. Rio de Janeiro: Tempo Brasileiro, 1989, p. 25.
} 
deveria aprender com os desacertos de seus ambiciosos programas e não tomá-lo, definitivamente, por fracassado ${ }^{45}$.

Em suma, para os dois filósofos, a revisão crítica da modernidade, apontando os regressos e a barbárie existentes e reconhecendo, também, seus avanços, importa não abandoná-la. Mantêm dela, acima de tudo e apesar dos descaminhos históricos, a aposta moral iluminista: a "crença inabalável na capacidade de autodeterminação do sujeito, arraigada na faculdade da razão, e a recusa radical de qualquer forma de heteronomia" ${ }^{46}$.

4. Eis o quadro dentro do qual é desenvolvido o tema da presente tese, A educação para a democracia no Brasil: fundamentação filosófica a partir de John Dewey e Jürgen Habermas.

Adota, como linha de reflexão, a referida abordagem crítica revisora do projeto inacabado de modernidade. Fugindo ao raciocínio de extremos, assume um olhar que não abre mão das experiências e dos aprendizados proporcionados por essa mesma modernidade.

Nesse sentido, aposta na experiência democrática como locus para a realização desse projeto emancipatório da humanidade, identificando, ainda, como caminho para sua consolidação, o lugar fundamental do esclarecimento, eleito pelo Iluminismo: a educação.

Sob tal perspectiva, pretende fundamentar filosoficamente a educação para a democracia no Brasil, de maneira a contribuir com a construção hermenêutica de um sentido enriquecido e ampliado desses dois institutos que alicerçam o ordenamento jurídico nacional: a democracia, que, logo no Art. $1^{\underline{0}}$ da Constituição, adjetiva a "República Federativa do Brasil", constituindo-a como um Estado Democrático de Direito; e a educação, incumbida tanto do desenvolvimento pleno da pessoa como do "preparo para o exercício da cidadania" (Art. 205) e, com isso, voltada, em última análise, "à promoção e conservação do próprio Estado Democrático de Direito" ${ }^{\text {"47 }}$.

\footnotetext{
${ }^{45}$ HABERMAS, Modernidade - um projeto inacabado, 1992, p. 118.

${ }^{46}$ FREITAG, Bárbara. A questão da moralidade: da razão prática de Kant à ética discursiva de Habermas. Tempo social. Revista de Sociologia da USP. Volume 01, no 02, São Paulo, 2ํ semestre de 1989, p. 16.

47 RANIERI, $O$ estado democrático de direito e o sentido da exigência de preparo para o exercício da cidadania, pela via da educação, 2009, p. 380.
} 
Isso, a partir de dois referenciais teóricos em diálogo. No âmbito do pragmatismo norte-americano, a filosofia social reconstruída de John Dewey (1859-1952), destacando as conexões entre suas teorias da experiência, do pensar, a partir de problemas, e da constituição social e crescimento do sujeito, no continuum experiencial; e, intimamente ligadas a elas, suas propostas de democracia e educação progressiva. No âmbito da teoria crítica da sociedade, a filosofia de Jürgen Habermas (1929), expressão da "2a geração" da Escola de Frankfurt, em especial as contribuições da teoria da ação comunicativa, da ética do Discurso, da revisitação ao modelo de desenvolvimento moral cognitivista de Lawrence Kohlberg e, referida a todas elas, sua concepção da democracia.

A despeito das escolas filosóficas distintas a que pertencem e das peculiaridades e diferenças que marcam suas linhas de reflexão, são notáveis as confluências da teoria social dos dois autores. Com efeito, o pensamento pragmatista não só de Dewey mas também o de Charles S. Peirce, George H. Mead e Lawrence Kohlberg, constituem importante componente interno da teoria social habermasiana ${ }^{48}$ - dado que, aliás, mitiga a crítica de Hans Joas acerca da "negligência" da filosofia alemã em relação ao pragmatismo e, em especial, à obra deweyana ${ }^{49}$. $\mathrm{O}$ próprio Habermas, exaltando o teor radicalmente democrático dessa "variante americana da filosofia da práxis", destaca nela se apoiar "quando surge o problema de compensar a debilidade do marxismo com relação à teoria democrática" $"$.

A convergência, nesse sentido, revela-se bastante nítida e frutífera na orientação dos autores por uma práxis social emancipatória, que se perfaz, dentro de uma abordagem filosófica comunicativa, na experiência da democracia.

Em ambos, o abandono da filosofia da consciência e de sua crença numa razão pura e monológica, aprioristicamente competente para uma "comunhão solitária" com a verdade e a justiça, dá lugar à compreensão da linguagem como medium social da

48 PINZANI, Alessandro. Habermas. Porto Alegre: Artmed, 2009, p. 21; COMETTI, Jean-Pierre. Jürgen Habermas e o pragmatismo. ROCHLITZ, Rainer (coord.). Habermas e o uso público da razão. Trad. Léa Novaes. Rio de Janeiro: Tempo brasileiro, 2005, p. 58.

49 JOAS, Hans. Pragmatism and social theory. Chicago: University of Chicago Press, 1993, p. 94 e 116.

${ }^{50}$ HABERMAS, Jürgen. Um perfil sociológico-político: entrevista com Jürgen Habermas. Trad. Wolfgang Leo Maar. Dossiê Habermas. Novos estudos. CEBRAP 18, Setembro/1987, p. 78 e 79. 
formação da individualidade e, como lugar da realização da racionalidade, o critério último da construção do conhecimento e definição da moralidade $e^{51}$.

A verdade e a moral são referidas ao discurso, a práxis da argumentação, orientada ao entendimento em relação a um problema, um desacordo sobre objeto da comunicação. Tornam-se pretensões de validade cuja racionalidade, é condicionada à comunicação e, no contexto comunicativo, à sua "disposição de sofrer crítica" e "capacidade de se fundamentar" ${ }^{\prime 52}$. Observa-se, assim, que, com Dewey e Habermas, é atribuído um conteúdo cognitivo também aos juízos morais, que, com isso, "não se limitam a dar expressão às atitudes afetivas, preferências ou decisões contingentes de cada falante". Porque podem ser fundamentados, no discurso, pressupõe-se a possibilidade de se distinguir, nessa matéria, tal como ocorre com as questões de verdade, os juízos válidos dos inválidos ${ }^{53}$.

Os autores, desse modo, podem aproveitar todo o sentido cognitivo e prático ${ }^{54}$ Dewey diz instrumental e consumatório ${ }^{55}$ - inerente à interação comunicativa.

Cognitivo porque, no diálogo, a suscetibilidade de crítica e a exigência de fundamentação tornam o conteúdo do pensar exteriorizado passível de correção ${ }^{56}$; todos os eventos, conceitos, crenças "tornam-se sujeitos a reconsideração e a revisão; são readaptados para que enfrentem as exigências da conversação" ${ }^{\text {, }}$. A linguagem possibilita, dessa forma, a construção e reconstrução cooperativa das verdades e a fundamentação moral das normas de ação ${ }^{58}$, superando os equívocos e preconceitos a que estão todos sujeitos no solilóquio da razão e os particularismos semânticos do contexto específico em que se está imerso. Afinal, "No discurso, uma visão de mundo deve ser trabalhada pela contradição dos outros de tal modo que os horizontes de sentido de todos os participantes

${ }^{51}$ DEWEY, Reconstruction in philosophy, 2004, p. 21; HABERMAS, O discurso filosófico da modernidade, 2002 , p. 447.

${ }^{52}$ HABERMAS, Teoria do agir comunicativo, Tomo 01, 2012, p. 32, 34, 35, 45, 47 e 48.

${ }^{53}$ HABERMAS, Jürgen. Consciência Moral e Agir Comunicativo. Trad. Guido A. de Almeida. Rio de Janeiro: Tempo Brasileiro, 2003, p. 147 e 155.

${ }^{54}$ HABERMAS, Jürgen. Direito e democracia: entre factibilidade e validade. Volume 01. $2^{\mathrm{a}}$ Ed. Trad. Flávio Beno Siebeneichler. Rio de Janeiro: Tempo Brasileiro, 2012, p. 190 e 191.

55 DEWEY, John. Experiência e natureza. In Experiência e natureza; Lógica: a teoria da investigação; A arte como experiência; Vida e educação; Teoria da vida moral. Trad. Murilo Otávio Rodrigues Paes Leme, Anísio S. Teixeira e Leônidas Gontijo de Carvalho. Coleção Os Pensadores. São Paulo: Abril Cultural, 1980, p. 39.

${ }_{56}$ HABERMAS, Teoria do agir comunicativo, Tomo 01, 2012, p. 49.

${ }^{57}$ DEWEY, Experiência e natureza, 1980, p. 29.

58 JOAS, Pragmatism and social theory, 1993, 18; BITTAR, A discussão do conceito de direito, 2005, p. 808. 
ampliem - e se imbriquem cada vez mais - graças à progressiva descentração da perspectiva de cada um deles"

Prático, pois a qualidade racional do resultado exige condições dialógicas, orientadas ao entendimento e isentas de violência, em que o "comum acordo que se pretende alcançar por via comunicativa precisa, ao fim e ao cabo, sustentar-se sobre razões" $" 60$.

Forma-se, assim, o pressuposto racional-comunicativo fundamental, através do qual se vislumbra a realização do projeto moderno emancipatório revisitado ${ }^{61}$ e a partir do qual pode ser desenvolvida a reflexão sobre democracia e a educação para a experiência democrática, pautada nos referenciais teóricos adotados.

5. Sob tais bases, a democracia, dentro de uma perspectiva comum a Dewey e Habermas, significa, em primeiro lugar, um modelo de experiência social que se efetiva como uma práxis coletiva de autodeterminação, de autolegislação. Isso, no sentido de que, nela, os cidadãos, sujeitos de direito, devem se entender, também, ativa e comunicativamente, na condição de seus autores, protagonistas do processo de convivência ${ }^{62}$, ou ainda, valendo-se da expressão de Paul Ricoeur, narradores das histórias que, no âmbito de uma história plural, contam sobre si mesmos ${ }^{63}$.

Para tanto, a experiência democrática, ao mesmo tempo, é compreendida como um processo de formação racional-discursiva da opinião e da vontade, tomada de decisões coletivas, encaminhamento e solução de problemas comuns ${ }^{64}$.

Trata-se de um processo, contudo, que, enriquecido e ampliado de significação, envolve mas não pode, apenas, depender ou ser expresso em termos de instituições políticas $^{65}$. Não se restringe, absolutamente, à institucionalização de regras procedimentais

\footnotetext{
${ }^{59}$ HABERMAS, Jürgen. Verdade e justificação. Ensaios filosóficos. Trad. Milton Camargo Mota. $2^{2}$ ed. São Paulo: Loyola, 2009, p. 71, 93 e 94.

${ }^{60}$ HABERMAS, Teoria do agir comunicativo, Tomo 01, 2012, p. 47; HABERMAS, Direito e democracia, Vol. 01, 2012, p. 191.

${ }^{61}$ SIEBENEICHLER, Jürgen Habermas, 1994, p. 47.

${ }^{62}$ HABERMAS, Direito e democracia, Vol. 01, 2012, p. 157.

${ }^{63}$ RICOEUR, Paul. O Justo. A justiça como regra moral e como instituição. . Tomo 01. Trad. Ivone C. Benedetti. São Paulo: Martins Fontes, 2008, p. 25 e 28.

${ }^{64}$ HABERMAS, Direito e democracia, Vol. 02, 2011, p. 19, 24 e 45; HONNETH, Axel. Democracy as reflexive cooperation: John Dewey and the theory of democracy today. Political Theory, vol. 26, n⿳⺈ 06, Dez/1998, p. 774 e 775.

${ }^{65}$ DEWEY, John. Freedom and culture. Nova York: Prometheus Books, 1989, p. 97.
} 
mínimas próprias ao jogo democrático, como o sufrágio universal, a pluralidade partidária, a periodicidade eleitoral e a tomada de decisões com base na regra da maioria ${ }^{66}$ - dado, aliás, que não deixa de ser observado, apesar das deficiências destacadas, no Brasil.

Pois, radicada, com Habermas, no princípio do discurso, a validez da decisão remete ao assentimento de todos os afetados, enquanto participantes da argumentação ${ }^{67}$. Assim, a democracia é concebida como uma experiência social comunicativa maior, na qual o sistema político se insere como um momento apenas, um "segmento estreito da vida pública"68. Destaca-se, nela, a importância do momento de "debate, discussão e persuasão" ${ }^{69}$, cuja arena é a esfera pública e os protagonistas os atores da sociedade civil. Em suma, o nível discursivo do debate público, estruturado dentro do Estado de Direito, passa a representar "a variável mais importante" da democracia ${ }^{70}$.

O modelo democrático refere-se, assim, à ideia fundamental de um fluxo comunicacional, numa direção centrípeta, de fora para dentro do "centro" político, em que a atuação governamental é precedida e vinculada à da sociedade civil, na esfera pública, a qual se destaca como o espaço comunicativo fundamental, enraizado no mundo da vida, de identificação, elaboração, debate, tratamento e encaminhamento de problemas comuns; de luta por reconhecimento e convencimento de pretensões; de tomada de posições, articulação de demandas e construção de opiniões públicas e de soluções compartilhadas. Nesse cenário, onde fracassam os "padrões de coordenação que se apoiam em valores, normas e rotinas de entendimento convencionais", a estrutura político-governamental aparece como mecanismo regulador, de forma vinculante - isto é, "acima do limiar da consciência" -, de temas e problemas de integração social identificados, elaborados e debatidos pela sociedade civil $^{71}$.

Pensada nesse formato, a experiência da democracia assume a configuração de um sistema semidireto, valorizando a complementaridade entre a representação e os

${ }^{66}$ MOISÉS, Os brasileiros e a democracia, 1995, p. 38 e 77; HABERMAS, Direito e democracia, Vol. 02, 2011, p. 26 e 27; BOBBIO, Norberto. O futuro da democracia. Uma defesa das regras do jogo. Trad. Marco Aurélio Nogueira. $5^{\text {a }}$ Ed. Rio de Janeiro: Paz e Terra, 1992, p. 18, 19, 20 e 37.

${ }^{67}$ HABERMAS, Consciência moral e agir comunicativo, 2003, p. 116; HABERMAS, Jürgen. Escritos sobre moralidad y eticidad. Trad. Manuel Jiménes Redondo. Barcelona: Ediciones Paidós/ICE Universidad Autónoma de Barcelona, 1991, p. 101.

${ }^{68}$ HABERMAS, Direito e democracia, Vol. 02, p. 220.

${ }^{69}$ DEWEY, The public and its problems, 1991, p. 208.

${ }^{70}$ HABERMAS, Direito e democracia, Vol. 02, 2011, p. 28.

${ }^{71}$ HABERMAS, Direito e democracia, Vol. 02, 2011, p. 22, 24, 25, 41, 46, 115 e 121; HABERMAS, Jürgen. A inclusão do outro. Estudos de teoria política. Trad. George Sperber, Paulo Astor Soethe e Milton Camargo Mota. 3를 ed. São Paulo: Loyola, 2007, p. 291. 
mecanismos e canais de participação direta nas atividades governamentais e na definição de políticas públicas ${ }^{72}$. Tudo isso, de qualquer forma, referido às demandas, aos debates, às propostas e às opiniões públicas oriundas da atuação da sociedade civil.

A relevância conferida à esfera pública, percebendo-a como complexa rede comunicativa intermediária entre as biografias individuais e grupos privados e a formação da vontade institucional, vai de par, assim, com uma concepção de sociedade democrática que não se restringe, dentro de uma perspectiva liberal, a uma mera massa de indivíduos isolados, concorrentes entre si e com objetivos tão incongruentes, que a vontade da maioria somente pode ser descoberta aritmeticamente ${ }^{73}$; que um fim coletivo não pode significar mais que "uma negociação entre interesses particulares opostos". Tampouco a identifica, na outra ponta, na linha do republicanismo, como um corpo social quase que orgânico, cuja auto-organização política poderia se renovar, apenas, com respaldo no consenso ético entre seus membros ${ }^{74}$.

Abrem-se perspectivas para a consolidação, o fortalecimento da democracia a partir de uma concepção normativa que coloca no centro do debate a indispensabilidade da participação ativa dos atores da sociedade civil, fazendo uso de sua liberdade comunicativa, e os imensos potenciais cognitivos e práticos do procedimento argumentativo, em vista da solução compartilhada de problemas comuns.

Num cenário pós-metafísico pluralista, em que a justiça de uma decisão e a verdade de seus pressupostos não podem mais ser impostas tampouco afirmadas de antemão e de uma vez por todas, o procedimento e o arranjo comunicativo no espaço público aparecem como o critério da legitimidade das decisões do Estado e da ordem jurídica: uma legitimidade, em última análise, referida à expectativa da qualidade racional dos resultados obtidos conforme o processo e medida, racionalmente, pela resgatabilidade discursiva da pretensão de validade da política e do direito ${ }^{75}$.

\footnotetext{
72 BENEVIDES, Maria Victoria de Mesquita. A cidadania ativa. Referendo, plebiscito e iniciativa popular. $3^{\text {a }}$ ed. São Paulo: Ática, 2003, p. 15.

${ }^{73}$ HONNETH, Democracy as reflexive cooperation, 1998, p. 767.

${ }^{74}$ HABERMAS, Direito e democracia, Vol. 02, 2011, p. 19; HABERMAS, A inclusão do outro, 2007, p. 284.

${ }^{75}$ HABERMAS, Consciência moral e agir comunicativo, 2003, 149; HABERMAS, Direito e democracia, Vol. 01, 2012, p. 50; HABERMAS, Direito e democracia, Vol. 02, 2011, p. 27 e 28.
} 
6. A centralidade do diálogo para a definição ampliada do processo democrático, submete-o, contudo, sem dúvida, a exigentes condições de possibilidade ${ }^{76}$.

Com efeito, exige uma ambiência dialógica, no espaço público, que se aproxime, tanto quanto possível, de uma situação ideal de fala, imunizada contra violência e desigualdade: um contexto em que a tomada da decisão realize-se sob condições de comunicação, orientada ao entendimento, que possibilitem o acesso dos concernidos ao discurso, com iguais chances de contribuir para o debate, excluindo-se, dessa forma, toda formação de coerção, "com exceção da coerção do argumento melhor". Trata-se, enfim, daquelas condições de simetria que todo aquele que ingressa na argumentação tem que pressupor como suficientemente preenchidas ${ }^{77}$.

Em Robert Dahl, isso aparece na forma de critérios ideais a serem atendidos pelo processo democrático de tomada de decisão, envolvendo oportunidades iguais e adequadas de participação efetiva, a igualdade de voto e o controle da agenda. Dahl fala, ainda, da compreensão esclarecida sobre as matérias a serem reguladas, critério que remete ao "processo de formação de um demos informado e esclarecido, por exemplo através da educação e da discussão pública"78.

Nesse sentido, combinadas com referida ambiência, numa relação direta de favorecimento recíproco, a democracia demanda, também, a competência e a disposição comunicativa dos cidadãos. Isto é, diante dos problemas cotidianos e com vistas à sua solução, o cidadão deve não só estar apto mas também motivado à participação racional no debate público, justificando, com razões, suas pretensões de validade ${ }^{79}$.

A presença de tais elementos conduz, em Dewey, à aliança bem sucedida entre o uso adequado dos métodos científicos e as práticas democráticas ${ }^{80}$. Corresponde à pesquisa cooperativa de soluções aos problemas, enfrentados pela sociedade ${ }^{81}$, que remete não ao

\footnotetext{
${ }^{76}$ FREITAG, A questão da moralidade, 1989, p. 37; HABERMAS, Direito e democracia, Vol. 02, 2011, p. 09 ;

${ }^{77}$ HABERMAS, Consciência moral e agir comunicativo, 2003, p. 111 e 112; HABERMAS, Teoria do agir comunicativo, Tomo 01, 2012, p. 60, 61 e 63

${ }^{78}$ HABERMAS, Direito e democracia, Vol. 02, 2011, p. 42; DAHL, Robert A. A democracia e seus críticos. Trad. Patrícia de Freitas Ribeiro. Revisão da tradução: Aníbel Mari. São Paulo: Editora WMF Martins Fontes, 2012, p. 176.

${ }^{79}$ HABERMAS, Teoria do agir comunicativo, Tomo 01, 2012, p. 48; HABERMAS, Direito e democracia, Vol. 01, 2012, p. 155 e 156.

${ }^{80}$ DEWEY, Freedom and culture, 1989, p. 81.

${ }^{81}$ DEWEY, The public and its problems, 1991, p. 167 e 184; BERNSTEIN, Richard J. The resurgence of pragmatism. Social research, vol. 59, n , 1992, p. 814.
} 
descaminho moderno da cultura de especialistas $^{82}$, mas ao hábito investigativo e experimental, num ambiente comunicativo, em que prevaleça a "liberdade de pesquisa, a tolerância em relação a visões diferentes, a liberdade de comunicação, a distribuição do que for descoberto a cada indivíduo, como consumidor intelectual final". Tudo isso, para o autor, está envolvido "no método democrático tanto quanto no método científico" 83.

A democracia, desse modo, pode se atualizar como fator de racionalidade da solução de problemas sociais, partindo-se da premissa de que "as chances de se encontrar respostas inteligentes aos problemas aumentam com a qualidade da cooperação dos pesquisadores envolvidos", isto é, na medida em que mais envolvidos possam, sem constrangimentos e com iguais direitos, introduzir críticas, argumentos e reflexões ${ }^{84}$.

7. Tais padrões, de qualquer forma, expressam somente possibilidades de interação comunicativa e exercício da cidadania, incorporadas a uma hermenêutica jurídicoconstitucional alinhada criticamente com a modernidade, a partir da filosofia de Dewey e de Habermas. Não estão, certamente, dados como ponto de partida, contrastando mesmo com o cenário brasileiro de inexperiência democrática e déficits de direitos humanos, herdado do passado autoritário.

Por outro lado, à luz da teoria deweyana da experiência ${ }^{85}$, parece certo que a cultura democrática e, dentro dela, a prevalência de hábitos de pensar, agir e conviver democraticamente não podem emergir senão da própria experiência e reconstrução positiva da experiência da vida democrática. A lenta e gradual, mas "verdadeira reforma do modo de pensar" ${ }^{\prime 86}$ caminha junto com a reconstrução da experiência em que se atualiza; no caso, com o "longo, difícil e, por vezes, bastante penoso" processo de democratização ${ }^{87}$.

\footnotetext{
${ }^{82}$ HABERMAS, Modernidade - um projeto inacabado, 1992, p. 110.

${ }^{83}$ DEWEY, Freedom and culture, 1989, p. 81.

${ }^{84}$ HONNETH, Democracy as reflexive cooperation, 1998, p. 772, 773 e 775.

${ }^{85}$ DEWEY, Reconstruction in philosophy, 2004, p. 54; DEWEY, Experiência e educação. 2010, p. 35 a 38.

${ }^{86}$ KANT, Immanuel. Resposta à pergunta: que é o Iluminismo? In A paz perpétua e outros opúsculos. Trad. Artur Morão. Lisboa: Edições 70, 2004, p. 13

${ }^{87}$ MOISÉS, Os brasileiros e a democracia, 1995, p. 36 e 84.
} 
Aludida teoria da experiência apresenta-a como a interação contínua entre os sujeitos e o ambiente, em que todos se modificam reciprocamente ${ }^{88}$. Desse modo, se, por um lado, desautoriza a atribuição de qualquer caráter inevitável, determinado à constituição do indivíduo e ao curso de sua história; por outro, induz uma continuidade experiencial do processo de vida: as experiências de hoje partem daquilo que o sujeito já experienciou e influenciarão o modo como o sujeito, doravante, com um olhar modificado, experienciará.

Nesse sentido, o pensar e o experimentar democraticamente a vida social não são dados ou dádivas dos quais o sujeito em crescimento possa partir. Como ressalta Dewey, não se pode admitir a crença numa natureza humana democrática que "quando deixada a si mesma, liberta de restrições externas arbitrárias, tenderá a produzir instituições democráticas que funcionam de modo bem sucedido" ${ }^{, 89}$.

A constituição da individualidade efetiva-se como um contínuo processo experiencial em relação com: um processo eminentemente social, conforme a psicologia social de George H. Mead, pensamento que influencia de modo marcante a filosofia de Habermas e a de Dewey, constituindo, por isso, ponte fundamental entre ambos. Segundo Mead, o eu é um reflexo individual, particular e único, da interação social comunicativa; surge dela, com a característica de ser um objeto para si, uma autoconsciência, uma experiência de si que pressupõe o outro, pois não pode ocorrer senão de forma indireta, por meio da assunção da atitude dos outros em relação ao si mesmo ${ }^{90}$.

Assim, é no âmbito das experiências sociais que atualizam as tradições culturais, as instituições, os padrões e as expectativas de comportamento, que são moldadas nossas atitudes emocionais e intelectuais; "nossas sensibilidades básicas e nossos modos de receber e responder a todas as condições com as quais nos deparamos na vida"91; delineadas nossas abordagens da realidade; descortinadas nossos horizontes de possibilidades; finalmente, construída e reconstruída a (in)experiência democrática.

88 TEIXEIRA, Anísio. A pedagogia de Dewey (Esboço da teoria de educação de John Dewey). In DEWEY, John, Experiência e natureza; Lógica: a teoria da investigação; A arte como experiência; Vida e educação; Teoria da vida moral. Trad. Murilo Otávio Rodrigues Paes Leme, Anísio S. Teixeira e Leônidas Gontijo de Carvalho. Coleção Os Pensadores. São Paulo: Abril Cultural, 1980, p. 113.

${ }^{89}$ DEWEY, Freedom and culture, 1989, p. 97.

${ }^{90}$ MEAD, George Herbert. Mind, self and society: from the standpoint of a social behaviorist. Edited and with a introduction by Charles W. Morris. Chicago/London: The University of Chicago Press, 1992, p. 136, $138,139,142,164,186,201$ e 226.

${ }^{91}$ DEWEY, Experiência e educação, 2010, p. 35. 
Dependendo mas não se reduzindo à dimensão política institucional e expressando, também, atitudes, uma forma de conduta de vida dos atores sociais, a democracia não prescinde de um processo de aprendizagem ${ }^{92}$.

8. Nesse contexto, aclara-se a tarefa e a significância da educação como mecanismo fundamental para a consolidação da democracia. A educação, aqui, entendida num sentido ampliado, para além da instituição escolar. Dada a premissa de que "Simultaneamente vivemos, experimentamos e aprendemos" "93, não se separa da experiência de vida, abrangendo, na linha do Artigo $1^{\circ}$ da Lei de Diretrizes e Bases ( $n^{\circ}$ 9.394/1996), todos “os processos formativos que se desenvolvem na vida familiar, na convivência humana, no trabalho, nas instituições de ensino e pesquisa, nos movimentos sociais e organizações da sociedade civil e nas manifestações culturais".

Para sua fundamentação, a proposta pedagógica progressiva de Dewey e a filosofia social habermasiana oferecem importantes contribuições.

É bem verdade que Habermas não possui uma teoria acabada sobre o assunto. No entanto, a teoria do agir comunicativo e a releitura do modelo de desenvolvimento da consciência moral de Lawrence Kohlberg, à luz da ética do Discurso, permitem a referência, sem nenhum desconforto, a uma pedagogia da ação comunicativa, na expressão utilizada por José Pedro Boufleuer ${ }^{94}$. E aludidos elementos justificadores de uma proposta educacional habermasiana, não afirmada diretamente pelo filósofo frankfurtiano, possibilitam, também nessa matéria, significativas aproximações com o pensamento deweyano, onde se encontram mais profundas e diretas reflexões sobre o tema.

Pensar a educação para a democracia, a partir de Dewey e Habermas, pressupõe reconhecer estar-se diante de tarefa extremamente complexa e delicada, num cenário de inexperiência democrática e continuidades históricas desfavoráveis, arraigadas nas instituições e práticas sociais, dentre as quais as educacionais. Pois é a partir dele que os hábitos de pensar, agir e conviver democráticos são formados.

${ }^{92}$ DEWEY, Freedom and culture, 1989, p. 97 e 101; MOISÉS, Os brasileiros e a democracia, 1995, p. 55 e 77.

${ }_{93}^{93}$ TEIXEIRA, A pedagogia de Dewey, 1980, p. 115.

${ }^{94}$ BOUfLEUER, José Pedro. Pedagogia da ação comunicativa. Uma leitura de Habermas. $3^{\underline{a}}$ ed. Ijuí: Unijuí, 2001. 
Tudo isso, porém, sem fazer da exigência excessiva uma "forma sublime de sabotagem" "95; sem se alquebrar frente a uma realidade "que não mais reconhece qualquer alternativa para si mesma" 96 .

Implica, nesse sentido, uma filosofia da ação, pela educação, que não negligencia o peso das condições objetivas que conformam o processo educacional e, por conseguinte, as contradições que ele deve assimilar ${ }^{97}$. Reconhece que a educação tem limitações, mas, ao mesmo tempo, como destaca Flávia Schilling, ao responder a indagação $O$ que cabe à educação fazer em direitos humanos?, que se, sozinha, ela não resolve o problema - dos direitos humanos e, soma-se aqui, de democracia - é certo, também, que, sem ela, pode haver solução ${ }^{98}$.

A perspectiva construída na aproximação dos referenciais teóricos induz a compreensão da educação para democracia como caminho em que vale a pena apostar para realização do projeto moderno de emancipação. Faz-se emancipatória na medida em que vislumbra uma experiência educativa que habilita, habitua, dispõe os sujeitos a experiências humanas coletivas gradual e processualmente mais democráticas e, portanto, melhores, em termos racionais, cognitivos e morais $^{99}$.

A tese fundamenta filosoficamente essa experiência educativa, a partir das contribuições de Dewey e de Habermas, nas seguintes diretrizes:

i) Educação dialógica. Em Dewey e em Habermas, a abordagem social-comunicativa da formação da individualidade remete, na linha de Mead, à centralidade do diálogo, do uso da linguagem orientada pelo entendimento, como dado indispensável da experiência educativa.

Pois a competência e a disposição comunicativa do sujeito dificilmente poderiam emergir de uma experiência antitética ao diálogo, com o emprego empobrecido, viciado,

95 ADORNO, Theodor, W. Escritos sociológicos I. Obra completa 08. Trad. Agustín González Ruiz. Madrid, España: Akal, 2004, p. 132.

${ }^{96}$ BAUMAN, A modernidade líquida, 2001, p. 30.

97 ADORNO, Theodor W. Teoria da semicultura. Trad. Newton Ramos de Oliveira, Bruno Pucci e Cláudia B. M. de Abreu. Educação \& Sociedade $\mathrm{n}^{\mathrm{0}}$ 56, ano XVII, dez/1996.

98 SCHILLING, Flávia. O que cabe à educação fazer em direitos humanos? VI Encontro Anual da Associação Nacional de Direito Humanos - Pesquisa e Pós-graduação - ANDHEP, Brasília/DF, 17/09/2010.

${ }^{99}$ DEWEY, Reconstruction in philosophy, 2004, p. 70; DEWEY, Experiência e educação, 2010, p. 34 e 35. 
da fala, como ocorre, no paradigma tradicional de ensino - a que Dewey se opõe ${ }^{100}$-, com a prática docente da transmissão unilateral de um saber, imunizado contra o discurso.

Remete, sim, a uma interação dialógica em que - sinônimo de um inesgotável processo de aprendizagem ${ }^{101}$ e reconstrução positiva das experiências - a comunicação, orientada pelo entendimento, manifesta todo o sentido cognitivo e prático.

Assim, a educação passa a ser compreendida como "espaço privilegiado do agir comunicativo" 102 , cuja experiência pode propiciar, ao lado do desenvolvimento das capacidades cognitivas do sujeito em crescimento, sua habilitação e habituação ao diálogo para a solução, de modo cada vez mais racional, de problemas experienciados, "esparramando" tal competência e disposição aos demais âmbitos da ação social.

A mente individual e sua conversa internalizada consigo mesma, que constitui o pensar, são reflexos da conversa com os outros $^{103}$. A partir dela, podem se desenvolver dentro de um paradigma racional-comunicativo, cooperativo, em que a verdade e a justiça são percebidas não como resultado da prática solitária de uma razão monológica autossuficiente, mas como fruto do exercício da interlocução ${ }^{104}$.

ii) Desenvolvimento da capacidade cognitiva. Abrange, também, sem dúvida, o desenvolvimento cognitivo do sujeito em crescimento, a ser atualizado mediante o aprendizado baseado em problemas efetivamente experienciados. Afinal, é a solução de dificuldades vivenciadas que define, na lição de Dewey, o pensar, em seu melhor sentido, o inteligente, reflexivo ${ }^{105}$.

O pensar é compreendido, pragmaticamente, como um processo em relação indissociável com a conduta de vida ou, mais especificamente, com uma dificuldade no curso da ação. Origina-se da perplexidade diante de um conflito na experiência, que exige do sujeito, a partir do "estoque" de experiências anteriores, a inferência de uma solução 106 - uma ideia cuja validade não é determinada apenas por sua erudição ou plausibilidade

\footnotetext{
${ }^{100}$ DEWEY, Experiência e educação, 2010, p. 46 e 47.

101 TEIXEIRA, A pedagogia de Dewey, 1980, p. 118.

${ }^{102}$ BOUFLEUER, Pedagogia da ação comunicativa, 2001, p. 17.

${ }^{103}$ DEWEY, Experiência e natureza, 1980, p. 31; MEAD, Mind, self and society, 1992, p. 47 e 50.

${ }^{104}$ BITTAR, A discussão do conceito de direito, 2005, p. 808.

${ }^{105}$ DEWEY, John. How we think. Mineola, New York: Dover Publications, 1997, p. 02.

${ }^{106}$ DEWEY, How we think, 1997, p. 12 e 72.
} 
teórica, mas, precipuamente, por sua "funcionalidade para a solução de problemas enfrentados pelos sujeitos no curso de sua conduta" ${ }^{\prime 107}$.

Por isso, a educação deve ser direcionada não ao depósito de informações na mente do educando, apelando a um despropositado pensar sem qualquer referência à existência, em sua experiência, de "alguma dificuldade que o incomode e perturbe seu equilíbrio" O desenvolvimento da capacidade de pensar somente pode se efetivar a partir da práxis que o define, o esforço de solução de problemas com que se defronta. Exige, dessa forma, do sujeito em crescimento, a reorganização das próprias estruturas e recursos cognitivos para a colmatagem das lacunas identificadas na experiência, apreendendo-a de modo cada vez mais denso e completo ${ }^{109}$.

É desse modo que a experiência educativa confere ao educando, gradualmente, a aptidão de sempre mais educação, com cada vez mais autonomia intelectual. Pois, num continuum experiencial positivo, habilita-o, cognitivamente, diante de um universo que se revela cada vez mais complexo, a responder, de modo adequado, aos novos problemas, às novas perplexidades que nele se apresentam ${ }^{110}$.

O pensar, nesse seu melhor sentido, supera o modo menos cuidadoso e rigoroso de aceitar ideias acriticamente, maculado por tendências irracionais que assediam a mente e por hábitos irrefletidos que se acumulam na personalidade ${ }^{111}$.

É-lhe inerente um aspecto positivo da cientificidade, herdada da modernidade, qual seja, a atitude científica: o hábito da mente marcado pela curiosidade intelectual; pela disposição investigativa e experimental; pelo rigor metodológico; pela postura falibilista; e pelo emprego comunicativo das ideias como possibilidades de respostas - na linguagem habermasiana, pretensões de validade ${ }^{112}$-, em vista da solução de problemas na experiência, aceitas porque confirmadas experimentalmente, mas, ainda assim, sempre abertas à crítica e à revisão ${ }^{113}$.

107 JOAS, Pragmatism and social theory, 1993, p. 20.

${ }^{108}$ DEWEY, How we think, 1997, p. 12.

${ }^{109}$ DEWEY, How we think, 1997, p. 80; DEWEY, Experiência e educação, 2010, p. 48.

${ }^{110}$ DEWEY, Reconstruction in philosophy, 2004, p. 106; DEWEY, Experiência e educação, 2010, p. 48 e 50; DEWEY, John. Democracia e educação: capítulos essenciais Apresentação e comentários de Marcus Vinicius da Cunha. Trad. Roberto Cavallari Filho. São Paulo: Ática, 2007, p. 11.

${ }^{111}$ DEWEY, How we think, 1997, p. 01, 02 e 26.

${ }^{112}$.HABERMAS, Teoria do agir comunicativo, Tomo 01, 2012, 45.

${ }^{113}$ BERNSTEIN, The resurgence of pragmatism, 1992, p. 814; DEWEY, Freedom and culture, 1989, p. 111; DEWEY, How we think, 1997, 33 e 72; DEWEY, Reconstruction in philosophy, 2004, p. 90. 
Desenvolvido dentro de uma perspectiva comunicativa - numa busca cooperativa pela verdade ${ }^{114}$ (e, também, pelo justo) - e espraiado aos conflitos morais e sociais cotidianos que angustiam a humanidade ${ }^{115}$, o pensar reflexivo, favorece a solução compartilhada e racional de problemas comuns, no âmbito do espaço público democrático.

iii) Desenvolvimento da consciência moral. O desenvolvimento cognitivo e a competência e disposição comunicativa, a partir do diálogo para solução de problemas, harmonizam-se com o desenvolvimento da capacidade de juízo moral. Possibilitam ao sujeito alcançar o estágio de autonomia (pós-convencional), no qual a moralidade descolada das normas sociais convencionadas, internalizadas pela criança - somente pode ser fundamentada, procedimentalmente, no Discurso ${ }^{116}$.

Lawrence Kohlberg, nesse ponto, faz a ponte entre os referenciais teóricos: seu modelo, revisitado por Habermas, fundamenta-se, conforme ressalta o próprio autor, no pensamento deweyano, para atribuir ao percurso do desenvolvimento moral o caráter de um desenvolvimento cognitivo ${ }^{117}$. É identificado, assim, como um processo de aprendizagem, no qual, diante de conflitos de ação moralmente relevantes, o sujeito constrói e reconstrói as estruturas e instrumentos de pensamento que subjazem sua faculdade de resolver os problemas morais.

A moral como um crescimento $^{118}$ pode, então, ser concebida dentro de modelo composto por três níveis de interação social - pré-convencional, convencional e pósconvencional, este último representado pelo Discurso ${ }^{119}$. Indicam a introdução do sujeito no mundo social, das "relações interpessoais legitimamente reguladas"120, e sua caminhada, após a "adolescência moral”, da heteronomia para a autonomia ${ }^{121}$.

\footnotetext{
114 JOAS, Pragmatism and social theory, 1993, p. 19.

${ }^{115}$ DEWEY, Reconstruction in philosophy, 2004, p. xxiv.

${ }^{116}$ HABERMAS, Consciência moral e agir comunicativo, 2003, p. 199; BITTAR, Eduardo C. B. Justiça e emancipação: reflexões jusfilosóficas a partir do pensamento de Jürgen Habermas. Tese apresentada em concurso de Professor Titular junto ao Departamento de Filosofia e Teoria Geral do Direito da Faculdade de Direito da Universidade de São Paulo. São Paulo, 2011, p. 239 e 240.

${ }^{117}$ KOHLBERG, Lawrence. La Democracia en la escuela secundaria: educando para una sociedad mas justa. Trad. Maria Mercedes Oraison. Chaco: Universidad Nacional del Nordeste, 1992, p. 03 e 04.

118 DEWEY, John. Ethics. The Later Works 1925-1953. Volume 07 (1932). Edited by Jo Ann Boydston. Southern Illinois University, 2008, p. 12.

${ }^{119}$ HABERMAS, Consciência moral e agir comunicativo, 2003, p. 193.

${ }^{120}$ HABERMAS, Teoria do agir comunicativo, Tomo 01, 2012, p. 193.

121 HABERMAS, Consciência moral e agir comunicativo, 2003, p. 154 e 155; FREITAG, A questão da moralidade, 1989, p. 16; DEWEY, Ethics, 2008, p. 12 e 13.
} 
A educação, nesse sentido, forma hábitos democráticos de pensar, agir e conviver na medida em que pode conduzir o sujeito à autonomia, intersubjetivamente compreendida e referida à consciência moral pós-convencional, hábil e disposta ao discurso, onde radica o critério último da moralidade $e^{122}$.

iv) Pedagogia diretiva e o papel docente. A experiência educativa assume, ademais, um caráter diretivo. Ao se afastar da filosofia de extremos, reconhece que a oposição ao passado autoritário não precisa postular a liberdade sem limites.

Afinal, a liberdade fundamental na democracia é intersubjetiva, comunicativa, referida, portanto, a um agir que se orienta pelo entendimento ${ }^{123}$. E envolve responsabilidade. Pressupõe a atitude reflexiva da pessoa com o que pensa, faz e diz ${ }^{124}$. Por isso, a liberdade não é oposta à disciplina. Com Dewey, a disciplina e, mais propriamente, a disciplina da mente, possibilitando o exercício inteligente, racional do pensar, é sinônimo de liberdade. É emancipadora das tradições e dos hábitos irrefletidos e também da ilusão de liberdade da ação comandada por forças libidinais ${ }^{125}$ e impulsivas ${ }^{126}$.

Sendo assim, o processo educacional, pensado a partir dos referenciais teóricos, não supõe, absolutamente, a possibilidade da formação quase que mágica da criança deixada por si mesma ${ }^{127}$. O pensar e agir democraticamente não são dádivas da personalidade humana que se atualizam espontaneamente, como também não o são as posturas autoritárias. São hábitos construídos experiencialmente e, assim, consolidados em espaços e instituições sociais ${ }^{128}$.

Por isso, não prescinde da atuação docente. Não, porém, a da experiência deseducativa, em termos de democracia, do ensino unilateralizado, em que o docente não se comunica, faz comunicados ${ }^{129}$, impondo respostas a perguntas nem sequer formuladas na experiência do educando, que ignora ${ }^{130}$. A atuação docente de que não se prescinde é

${ }^{122}$ FREITAG, A questão da moralidade, 1989, p. 36.

${ }^{123}$ DEWEY, The public and its problems, 1991, p. 150; HABERMAS, Direito e democracia, Vol. 01, 2012, p. 155.

${ }^{124}$ HABERMAS, Verdade e justificação, 2009, p. 103.

${ }^{125}$ FREUD, Psicologia das massas e análise do eu, 2011, p. 43.

${ }^{126}$ DEWEY, Experiência e educação, 2010, p. 66, 68 e 73.

${ }^{127}$ DEWEY, How we think, 1997, p. 43.

${ }^{128}$ DEWEY, Freedom and culture, 1989, p. 88.

${ }^{129}$ FREIRE, Paulo. Pedagogia do Oprimido. 50a ed. rev. e atual. Rio de Janeiro: Paz e Terra, 2011, p. 80.

${ }^{130}$ DEWEY, Experiência e educação, 2010, p. 21. 
diretiva, mas no sentido de que estabelece as condições ambientais e apresenta o caminho da experiência democrática.

Não dispensa, por isso, a tarefa de transmissão, exposição de conteúdos, inversamente proporcionais ao desenvolvimento e maturidade do educando, em termos de autonomia de reflexão e pesquisa. Ao docente, enfim, cumpre trazer a criança às tradições, consensos, padrões de interação social que possibilitarão sua integração no universo da linguagem e no mundo da vida comum, do qual se fala. Pois é na medida em que, no processo de aprendizagem, torna-se participante da comunicação, que a individualidade é socialmente formada; que, diante de um problema, pode proceder ao diálogo interno do pensar, dispondo de experiências e informações para a construção de respostas ${ }^{131}$.

Nessa direção e no horizonte de experiências comuns, o sujeito - compreendido que tudo, no final das contas, não passa de pretensões de validade - pode, então, concordar ou discordar de uma oferta de fala, no âmbito do discurso, habilitando-se e dispondo-se à crítica e à fundamentação daquelas pretensões que fizer suas ${ }^{132}$.

v) O diálogo interdisciplinar aparece como contraponto à degeneração pela singularização ${ }^{133}$, fruto da fragmentação cartesiana do saber e da autorreferencialidade das especialidades científicas, linguística e racionalmente fechadas em si.

O conhecimento afunilado em grades de disciplinas nulifica o potencial da razão, em comunicação ${ }^{134}$. O Século XX é testemunha da barbárie a que conduz a progresso técnico-científico que, encapsulado em culturas de especialistas ${ }^{135}$, perde a referência de outros pontos de vista e dos aspectos sociais e morais que também lhe são inerentes. Permitiu que o homem tomasse em suas mãos "ferramentas de poder incalculável"136, desresponsabilizando-se quanto aos resultados brutais e intoleráveis ${ }^{137}$ de sua aplicação contra o próprio homem.

A cooperação interdisciplinar remete ao diálogo entre as áreas do conhecimento. Ampliando o universo do discurso, possibilita o contato permanente de cada especialidade

\footnotetext{
${ }^{131}$ DEWEY, How we think, 1997, p. 12.

${ }^{132}$ BOUFLEUER, Pedagogia da ação comunicativa, 2001, p. 78.

${ }^{133}$ HABERMAS, Verdade e justificação, 2009, p. 96.

${ }^{134}$ BITTAR, Justiça e emancipação, 2011, p. 77

135 HABERMAS, Consciência moral e agir comunicativo, 2003, p. 33.

${ }^{136}$ DEWEY, The public and its problems, 1991, p. 175.

${ }^{137}$ HOBSBAWN, Era dos extremos, 2000, p. 21.
} 
com o todo e com outras perspectivas e, dessa forma, a permanente crítica e autocrítica revisora do saber produzido.

Tal trânsito "poliglota" dialógico interdisciplinar ${ }^{138}$, recuperador da unidade renegada pela especialização científica moderna, favorece, assim, um hábito de pensar que, diante dos problemas com se defronta na experiência, não prescinde da consideração e interpenetração, em toda a amplitude, das diversas valorações e expressões culturais, interpretações e perspectivas científicas e expectativas morais ${ }^{139}$.

Promove, enfim, na leitura deweyana, o crescimento em geral que, ao se especializar numa dada direção, não prejudica o crescimento em outras direções ${ }^{140}$. Pelo contrário, amplia-as sempre mais, num mundo experiencial cujos horizontes e possibilidades existenciais só podem aumentar.

vi) A participação da sociedade na educação. Pressuposto que a experiência que se pretende educativa demanda a comunicação orientada ao entendimento para se realizar, é patente o risco de fracasso ante o processo de "colonização" da educação pelos sistemas político e econômico (mercado capitalista). Afinal, coordenados pelos meios (e fins) poder e dinheiro, dispensam o entendimento como mecanismo de integração social ${ }^{141}$.

Submetidos às coações sistêmicas, regidas pela racionalidade instrumental, os espaços educacionais e os processos pedagógicos, de um lado, acabam corrompidos em meio para obtenção de lucro, em atividade empresarial, e configurados conforme os valores e práticas mercado. De outro, são submetidos às pressões, demandas e pretensões do poder político ${ }^{142}$.

Nesse contexto, a sociedade civil assume uma participação central na educação. Afinal, pode se distinguir do aparelho governamental sem se confundir com a sociedade empresária. Abrangendo o conjunto de atores sociais que compõem o momento comunicativo precedente ao político-institucional da democracia, habilita-se à promoção e

\footnotetext{
${ }^{138}$ BITTAR, Justiça e liberdade na filosofia do direito de Jürgen Habermas, 2012, p. 258.

139 HABERMAS, Modernidade - um projeto inacabado, 1992, p. 116; HABERMAS, Teoria do agir comunicativo, Tomo 02, p. 590 e 591.

${ }^{140}$ DEWEY, Experiência e educação, 2010, p. 36 e 37.

${ }^{141}$ HABERMAS, Teoria do agir comunicativo, Tomo 02, 2012, p. 354, 556, 597 e 667.

142 BOUFLEUER, Pedagogia da ação comunicativa, 2001, p. 90; HABERMAS, Teoria do agir comunicativo, Tomo 02, 2012, p. 566 e 587.
} 
à experiência de uma forma de interação social solidária e cooperativa, pautada no diálogo, sem ser "tragada pelo Estado e assimilada pela estrutura do mercado"143.

Pode, assim, atuar ativamente não só na prestação educacional, de modo direto, por meio de suas associações e organizações, mas, especialmente, na formulação e na implantação de políticas públicas orientadas em favor da educação - e, portanto, contra a colonização dos processos pedagógicos e sociais, em geral, pela racionalidade sistêmicoinstrumental $^{144}$.

Apoiada em tais diretrizes filosóficas, a tese descortina a educação para a democracia na coerência do processo de ensino-aprendizagem com a experiência democrática: a educação que, discursivamente, autentica os princípios, os conteúdos, as práticas e os procedimentos democráticos, aplicando-os a $\mathrm{si}^{145}$.

Faz-se progressiva e gradualmente na democracia, enquanto práxis dialógica do encontro com o outro, para a solução compartilhada e racional de problemas comuns. Um processo educacional, portanto, em que os sujeitos, desenvolvendo-se cognitiva e moralmente em comunicação, internalizam hábitos de pensar, agir e conviver democráticos, tornando-se capazes de experienciar e enriquecer seu conteúdo em todos os âmbitos da vida social.

Com Dewey e Habermas, o reconhecimento do sentido e do valor racionalcomunicativo e moral cognitivista da democracia permite identificar que a experiência que desenvolve plenamente a pessoa é a mesma que a prepara para o exercício da cidadania. Falar em educação para a democracia remete, enfim, ao atendimento conjungido dos objetivos constitucionalmente atribuídos à educação.

9. Em relação à metodologia de pesquisa e em conformidade com as perspectivas crítica e pragmatista dos referenciais teóricos, a tese vincula, diante do quadro jurídico vigente, a reflexão teórica ao contexto político e educacional brasileiro. E isso, orientando-

\footnotetext{
${ }^{143}$ HABERMAS, A inclusão do outro, 2007, p. 278 e 289; HABERMAS, Direito e democracia, Vol. 02, 2011, p. 22.

144 BOUFLEUER, Pedagogia da ação comunicativa, 2001, p. 96.

${ }^{145}$ KOHLBERG, La Democracia en la escuela secundaria 1992, p. 29.
} 
se ao objetivo prático emancipatório da consolidação da democracia no Brasil, pela via da educação.

Reconhecendo os descaminhos da razão e regressos que acompanharam a história moderna, mas sem renegar a tradição iluminista, recusa a si a condição de teoria sem prática, não se reduzindo, por conseguinte, à postura puramente negativa, antimodernista, que desabilita à ação. Comensurando a medida de nossa impotência, parte do pressuposto que "a existência não esgota as possibilidades da existência e que, portanto, há alternativas susceptíveis de superar o que é criticável no que existe" ${ }^{146}$.

Assim, a pretensão de fundamentar filosoficamente a práxis social implica a assunção do envolvimento e do compromisso ético do pesquisador com a realidade estudada e com o escopo emancipatório que dirige o estudo. Afinal, na pesquisa social, o sujeito do conhecimento, imerso no seu mundo da vida, dentro do qual se movimenta e se comunica, não pode atuar como observador absolutamente neutro e distanciado do objeto estudado. É-lhe inafastável, em suma, a tomada de posições - sujeitas à crítica, à fundamentação e à revisão - como participante do discurso, voltado ao entendimento racional.

Isso, contudo, não frustra a preocupação com método. É pressuposto que interesse e rigor metodológico não constituem atitudes antitéticas e inconciliáveis. E, para tal conciliação, de modo a assegurar racionalidade e cientificidade à tese, são tomados certos cuidados.

A perspectiva pragmatista e o comprometimento com a práxis não são confundidos com a adoção de práticas predominantes na ciência jurídica, das quais a tese, metodologicamente, busca se afastar. São elas:

i) Enfoque dogmático da experiência do direito. É reconhecida a insuficiência da abordagem a posteriori e conservadora inerente à dogmática jurídica, que "toma o direito

${ }^{146}$ SOUSA SANTOS, Boaventura de. Crítica da razão indolente: contra o desperdício da experiência. $7^{\mathrm{a}}$ Ed. São Paulo: Cortez, 2009, p. 23. 
como um dado e procura as condições de sua aplicação"147; que se empenha em lhe conferir sistematicidade e coerência, mas no âmbito de uma abstração lógico-formal.

Desconfia-se, nesse sentido, do distanciamento e da "indiferença controlada" que a ciência dogmática assume em relação ao contexto histórico-social do qual as normas emergem e que determina sua configuração. Pois isso conduz à teorização do direito a partir de uma ilusão funcional da realidade, "imunizando seu próprio saber contra os fatos, em termos de, até certo ponto, poder atuar de modo indiferente em relação a eles"148.

Ao mesmo tempo, rechaça-se o isolamento da ciência, assim operado, dentro da esfera de seu objeto abstrato e "purificado", perdendo de vista, porque supostamente exteriores a ele, "a gênese social dos problemas, as situações reais nas quais a ciência é empregada e os fins perseguidos em sua aplicação"149.

ii) Enfoque "parecer" de pesquisa jurídica. A perspectiva metodológica adotada recusa, ademais, a deturpação de resultados do objeto pesquisado, em vista de interesses e fins velados, que mantém uma relação parasitária e contingente com o contexto comunicativo no qual se desenvolve. Isto é, opõe-se ao uso da linguagem, estrategicamente, como mero instrumento para a obtenção de efeitos perlocucionários ${ }^{150}$.

Rejeita, dessa maneira, a forma-padrão de pesquisa em Direito no Brasil, alcunhada de modelo parecer. Marcada pela confusão entre teoria e prática profissional, segue a lógica da peça e da estratégia advocatícia, selecionando a legislação e o material jurisprudencial e doutrinário unicamente em função da tese defendida, "posta previamente à investigação"151. A argumentação, ora promovida, enfim, não pretende, apenas, "criar a impressão" de que boas razões justificam a conclusão antedada, e não o contrário ${ }^{152}$.

\footnotetext{
${ }^{147}$ FERRAZ JUNIOR, Tércio Sampaio. Introdução ao estudo do direito. Técnica, decisão, dominação. $6^{-}$ed. rev. e amp. São Paulo: Atlas, 2011, p. 57.

${ }^{148}$ FERRAZ JUNIOR, Introdução ao estudo do direito, 2011, p. 88.

149 HORKHEIMER, Max. Teoria tradicional e Teoria Crítica. In HORKHEIMER, Max, BENJAMIN, Walter; ADORNO, Theodor; HABERMAS, Jürgen. Textos Escolhidos. Coleção “Os Pensadores”. Trad. José Lino Grunnewald e outros. 2ª ed. São Paulo: Abril cultural, 1983, p. 125.

${ }^{150}$ HABERMAS, Verdade e justificação, 2009, p. 123; HABERMAS, Teoria do agir comunicativo, Tomo 01, 2012, p. 502 e 503; HABERMAS, Direito e democracia, Vol. 01, 2012, p. 208.

${ }^{151}$ NOBRE, Marcos. Apontamentos sobre a Pesquisa em Direito no Brasil. Novos Estudos. CEBRAP, São Paulo, v. 66, 2003, p. 150.

${ }^{152}$ HABERMAS, Direito e democracia, Vol. 012, 20121, p. 225.
} 
A fim de superar as desvantagens e vícios das referidas práticas e em conformidade com a perspectiva filosófica que assume, a tese aposta no diálogo interdisciplinar e na racionalidade comunicativa, a ele inerente, como caminho metodológico privilegiado para se chegar ao esclarecimento em relação ao seu objeto.

Para isso, rejeitando o isolamento, o distanciamento da experiência social e, assim, o desvirtuamento da pesquisa jurídica, assume a filosofia como forma de conhecimento que pode fazer a mediação não só entre as conclusões das especialidades científicas ${ }^{153}$, mas também entre estas e as experiências, os conflitos, as perspectivas e as possibilidades existenciais, no horizonte do mundo da vida ${ }^{154}$.

Desse modo, a análise filosófica dos institutos da democracia e da educação, orientada e fundamentada no pensamento de Dewey e de Habermas, pretende profundidade e consistência a partir do constante diálogo - crítico e autocrítico do saber produzido - dos autores entre si e com as perspectivas teóricas e empíricas de outros estudiosos e de outras áreas do saber, não só o direito, mas também as ciências sociais, a educação, a história e a psicologia.

Dentro da perspectiva racional comunicativa, ocupa-se, ademais, da apresentação, somente, de relações e conclusões na condição de pretensões de validade, cuja racionalidade remete à aceitabilidade fundamentada do conteúdo que encerra: válido porque, suscetível a crítica, é capaz de fundamentação, com base em razões ${ }^{155}$.

A tese preserva, assim, conforme propugnado por Habermas, uma pretensão cautelosa de unidade e universalidade da razão, cujo lugar é a comunicação orientada ao entendimento. Ao mesmo tempo, voltando a atenção à situação do Brasil atual, adota, com Dewey, o esforço de utilizar a reflexão filosófica e seu instrumental para a compreensão do significado do "curso atual dos acontecimentos", do "detalhe cotidiano", e, dessa forma, para a superação dos problemas sociais e morais concretos e específicos experienciados: um esforço comunicativo, portanto, no sentido de nosso crescimento contínuo e da reconstrução positiva de nossas experiências sociais ${ }^{156}$.

153 SIEBENEICHLER, Jürgen Habermas, 1989, p. 52.

${ }^{154}$ DEWEY, John. The quest for certainty: a study of relation of knowledge and action. New York: Minton, Balch \& Company, 1929, p. 311.

${ }^{155}$ HABERMAS, Teoria do agir comunicativo, Tomo 01, 2012, p. 45.

${ }^{156}$ DEWEY, Reconstruction in philosophy, 2004, p. iii e 123. 
10. A tese é organizada em quatro capítulos.

No Capítulo I - Educação, democracia e modernidade: o contexto brasileiro, é contextualizado o lugar do qual se fala, sob a perspectiva do projeto inacabado da modernidade. A configuração jurídico-constitucional da democracia e dos direitos fundamentais no Brasil - com destaque à educação -, é contraposta ao cenário fático sobre o qual incide, reconstruído historicamente e com o recurso a dados empíricos sobre a realidade nacional. Desse modo, chega-se ao presente de inexperiência democrática, de ineficácia do sistema de direitos, e, por tudo isso, sobrecarregado, pelo passado autoritário, com o desafio da consolidação da democracia no país.

No Capítulo II - Educação e democracia na filosofia social de John Dewey, são apontadas, primeiro, a partir do diagnóstico de modernidade, feito pelo autor, as linhas principais de sua filosofia social pragmatista reconstruída, apreendendo, então, o caráter moderno e crítico de seu pensamento. Na sequência, é dado destaque às teorias deweyanas da experiência, do pensar e do crescimento cognitivo e moral do indivíduo, no processo social contínuo de experiência e reconstrução das experiências. A partir disso, o trabalho pode se debruçar sobre o modelo de democracia do autor, e sobre sua proposta de educação progressiva, ambientada e, ao mesmo tempo, promotora da comunidade democrática.

O Capítulo III - Educação e democracia na filosofia social de Jürgen Habermas segue formato similar ao anterior, dedicando-se, agora, ao pensamento habermasiano. Chega-se ao debate fundamentado sobre a democracia e sobre uma pedagogia da ação comunicativa, abordando-se, previamente, reflexões centrais de sua perspectiva filosófica crítico-revisora do projeto inacabado de modernidade, passando pelas teorias do agir comunicativo, da ética discursiva e do desenvolvimento da consciência moral.

Por fim, o Capítulo IV - Educação para a democracia no Brasil: aproximações entre John Dewey e Jürgen Habermas. Considerando o contexto social contraposto ao quadro jurídico brasileiro, e, assim, ante o desafio, que se enfrenta, da consolidação democrática, são apresentadas as concepções de democracia e de educação para a democracia, configuradas a partir do diálogo entre a filosofia social dos dois autores. 


\section{EDUCAÇÃO, DEMOCRACIA E MODERNIDADE: O CONTEXTO BRASILEIRO}

A reflexão crítica revisora do projeto inacabado de modernidade, em torno da educação para a consolidação da democracia, pressupõe, evidentemente, a contextualização prévia do lugar a partir do qual se fala. Afinal, vem do inconformismo, da indignação diante da realidade brasileira, a qual não anula possibilidades alternativas de existência para si, o impulso crítico para teorizar a sua superação ${ }^{1}$.

Tendo em vista o cumprimento dessa tarefa inicial, o presente capítulo é dedicado à exposição da (in)experiência, no Brasil, da democracia e, em correlação íntima com ela, da cultura de direitos humanos, destacando, nesse ponto, a educação.

\footnotetext{
${ }^{1}$ BAUMAN, Zygmunt. A modernidade líquida. Trad. Plínio Dentzien. Rio de Janeiro: Jorge Zahar, 2001, p. 30; SOUSA SANTOS, Boaventura de. Crítica da razão indolente: contra o desperdício da experiência. $7^{7}$ Ed. São Paulo: Cortez, 2009, p. 23.
} 
Para tanto, começa analisando a configuração jurídico-formal de referidas instituições, na Constituição Federal de 1988, documento que, corporificando a ruptura com o regime militar autoritário (1964 a 1985), apresenta um duplo valor simbólico: "é o marco jurídico da transição democrática, bem como da institucionalização dos direitos humanos no país"2.

O texto constitucional, nesse sentido, integra linhas mestras do projeto de modernidade, em sua perspectiva de emancipação da humanidade, por meio do saber, da razão - o esclarecimento -, de modo a livrá-la da menoridade manifestada na subserviência à natureza e aos outros homens ${ }^{3}$; e possibilitar-lhe, no âmbito do Estado de Direito, a participação em pé de igualdade na formação do acordo racional, em que pode se apoiar a legitimidade da comunidade jurídica ${ }^{4}$. Em Kant, um cenário no qual o aspecto da coerção, intrínseco ao direito, explica-se na sua relação com a liberdade: limita-se a liberdade de cada um a fim de assegurar a liberdade de todos ${ }^{5}$.

Na sequência, o contexto sobre o qual se afirma, no plano jurídico do dever ser, a ordem constitucional, é reconstruído, primeiro, sob uma perspectiva histórica. Retomam-se os períodos constitucionais pelos quais o Brasil passou até chegar na sua configuração atual, para demonstrar como o país "nasceu e cresceu dentro de condições negativas à experiência democrática" ${ }^{\circ}$. Conformou uma tradição política autoritária, com fortes traços patrimonialistas e paternalistas, habituada muito mais à usurpação do poder pelo golpe e à manipulação instrumental do conceito de democracia do que ao convencimento e entendimento por meio do diálogo ${ }^{7}$. Uma história, em suma,

(...) em que política tem sido, quase sempre, o privilégio de uns quantos oligarcas e assemelhados. Uma história que, até aqui, mal conseguiu constituir um espaço público onde a atividade política, quase sempre

\footnotetext{
${ }^{2}$ PIOVESAN, Flávia. Temas de direitos humanos. 2ª ed. rev. ampl. e atual. São Paulo: Max Limonad, 2003, p. 328.

${ }^{3}$ ADORNO, Theodor W.; HORKHEIMER, Max. Dialética do Esclarecimento. Trad. Guido Antonio de Almeida. Rio de Janeiro: Jorge Zahar, 1985, p. 17; KANT, Emmanuel. Resposta à pergunta: que é o iluminismo? In A paz perpétua e outros opúsculos. Trad. Artur Morão. Edições 70: Lisboa, 2004, p. 11; BITTAR, Eduardo C. B. Justiça e emancipação: reflexões jusfilosóficas a partir do pensamento de Jürgen Habermas. Tese apresentada em concurso de Professor Titular junto ao Departamento de Filosofia e Teoria Geral do Direito da Faculdade de Direito da Universidade de São Paulo. São Paulo, 2011, p. 108 e 109.

${ }^{4}$ HONNETH, Axel. Luta por Reconhecimento. A gramática moral dos conflitos sociais. 2 ${ }^{-}$ed. São Paulo: Editora 34, 2009, p. 188.

${ }^{5}$ HABERMAS, Jürgen Direito e democracia: entre factibilidade e validade. Volume 01. 2a ed. Trad. Flávio Beno Siebeneichler. Rio de Janeiro: Tempo Brasileiro, 2012, p. 49, 50 e 126.

${ }^{6}$ FREIRE, Paulo. Educação como prática de liberdade. 14ª Ed. Rio de Janeiro: Paz e Terra, 2011, p. 90.

${ }^{7}$ WEFFORT, Francisco C. Por que democracia? 2a Ed. São Paulo: Brasiliense, 1984, p. 34.40 e 46.
} 
limitada às classes dominantes, pudesse se diferenciar das atividades privadas dessas mesmas classes ${ }^{8}$.

Enfim, pressuposto que a "realidade brasileira possui a sua própria demarcação histórica como causa determinante de suas clivagens", um retrato pormenorizado desta mesma realidade passa, necessariamente, "pelo estudo e pela reconstituição dos traços históricos que demarcam a vivência política brasileira como uma experiência incipiente"9.

A partir disso, chega-se, de modo mais adequado, ao presente de inexperiência democrática e de déficits de direitos humanos, em todas as suas dimensões. Legados do passado antirrepublicano e antidemocrático, não se dissipam só com a promulgação da nova ordem política ${ }^{10}$. Afinal, se a conquista do Estado de Direito, depois de vinte anos da “desgraça militar" é, por si só, um feito de inquestionável significação, é "evidente que o fim da ditadura não significou a consolidação da democracia nem a eliminação de violações dos direitos humanos da maioria dos brasileiros" ${ }^{\prime 1}$.

Nesse ponto, o recurso aos dados empíricos e estatísticos sobre a realidade nacional é utilizado como importante estratégia metodológica complementar ${ }^{12}$.

Dessa forma, o capítulo pretende abordar a (falta de) qualidade da democracia brasileira, que justifica o empenho teórico crítico para sua superação. Uma experiência ante a qual não chegou inesperada, na esfera pública, a provocadora indagação Por que o Brasil não tem indignados?, que dá título a artigo publicado pelo jornal espanhol El Pais, tratando de uma afirmada apatia nacional frente a escândalos de corrupção, divulgados pela imprensa brasileira em 2011 ${ }^{13}$. E mais, uma vivência em que é razoável, nos preparativos das eleições municipais ocorridas um ano mais tarde, a campanha promovida pelo Tribunal Superior Eleitoral, para que o eleitorado votasse "limpo". Valia-se da imagem de um mecânico que, enquanto limpava a mão de graxa, refletia: “Tem gente que pensa que todo político é igual, que todos são sujos. Eu penso diferente. Tem muito

\footnotetext{
${ }^{8}$ WEFFORT, Por que democracia?, 1984, p. 25.

${ }^{9}$ BITTAR, Eduardo C. B. O direito na pós-modernidade (e reflexões frankfurtianas). $2^{2}$ ed. rev., atual. e amp. Rio de Janeiro: Forense Universitária, 2009, p. 215 e 216.

${ }^{10}$ MOISÉS, José Álvaro. Os brasileiros e a democracia. Bases sócio-políticas da legitimidade democrática. São Paulo: Ática, 1995, p. 27.

${ }^{11}$ BENEVIDES, Maria Victoria de Mesquita. Em defesa da república e da democracia. In BENEVIDES, Maria Victoria de Mesquita; BERCOVICI, Gilberto; MELO, Claudinei de. Direitos humanos, democracia e república: homenagem a Fábio Konder Comparato. São Paulo: Quartier Latin, 2009, p. 727.

${ }^{12}$ DEMO, Pedro. Cidadania menor. Algumas indicações quantitativas de nossa pobreza política. Petrópolis: Vozes, 1992, p. 07, 12 e 13.

13 ARIAS, Juan. ¿Por qué Brasil no tiene indignados? Jornal El Pais, 07/07/2011. Disponível em: http://internacional.elpais.com/internacional/2011/07/07/actualidad/1309989609_850215.html. Acesso em $02 / 08 / 2012$.
} 
candidato bem intencionado"14. Em 2014, campanha do mesmo Tribunal, em vista das eleições nos níveis estaduais e federal, dizia aos eleitores: "vem pra urna" "15, num apelo "um tanto frenético" para a conscientização quanto a seus direitos e obrigações, ao qual Dewey já fazia referência no contexto norte-americano da primeira metade do século $\mathrm{XX}^{16}$.

Nessa abordagem, a experiência da democracia, em que pese imperfeita, é compreendida como um processo de aprendizagem e de consolidação e fortalecimento de seus mecanismos e procedimentos, com todas as contradições, avanços e retrocessos que implica. Não se pretende, portanto, de forma nenhuma, identificar, como dado antropológico do brasileiro, feito uma segunda natureza irreversível, a apatia e a pobreza política. Afinal, isso contrariaria o enfoque experiencial e social de constituição do indivíduo, a que se filiam John Dewey e Jürgen Habermas. Mas não só. Exigiria, também, negar a "feia verdade" da história do país, apresentada por Darcy Ribeiro, que afasta a caracterização do povo brasileiro como essencialmente cordial, "por excelência gentil e pacífico". Tratou-se, de fato, de uma caminhada altamente conflituosa, dilacerada por conflitos de toda ordem (étnicos, sociais, econômicos, religiosos, raciais, etc.), podendo-se "afirmar, mesmo, que vivemos praticamente um estado de guerra latente, que, por vezes, e com frequência, se torna cruento, sangrento" ${ }^{\prime 17}$.

Eis o ponto de partida da tese: o presente de inexperiência democrática sobrecarregado, pelo passado, de tarefas democratizantes. Um contexto que resulta de um percurso histórico - tal como a própria modernidade - drasticamente inacabado ${ }^{18}$ e, nesse sentido, marcado pela "sensação desconfortável de incompletude", em relação à construção da cidadania no país ${ }^{19}$. É diante dele que se coloca o desafio da consolidação da democracia, a partir da educação para (e na) sua experiência.

14 BRASIL. TRIBUNAL SUPERIOR ELEITORAL. Campanha Eleições 2012. Pesquise o passado do candidato. 2012. Disponível em: http://www.tse.jus.br/hotSites/voto-limpo/\#prettyPhoto. Acesso em 03/10/2012.

${ }^{15}$ Informações sobre a campanha disponíveis no site oficial do Tribunal Superior Eleitoral: $\underline{\text { www.tse.gov.br. }}$ Acesso em 18/09/2014.

${ }^{16}$ DEWEY, John. The public and its problems. Swallow Press/Ohio University Press/Athens, 1991, p. 117 e 118.

${ }^{17}$ RIBEIRO, Darcy. O povo brasileiro. São Paulo: Cia das Letras, 2006, p. 152 e 153.

${ }^{18}$ MOTA, Carlos Guilherme. Viagem incompleta. A experiência brasileira. Formação: histórias. 3a ed. São Paulo: Editora SENAC, 2009, p. 23.

${ }^{19}$ CARVALHO, José Murilo. Cidadania no Brasil: o longo caminho. 13ª Ed. Rio de Janeiro: Civilização brasileira, 2010, p. 219. 


\section{Democracia, direitos humanos e educação no ordenamento jurídico-constitucional brasileiro}

1.1. A Constituição Federal de 1988, como referido, representa o marco fundamental da afirmação, no Brasil, após duas décadas de ditadura, da democracia e, ao mesmo tempo, dos direitos humanos ${ }^{20}$.

Incorpora e institucionaliza, no nível constitucional, a assunção pela sociedade civil do discurso de defesa dos direitos humanos e da democracia, usurpado contraditória e cinicamente pelo regime militar e feito fonte justificadora do golpe de Estado de $1964^{21}$.

Nesse sentido, logo no Art. $1^{\underline{0}}$, constitui a República Federativa do Brasil como um Estado Democrático de Direito apresentando, como fundamentos em que é alicerçado, a soberania, a cidadania, a dignidade da pessoa humana, os valores sociais do trabalho e da livre iniciativa e o pluralismo político.

Detalhado ao longo do texto constitucional e amparado em robusto sistema de direitos fundamentais, o dispositivo inaugural projeta um Estado de Direito que protege o indivíduo em suas facetas de pessoa humana, com autonomia individual, de cidadão na esfera política, e, na esfera econômica, de trabalhador; consagra a economia capitalista; e resguarda a pluralidade do jogo político.

Não promete a transição para o socialismo $^{22}$. Mas, também, não se restringe à definição de um modelo liberal de Estado: um mero aparelho da administração, minimalista, que atua, limitadamente, na normatização jurídico-estatal da sociedade econômica individualista - estruturada segundo as leis do mercado -, de modo a assegurar o bem comum apolítico, que não diz mais do que a "satisfação das expectativas de felicidade das pessoas privadas em condições de produzir" ${ }^{\prime 23}$.

O Estado Democrático de Direito, configurado pela Constituição, à luz das conquistas históricas da modernidade, incorpora tanto elementos do Estado Liberal

\footnotetext{
${ }^{20}$ PIOVESAN, Temas de direitos humanos, 2003, p. 328.

${ }^{21}$ WEFFORT, Por que democracia?, 1984, p. 33; VIOLA, Sólon Eduardo Annes. Direitos humanos no Brasil: abrindo portas sob neblina. In SILVEIRA, Rosa Maria Godoy e outros (org.). Educação em direitos humanos: Fundamentos teórico-metodológicos. João Pessoa: Editora Universitária, 2007, p. 127.

22 SILVA, José Afonso da. Curso de direito constitucional positivo. 33aㅡ ed. rev. e atual. São Paulo: Malheiros, 2010, p. 120.

${ }^{23}$ HABERMAS, Jürgen. A inclusão do outro. Estudos de teoria política. Trad. George Sperber, Paulo Astor Soethe e Milton Camargo Mota. 3ª ed. São Paulo: Loyola, 2007, p. 278 e 288.
} 
burguês - submetido ao império da lei e garantidor dos direitos individuais ainda que num plano meramente formal - como, suplantando-o, do Estado Social. Traz, também, por conseguinte, extenso rol de direitos sociais, econômicos e culturais, de cunho prestacional, a serviço da igualdade e liberdade material $^{24}$.

E tudo isso, na democracia. Para além da mera junção dos dois citados modelos históricos de Estado de Direito, supera-os, atribuindo à organização estatal, como adjetivação principal, nem o abstencionismo liberal, nem o paternalismo social, mas a forma democrática, a irradiar os valores, práticas e procedimentos que lhe são próprios não só sobre o sistema político-governamental, como também sobre os demais espaços e momentos sociais que o precedem e o envolvem ${ }^{25}$.

É com essa configuração que a Constituição resguarda, no plano jurídico-formal, um de seus pontos mais essenciais e positivos: a prioridade dada à pessoa humana ${ }^{26}$. Conforme a tradição do iluminismo, recuperada pelo Direito Internacional dos Direitos Humanos $^{27}$, toma o homem como valor-fonte de toda experiência jurídica ${ }^{28}$. Na apresentação de Kant, a concepção do ser humano como um valor absoluto, um fim em si mesmo, expressa no princípio prático supremo: "Age de tal maneira que uses a humanidade, tanto na tua pessoa como na pessoa de qualquer outro, sempre e simultaneamente como fim e nunca simplesmente como meio" 29 .

Nesse sentido, entre os fundamentos do Estado brasileiro, enumerados no Art. $1^{\underline{o}}$, a dignidade humana sobressai como princípio basilar e estruturante que, juntamente com os direitos fundamentais - exigências e explicitações dessa mesma dignidade -, confere unidade de sentido a todo ordenamento jurídico-constitucional. Corresponde ao critério axiológico fundamental para sua interpretação e compreensão ${ }^{30}$, “ombreando em

\footnotetext{
${ }^{24}$ SILVA, Curso de direito constitucional positivo, 2010, p. 115 e 119; SARLET, Ingo W. Dignidade da pessoa humana e direitos fundamentais na Constituição Federal de 1988. Porto Alegre: Livraria do advogado, 2011, p. 110.

${ }^{25}$ SILVA, Curso de direito constitucional positivo, 2010, p. 110; BONAVIDES, Paulo. Do Estado Liberal ao Estado Social. 10ª ed. São Paulo: Malheiros, 2011, p. 203 e 204.

${ }^{26}$ DALLARI, Dalmo de Abreu. Educação e preparação para a cidadania. In BENEVIDES, Maria Victoria de Mesquita; BERCOVICI, Gilberto; MELO, Claudinei de. Direitos humanos, democracia e república: homenagem a Fábio Konder Comparato. São Paulo: Quartier Latin, 2009, p. 325.

27 PIOVESAN, Flávia. Direitos humanos e o direito constitucional internacional. $13^{\mathrm{a}}$ ed. rev. e atual. São Paulo: Saraiva, 2012, p. 183 e 184.

${ }^{28}$ LAFER, Celso. A reconstrução dos direitos humanos: um diálogo com o pensamento de Hannah Arendt. São Paulo: Cia das Letras, 1988, p. 15 e 19.

${ }^{29}$ KANT, Emmanuel. Fundamentação da metafísica dos costumes. Lisboa: Edições 70, 2008, p. 71 a 73.

${ }^{30}$ PIOVESAN, Temas de direitos humanos, 2003, p. 339; SARLET, Dignidade da pessoa humana e direitos fundamentais na Constituição Federal de 1988, 2011, p. 91, 93, 95 e 101.
} 
importância talvez apenas com a vida - e mesmo esta há de ser vivida com dignidade". Induzindo ao conceito da pessoa como "fundamento e fim da sociedade e do Estado", faz da Constituição de 1988 "pelo menos de acordo com seu texto (...) uma Constituição da pessoa humana, por excelência" ${ }^{31}$.

Formata-se, enfim, um Estado que, a despeito da opção pelo capitalismo - e da contradição que isso implica diante da abertura à empresa cujo fim, sendo o lucro, não é a pessoa -, distingue-se pela dinâmica democrática. E se volta, precipuamente, à garantia da dignidade humana, num cenário social, de justiça e bem-estar. Exige, por isso, como pressuposto e resultado da experiência da democracia, o reconhecimento e a proteção dos direitos fundamentais de todas as dimensões ${ }^{32}$.

A democracia, em última análise, aparece como consequência organizatória e, ao mesmo tempo, garantia constitucional essencial de uma existência digna que se atualiza no respeito aos direitos fundamentais ${ }^{33}$.

1.2. Assim configurada, a ordem constitucional brasileira resguarda duas ideias fundamentais ao direito moderno, sob o enfoque de uma legitimidade que - como destaca Jürgen Habermas -, no cenário pós-metafísico, "destituído das certezas coletivas da religião e da metafísica”, há de se configurar através da legalidade democrática. São elas: a soberania popular e os direitos humanos ${ }^{34}$.

Quanto ao princípio da soberania popular, referido à origem e ao exercício do poder soberano pelo povo ${ }^{35}$, é afirmado já no Art. $1^{\underline{o}}$, parágrafo único, da Constituição de 1988. Prevê: "Todo o poder emana do povo, que o exerce por meio de representantes eleitos ou diretamente, nos termos desta Constituição".

${ }^{31}$ SARLET, Dignidade da pessoa humana e direitos fundamentais na Constituição Federal de 1988, 2011, p. 91,92 e 99.

32 PIOVESAN, Temas de Direitos Humanos, 2003, p. 333; SARLET, Dignidade da pessoa humana $e$ direitos fundamentais na Constituição Federal de 1988, 2011, p. 101.

${ }^{33}$ HÄBERLE, Peter. El estado constitucional. Trad. Héctor Fix-Fierro. México: UNAM, 2003, p. 193.

${ }^{34}$ HABERMAS, Direito e democracia, Vol. 01, 2012, p. 133; HABERMAS, Jürgen. Direito e democracia: entre factibilidade e validade. Volume 02. 1를 Ed. Trad. Flávio Beno Siebeneichler. Rio de Janeiro: Tempo Brasileiro, 2011, p. 214.

${ }^{35}$ DALLARI, Dalmo de Abreu. Elementos de teoria geral do estado. 29ª ed. atual. São Paulo: Saraiva, 2010, p. 82. 
O texto rompe, dessa maneira, com a tradição constitucional brasileira que, desde 1934, restringia a democracia ao modelo representativo, em que Todo poder emana do povo e em seu nome é exercido.

Estabelece, em seu lugar, o regime democrático semidireto que combina a representação - com a eleição periódica de representantes dos Poderes Executivo e Legislativo - e mecanismos de participação direta no governo. Valoriza, desse modo, a complementaridade entre as duas formas de experiência democrática, afastando, assim, a tradicional oposição, falso dilema, de tomar qualquer uma delas como excludente ${ }^{36}$.

1.3. Na sequência do dispositivo inaugural, ainda no Título $I$, a Constituição, corroborando seu traço moderno, traz, no Art. $2^{\circ}$, o princípio, básico do Estado de Direito, da separação dos poderes; no Art. $3^{\circ}$, enumera os objetivos fundamentais da República: construção de uma sociedade livre, justa, solidária; garantia do desenvolvimento nacional; erradicação da pobreza e da marginalização; redução das desigualdades sociais e regionais; e promoção do bem de todos, sem preconceitos e discriminações; e, finalmente, no Art. $4^{\underline{0}}$, na linha do ideal kantiano de paz perpétua, com o exercício pacífico do poder soberano pelos $\operatorname{Estados}^{37}$, relaciona os princípios que devem reger o país nas relações internacionais: a independência nacional; a preeminência dos direitos humanos; a autodeterminação dos povos; a não-intervenção; a igualdade entre os Estados; a defesa da paz; a solução pacífica de conflitos; o repúdio ao terrorismo; a cooperação entre os povos para o progresso da humanidade; a concessão de asilo político; e a integração regional.

Passa, então, agora no Título II, a tratar especificamente dos direitos fundamentais.

Alargando significativamente a extensão desses direitos e incorporando os resultados de sua afirmação histórica, na modernidade ${ }^{38}$, a Carta de 1988 coloca-se entre as mais avançadas do mundo nessa matéria ${ }^{39}$.

\footnotetext{
${ }^{36}$ WEFFORT, Por que democracia?, 1984, p. 121; BENEVIDES, Maria Victoria de Mesquita. A cidadania ativa: Referendo, plebiscito e iniciativa popular. 3를 ed. São Paulo: Ática, 2003, p. 15.

${ }^{37}$ KANT, Emmanuel. A Paz Perpétua: um projeto Filosófico. In A Paz Perpétua e Outros Opúsculos. Trad. Artur Morão. Lisboa/Portugal:Edições 70, 1990; BOBBIO, Norberto. Direito e Estado no Pensamento de Emmanuel Kant. 3ª ed. Brasília: Editora UNB, 1995, p. 158.

${ }^{38}$ COMPARATO, Fábio Konder. A afirmação histórica dos direitos humanos. 8ª ed. São Paulo: Saraiva, 2013, p. 64 a 67.

${ }^{39}$ PIOVESAN, Direitos humanos e o direito constitucional internacional, 2012, p. 81 e 82.
} 
Inscreve, no ordenamento jurídico brasileiro, de forma consistente, todas as três dimensões dos direitos fundamentais: os direitos civis e políticos, de cunho liberal e fortemente individualista; os direitos sociais, econômicos e culturais próprio aos Estados Sociais; e os direitos, de titularidade transindividual, de fraternidade e solidariedade ${ }^{40}$. Abrange, nesse sentido, todas as cinco categorias de direito fundamentais, sugeridas por Habermas, à luz da teoria do discurso ${ }^{41}$.

Primeiro, no Art. 5ำ, estabelece extenso rol de direitos individuais, definidores do campo próprio, privado, de ação livre do indivíduo, assim reconhecido juridicamente pelo Estado e pelos demais membros da sociedade.

O dispositivo começa com a afirmação dos invioláveis direitos à vida, à liberdade, à igualdade, à segurança e à propriedade, complementados e especificados, na sequência, em setenta e oito incisos, que preveem, dentre outras normas: o princípio da legalidade; a proibição de tortura e de tratamento desumano; a liberdade de consciência, de crença e de manifestação e expressão do pensamento e da atividade intelectual; o direito à vida privada, à intimidade, à imagem e à honra; a inviolabilidade do asilo da casa e do sigilo da comunicação; a liberdade de locomoção; a liberdade de exercício do trabalho; o respeito ao direito adquirido, ao ato jurídico perfeito e à coisa julgada; e princípios de direito penal como a irretroatividade da lei mais severa e a individualização da pena. Trata-se, na definição habermasiana, dos direitos a iguais liberdades subjetivas, isto é, "direitos fundamentais que resultam da configuração politicamente autônoma do direito à maior medida possível de iguais liberdades subjetivas de ação" ${ }^{, 42}$.

Traz, também, vigoroso rol de prerrogativas processuais - incluindo o direito de ação, a ampla defesa e o devido processo legal - as quais, na classificação habermasiana, estão inseridas na categoria das garantias do caminho do direito: "direitos fundamentais

40 SARLET, Ingo Wolfgang e outros. Curso de direito constitucional. $2^{\mathrm{a}}$ ed. rev., atual. e amp. São Paulo: RT, 2013, p. 272-274.

${ }^{41}$ HABERMAS, Direito e democracia, vol. 01, 2012, p. 158 a 160.

${ }^{42}$ HABERMAS, Direito e democracia, vol. 01, 2012, p. 121 e 159; FERRAZ JUNIOR. Tércio Sampaio. Responsabilidade sem culpa, culpa sem responsabilidade na sociedade tecnológica. In FABIANI, Emerson Ribeiro (org.). Impasses e aporias do direito contemporâneo. Estudos em homenagem a José Eduardo Faria. São Paulo, Saraiva, 2011, p. 137. 
que resultam imediatamente da possibilidade de postulação judicial de direitos e da configuração politicamente autônoma da proteção jurídica individual”43.

No Art. 12, são previstos os direitos fundamentais de nacionalidade, intitulados, com Habermas, como direitos à associação e por ele definidos como "direitos fundamentais que resultam da configuração politicamente autônoma do status de um membro numa associação voluntária de parceiros do direito". Correspondem, em suma, aos direitos de pertença à comunidade organizada na forma do Estado ${ }^{44}$.

Como os direitos fundamentais processuais acima referidos, são, para o filósofo frankfurtiano, correlatos necessários dos direitos a iguais liberdades subjetivas de ação. Somadas, essas três categorias resguardam, no texto constitucional, a base que garante a autonomia privada dos sujeitos de direito, na medida em que se reconhecem intersubjetivamente no papel de destinatários da ordem jurídica. Instituem, destarte, "um status que lhes possibilita a pretensão de obter direitos e de fazê-los valer reciprocamente ${ }^{, 45}$.

É, contudo, com os direitos políticos que os sujeitos de direito dão um passo além e "assumem também o papel de autores de sua ordem jurídica". São os "direitos fundamentais à participação, em igualdade de chances, em processos de formação de opinião e da vontade, nos quais os civis exercitam a sua autonomia política e através dos quais eles criam direito legítimo"

Estão previstos no Art. 14, o qual apresenta os "termos", por meio dos quais a soberania popular é exercida, conforme indicado no Art. $1^{\circ}$, parágrafo único, do texto constitucional.

A primeira parte do caput prevê esse exercício "pelo sufrágio universal e pelo voto direto e secreto, com igual valor para todos". Dá o tom, assim, em primeiro lugar, da democracia representativa, retomado nos parágrafos, restritos ao tratamento de questões

\footnotetext{
${ }^{43}$ HABERMAS, Direito e Democracia, vol. 01, 2012, p. 159.

${ }^{44}$ HABERMAS, Direito e Democracia, vol. 01, 2012, p. 159 e 161.

${ }^{45}$ HABERMAS, Direito e Democracia, vol. 01, 2012, p. 159.

${ }^{46}$ HABERMAS, Direito e democracia, vol. 01, 2012, p. 159.
} 
eleitorais como o alistamento e a elegibilidade, no âmbito das eleições para cargos nos Poderes Executivo e Legislativo.

Já a parte final estabelece, como instrumentos de participação direta, "nos termos da lei”, o plebiscito, o referendo e a iniciativa popular ${ }^{47}$. Os dois primeiros institutos mencionados são definidos, no Art. $2^{\underline{o}}$ da Lei no 9.709/1998, como “consultas formuladas ao povo para que delibere sobre matéria de acentuada relevância, de natureza constitucional, legislativa ou administrativa", sendo o plebiscito "convocado com anterioridade a ato legislativo ou administrativo, cabendo ao povo, pelo voto, aprovar ou denegar o que lhe tenha sido submetido" e o referendo "convocado com posterioridade a ato legislativo ou administrativo, cumprindo ao povo a respectiva ratificação ou rejeição". Quanto à iniciativa popular de projetos de lei, no âmbito federal, está definida no Art. 61, $\S 2^{\underline{\mathrm{o}} 48}$.

Desse modo, ao tratar da participação política, no Art. 14, a Constituição limita-se, no campo da representação, à normatização básica do instituto do voto e dos direitos de votar e ser votado, referindo-se, ainda, aos três citados "mecanismos institucionais de participação popular na atividade legislativa e na definição de políticas governamentais" "49.

Isso não exclui, absolutamente, outras formas de experiência da democracia, nas esferas da sociedade civil, da estrutura governamental que compõe o sistema político e da relação entre ambas. Nesse sentido, o país deu passo importante ao elevar, conforme previsto no Decreto Federal n⿳0 8.243/2014, a participação social ao nível de "método de governo" (Art. 4 $4^{\underline{o}}$, inciso I). O regulamento citado estabelece a Política Nacional de Participação Social, "com o objetivo de fortalecer e articular os mecanismos e as instâncias democráticas de diálogo e a atuação conjunta entre a administração pública federal e a sociedade civil" (Art. $1^{\underline{o}}$ ). E reconhece, como ambientes e instrumentos para sua efetivação, "sem prejuízo da criação e do reconhecimento de outras formas de diálogo", os conselhos e as comissões de políticas públicas, a ouvidoria pública, as audiências e consultas públicas; e o ambiente virtual de participação social (Art. $6^{\circ}$ ).

\footnotetext{
${ }^{47}$ Dalmo de Abreu Dallari faz a ressalva de que tais instrumentos "não dão ao povo a possibilidade de ampla discussão antes da deliberação, sendo por isso classificados pela maioria como representativos da democracia semidireta" (DALLARI, Elementos de teoria geral do estado, 2010, p. 153).

48 “Art. 61. (...) $\S 2^{\underline{\mathrm{o}}} \mathrm{A}$ iniciativa popular pode ser exercida pela apresentação à Câmara dos Deputados de projeto de lei subscrito por, no mínimo, um por cento do eleitorado nacional, distribuído pelo menos por cinco Estados, com não menos de três décimos por cento dos eleitores de cada um deles".

${ }^{49}$ BENEVIDES, A cidadania ativa, 2003, p. 17.
} 
A democracia, afirmada no texto constitucional como adjetivo principal do Estado brasileiro, projeta - pelo menos, possibilita - uma cidadania que vai além dos procedimentos institucionalizados constitucionalmente. Permite fazer da experiência democrática um processo criativo, uma caminhada, em que são construídos e reconstruídos novos e múltiplos mecanismos e espaços de participação política, direta e indireta $^{50}$.

Por fim, ainda no Título II, são relacionados os direitos sociais. O Art. $6^{0}$ abrange, nessa categoria, "a educação, a saúde, a alimentação, o trabalho, a moradia, o lazer, a segurança, a previdência social, a proteção à maternidade e à infância, a assistência aos desamparados". Do Art. $7^{\underline{0}}$ ao Art. 11 é detalhada a proteção do trabalho e do trabalhador, em abrangendo rol de direitos e liberdades sociais ${ }^{51}$, como a fixação da jornada máxima de trabalho normal e a remuneração superior da jornada extraordinária; a garantia, a irredutibilidade e a proteção do salário, nunca inferior ao salário mínimo capaz de atender as necessidades vitais básicas do trabalhador e de sua família; a proteção contra despedida arbitrária; o repouso semanal remunerado; as férias; a liberdade de associação sindical; o direito de greve, dentre tantos outros.

Ademais, esparsos ao longo do texto constitucional, é de se observar outros direitos fundamentais da segunda e, também, da terceira dimensão. Dentre eles, o direito à cultura e à preservação, valorização e acesso às manifestações e ao patrimônio cultural brasileiro (Art. 215); o direito ao desporto e ao lazer (Art. 217), o direito ao desenvolvimento, à pesquisa e à capacitação científica e tecnológica (Art. 218) e o direito ao meio ambiente ecologicamente equilibrado (Art. 225).

Todos eles somados tornam presente, no ordenamento constitucional, a quinta categoria, referida por Habermas - implicação necessária das anteriores -, dos direitos fundamentais a condições de vida garantidas social, técnica e ambientalmente. E isso, na medida em que necessários para o aproveitamento, em igualdade de condições, dos direitos abrangidos nas outras quatro categorias ${ }^{52}$.

50 BENEVIDES, A cidadania ativa, 2003, p. 18 e 19; BENEVIDES, Em defesa da república e da democracia, 2009, p. 727.

${ }^{51}$ SARLET e outros, Curso de direito constitucional, 2013, p. 274.

${ }^{52}$ HABERMAS, Direito e democracia, vol. 01, 2012, p. 160. 
1.4. Reconhecida, no Art. $6^{\circ}$, como direito fundamental social, a educação é regulamentada, de modo detalhado, em Seção específica que inicia, no Título VIII - Da Ordem Social da Constituição, o Capítulo III - Da Educação, Da Cultura e Do Desporto.

Começa com o Art. 205, bastante ambicioso em relação à matéria: “A educação, direito de todos e dever do Estado e da família, será promovida e incentivada com a colaboração da sociedade, visando ao pleno desenvolvimento da pessoa, seu preparo para o exercício da cidadania e sua qualificação para o trabalho".

A partir dele, complementado e detalhado nos dispositivos subsequentes e na legislação infraconstitucional que os regulamenta, é possível traçar um panorama geral, mas bastante adequado, da configuração jurídica da educação no Brasil.

Em primeiro lugar, é importante reconhecer o sentido ampliado conferido ao termo educação no dispositivo transcrito. Não se reduz, absolutamente, ao processo de ensinoaprendizagem nas instituições escolares ${ }^{53}$.

Não podia ser diferente. A vida constitui um tecido inesgotável de experiências e reconstrução de experiências, em comunicação. A individualidade emerge, faz-se e se renova em relação com o outro, dentro de um continuum experiencial em que o sujeito modifica e é modificado pelo ambiente social. A vida social constitui, em si, aprendizagem. Vida, experiência, comunicação e educação não se separam ${ }^{54}$.

Esse conceito abrangente de educação, colado à experiência social, em seu mais amplo sentido, está previsto logo no Art. $1^{\underline{0}}$ da Lei de Diretrizes e Bases da Educação Nacional ( $\mathrm{n}^{\underline{0}}$ 9.394/1996). Define-a como todos aqueles os processos formativos desenvolvidos na vida familiar, na convivência humana, no trabalho, nos movimentos sociais e organizações da sociedade civil, nas manifestações culturais e, também, nas instituições de ensino e pesquisa. O ordenamento jurídico brasileiro reconhece, desse modo, que:

${ }^{53}$ SAVIANI, Dermeval. A nova lei da educação: trajetória, limite e perspectivas. $9^{\mathfrak{a}}$ ed. Campinas: Autores Associados, 2004, p. 03.

${ }^{54}$ TEIXEIRA, Anísio S. A pedagogia de Dewey (Esboço da teoria de educação de John Dewey). In DEWEY, John. Experiência e natureza; Lógica: a teoria da investigação; A arte como experiência; Vida e educação; Teoria da vida moral. Trad. Murilo Otávio Rodrigues Paes Leme, Anísio S. Teixeira e Leônidas Gontijo de Carvalho. Coleção Os Pensadores. São Paulo: Abril Cultural, 1980, p. 113, 115; MEAD, George Herbert. Mind, self and society: from the standpoint of a social behaviorist. Edited and with an introduction by Charles W. Morris. Chicago/London: University of Chicago Press, 1992, p. 164. 
A humanidade vive em permanente processo de reflexão e aprendizado. Esse processo ocorre em todas as dimensões da vida, pois a aquisição e produção de conhecimento não acontecem somente nas escolas e instituições de ensino superior, mas nas moradias e locais de trabalho, nas cidades e no campo, nas famílias, nos movimentos sociais, nas associações civis, nas organizações não-governamentais e em todas as áreas da convivência humana ${ }^{55}$.

O referido dispositivo inaugural, todavia, em seu $\S 1^{\underline{0}}$, restringe o escopo da lei à regulamentação, somente, da "educação escolar, que se desenvolve, predominantemente, por meio do ensino, em instituições próprias”. E, nesse ponto, distingue, sem negar nenhuma delas, duas esferas específicas do gênero educação: a escolar ou formal e a nãoformal.

A primeira tem lugar na escola, espaço institucional privilegiado e especialmente voltado à transmissão formal e sistematizada da tradição cultural do grupo social, de seus conhecimentos, valores, hábitos e atitudes.

De acordo com o Art. 21 da Lei de Diretrizes e Bases, é dividida em: i) educação básica, composta pela educação infantil, em creches para crianças até os três anos de idade, e em pré-escolas, para as crianças de quatro e cinco anos (Art. 30); o ensino fundamental, com nove anos de duração, iniciando-se aos seis anos de idade (Art. 32); e o ensino médio, com duração de três anos (Art. 35); e ii) educação superior, em que se destacam os cursos de graduação e os cursos e programas de pós-graduação (Art. 44).

Integradas a tais níveis educacionais, a Lei de Diretrizes e Bases prevê, ainda, a educação de jovens e adultos "destinada àqueles que não tiveram acesso ou continuidade de estudos no ensino fundamental e médio na idade própria" (Art. 37); a educação profissional e tecnológica, orientada ao mundo do trabalho (Art. 39); e a educação especial "oferecida preferencialmente na rede regular de ensino, para educandos com deficiência, transtornos globais do desenvolvimento e altas habilidades ou superdotação" (Art. 58).

Mas, se é na educação formal que o "saber aparece sistematizado e codificado", isso não faz dela o ambiente exclusivo em que "se produz e reproduz o conhecimento"

${ }^{55}$ COMITÊ NACIONAL DE EDUCAÇÃO EM DIREITOS HUMANOS. Plano Nacional de Educação em Direitos Humanos. Brasília: Secretaria Especial dos Direitos Humanos/Ministério da Educação/Ministério da Justiça/UNESCO, 2007, p. 43. Disponível em http://portal.mj.gov.br/sedh/edh/pnedhpor.pdf. Acesso em 23/01/2014.

${ }^{56}$ COMITẾ NACIONAL DE EDUCAÇÃO EM DIREITOS HUMANOS, Plano Nacional de Educação em Direitos Humanos, 2007, p. 31. 
Pois a educação apresenta, também, sua fundamental dimensão não-formal. E esta compreende os processos formativos desenvolvidos em diferentes ambientes, que extrapolam a escola - incluindo organizações sociais, culturais, econômicas e políticas -, e destinados a diversas finalidades (qualificação para o trabalho; a aprendizagem de conteúdos escolares em modalidades diversificadas, como a educação de jovens e adultos e nos presídios; a aprendizagem e prática dos direitos humanos e da democracia) ${ }^{57}$.

Remete, desse modo, nos termos do $3^{-}$Plano Nacional de Direitos Humanos (Decreto Federal n $\mathrm{n}^{\mathrm{o}}$ 7.037/2009), ao "vasto leque brasileiro de movimentos populares, sindicatos, igrejas, ONGs, clubes, entidades empresariais e toda sorte de agrupamentos da sociedade civil que desenvolvem atividades formativas em seu cotidiano".

Os objetivos da educação nacional, nesse seu sentido abrangente, estão previstos na parte final do Art. 205 do texto constitucional. Conferindo relevo a três facetas do ser humano $^{58}$, visa ao pleno desenvolvimento da pessoa, em sua individualidade e identidade; à sua qualificação como trabalhador; e, finalmente, à preparação para o exercício de seu papel de cidadão.

O dispositivo retoma, assim, em grande medida - como, aliás, a Constituição faz em relação aos direitos fundamentais em geral - o previsto nos Tratados e Pactos que compõem o Direito Internacional dos Direitos Humanos. Destaca-se, aqui, o Art. XXVI da Declaração Universal dos Direitos Humanos (adotada pela Resolução n⿳0 217 A - III da Assembleia Geral das Nações Unidas, em 10 de dezembro de 1948) e o Art. 13 do Pacto Internacional sobre os Direitos Econômicos, Sociais e Culturais (adotado pela Assembléia Geral das Nações Unidas, em 16 de dezembro de 1966 e ratificado pelo Brasil em 24/01/1992).

Ambos, após afirmar o direito de toda pessoa à educação, ressaltando sua gratuidade e obrigatoriedade ao menos no nível fundamental, estabelecem, como objetivos da educação, o "pleno desenvolvimento da pessoa humana", prevendo o segundo deles, ainda, a capacitação de todas as pessoas para a participação efetiva numa sociedade livre.

${ }^{57}$ COMITÊ NACIONAL DE EDUCAÇÃO EM DIREITOS HUMANOS, Plano Nacional de Educação em Direitos Humanos, 2007, p. 43.

${ }^{58}$ HORTA, José Luiz Borges. Direito Constitucional da Educação. Belo Horizonte: Decálogo, 2007, p. 127. 
A Constituição não cita, expressamente, outros três objetivos trazidos por esses documentos internacionais: o fortalecimento do "respeito pelos direitos humanos e pelas liberdades fundamentais"; a promoção da compreensão, da tolerância e da amizade entre todas as nações e entre todos os grupos raciais, étnicos ou religiosos; e a promoção das “atividades das Nações Unidas em prol da manutenção da paz”.

Trata-se, contudo, de fins que não podem ser olvidados quando se analisa a educação, a partir de uma leitura sistemática da Constituição, considerando, portanto: a unidade de sentido conferida pela dignidade da pessoa humana, fundamento da República; o extenso rol de direitos fundamentais que projetam a dignidade; os objetivos fundamentais do Estado brasileiro de construção de uma sociedade livre, justa, solidária que consiga erradicar a pobreza e a marginalização, promovendo o bem de todos, sem discriminações (Art. $3^{\underline{o}}$ ); e, por fim, os princípios, a regê-lo na esfera internacional, da defesa permanente da paz, com a prevalência dos direitos humanos (Art. $4^{\underline{0}}$ ).

Essa conexão entre educação e direitos humanos, em conformidade com o Direito Internacional, é recuperada, ademais, de modo vigoroso, no Plano Nacional de Educação em Direitos Humanos (PNEDH), lançado, em 2003, pelo Comitê Nacional de Educação em Direitos Humanos e, com um sentido normativo mais forte, no $3^{\circ}$ Plano Nacional de Direitos Humanos - PNDH 3, aprovado pelo Decreto Federal nº 7.037/2010.

Em seu Eixo Orientador $V$, a educação em direitos humanos é definida como processo multidimensional orientado à formação dos sujeitos de direitos, com uma nova mentalidade e consciência cidadã, nos níveis cognitivo, social, ético e político, para o exercício da solidariedade e do respeito às diversidades. Tem, assim, por escopo "combater o preconceito, a discriminação e a violência, promovendo a adoção de novos valores de liberdade, justiça e igualdade" e se constituindo como "canal estratégico capaz de produzir uma sociedade igualitária", que atualize, em todos os seus espaços e momentos, os valores, atitudes e práticas que expressem a cultura dos direitos humanos.

Configuram-se, dessa forma, os fins da educação no ordenamento jurídicoconstitucional brasileiro. Iluminada pelos ideais e valores do projeto moderno emancipatório, a educação é concebida como o processo de pleno desenvolvimento das potencialidades da pessoa e, ao mesmo tempo, à participação efetiva em todas as esferas da vida social, como cidadão e trabalhador. 
Remete, assim, à capacidade do sujeito histórico, valor-fonte da experiência jurídica $^{59}$, de conceber, projetar e conduzir a própria existência ${ }^{60}$. E isso, na interação social que, de acordo com a caracterização, os fundamentos e os objetivos do Estado brasileiro, deve ocorrer numa ambiência democrática - a se espraiar sobre os diversos momentos da vida social -, e pautar-se no respeito e na afirmação dos direitos humanos.

Nesse contexto, falar em preparo para a cidadania adquire significação toda especial. Sobrepujando, e muito, o indispensável esclarecimento sobre os procedimentos político-eleitorais, "o sistema eleitoral, o direito de votar e de ser eleito, os cargos eletivos a serem disputados e sobre os candidatos a ocupá-los", abrange, também e fundamentalmente, a formação para uma convivência pautada no diálogo que inclui o outro, despertando a "consciência sobre o valor da pessoa humana, suas características essenciais, sua necessidade de convivência e a obrigação de respeitar a dignidade de todos os seres humanos, independentemente de sua condição social e de seus atributos pessoais" $"$.

Destarte, a educação, que constitui o indivíduo na socialização, há de se atualizar na e para a democracia - o que se amalgama, em última análise, à noção de educação em e para os direitos humanos. Nela, os sujeitos, formados numa cultura democrática, imbuída dos valores da liberdade, igualdade, participação, respeito, solidariedade, podem presentificá-la, esparramando seus atributos e qualidades, em todos os campos de sua atuação social.

A educação orientada por esses objetivos efetiva-se em benefício da pessoa humana. E, por essa via, beneficia, também, como já destacava Marshall, a sociedade como um todo ${ }^{62}$.

Distingue-se, assim, a pretensão, socialmente reconhecida, do indivíduo, de ser educado. Sob tal perspectiva, configura-se o direito fundamental que, em relação à

\footnotetext{
${ }^{59}$ LAFER, A reconstrução dos direitos humanos, 1988, p. 15.

${ }^{60}$ KANT, Resposta à pergunta: que é o iluminismo?, 2004, p. 11; DEMO, Cidadania menor, 1992, p. 16; SARLET, Dignidade da pessoa humana e direitos fundamentais na Constituição Federal de 1988, 2011, p.102.

${ }^{61}$ DALLARI, Educação e preparação para a cidadania, 2009, p. 345.

${ }^{62}$ MARSHALL, T. H. Cidadania, classe social e status. Trad. Meton Porto Gadelha. Rio de Janeiro: Zahar, 1967, p. 73.
} 
educação básica, dos quatro aos dezessete anos de idade, constitui um direito público subjetivo, oponível contra o Estado (Art. 208, inciso I e $\S 1^{\underline{0}}$, da Constituição Federal).

E se distingue, também, a pretensão da sociedade, tendo em vista o seu próprio desenvolvimento, de que seus cidadãos - pelo menos numa certa medida - sejam educados. A formação do indivíduo, apto à participação na vida cultural, econômica e política, ao mesmo tempo em que atualiza suas próprias potencialidades, habilitando-o ao exercício de outros direitos, promove o desenvolvimento do Estado e a consecução de seus objetivos fundamentais.

Nessa linha, porque incumbida da preparação dos sujeitos históricos para o exercício da cidadania, a educação volta-se à promoção, o fortalecimento e à consolidação do Estado Democrático de Direito ${ }^{63}$.

Assim, prevista como um direito, a educação aparece, concomitantemente, como um "dever público de exercer o direito" "64. A educação básica é obrigatória. Trata-se de um direito e dever, pois, que se coloca não só dentro da perspectiva iluminista emancipatória e, nela, do reconhecimento da indispensabilidade da formação racional do sujeito para a afirmação de sua dignidade e para a participação na vida social, mas também frente à constatação pragmática de que "o bom funcionamento de uma sociedade depende da educação de seus membros"

Essa ambivalência essencial da educação, referida aos seus fins e destinatários, revela sua magnitude social. Torna inegável seu caráter eminentemente público. E pública em razão de seus fins, não importando quem a esteja prestando, o Poder Público ou o setor privado $^{66}$. No sentido apresentado por Dewey, uma questão pública porque suas consequências projetam-se de modo tão significativo sobre o grupo social que demandam, sob a perspectiva do próprio grupo, tê-lo sistematicamente sob cuidado e controle ${ }^{67}$.

\footnotetext{
${ }^{63}$ RANIERI, Nina Beatriz Stocco. O estado democrático de direito e o sentido da exigência de preparo para o exercício da cidadania, pela via da educação. Tese apresentada para inscrição em concurso visando a obtenção do título de Livre-docente, junto ao Departamento de Direito de Estado da Faculdade de Direito da Universidade de São Paulo. São Paulo, 2009, p. p. 380.

${ }^{64}$ MARSHALL, Cidadania, classe social e status, 1967, p. 74.

${ }^{65}$ MARSHALL, Cidadania, classe social e status, 1967, p. 74.

${ }^{66}$ GRAU, Eros. Constituição e Reforma Universitária. Jornal Folha de São Paulo. São Paulo, 23/01/2005. RANIERI, Nina Beatriz Stocco. Educação superior, direito e estado: na lei de diretrizes e bases (lei $\mathrm{n}^{\mathrm{o}}$ 9.394/96). São Paulo: Edusp/FAPESP, 2000, p. 42 e 78.

${ }^{67}$ DEWEY, The public and its problems, 1991, p. 15 e 16.
} 
A adjetivação da educação como uma matéria pública fica reconhecida na própria Constituição Federal, expressando-se no grande desvelo que lhe confere. Diante disso, pode se afirmar, mesmo, esse seu caráter por determinação constitucional ${ }^{68}$.

Nesse cenário jurídico-constitucional, vale a referência, finalmente, aos atores sociais que repartem a tarefa de educar, indicados na parte inicial do Art. 205: a família, o Estado e a sociedade.

Sem prejuízo do traço público que o tema assume constitucionalmente, é reconhecida a esfera privada da família como o primeiro momento de desenvolvimento e socialização da criança. Nela, tem "sua iniciação como integrante da sociedade humana",69, de acordo com os valores, crenças e conceitos próprios do núcleo familiar. Faz-se como a ambiência necessária de experiência e de aprendizagem naquele círculo das relações afetivas primárias que, com Axel Honneth, definem a esfera de reconhecimento do amor $^{70}$.

Ao lado do ambiente formativo familiar, coloca-se, de forma organizada e sistematizada, a educação formal. Obrigatória no seu nível básico, deve ser assegurada à criança, na instituição social própria, a escola ${ }^{71}$. Representa o momento em que o educando extrapola a esfera privada da família e se encontra, interage com o outro, ainda não abrangido em seu nós.

A educação escolar, somada a outros ambientes educativos não formais, funciona, assim, como espaço fundamental de preparação e entrada na esfera pública. Induz sua identificação, vinculada ao escopo de preparo para a cidadania, como lugar de efetivação do direito da criança ao espaço público ${ }^{72}$.

Nesse espaço, distinguem-se, como instâncias que, com amparo constitucional, responsabilizam-se pela tarefa educativa - seja na rede regular de ensino, seja mediante práticas não formais -, o Estado e a sociedade civil.

${ }^{68}$ MELlo, Celso Antônio Bandeira de. Curso de Direito Administrativo. 27 $7^{\mathrm{a}}$ ed. rev. e atual. São Paulo: Malheiros, 2010, p. 687.

${ }^{69}$ DALLARI, Educação e preparação para a cidadania, 2009, p. 325.

${ }^{70}$ HONNETH, Luta por Reconhecimento, 2009, p. 159.

${ }^{71}$ DALLARI, Educação e preparação para a cidadania, 2009, p. 325 . De acordo com o Art. 6을 da Lei de Diretrizes e Bases da Educação Nacional (nº 9.394/1996), "É dever dos pais ou responsáveis efetuar a matrícula das crianças na educação básica a partir dos 4 (quatro) anos de idade".

72 ALMEIDA, Guilherme de Assis. Aula ministrada na disciplina Direitos humanos fundamentais do Programa de Pós-Graduação Stricto Sensu em Direito da Universidade de São Paulo. São Paulo, 29/04/2013. 
Em relação ao Estado, importa destacar que a educação aparece como um dever que abrange um catálogo maior de competências legais. São elas:

Primeiro, a organização e regulamentação dos sistemas de ensino. Observando o disposto na Lei de Diretrizes e Bases e nas demais normas gerais da educação nacional, instituídas pela União (Artigos 22, inciso XXIV, e 24, inciso IX e $§ 1^{\circ}$, da Constituição Federal), cada um dos entes da federação organiza, em regime de cooperação, seu próprio sistema de ensino (Art. 211 da Constituição Federal).

Nesse cenário, cabe à União a coordenação da política nacional de educação, articulando os diferentes níveis e sistemas e exercendo a função normativa, redistributiva e supletiva, visando a assegurar a "equalização de oportunidades educacionais e padrão mínimo de qualidade do ensino”. Mas não é só. Cumpre-lhe, também, a organização do sistema federal de ensino, o qual compreende os órgãos federais de educação; as instituições de ensino mantidas pela União; e as instituições de educação superior mantidas pela iniciativa privada (Art. 211 da Constituição Federal; Artigos $8^{\circ}$ e 16 da Lei de Diretrizes e Bases).

Os Estados e o Distrito Federal organizam o respectivo sistema estadual/distrital de ensino, que, atuando prioritariamente no ensino fundamental e médio (Art. 211, $\$ 3^{\circ}$, da Constituição Federal), compreende: as instituições de ensino por eles mantidas; as instituições de educação superior mantidas pelo Poder Público municipal; as instituições de ensino fundamental e médio mantidas pela iniciativa privada; e seus órgãos estaduais/distritais de educação (Art. 17 da Lei de Diretrizes e Bases).

Cada município organiza seu sistema municipal de ensino. Dedicado prioritariamente à educação fundamental e infantil (Art. 211, §2º , da Constituição Federal), abrange: as instituições do ensino fundamental, médio e de educação infantil mantidas pelo Poder Público municipal; as instituições de educação infantil mantidas pela iniciativa privada; e os órgãos municipais de educação (Art. 18 da Lei de Diretrizes e Bases).

É essa organização jurídico-constitucional que estrutura e viabiliza, então, outras atuações estatais no campo educacional.

Nesse sentido, menciona-se, em segundo lugar, a função de regulação, avaliação $e$ fiscalização da prestação da educação pelas instituições e estabelecimentos escolares, públicos e privados. 
Em terceiro lugar, o dever de manter escolas, prestando, diretamente, o ensino. Trata-se, assim, do "ensino público", no sentido de que seu prestador é o Poder Público e não a iniciativa privada. Nos termos do Art. 206, incisos IV e VI, da Constituição Federal, deve ser prestado gratuitamente e gerido de forma democrática. Ademais, conforme já mencionado, em relação à educação básica, cumpre ao Estado oferecê-la de forma obrigatória às crianças e adolescentes dos quatro aos dezessete anos (Art. 208, inciso I, da Constituição Federal).

Finalmente, importa lembrar a atuação do Poder Público, também, na promoção de práticas educacionais não formais. O $3^{0}$ Plano Nacional de Direitos Humanos reconhece tal modalidade de educação como "espaço de defesa e promoção dos direitos humanos" (Diretriz $\mathrm{n}^{-}$20) e relaciona importantes ações programáticas do Estado nesse campo - o fomento à inclusão da temática de direitos humanos em projetos e programas de qualificação profissional, de alfabetização de jovens e adultos, de extensão rural, de educação comunitária, de esporte, cultura e lazer, e de inclusão digital; o apoio a iniciativas de educação popular em direitos humanos desenvolvidas por organizações comunitárias e movimentos sociais, dentre outras.

Passando, agora, à participação social no desenvolvimento da educação, formal e informal, na sociedade democrática, destacam-se dois sentidos de atuação.

Primeiro como prestador educacional. Independentemente do resultado do debate acerca da preferência constitucional, ou não, pelo ensino prestado pelo Poder Público - e, assim, sobre o papel prioritário ou secundário concedido ao setor privado ${ }^{73}$ - a presença de iniciativas educacionais de associações e organizações da sociedade civil não pode, absolutamente, ser negada.

A liberdade de ensinar da iniciativa privada está expressamente resguardada pelo Art. 209 da Constituição Federal, decorrendo, ainda, de princípios constitucionais, em matéria de educação, previstos no Art. 206, incisos II e III: a "liberdade de aprender, ensinar, pesquisar e divulgar o pensamento, a arte e o saber", a "pluralidade de ideias e concepções pedagógicas" e a "coexistência de estabelecimentos públicos e privados de ensino".

\footnotetext{
${ }^{73}$ HORTA, Direito constitucional da educação, 2007, p. 126.
} 
Por outro lado, tal liberdade não é, evidentemente, irrestrita. Recebe, ainda no texto constitucional, significativas e incontestáveis restrições, decorrências necessárias do sentido assumido pela educação na ordem constitucional. Trata-se, afinal, de uma atividade pública em razão de seus fins e de sua magnitude social, referida a um direito fundamental que radica na dignidade da pessoa humana, fundamento do Estado Democrático de Direito brasileiro.

A prática da educação, no Brasil, não pode perder, jamais, tais referências.

Nesse sentido, em conformidade com os mesmos dispositivos há pouco aludidos (Artigos 206 e 209, da Constituição Federal), o prestador educacional privado - como também o Poder Público - deve cumprir, com rigor, as normas gerais da educação nacional, assegurar o padrão de qualidade e submeter-se aos processos avaliativos e regulatórios aplicados pelos órgãos públicos responsáveis.

Mas não é só. A tarefa educacional, por quem quer que seja realizada, deve orientar-se aos objetivos constitucionalmente estabelecidos. E se não pode perverter-se em instrumento de pretensões internas ao poder político, também não pode, na esfera privada, ser corrompida em empreendimento econômico, com intuito lucrativo.

Sob tal perspectiva, delineia-se, ademais, o outro sentido da participação da sociedade civil. Cumpre-lhe atuar, de modo decisivo, orientando e colaborando com o Estado na formulação, na organização e na implantação da legislação e das políticas públicas educacionais. Tem, dessa forma, papel fundamental na construção democrática de um sistema pedagogicamente estruturado: nem a educação estatizada, assimilada ao sistema político e sua lógica interna de poder; nem, no outro extremo, a educação monetarizada, absorvida e instrumentalizada pela atividade empresarial lucrativa ${ }^{74}$.

1.5. Constitui-se, nesse cenário jurídico, o Estado brasileiro. Fundamentado e orientado pelo valor intrínseco, único e insubstituível da pessoa humana ${ }^{75}$ e organizado sob a forma da democracia, reconhece juridicamente extensas "propriedades que caracterizam o ser humano constitutivamente como pessoa" ${ }^{, 76}$. E isso, no sentido de um sujeito histórico capaz

\footnotetext{
${ }^{74}$ HABERMAS, Jürgen. Teoria do agir comunicativo. Sobre a crítica da razão funcionalista. Tomo 02. Trad. Flávio Beno Siebeneichler. São Paulo: Editora WMF Martins Fontes, 2012, p. 587, 588 e 667.

${ }^{75}$ COMPARATO, A afirmação histórica dos direitos humanos, 2013, p. 43.

${ }^{76}$ HONNETH, Luta por reconhecimento, 2009, p. 188.
} 
de agir com autonomia e, consequentemente, de participação na vida social e, nela, na formação racional da vontade.

Acolhe, pois, a concepção, bastante enriquecida, contemporânea e democrática de cidadania $^{77}$. Congregando as cinco categorias de direitos fundamentais a que Habermas faz referência, conjuga ao reconhecimento da universalidade, a interdependência $\mathrm{e}$ indivisibilidade desses direitos, o processo de especificação do sujeito de direito, em sua identidade irrepetível" ${ }^{78}$, com o que ele "deixa de ser visto em sua abstração e generalidade e passa a ser concebido em sua concretude, em suas especificidades e peculiaridades"79.

Visto por esse ângulo, ainda que haja extenso espaço para reformas e o refinamento dos direitos, o ordenamento jurídico-constitucional assegura, no plano do dever ser, condições para a realização do inacabado projeto emancipatório de modernidade. E permite, em virtude disso, concomitantemente, uma legitimidade a partir da própria legalidade democrática.

Afinal, resguarda aos cidadãos o status de sujeitos de direito e, ao mesmo tempo, os instrumentos para que, superando o papel de "meros espectadores da jornada jurídicopolítica" ${ }^{\circ 0}$, atuem como autores do próprio direito.

\section{A experiência histórico-constitucional da democracia no Brasil}

Tal configuração do Estado Democrático de Direito, fortemente alicerçado nos direitos humanos, é promulgada e, pode-se dizer, arremessada no curso de um processo histórico em que a população não o havia internalizado, nem poderia, como experiência própria.

Sucedendo ao período ditatorial militar, erige-se sobre uma experiência que, contrastando visceralmente com valores iluministas afirmados pela modernidade, no bojo da qual fora gerada, tratou seres humanos, por mera divergência político-ideológica, como

${ }^{77}$ COMITÊ NACIONAL DE EDUCAÇÃO EM DIREITOS HUMANOS. Plano Nacional de Educação em Direitos Humanos, 2007, p. 23; PIOVESAN, Temas de direitos humanos, 2003, p. 340. PIOVESAN, Direitos humanos e o direito constitucional internacional, 2012, p. 69.

${ }^{78}$ SARLET, Dignidade da pessoa humana e direitos fundamentais na Constituição Federal de 1988, 2011, p. 105.

${ }_{79}$ PIOVESAN, Temas de direitos humanos, 2003, p. 338.

${ }^{80}$ MOREIRA, Luiz. Fundamentação do direito em Habermas. $3^{\mathrm{a}}$ ed. rev. atual. e amp. Belo Horizonte: Mandamentos, 2004, p. 126. 
supérfluos e descartáveis e fez do direito positivo instrumento de gestão autoritária da sociedade $^{81}$.

A Constituição de 1988 acompanha, em alguma medida, a linha de nosso jurismo, descrito por Nestor Duarte: antecipa a vida social por meio de reformas legislativas ${ }^{82}$, esforçando-se "por construir com a lei, antes dos fatos, uma ordem política e uma vida pública que os costumes, a tradição e os antecedentes históricos não formaram, nem tiveram tempo de sedimentar e cristalizar" ${ }^{83}$. Um trabalho, muitas vezes, sobre o terreno vazio ${ }^{84}$, edificando-se "nas nuvens, sem contar com a reação dos fatos, para que da lei ou plano saia o homem tal como no laboratório de Fausto" ${ }^{\text {" }}$.

Contudo, olhando para o passado e diante dos caminhos que se abriam, naquele momento, não se pode questionar, nem olvidar, a significação fundamental do texto constitucional, como marco para a construção e consolidação da democracia no Brasil.

Um breve recuo à história das Constituições brasileiras, em grande medida outorgadas, outras vezes mera legalidade teórica, contraposta à continuidade experiencial predominantemente autoritária, dá um sinal bastante claro dessa situação.

2.1. A primeira Constituição brasileira foi outorgada, em 1824, por Dom Pedro I, filho do monarca português. Segue à "independência" do país, datada de 1821, movimento que representou não a descolonização, mas, apenas, "o translado da regência política, encarnada por um rei português, sediado em Lisboa, para seu filho, assentado agora no Rio de Janeiro, de onde negociara a independência nacional com a potência hegemônica da época, que era a Inglaterra" ${ }^{\circ 6}$.

O texto, assim, constituiu, no campo econômico, amparado por uma classe dominante que se "nacionaliza alegremente, preparando-se para lucrar com o regime autônomo, tal como lucrara com o colonial”. E o fez sobre o que havia sido até então, e

\footnotetext{
${ }^{81}$ LAFER, A reconstrução dos direitos humanos, 1988, p. 15, 19 e 78.

${ }^{82}$ FAORO, Raymundo. Os donos do poder. Formação do patronato político brasileiro. Volume 02. $11^{\mathrm{a}} \mathrm{Ed}$. São Paulo: Globo, 1995, p. 745.

83 DUARTE, Nestor. A ordem privada e a organização política nacional, São Paulo/Rio de Janeiro/Recife/Porto Alegre: Companhia Editora Nacional, 1939, p. 221.

${ }^{84}$ DUARTE, A ordem privada e a organização política nacional, p. 222.

${ }^{85}$ FAORO, Os donos do poder, 1995, p. 744 e 745.

${ }^{86}$ RIBEIRO, O povo brasileiro, 2006, p. 230.
} 
continuaria sendo, uma empreitada comercial, baseada na grande propriedade, na exportação de produtos agrícolas e no trabalho escravo ${ }^{87}$.

No campo político, instituiu um governo monárquico, cuja organização trazia, ao lado dos três poderes referidos pela teoria liberal da separação dos poderes $^{88}$ - o Legislativo, o Judiciário e o Executivo -, e juntamente com este último, um quarto, o Moderador, nas mãos do Imperador. Nos termos da Constituição Imperial, tratava-se de um poder "neutro" por meio do qual o Chefe Supremo da Nação velaria, "sobre a manutenção da independência, equilíbrio e harmonia dos mais Poderes Políticos". Correspondia, assim, a um expediente com o qual o Imperador se colocava "acima" das "questões partidárias" e das "mesquinharias dos interesses de grupos" e zelaria, sem responsabilidade, pela Nação e pelo Estado ${ }^{89}$.

Manteve-se, assim, o cenário colonial marcado pela verticalidade das relações, do antidiálogo, do poder exacerbado dos "donos das terras e das gentes", sem a participação da população na constituição e organização da vida social ${ }^{90}$.

2.2. A Constituição imperial vigeria até 1889 , quando cai a monarquia. Na linha do que constituiria uma tradição política, contraditória, na qual república e democracia podem ser antecipadas e impostas, sem a participação do público, Aristides Lobos - ministro do interior do gabinete revolucionário de Deodoro da Fonseca - afirmou: "Eu quisera dar a esta data a seguinte denominação: 15 de novembro do primeiro ano da República; mas não posso infelizmente fazê-lo. O que se fez é um degrau, talvez nem tanto, para o advento da grande era" ${ }^{91}$. E concluiu com o trecho tão repetido desde então:

Por ora, a cor do governo é puramente militar e deverá ser assim. O fato foi deles, deles só. Porque a colaboração do elemento civil foi quase nula. O povo assistiu àquilo bestializado, atônito, surpreso, sem conhecer o que significava. Muitos acreditavam sinceramente estar vendo uma parada ${ }^{92}$.

\footnotetext{
${ }^{87}$ RIBEIRO, O povo brasileiro, 2006, p. 230.

${ }^{88}$ DALLARI, Elementos de teoria geral do estado, 2010, p. 216 e 219.

${ }^{89}$ LIMA LOPES, José Reinaldo. $O$ direito na história. Lições introdutórias. $2^{\text {a }}$ ed. revista. São Paulo: Max Limonad, 2002, p. 317.

${ }^{90}$ FREIRE, Educação como prática de liberdade, 2011, p. 93, 94, 99 e 100.

${ }^{91}$ MARTINS, Luís. O patriarca e o bacharel. 2ª ed. São Paulo: Alameda, 2008, p. 119.

92 MARTINS, O patriarca e o bacharel, 2008, p. 119.
} 
Iniciava a primeira experiência republicana brasileira, inaugurando-se, então, a tentativa de um estado democrático sobre uma vasta e profunda inexperiência de autogoverno e vivência comunitária.

A República Velha perduraria até 1930, sob a égide da Constituição de 1891. No seu texto, uma Constituição promulgada "para organizar um regime livre e democrático". $\mathrm{Na}$ prática, o coronelismo e os expedientes a ele relacionados do paternalismo, do patrimonialismo, do mandonismo e do falseamento de voto ${ }^{93}$.

O sistema coronelista, conforme a lição de Victor Nunes Leal, é o "resultado da superposição de formas desenvolvidas do regime representativo a uma estrutura econômica e social inadequada". Compôs-se como um compromisso entre o poder privado dos senhores da terra locais (os coronéis) e o Poder Público ${ }^{94}$, num sistema de reciprocidade:

(...) de um lado, os chefes municipais e os "coronéis", que conduzem magotes de eleitores como quem toca tropa de burros; de outro lado, a situação política dominante no Estado, que dispõe de erário, dos empregos, dos favores e da força policial, que possui, em suma, o cofre das graças e o poder da desgraça ${ }^{95}$.

Com efeito, o coronelismo se realiza na continuidade da organização colonial agrária, que fornecia “a base de sustentação das manifestações de poder privado tão visíveis no interior do Brasil", num novo quadro de abolição formal da escravidão. Durante a República Velha, permaneceu, grosso modo, a estrutura formada pela grande propriedade e pela sujeição da gigantesca massa trabalhadora rural à pequena minoria de fazendeiros, “poderosa em relação aos seus dependentes, embora de posição cada vez mais precária no conjunto da economia nacional" 96 .

Nesse contexto, parasitariamente, pode se aproveitar da extensão democrática do direito de sufrágio a um grande contingente de eleitores incapacitados para o consciente exercício do voto. No retrato de Victor Nunes Leal, homens e mulheres analfabetos, desinformados, "não lendo jornais, nem revistas, nas quais se limita a ver figuras", alheios aos processos políticos, vivendo no "mais lamentável estado de pobreza, ignorância e abandono". Contavam, apenas, com o "auxílio" do coronel, o benfeitor responsável pelos

\footnotetext{
${ }^{93}$ LEAL, Victor Nunes. Coronelismo, enxada e voto. O município e o regime representativo no Brasil. São Paulo: Alfa-omega, 1978, p. 20.

${ }^{94}$ LEAL, Coronelismo, enxada e voto, 1978, p. 20.

${ }^{95}$ LEAL, Coronelismo, enxada e voto, 1978, p. 43.

${ }^{96}$ LEAL, Coronelismo, enxada e voto, 1978, p. 20 e 253. O autor complementa que embora houvesse, entre os coronéis, considerável parcela de fazendeiros abastados, muitos deles só eram ricos em comparação com a "pobreza sem remédio" do roceiro.
} 
"melhoramentos locais" (a estrada, o posto de saúde, etc.), ao qual se recorre nos "momentos de apertura" e de quem provém os únicos favores que a "obscura existência conhece". Tudo a formar um cenário miserável em que se revela perfeitamente compreensível a obediência do trabalhador rural às suas ordens, integrando-se, sem resistência, em seu "rebanho eleitoral"

Em sua situação, seria ilusório pretender que esse novo pária tivesse consciência do seu direito a uma vida melhor e lutasse por ele com independência cívica. O lógico é o que presenciamos: no plano político, ele luta com o "coronel" e pelo "coronel”. Aí estão os votos de cabresto, que resultam, em grande parte, da nossa organização econômica rural ${ }^{98}$.

No fundo, a primeira experiência democrática brasileira correspondeu a um sistema assentado, basicamente, em fraquezas. A fraqueza do coronel, que "se ilude com o prestígio do poder, obtido à custa da submissão política” e, assim, uma fraqueza que só aparenta "fortaleza" em contraste com a situação da massa de trabalhadores pobres que "vive sob suas asas e enche as urnas eleitorais a seu mandado"; a fraqueza desamparada do trabalhador rural; e, finalmente, a fraqueza do poder político, que, diante da afirmada superposição do regime representativo a uma estrutura socioeconômica inadequada, foram levados a se compor com os coronéis, condutores do "rebanho eleitoral" 99.

2.3. Em 1930, pela via do golpe de Estado, assume o poder Getúlio Vargas, que nele permanece até 1945. Nesse período, após quatro anos sem Constituição, é promulgado o texto de 1934, com vigência efêmera, até 1937, quando, então, é outorgada nova Constituição. Fortemente influenciada pelo contexto mundial totalitário, marca o início da Ditadura do Estado Novo.

Trata-se de texto cujo preâmbulo é revelador de seu autoritarismo e incompatibilidade com a experiência do diálogo e da participação social. É o "Presidente", o pai do povo ${ }^{100}$, quem, com apoio das forças armadas, resolve decretá-lo. E, como condutor da sociedade, impõe-na visando a atender às "legitimas aspirações do povo brasileiro à paz política e social", "profundamente perturbadas" por fatores de desordem, e não atendidas pela organização institucional precedente.

\footnotetext{
${ }^{97}$ LEAL, Coronelismo, enxada e voto, 1978, p. 24, 25, 36, 37 e 253.

${ }^{98}$ LEAL, Coronelismo, enxada e voto, 1978, p. 25.

${ }^{99}$ LEAL, Coronelismo, enxada e voto, 1978, p. 56 e 253.

${ }^{100}$ FAORO, Os donos do poder, 1995, p. 740.
} 
Segue a concepção autoritária do principal jurista do Estado Novo, Francisco Campos, para quem "o regime político das massas é o da ditadura". A seu ver, somente a liderança carismática, num Estado autoritário, poderia eliminar os conflitos sociais desestabilizadores ${ }^{101}$.

Contudo, como destaca Gilberto Bercovici, "por mais paradoxal que isso possa parecer, a Carta de 1937 nunca foi aplicada”. Dissolveu o Poder Legislativo em todas as esferas governamentais (Art. 178), prevendo, ainda, a convocação de eleições depois da realização de plebiscito para que a população se manifestasse sobre a adoção do texto constitucional (Art. 187). Enquanto não se reunisse o Parlamento, o Presidente teria o poder de expedir decretos-leis para legislar sobre as matérias de competência da União. Nesse contexto, "Como não foi realizado o plebiscito, não foram marcadas as eleições parlamentares previstas na própria Carta de 1937, que não foi cumprida. O que houve durante o Estado Novo foi ditadura pura e simples do Chefe do Poder Executivo"102.

2.4. O regime político democrático é restaurado após a queda de Getúlio Vargas e a promulgação da Constituição de 1946.

Trata-se de período marcado por sucessivas crises políticas e o recurso frequente a expedientes golpistas - a começar com a derrubada do então ditador. Destacam-se, nesse sentido: a reação conservadora e militar ao programa econômico e social de Getúlio Vargas, eleito Presidente da República, em 1951, culminando com seu suicídio, em 1954; em 1955, a deposição do Presidente interino Carlos Luz (Presidente da Câmara dos Deputados que assumira o Executivo Federal com o adoecimento de Café Filho), pelos Militares, que impedem, também, o retorno do Presidente; rebeliões golpistas contra Juscelino Kubitschek; e as tentativas conservadoras e militares de impedir que João Goulart assumisse a Presidência, após a renúncia de Jânio Quadros, em $1961^{103}$.

Por outro lado, tal período marca a transição do país para uma democracia de massas, com o aparecimento e multiplicação de movimentos e organizações sociais no

\footnotetext{
101 BERCOVICI, Gilberto. Tentativa de instituição da democracia de massas no Brasil: instabilidade constitucional e direitos sociais na Era Vargas (1930-1964). In FONSECA, Ricardo Marcelo e SEELAENDER, Airton Cerqueira Leite. História do Brasil em perspectiva. Do Antigo Regime à Modernidade. Curitiba: Juruá, 2009, p. 390.

102 BERCOVICI, Tentativa de instituição da democracia de massas no Brasil, 2009, p. 390.

${ }^{103}$ WEFFORT, Por que democracia?, 1984, p. 41; SILVA, Curso de direito constitucional positivo, 2010, p. 85 e 86.
} 
Brasil - destacando-se, aqui, as Ligas Camponesas e as Comunidades Eclesiais de Base-, num contexto de urbanização e industrialização crescentes ${ }^{104}$.

Tal movimentação encetada pela população assustou as classes médias, a elite econômica, as oligarquias e o setor empresarial, ameaçados nos seus privilégios, com a ascensão popular. Eis a base do golpe militar, ação que se esboçava desde 1945 e que impõe, em 1964, mais uma vez, a ditadura no Brasil ${ }^{105}$. Seu primeiro objetivo, ressalta Dalmo A. Dallari: "impedir a continuidade do processo democratizante"106.

2.5. A atividade política dos militares adquire substância na era republicana ${ }^{107}$. Intervieram no arranjo institucional do país, ao lado dos "revolucionários", ou apenas "golpistas", nos processos de mudança do regime constitucional de 1889, 1930, 1937, 1945. Nesse momento, em 1964, assumem, diretamente, o governo de índole ditatorial.

E o fazem sob o discurso ambíguo e cínico em relação ao regime democrático e aos direitos fundamentais que, autoritariamente, afirmam defender, no âmbito uma legalidade que, a todo custo, buscam preservar.

Convertido o primado da legalidade democrática em bandeira consensual do mundo ocidental - - notadamente na segunda metade do século XX -, a retórica política não pode mais legitimar o exercício do poder (mesmo o despótico) sem mencionar suas raízes no povo ou na cidadania ${ }^{108}$.

Nesse sentido, no plano jurídico, continuando a tradição política viciada pela "enorme distância entre o que as intenções proclamam e o que as ações fazem" "109, nova Constituição é outorgada em 1967, sendo, dois anos mais tarde, inteiramente emendada pela Emenda Constitucional no ${ }^{-01 / 69}$.

104 DALLARI, Educação e preparação para a cidadania, 2009, p. 330 e 331; FREIRE, Educação como prática de liberdade, 2011, p. 103.

${ }^{105}$ DALLARI, Educação e preparação para a cidadania, 2009, p. 330 e 331; BERCOVICI, Tentativa de instituição da democracia de massas no Brasil, 2009, p. 390; FREIRE, Educação como prática de liberdade, 2011, p. 109 e 110.

${ }^{106}$ DALLARI, Educação e preparação para a cidadania, 2009, p. 331.

${ }^{107}$ FAORO, Os donos do poder, 1995, p. 746 e 747.

108 WEFFORT, Por que democracia?, 1984, p. 53; MOISÉS, Os brasileiros e a democracia, 1995, p. 82; VIOLA, Direitos humanos no Brasil: abrindo portas sob neblina, 2007, p. 126; CARVALHO, Cidadania no Brasil, 2010, p. 07.

${ }^{109}$ WEFFORT, Por que democracia?, 1984, p. 53. 
No preâmbulo da Emenda, é notável o véu de legalidade que se pretende atribuir ao texto imposto: os Ministros da Marinha, do Exército e da Aeronáutica "promulgam" a Constituição, fazendo referência a atribuições "legalmente" conferidas por dispositivos de Atos Institucionais ( $\mathrm{n}^{\mathrm{os}} 05$ e 16). O fazem, ademais, considerando, entre outros pontos, o decreto de "recesso" do Congresso Nacional, diante do que, conforme o referido Ato Institucional $\mathrm{n}^{\mathrm{o}}$ 05, o "Poder Executivo fica autorizado a legislar sobre todas as matérias", inclusive elaborar emendas à Constituição, medida "compreendida no processo legislativo".

E, ao longo documento, sustenta-se a emanação do poder do povo e seu exercício em seu nome (Art. $\left.1^{\underline{o}}, \S 1^{\circ}\right)$. Afirma-se o regime democrático e sua proteção, com o cuidado, porém, de adjetivá-lo, primeiro, de representativo (Artigos 1ํㅜ 151 , inciso I; 152 , inciso I; 154; e 174, $\S 2^{\underline{0}}$ ). Relacionam-se também, direitos de nacionalidade, direitos individuais de liberdade e direitos políticos de participação (Artigos 145 a 154).

Contudo, abaixo da formalidade jurídica, instituiu-se o regime autoritário, com a prática cotidiana da repressão, da tortura - por meio de todo tipo de agressão física e psicológica, incluindo expedientes como "pau de arara", choque elétrico, afogamento, violência contra crianças e mulheres e abortamentos -, do sequestro, do assassinato e do “desaparecimento", praticados pelo próprio Estado. Na realidade, constituía uma rotina o “desrespeito aos direitos constitucionais e às próprias leis criadas pelo Regime, quando se tratava de assegurar aos órgãos de repressão um domínio absoluto sobre os investigados"110.

Por vinte anos, o Brasil foi afastado da vivência da democracia, experienciando, frente ao Estado opressor, relações unilaterais de ordem e obediência, de não participação e não diálogo, de violência.

Quanto à redemocratização que se seguiu, no nível jurídico-formal, deu-se em etapas. A campanha das Diretas Já, a partir do final de 1983 e durante o ano de 1984, se marcou, com grandes manifestações de massa, a passagem do discurso de defesa da democracia e dos direitos humanos às mãos da sociedade civil, não foi vitoriosa quanto ao objetivo ao restabelecimento das eleições diretas para a Presidência da República ${ }^{111}$.

\footnotetext{
${ }^{110}$ ARQUIDIOCESE DE SÃO PAULO. Brasil: nunca mais. 20ํㅡㄹ ed. Petrópolis: Vozes, 1987, p. 88.

${ }^{111}$ WEFFORT, Por que democracia?, 1984, p. 58; VIOLA, Direitos humanos no Brasil: abrindo portas sob neblina, 2007, p. 127 e 128.
} 
Somente em 1988, com a promulgação da Constituição, tem início o atual período democrático brasileiro. E, dois anos mais tarde, sob sua guarida, o Brasil pode eleger, pelo voto direto, o Presidente da República, o primeiro em quase trinta anos.

2.6. Esse passeio panorâmico sobre o passado constitucional brasileiro, embora bastante breve, permite que se vislumbre a medida da história democrática do país, até a promulgação do texto de 1988. Foram, ao todo, aproximadamente sessenta anos de democracia formal, vilipendiada e atacada na prática e entrecortada por golpes de Estado e regimes autoritários.

Eis um legado de inexperiência da democracia, marcado, mais, pela unilateralidade e opressão na relação do Estado com a sociedade ${ }^{112}$, pela conivência com expediente golpista para o exercício do poder, em detrimento do diálogo, e pelo hábito contraditório e cínico em relação à democracia. Tudo isso ao ponto de consentir com a autoproclamação, pelo "Presidente" militar imposto, o general João Baptista Figueiredo, como o caminho autoritário da democratização: "eu hei de fazer este país uma democracia"113.

Deixando raízes profundas no presente, a inexperiência democrática - confundida com a inexperiência da cultura dos direitos humanos - sobrecarrega-o sobremaneira e descortina a questão do desafio da consolidação da democracia, arquitetada pelo ordenamento constitucional.

\section{Democracia, direitos humanos e educação no presente brasileiro}

A promulgação do Estado Democrático de Direito, fundado na pessoa humana e alicerçado nos direitos humanos, fez com que, tecnicamente, passasse a integrar o ordenamento jurídico-constitucional. Contudo, apesar de sua importância fundamental, não significou, evidentemente, a experiência de sua internalização em hábitos e atitudes: a cultura da democracia e dos direitos humanos, como experiência histórica, não surge de pronto, como "geração espontânea" de uma intenção normatizada.

\footnotetext{
${ }^{112}$ RICUPERO, Bernardo. Sete lições sobre as interpretações do Brasil. $2^{\underline{a}}$ ed. São Paulo: Alameda, 2008, p. 168.

${ }^{113}$ WEFFORT, Por que democracia?, 1984, p. 32 e 40.
} 
O grande entusiasmo, em certa medida ingênuo, em relação à redemocratização e às perspectivas de iminente prosperidade e felicidade nacional a partir dela ${ }^{114}$, não afastou, em definitivo, nas continuidades que marcaram a história do Brasil, os hábitos e práticas conformados às experiências antirrepublicanas e antidemocráticas do não diálogo, do patrimonialismo, do paternalismo e do desrespeito aos direitos humanos, incorporados, enraizados e naturalizados no pano de fundo das relações sociais ${ }^{115}$.

Quanto à tradição assim (de)formada, convivendo com a nova ordem jurídica, tem grande potencial limitador e corrosivo das transformações previstas no projeto constitucional $^{116}$.

3.1. No cenário político, vislumbra-se, de um lado, uma elite que se apropriou do Poder Público e que persiste sobranceiramente autônoma e dissociada da sociedade civil: "Atua em nome próprio, servida de instrumentos políticos derivados de sua posse do aparelhamento estatal". Marcadamente fluída e amorfa, conseguiu preservar o poder e seus privilégios, resistindo e compatibilizando-se, na medida do possível, em mudanças de acomodação (jamais estruturais), com o avanço da modernidade e do capitalismo. Deste, aliás, aceitou "a técnica, as máquinas, as empresas, sem aceitar-lhe a alma ansiosa de transmigrar". Daí seu conservadorismo pré-moderno, adaptando-se, na modernidade, às circunstâncias para a manutenção do status patrimonialista de donos do poder $^{117}$.

A isso se agregam, amalgamam-se e se confundem, ainda, tantos outros vícios do mesmo feitio.

Um deles é a "ética governista", na qual, ante o objetivo imediato de permanecer ao lado do e no poder, "os compromissos não são assumidos à base de princípios políticos, mas em torno de coisas concretas, (que) prevalecem para uma ou para poucas eleições próximas" $" 118$. Marca fundamental do sistema coronelista da Velha República, aludida "ética" mostra-se, ainda, vigente, subjacente a lugares-comuns da política nacional, como as contraditórias alianças partidárias que se formam a cada Eleição; as incompatibilidades

\footnotetext{
${ }^{114}$ CARVALHO, Cidadania no Brasil, 2010, p. 07.

115 BENEVIDES, Em defesa da república e da democracia, 2009, p. 727.

${ }_{116}^{116}$ MOISÉS, Os brasileiros e a democracia, 1995, p. 27. BENEVIDES, A cidadania ativa, 2003, p. 194.

${ }^{117}$ FAORO, Os donos do poder, 1995, p. 736, 737, 739 e 745.

${ }^{118}$ LEAL, Coronelismo, enxada e voto, 1978, p. 41.
} 
entre as alianças estabelecidas nas esferas local, regional e federal; as constantes recomposições de coligações partidárias; e as infindáveis trocas de partido pelos políticos.

Ao seu lado, verifica-se a sobrevivência do paternalismo, casado com o populismo, em que, sob o simulacro da proteção do cidadão menor, desvalido ${ }^{119}$, dissimula-se a inaptidão à experiência horizontalizada e dialógica da democracia:

... o líder será sempre alguém que já se encontra no controle de alguma função pública - um presidente, governador, deputado -, isto é, alguém que, por sua posição no sistema institucional de poder, tem a possibilidade de "doar", seja uma lei favorável às massas, seja um aumento de salário ou, mesmo, uma esperança de dias melhores ${ }^{120}$.

Caminham, desse modo, de mãos dadas com o filhotismo, o clientelismo e o mandonismo, nas formas do nepotismo e outros expedientes de favoritismo aos aliados e de perseguições de adversários. Manifestou-se, na Velha República, de um lado, em favores de toda ordem aos aliados: desde o emprego público até os mínimos obséquios, passando por redigir cartas, emprestar dinheiro, contratar advogado, providenciar médico e hospitalização, "influenciar” jurados, "preparar” testemunhas e compor desavenças. Enfim, "Para favorecer os amigos, o chefe local resvala muitas vezes para a zona confusa que medeia entre o legal e o ilícito, ou penetra em cheio no domínio da delinquência, mas a solidariedade partidária passa sobre todos os pecados uma esponja regeneradora". De outro lado, a utilização contra os "inimigos políticos" dos instrumentos à disposição, se possível, a $l e i^{121}$.

Na colagem patrimonialista ao poder, o direito, sem a força da institucionalização, confunde-se com o privilégio, valendo como "reflexo direto e imediato dos interesses ou da força daqueles que se empenham em sua aplicação"122.

Finalmente, importa destacar, a continuidade da mentalidade tipicamente autoritária e verticalizada, no exercício do poder. É notável, ainda, na atuação da elite política, o espanto inconformado diante da "insubordinação" do oprimido, sentimento de "surpresa" que remonta ao período colonial: "a grande perplexidade das classes dominantes atuais é que esses descendentes daqueles negros, índios e mestiços ousem

\footnotetext{
${ }^{119}$ DEMO, Cidadania menor, 1992, p. 108.

${ }^{120}$ WEFFORT, Francisco C. O populismo na política brasileira. 5ª ed. São Paulo: Paz e terra, 2003, p. 82.

${ }^{121}$ LEAL, Coronelismo, enxada e voto, 1978, p. 38 e 39.

${ }^{122}$ WEFFORT, Por que democracia?, 1984, p. 42.
} 
pensar que este país é uma república que deve ser dirigida pela vontade deles como seu povo que são" ${ }^{, 123}$.

Exemplificam esse sentimento, muitas vezes furioso, contra a "insubordinação", as reações "violentas e desinformadas", amplificadas pelos meios de comunicação, em relação ao $3^{\text {o }}$ Plano Nacional de Direitos Humanos, aprovado pelo Decreto Federal $\mathrm{n}^{\mathrm{o}}$ 7.037/2010. São indicativas de um temor de que:

(...) o apoio aberto à promoção e proteção dos direitos humanos possa significar enfraquecimento de suas posições conservadoras em campanhas eleitorais, ou ainda a extensão de direitos, muitas vezes considerados privilégios, a parcelas da população que, segundo eles, não se enquadrariam na categoria de "cidadãos de bem"

Frente à tensão social que, com isso, manifesta-se no cotidiano, enfraquecem as perspectivas de solução - para Adorno, ingênuas e, mesmo, inviáveis - que passam pela grande "mesa de negociação" composta de hommes de bonne volonté ${ }^{125}$. Pois tem passado, sim, pelo autoritarismo da imposição, pela violência policial, onde questões "ligadas a deficits de cidadania e igualdade, sendo cidadania aqui entendida como acesso a bens fundamentais da vida comum, são, normalmente, tratadas como questões de política de segurança pública"126. Enviesam-se, também, na solução cooptadora cínica, quando, percebendo o impacto de novas forças:

(...) a categoria estamental as amacia, domestica, embotando-lhe a agressividade transformadora para incorporá-las a valores próprios, muitas vezes mediante a adoção de uma ideologia diversa, desde que compatível com o esquema de domínio. As respostas às exigências assumem o caráter transacional, de compromisso, até que o eventual antagonismo dilua, perdendo a cor própria e viva, numa mistura de tintas que apaga os tons ardentes ${ }^{127}$.

3.2. Do outro lado, fica a maioria da população, historicamente mantida, tanto quanto possível, na menoridade $e^{128}$, afastada dos processos políticos de formação da vontade, e

${ }^{123}$ RIBEIRO, O povo brasileiro, 2006, p. 226.

${ }^{124}$ NÚCLEO DE ESTUDOS DA VIOLÊNCIA (NEV/USP). 4 ${ }^{\circ}$ Relatório nacional sobre os direitos humanos no Brasil. São Paulo: Universidade de São Paulo/Núcleo de Estudos da Violência, 2010, p. 12. Disponível em: http://www.nevusp.org/downloads/down248.pdf. Acesso em 04/10/2012.

${ }_{125}$ ADORNO, Theodor W. Escritos sociológicos I. Obras completas 8. Trad. Agustín González Ruiz. Madrid/Espanha: Akal, 2004, p. 132 e 425.

${ }_{126}$ BITTAR, O direito na pós-modernidade, 2009, p. 250.

${ }^{127}$ FAORO, Os donos do poder, 1995, p. 745.

${ }^{128}$ DEMO, Cidadania menor, 1992, p. 108. 
integrada ao mercado de trabalho e de consumo, em proveito dos empreendimentos econômicos:

Ontem, era uma força de trabalho escrava de uma empresa agromercantil exportadora. Hoje, é uma oferta de mão de obra que aspira a trabalhar e um mercado potencial que aspira a consumir. Nos dois casos, foi sempre uma empresa próspera, ainda que só o fosse para minorias privilegiadas. Como tal manteve o Estado e enriqueceu as classes dominantes ao longo dos séculos, beneficiando também os mercadores associados ao negócio e as elites de proprietários e burocratas locais ${ }^{129}$.

Não que se negue, absolutamente, a movimentação e organização da sociedade civil, por vezes violenta, exercendo pressões e ativando conflitos sociais. Observam-se, inclusive, na história recente do Brasil, mobilizações que, ainda que se tenha de anotar o caráter esporádico e sobrevivência aos "espasmos",130, notabilizaram-se pelo grande porte, em nível nacional: o movimento das Diretas Já, entre 1983 e 1984; o movimento dos Caras Pintadas, exigindo o "impeachment” do então Presidente da República, Fernando Collor de Mello, em 1992; e, mais recentemente, em junho de 2013, os protestos que, tendo por estopim o aumento de passagens de ônibus, tomaram as ruas de diversas cidades do país numa profusão de pautas - mais educação, mais saúde, o fim da corrupção, dentre outras -, captando, assim, um sentimento social de insatisfação generalizada ${ }^{131}$. Tais "momentos de fusão" caracterizaram-se pelas referências comuns e vínculos abrangentes entre diferentes grupos sociais, no sentido de uma unidade de ação ${ }^{132}$. São reveladores da capacidade de "vibração" da esfera pública em repouso ${ }^{133}$ e, com isso, de seu poder comunicativo, conforme destaca Habermas, citando Hannah Arendt: "O poder que surge entre homens quando agem em conjunto, desaparecendo tão logo eles se espalham"

Porém, constitui, ainda, a referência da experiência política nacional, a centralidade do Estado, polo condutor da sociedade, e não a organização da sociedade civil. O histórico peso e opressão do Estado a moldar a nação ${ }^{135}$. Forjou-se, desse modo, uma cidadania que,

\footnotetext{
${ }^{129}$ RIBEIRO, O povo brasileiro, 2006, p. 229.

${ }^{130}$ DEMO, Cidadania menor, 1992, p. 101.

131 SAFATLE, Vladimir. Sem partido. Jornal Folha de São Paulo, 25/06/2013. Disponível em http://www1.folha.uol.com.br/colunas/vladimirsafatle/2013/06/1300700-sem-partido.shtml. Acesso em 26/06/2013; INSTITUTO DE PESQUISA DATAFOLHA. Protestos sobre o aumento de tarifa dos transportes II. PO 813688. São Paulo, 18/06/2013. Disponível em: http://datafolha.folha.uol.com.br/opiniaopublica/2013/06/1297619-cresce-apoio-a-protestos-contra-a-tarifade-onibus-entre-paulistanos.shtml. Acesso em 26/06/2013.

${ }^{132}$ SOUSA JUNIOR, José Geraldo. Sociologia jurídica: condições sociais e possibilidades teóricas Porto Alegre: Sergio Antonio Fabris Editor, 2002, p. 64.

${ }^{133}$ HABERMAS, Direito e democracia, vol. II, 2011, p. 114.

${ }^{134}$ HABERMAS, Direito e democracia, vol. I, 2012, p. 185 e 186.

${ }^{135}$ RICUPERO, Sete lições sobre as interpretações do Brasil, 2008, p. 168.
} 
na aprendizagem e na experimentação da democracia, efetiva-se menos por meio da participação social nos processos decisórios; mais através do relacionamento parasitário com o governo. O cidadão alquebrado em súdito, pedinte, "quer proteção, não quer participar da vontade coletiva". Enquanto isso, "o Estado mantém a menoridade popular, sobre ela imperando"136.

A valorização do Estado, notadamente do Poder Executivo, e a fascinação diante do líder político projeta-se, na história do país, na identificação deste com o messias, o salvador da pátria ${ }^{137}$. O chefe de governo é confundido com o taumaturgo que, com fórmulas mágicas e, principalmente, rápidas, "remediará todos os males e mitigará todos os sofrimentos" ${ }^{, 138}$.

De forma ambígua, a sociedade civil, no plano da igualdade fundamental entre cidadãos, identifica-se com o líder paternalista, populista. Representado, porém, com Freud, pela figura do great little man, este aparece como alguém que, se sugere a "ideia de que é apenas um de nós", indica também sua onipotência ${ }^{139}$. Mantém-se, assim, com ele, ao mesmo tempo, na assimetria típica a todo paternalismo, uma relação de dependência e proteção $^{140}$, novamente com Freud, na horda conduzida por um chefe $e^{141}$.

Tal herança fica evidenciada em nosso sistema constitucional "hiperpresidencialista" "robustecido de competências presidenciais no processo legislativo", destacando-se, além das atribuições de edição de leis delegadas e de iniciativa, sanção e veto de projetos de leis, a competência para a expedição de medidas provisórias, atos normativos com força de lei (Artigos 62, 66 e 68, da Constituição Federal). Aparece, também, na desvalorização de momentos e instrumentos fundamentais da democracia representativa e direta. Afinal, o "Importante é a eleição do Presidente da República; os demais espaços de participação pública são irrelevantes ou, pior, perfeitamente dispensáveis" $" 142$.

\footnotetext{
${ }^{136}$ FAORO, Os donos do poder, 1995, p. 740 e 744.

${ }^{137}$ CARVALHO, Cidadania no Brasil, 2010, p. 221 e 222.

${ }^{138}$ FAORO, Os donos do poder, 1995, p. 740.

${ }^{139}$ ADORNO, Theodor. W. A teoria freudiana e o padrão da propaganda fascista. Margem esquerda: ensaios marxistas $\mathrm{n}^{\mathrm{o}}$ 07, 2006, p. 177.

${ }^{140}$ WEFFORT, O populismo na política brasileira, 2003, p. 82 e 83.

${ }^{141}$ FREUD, Sigmund. Psicologia das massas e análise do eu. In Obras completas. Volume 15. Psicologia das massas e análise do eu e outros textos (1920-1923). Trad. Paulo César de Souza. São Paulo: Cia das Letras, 2011, p. 83.

${ }^{142}$ RANIERI, $O$ estado democrático de direito e o sentido da exigência de preparo para o exercício da cidadania, pela via da educação, 2009, p. 384 e 385.
} 
A viabilidade da cidadania, no sentido enriquecido estabelecido no texto constitucional, defronta-se, ainda, com uma experiência construída na preeminência do aparato governamental, personificado no líder político, com traços messiânicos, mais ou menos acentuados. Exige, desse modo, o enfrentamento de uma cidadania que, em contraste consigo mesma, prevalece, pervertida, como estadania ${ }^{143}$.

3.3. Nesse contexto, fazendo a ponte frágil entre dois universos apartados - o sistema político e a sociedade civil-, a experiência da democracia, em processo de aprendizagem e consolidação, atualiza-se, preponderantemente, dentro de um conceito políticorepresentativo formal, conformado ao exercício isolado e obrigatório do voto, nas eleições periódicas.

É difícil se falar, num quadro tal de inexperiência democrática, marcado por tantos vícios herdados do passado, em maturidade para a implantação, na linha do ideal democrático de Habermas e Dewey, de uma sociedade civil com forte e constante iniciativa e atuação na captação de problemas sociais, e com plena aptidão para conduzir o debate racional na esfera pública. Enfim, há, ainda, um longo caminho a se percorrer até que se possa afirmar um público consistente de atores sociais que promovam interpretações públicas das experiências e questões que afetam a coletividade, de modo a direcionar as soluções institucionalizadas, no âmbito do direito, pelos órgãos do governo ${ }^{144}$.

A participação popular através dos canais institucionais, previstos no Art. 14 da Constituição Federal, para intervenção direta na legislação e nas políticas governamentais $^{145}$, é quase inexistente. Limitam-se aos seguintes números, no nível federal:

i) Referendo. Houve apenas um, ocorrido em 2005. Tinha por objetivo a consulta da população brasileira sobre a proibição ou não do comércio de armas de fogo e munições no país. A alteração proposta ao Art. 35 do Estatuto do Desarmamento (Lei n⿳ำ 10.826/2003), que estabelecia tal proibição, foi rejeitada.

\footnotetext{
143 CARVALHO, Cidadania no Brasil, 2010, p. 220 e 221.

${ }^{144}$ HABERMAS, Direito e democracia, vol. II. 2011, p. 23, 92 e 100.

${ }^{145}$ BENEVIDES, A cidadania ativa, 2003, p. 12.
} 
ii) Plebiscito. Também só ocorreu um, em 1993, conforme determinava o Art. $2^{\underline{0}}$ dos Atos de Disposições Constitucionais Transitórias. Teve por objetivo a definição da forma (república ou monarquia constitucional) e do sistema de governo (presidencialismo ou parlamentarismo) a vigorar no país. Prevaleceu, em conformidade com o legado de valorização do Poder Executivo forte ${ }^{146}$, a república presidencialista.

iii) Lei de iniciativa popular. Restringem-se a quatro. Destaca-se, contudo, que, na realidade, todas essas leis foram "adotadas" por um "autor", antes da tramitação no Congresso Nacional. Nesse sentido, sua aprovação não se efetivou, rigorosamente, seguindo o processo legislativo aplicável, previsto no Art. 61, $2^{\underline{0}}$, da Constituição Federal, no qual tal "adoção" por um congressista estaria dispensada.

São elas: a) Lei nº 8.930/1994, que alterou a Lei dos Crimes Hediondos, incluindo, nesta modalidade de crime, o "homicídio (art. 121), quando praticado em atividade típica de grupo de extermínio, ainda que cometido por um só agente, e homicídio qualificado (art. 121, § $2^{\mathrm{o}}$, I, II, III, IV e V)". Contou com forte apoio de movimento criado por escritora de telenovelas, Glória Perez, após o assassinato de sua filha. Contudo, foi enviada ao Congresso Nacional pelo então Presidente Itamar Franco, constando, assim, como de autoria do Poder Executivo; b) Lei no 9.840/1999, cuja iniciativa popular, visando a "coibir com mais eficácia o crime da compra de votos de eleitores", foi promovida pela Comissão Brasileira Justiça e Paz - CBJP e pela Conferência Nacional dos Bispos do Brasil - CNBB, com o apoio de dezenas de associações ${ }^{147}$. Tramitou, porém, como projeto de autoria do Deputado Federal Albérico Cordeiro; c) Lei $n^{0}$ 11.124/2005, que criou o Fundo Nacional de Moradia Popular e o Conselho Nacional de Moradia Popular. O projeto, apresentado sob o patrocínio do Movimento Popular de Moradia, foi “adotado" pelo Deputado Federal Nilmário Miranda; e d) Lei Complementar n⿳ 135/2010, a intitulada "Lei da Ficha Limpa". Em que pese sua aprovação tenha sido objeto de pressão da sociedade civil, não se trata, tal

${ }^{146}$ CARVALHO, Cidadania no Brasil, 2010, p. 221.

${ }^{147}$ BRASIL. CÂMARA DOS DEPUTADOS. Combatendo a corrupção eleitoral. Tramitação do primeiro projeto de lei de iniciativa popular aprovado pelo Congresso Nacional. Série Ação Parlamentar, no 96. Brasília: Centro de Documentação e Informação, 1999. Disponível em: http://bd.camara.gov.br/bd/bitstream/handle/bdcamara/1942/combatendo_corrupcao_eleitoral.pdf?sequence= 1. Acesso em 03/10/2012. 
como as anteriores, tecnicamente, em decorrência da forma como tramitou, de lei de iniciativa popular $^{148}$.

Soma-se a essa fragilidade do exercício da participação popular direta, pelos instrumentos disponibilizados pela Constituição Federal, as mazelas e desvirtuamentos do aspecto representativo da prática democrática prevalecente no país.

O cidadão brasileiro desconfia dos processos políticos e de seus agentes. Ele:

(...) pode ser ignorante e acreditar nos milagres de um "salvador da pátria". No outro extremo, pode ser politizado e participar de movimentos populares na defesa de interesses coletivos. Mas, decididamente, não confia nos "representantes do povo". O que, sem dúvida, não é bom para a democracia $^{149}$.

E se mantém afastado dos partidos políticos, instituições com a função legal precípua de "assegurar, no interesse do regime democrático, a autenticidade do sistema representativo" (Art. 1ํㅡㄹ da Lei $\mathrm{n}^{\mathrm{o}}$ 9.096/1995). Embora atuem como "protagonistas quase que exclusivos do jogo político"150, os partidos estão desacreditados pela sociedade civil $^{151}$. Dados do Superior Tribunal Eleitoral demonstram que, em 2012, apenas 10,7\% do eleitorado brasileiro era filiado a tal instituição fundamental ao exercício da democracia representativa - filiação que, destaca-se, não significa, necessariamente, a atuação políticopartidária $^{152}$.

Nesse contexto, a participação política do cidadão reduz-se, em grande medida, à escolha entre dois ou três nomes, apresentados pelos partidos nos quais não se envolve e que, impregnados pela "ética governista" de que se falou, não se distinguem, com precisão, no que se refere a suas orientações e diretrizes político-ideológicas.

Os representantes eleitos, por sua vez, desresponsabilizam-se e desvinculam-se de seus eleitores. A "representação", no Brasil, é tocada, fortemente, pela ideia de "mandato livre e independente", ou seja, "de que os representantes, ao serem eleitos, não têm

148 Informações disponíveis no site da Câmara dos Deputados: http://www2.camara.leg.br. Acesso em $19 / 09 / 2014$.

${ }^{149}$ BENEVIDES, A cidadania ativa, 2003, p. 25.

${ }^{150}$ SILVA, Curso de direito constitucional positivo, 2010, p. 145.

151 Segundo pesquisa por amostragem, realizada pelo Instituto Datafolha, em 2013, com moradores do município de São Paulo, sobre a admiração e o respeito provocado pelos partidos políticos: $44 \%$ da população os consideram sem nenhum prestígio, enquanto $35 \%$ atribuem-lhes pouco prestígio (INSTITUTO DE PESQUISA DATAFOLHA. Protestos sobre aumento na tarifa dos transportes II, 2013).

152 Dados do Superior Tribunal Eleitoral, disponíveis em: http://www.tse.jus.br/eleicoes/estatisticas/estatisticas-eleicoes-2012. Acesso em 07/08/2012. 
nenhuma obrigação, necessariamente, para com as reivindicações e os interesses de seus eleitores" 153 . Eis uma das principais deficiências da democracia representativa no país: a "total ausência de responsabilidade efetiva dos representantes perante o povo" $"$ ".

Quanto à ligação com o eleitorado passivo e desconfiado, ocorre notadamente nos períodos eleitorais, no interesse da (re)eleição. E isso no âmbito de uma esquizofrenia política, alimentada, num mutualismo perverso e nada republicano, pelo clientelismo e favoritismo estatal, de um lado; de outro, por pretensões corporativas, privadas - os interesses dos banqueiros, dos empresários, deste e daquele grupo econômico ou político ou sindicato, etc. -, e mesmo pessoais, uma em detrimento das outras. Todas, nessa medida, em detrimento da solução conjunta e discursiva (dialógica) de questões públicas. Nesse processo, os eleitores, céticos em relação aos procedimentos democráticos e às necessárias reformas sociais, continuam votando nos seus "representantes", na esperança na obtenção de vantagens e favores específicos ${ }^{155}$.

Enfim, num cenário em que os atores sociais agem estrategicamente, interagindo a partir da perspectiva do cálculo de ganho egocêntrico e influenciando-se a partir de promessas, ameaças, influências e bens ${ }^{156}$, a representação e, em última análise, a própria experiência republicana e democrática negam-se a si mesmas. Afinal, desabilitam-se dos recursos ao debate e do convencimento racional, na esfera pública, da persuasão sobre ideias e propostas políticas ${ }^{157}$. Não se orientam dialogicamente pela coisa pública.

Amparadas no uso do poder econômico e na despolitização da esfera pública - em que campanhas eleitorais assumem, com frequência, acriticamente, coloração de marketing de venda de um produto no mercado consumidor - podem se renovar na intermediação dos interesses de grupos específicos, no voto em troca de promessas de benefícios pessoais ou, simplesmente, indefinida a linha divisória entre a "falsidade deliberada e a mensagem política" ${ }^{158}$, no engodo.

\footnotetext{
${ }^{153}$ BERCOVICI, Tentativa de instituição da democracia de massas no Brasil, 2009, p. 378.

154 BENEVIDES, A cidadania ativa, 2003, p. 25.

155 CARVALHO, Cidadania no Brasil, 2010, p. 223 e 224;

156 HABERMAS, Jürgen. Consciência moral e agir comunicativo. Trad. Guido A. de Almeida. $2^{-}$ed. Rio de Janeiro: Tempo brasileiro, 2003, p. 164 e 165.

${ }_{157}^{15}$ DEWEY, The public and its problems, 1991, p. 207.

${ }^{158}$ FERRAZ JUNIOR, Responsabilidade sem culpa, culpa sem responsabilidade na sociedade tecnológica, 2011, p. 152.
} 
Desse modo, diante da larga inexperiência democrática, a afirmação, no Art. $1^{\underline{0}}$, parágrafo único, da Constituição Federal, do princípio da soberania popular e de seu exercício na forma democrática semidireta, sofre, de uma só vez, dois duros golpes.

Primeiro, sem destoar da tradição constitucional brasileira, a democracia se restringe, em grande medida, ao aspecto da representação: o poder emana do povo, mas é exercido pelo seu representante, no âmbito de uma cidadania meramente eleitoral ${ }^{159}$. Aliás, tal esgotamento da democracia na institucionalização do processo eleitoral - a falácia do eleitorismo ${ }^{160}$ - aparece, de modo paradigmático, na própria definição que a si se dá o Tribunal Superior Eleitoral, responsável pela condução das Eleições no país: "O Tribunal da Democracia" ${ }^{\prime 61}$.

Segundo, com a representação de tal forma viciada, o voto obrigatório, periódico e isolado do cidadão acaba por deturpar-se num ato de "renúncia ao seu direito e ao seu dever de participar"162. O poder, nas mãos do "representante" irresponsável democraticamente, pode, enfim, ficar descolado do seu titular, o povo.

Desse modo, a solenidade da fórmula constitucional termina por encobrir a "eliminação de todo o poder ativo do "soberano",163, num cenário em que se exige hermeneuticamente pouco, muito pouco, para o reconhecimento e adjetivação, como democrática, de uma experiência social e política, inexperiente da democracia. Afinal,

(...) desde que funcionem os partidos, a liberdade de expressão, no seu sentido mais direto e imediato, o governo, os tribunais, a chefia do Estado, desde que tudo isto pareça funcionar harmonicamente, e haja eleições e toda a gente vote, as pessoas preocupam-se pouco com procedimentos gravemente antidemocráticos ${ }^{164}$.

Sem a pressão da sociedade civil organizada, o sistema político pode perpetuar-se, sem perturbação e inábil a aberturas dialogais, seu modo rotineiro e ilegítimo de atuação, pouco sensível, em suas rotinas ordinárias de trabalho, aos problemas sociais, distantes dos gabinetes governamentais ${ }^{165}$.

\footnotetext{
159 RANIERI, $O$ estado democrático de direito e o sentido da exigência de preparo para o exercício da cidadania, pela via da educação. 2009, p. 385.

${ }^{160}$ MOISÉS, Os brasileiros e a democracia, 1995, p. 35.

161 A expressão acompanha a denominação do Tribunal, destacada no site oficial do órgão: “Tribunal Superior Eleitoral: O Tribunal da Democracia”. Disponível em: www.tse.gov.br. Acesso em 24/05/2013.

${ }^{162}$ SARAMAGO, José. As palavras de Saramago: catálogo de reflexões pessoais, literárias e políticas. Sel. e Org. Fernando Gómez Aguilera. Trad. Rosa F. d'Aguiar e outros. São Paulo: Cia das Letras, 2010, p. 384.

${ }^{163}$ COMPARATO, Fábio Konder. Para viver a democracia. São Paulo: Brasiliense, 1989, p. 76.

${ }^{164}$ SARAMAGO, As palavras de Saramago, 2010, p. 384.

${ }^{165}$ HABERMAS, Direito e democracia, vol. 02, 2011, p. 90.
} 
3.4. Intimamente ligada à (in)experiência da democracia, assim configurada historicamente, aparece - e não podia ser diferente -, num ciclo vicioso, a precariedade da cultura dos direitos fundamentais no Brasil.

Afinal, a democracia, amparada nos direitos humanos, é também o espaço fundamental da luta por reconhecimento, ampliação e concretização destes direitos. $\mathrm{O}$ sistema jurídico que assegura o status de sujeito de direito e, nele, uma existência digna, sem a qual o cidadão claudica na experiência da democracia, é construído e afirmado por meio da participação ativa da cidadania nessa mesma experiência ${ }^{166}$.

É bem verdade, não podem ser negados os avanços experimentados pela população brasileira, no campo dos direitos fundamentais, no período pós Constituição de 1988. E isso, não só em termos de legislação, mas também de políticas e de ações das esferas governamentais e das organizações da sociedade civil em sua efetivação ${ }^{167}$. Aliás, com os Planos Nacionais de Direitos Humanos (Decretos Federais n $\mathrm{n}^{\text {os }}$ 1.904/1996, 4.229/2002 e 7.037/2009), estes adquiriram, no país, o status de política pública, "Vale dizer, a proteção aos direitos humanos não é mais concebida como fruto do acaso, como um incidente de percurso, mas passa a ser objeto de planejamento governamental"168.

Contudo, passados mais de vinte e cinco anos da promulgação da Constituição, a aprendizagem da democracia, a partir de sua própria experiência incipiente, convive, ainda, com uma realidade que reflete de modo bastante distorcido os direitos fundamentais constitucionalmente reconhecidos:

Ainda há muito para ser conquistado em termos de respeito à dignidade
da pessoa humana, sem distinção de raça, nacionalidade, etnia, gênero,
classe social, região, cultura, religião, orientação sexual, identidade de
gênero, geração e deficiência. Da mesma forma, há muito a ser feito para
efetivar o direito à qualidade de vida, à saúde, à educação, à moradia, ao

${ }^{166}$ COMITÊ NACIONAL DE EDUCAÇÃO EM DIREITOS HUMANOS, Plano Nacional de Educação em Direitos Humanos, 2007, p. 24; HABERMAS, Direito e democracia, vol. 01, 2012, p. 159; HABERMAS, Direito e democracia, vol. 02, 2011, p. 41.

${ }^{167}$ NÚCLEO DE ESTUDOS DA VIOLÊNCIA (NEV/USP). $5^{\underline{0}}$ Relatório nacional sobre os direitos humanos no Brasil (2001-2010). São Paulo: Universidade de São Paulo/Núcleo de Estudos da Violência, 2012, p. 10. Disponível em: http://www.usp.br/imprensa/wp-content/uploads/5\%C2\%BA-Relat\%C3\%B3rioNacional-sobre-os-Direitos-Humanos-no-Brasil-2001-2010.pdf. Acesso em 21/05/2014.

${ }^{168}$ PIOVESAN, Temas de direitos humanos, 2003, p. 346. 
lazer, ao meio ambiente saudável, ao saneamento básico, à segurança pública, ao trabalho e às diversidades cultural e religiosa, entre outras ${ }^{169^{3}}$.

A análise, ainda que superficial do contraposto fático dos direitos fundamentais, no Brasil, são suficientes para revelar um retrato preocupante da situação nacional.

Com efeito, a inviolabilidade do direito humano mais primordial, a vida, torna-se falácia diante de uma taxa nacional de mortalidade por homicídios, em 2012, de 29 por 100 mil habitantes, num total de 56.337 homicídios $^{170}$. O número, comparável a de uma guerra civil, impressiona quando comparado a de países como os Estados Unidos, em que a taxa está em torno de cinco, e à França, em que não chega a dois homicídios ${ }^{171}$.

Essa realidade se mostra mais cruel quando se observa a participação considerável, na composição da taxa, de homicídios decorrentes de violência policial, isto é, do assassinato sistemático cometido pelo Estado anistiado pelos crimes praticados durante duas décadas de Ditadura Militar. Reminiscência do autoritarismo, orientado, agora, pelo critério da vulnerabilidade socioeconômica ${ }^{172}$. Dados da Relatoria Especial da ONU para Execuções extrajudiciais, Sumárias ou Arbitrárias constatam que, em 2007, 18\% dos homicídios ocorridos no Estado do Rio de Janeiro haviam sido cometidos pela Polícia ${ }^{173}$. No Estado de São Paulo, dados da Secretaria de Segurança Pública revelam que, entre 2001 e 2011, as polícias paulistas (Militar e Civil) mataram juntas, "em serviço", 5591 pessoas, uma média de 508 pessoas por ano ${ }^{174}$.

Soma-se a isso, no âmbito da sociedade marcada pela "desigualdade fundamental" 175 , a vida vivida indignamente por grande parcela da população, sem a garantia do mínimo existencial ${ }^{176}$.

${ }^{169}$ COMITÊ NACIONAL DE EDUCAÇÃO EM DIREITOS HUMANOS, Plano Nacional de Educação em Direitos Humanos, 2007, p. 23.

${ }^{170}$ WAISELFISZ, Julio Jacobo. Mapa da violência 2014. Os jovens do Brasil. Versão Preliminar. Rio de Janeiro: $\quad$ FLACSO/Brasil, $2014 . \quad$ Disponível em: http://www.mapadaviolencia.org.br/pdf2014/Mapa2014 JovensBrasil_Preliminar.pdf. $\quad$ Acesso em 20/10/2014.

${ }^{171}$ NÚCLEO DE ESTUDOS DA VIOLÊNCIA (NEV/USP), $4^{-}$Relatório nacional sobre os direitos humanos no Brasil, 2010, p. 09.

${ }_{172}$ PIOVESAN, Temas de direitos humanos, 2003, p. 348 e 349.

${ }^{173}$ NÚCLEO DE ESTUDOS DA VIOLÊNCIA (NEV/USP), 4º Relatório nacional sobre os direitos humanos no Brasil, 2010, p. 10.

${ }^{174}$ CUBAS, Viviane de Oliveira. Violência policial em São Paulo (2001-2011). In NÚCLEO DE ESTUDOS DA VIOLÊNCIA (NEV/USP), $5^{o}$ Relatório nacional sobre os direitos humanos no Brasil (2001-2010), 2012, p. 114.

${ }_{175}$ BENEVIDES, A cidadania ativa, 2003, p. 194.

${ }^{176}$ SARLET, Dignidade da pessoa humana e direitos fundamentais na Constituição Federal de 1988, 2011, p.111. 
Pois, enquanto o grupo populacional dos $10 \%$ mais ricos concentra em torno de $44 \%$ da riqueza nacional, o contingente dos $10 \%$ mais pobres detém não mais que $1 \%$ da renda do país. O crescimento econômico do país, que chegou a alçá-lo à condição de $6^{\mathrm{a}}$ economia mundial, em 2012, em termos de produto interno bruto, contrasta, ainda, com outro Brasil, da perversa desigualdade na distribuição da renda, no qual metade das famílias sobrevive com rendimento mensal per capita não superior ao salário-mínimo ${ }^{177}$.

Feito o recorte da desigualdade da renda, tomando como referência o gênero e a cor da pele, salta aos olhos, também, a discriminação sofrida, no Brasil, por mulheres e negros ou pardos. O rendimento mensal da população feminina é, em média, $40 \%$ inferior à da masculina; já o da população negra e parda é aproximadamente $45 \%$ menor do que o da

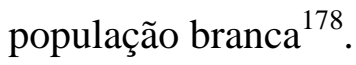

A exclusão e desigualdade aparecem refletidas, também, no desrespeito aos direitos sociais.

Nesse sentido, citam-se, a título de exemplo, as dificuldades enfrentadas pela população que necessita dos serviços públicos de saúde, como a falta de médicos e as longas filas para o atendimento ${ }^{179}$; o déficit habitacional brasileiro, em torno de cinco milhões de moradias $(8,53 \%)^{180}$; e os graves problemas nacionais de saneamento básico, direito que, elementar em termos de qualidade de vida, embora não previsto expressamente no Art. $6^{\mathrm{o}}$ da Constituição Federal, não pode ser descolado dos direitos sociais, diante forma que os afeta, em seu conjunto ${ }^{181}$. E, em relação a este tema, impressiona que mais da metade dos domicílios brasileiros (56\%) nem sequer tem acesso ao serviço de esgotamento sanitário por rede coletora, considerado o sistema apropriado. Na região Nordeste, o

177 NÚCLEO DE ESTUDOS DA VIOLÊNCIA (NEV/USP), $4^{\circ}$ Relatório nacional sobre os direitos humanos no Brasil, 2010, p. 15 e 16.

${ }_{178}$ NÚCLEO DE ESTUDOS DA VIOLÊNCIA (NEV/USP), 4º Relatório nacional sobre os direitos humanos no Brasil, 2010, p. 21 a 23.

${ }^{179}$ INSTITUTO DE PESQUISA ECONÔMICA APLICADA (IPEA). Sistema de Indicadores de Percepção Social (SIPS). Saúde. Brasília, 2011, p. 15. Disponível: http://www.ipea.gov.br/portal/images/stories/PDFs/SIPS/110207_sipssaude.pdf. Acesso em 22/05/2014.

${ }^{180}$ LIMA NETO, Vicente Correia e outros. Nota Técnica $n^{\circ}$ 05. Estimativas do déficit habitacional brasileiro (PNAD 2007-2012). Brasília: IPEA, novembro/2013, p. 02 a 04. Disponível em: http://www.ipea.gov.br/portal/images/stories/PDFs/nota tecnica/131125 notatecnicadirur05.pdf. Acesso em 21/05/2014. Conforme esclarece a Nota Técnica, o indicador afere a necessidade de incremento do estoque de moradias, incapaz de atender dignamente a população, tendo por componentes: habitações precárias, coabitação familiar; ônus excessivo de aluguel; e adensamento excessivo de domicílios locados.

181 INSTITUTO BRASILEIRO DE GEOGRAFIA E ESTATÍSTICA (IBGE). Pesquisa Nacional de Saneamento Básico - PNSB 2008. Rio de Janeiro, 2010, p. 40. Disponível em: http://www.ibge.gov.br/home/estatistica/populacao/condicaodevida/pnsb2008/PNSB_2008.pdf. Acesso em 20/10/2012. 
acesso se limita a aproximadamente $22 \%$; na região Norte, não chega a 4\%. E a estatística não responde sobre a qualidade do serviço ou "se o esgoto, depois de recolhido, é tratado" 182 .

Por fim, o direito à educação, na modalidade privilegiada pelo Estado, a escolar ${ }^{183}$.

Não obstante o supramencionado "sofisticado e singular arcabouço jurídico de proteção, promoção e garantia"184, e, reconheça-se, os avanços experimentados, notadamente em termos quantitativos, a situação nacional é ainda preocupante.

O Brasil está perto de cumprir, com atraso, a meta de universalização do ensino fundamental, conforme o objetivo previsto no Plano Nacional de Educação 2001-2010 (Lei $\mathrm{n}^{\mathrm{o}}$ 10.172/2001). Atende em torno de $98 \%$ das crianças e adolescentes dos seis aos quatorze anos. Entretanto, estendido, por meio da Emenda Constitucional n ${ }^{0}$ 59/2009, o direito público subjetivo ao ensino obrigatório e gratuito às crianças dos quatro aos dezessete anos, o retrato fica mais incômodo. A taxa de escolarização dessa faixa da população não supera $92 \%{ }^{185}$.

O problema educacional brasileiro, porém, não se limita a este dado quantitativo. Resultados apresentados, pelo país, na avaliação do Programa PISA - como mencionado na Introdução - e, ainda, no âmbito do Indicador de Alfabetismo Funcional (INAF) Brasil $2011^{186}$ revelam a grave fragilidade qualitativa da escola brasileira, frente à tarefa mais elementar de ensinar a ler e escrever.

Segundo o Indicador citado, $27 \%$ da população brasileira na fixa etária dos 15 aos 64 anos são analfabetas funcionais. Isto é, são absolutamente analfabetas ou dispõem apenas de um nível rudimentar de alfabetismo ${ }^{187}$. E o que é pior: permanecem com a

182 INSTITUTO BRASILEIRO DE GEOGRAFIA E ESTATÍSTICA (IBGE). Pesquisa Nacional de Saneamento Básico - PNSB 2008. Rio de Janeiro, 2010, p. 40 e 41.

${ }^{183}$ SAVIANI, A nova lei da educação, 2004, p. 03.

${ }^{184}$ RANIERI, $O$ estado democrático de direito e o sentido da exigência de preparo para o exercício da cidadania, pela via da educação, 2009, p. 380.

${ }^{185}$ Dados oficiais, referentes ao Censo Demográfico 2010, compilados pela organização não governamental Todos pela Educação. Disponível em: http://www.todospelaeducacao.org.br/educacao-no-brasil/numeros-dobrasil/brasil/?ano=2011. Acesso em 25/05/2013.

186 AÇÃO EDUCATIVA/INSTITUTO PAULO MONTENEGRO. INAF BRASIL 2011: Indicador de Alfabetismo Funcional. Principais resultados. São Paulo, 2012. Disponível em: http://www.ipm.org.br/download/informe resultados_inaf2011_versao\%20final 12072012b.pdf. Acesso em 04/08/2012.

${ }^{187} \mathrm{O}$ Indicador trabalha com quatro níveis de alfabetismo: i) analfabetismo, que "corresponde à condição dos que não conseguem realizar tarefas simples que envolvem a leitura de palavras e frases ainda que uma parcela destes consiga ler números familiares (números de telefone, preços, etc.)"; ii) nível rudimentar, que indica a "capacidade de localizar uma informação explícita em textos curtos e familiares (...), ler e escrever 
condição de analfabetos funcionais $26 \%$ da população que completa o ensino fundamental, $8 \%$ dos que concluem o ensino médio e, pasme-se, $4 \%$ dos que concluem o ensino superior. Ainda em relação à faixa com formação superior, apenas $62 \%$ são alfabetizados num nível pleno ${ }^{188}$.

Assim conformada, a cidadania que atualizaria o Estado Democrático de Direito é marcada por graves violações e a sobrevivência de problemas históricos de desigualdade e de exclusão social ${ }^{189}$. Enfrenta, ainda, o desrespeito aos direitos mais básicos, indispensáveis à constituição digna da pessoa, como sujeito de direito, capaz de participar ativa e racionalmente da vida social.

Na dialética dos progressos experimentados na vivência da democracia, se problemas sociais foram superados, outros se mantiveram, muitos se agravaram. E o Brasil convive, ainda, com a desigualdade, a pobreza extrema, a violência, a oferta inadequada de serviços públicos de saúde, educação, saneamento básico, dentre outros ${ }^{190}$. Tudo a dificultar a consolidação daquela ambiência democrática que, superando a deturpação meramente formal-representativa atual, poderia alavancar a solução de tantas mazelas e injustiças sociais.

\section{Experiência, educação e democracia}

Eis, afinal, o lugar a partir do qual se fala. Efeito de continuidade experiencial, instituições, hábitos e práticas ligadas à inexperiência republicana e democrática - a tradição do autoritarismo, do não-diálogo, do paternalismo, do patrimonialismo e do

números usuais e realizar operações simples, como manusear dinheiro para o pagamento de pequenas quantias ou fazer medidas de comprimento usando fita métrica"; iii) nível básico, no qual as pessoas são consideradas funcionalmente alfabetizadas, "pois já leem e compreendem textos de média extensão, localizam informações mesmo que seja necessário realizar pequenas inferências, leem números na casa dos milhões, resolvem problemas envolvendo uma sequência simples de operações e têm noção de proporcionalidade"; iv) nível pleno, em que as pessoas não encontram óbices para compreender e interpretar textos em situações usuais; "leem textos mais longos, analisando e relacionando suas partes, comparam e avaliam informações, distinguem fato de opinião, realizam inferências e sínteses. Quanto à matemática, resolvem problemas que exigem maior planejamento e controle, envolvendo percentuais, proporções e cálculo de área, além de interpretar tabelas de dupla entrada, mapas e gráficos" (AÇÃO EDUCATIVA/INSTITUTO PAULO MONTENEGRO, INAF BRASIL 2011, 2012, p. 04).

${ }^{188}$ AÇÃO EDUCATIVA/INSTITUTO PAULO MONTENEGRO, INAF BRASIL 2011, 2012, p. 07.

189 NÚCLEO DE ESTUDOS DA VIOLÊNCIA (NEV/USP), 4º Relatório nacional sobre os direitos humanos no Brasil, 2010, p. 09.

${ }^{190}$ CARVALHO, Cidadania no Brasil, 2010, p. 08. 
desrespeito aos direitos humanos - permanecem vivas sob a nova ordem constitucional, limitando e maculando, no âmbito da sociedade injusta e desigual, o alcance das transformações ${ }^{191}$.

Atualizam-se como herança que contradiz a interação social, na esfera pública, como espaço de diálogo, do convencimento e do entendimento racional, sem o que é impensável a democracia ${ }^{192}$. Desabilitam o cidadão à participação, em igualdade de condições, na solução de problemas comuns e na formação racional da vontade. Repetem a experiência da democracia reduzida ao momento eleitoral, o eleitorismo ${ }^{193}$. Renovam o sistema político alheio e irresponsável em relação à sociedade civil que lhe cumpriria representar $^{194}$. Degeneram laços sociais de solidariedade, no âmbito da sociedade individualista, aberta à "linguagem" da violência" ${ }^{195}$, quase hobbesiana, na qual, na expressão de Milton Friedman, não se reconhece nenhum objetivo comum "a não ser o conjunto de propósitos pelos quais os cidadãos lutam separadamente" ${ }^{\text {"196 }}$. Promove, na desilusão quanto à eficácia dos procedimentos democráticos para as necessárias reformas sociais ${ }^{197}$, o líder paternalista e taumaturgo, com soluções prontas e rápidas ${ }^{198}$.

No ciclo vicioso em que, em termos de efetividade, menos de direitos humanos implicou menos democracia e menos democracia acarretou menos direitos humanos, o Estado Democrático de Direito, amparado juridicamente em vigoroso rol de direitos fundamentais, não se realizou só com a promulgação técnico-jurídica (ainda que, ressaltase, dela não prescinda). E parece certo, também, que, abandonadas as metanarrativas que prediziam a história, não se constituirá como reflexo necessário de uma "suposta necessidade histórica" $" 199$.

Diante de uma experiência antidialógica, é de se esperar que a maioria oprimida "hospede" dentro de si a antipatia pelo diálogo. Faz perdurar, no horizonte existencial, determinado pelas próprias experiências, "a sombra testemunhal do antigo opressor", que

\footnotetext{
${ }^{191}$ MOISÉS, Os brasileiros e a democracia, 1995, p. 27.

${ }^{192}$ WEFFORT, Por que democracia?, 1984, p. 46; BENEVIDES, A cidadania ativa, 2003, p. 19.

${ }^{193}$ MOISÉS, Os brasileiros e a democracia, 1995, p. 35.

${ }^{194}$ BERCOVICI, Tentativa de instituição da democracia de massas no Brasil, 2009, p. 378; BENEVIDES, A cidadania ativa, 2003, p. 25.

${ }^{195}$ BITTAR, O direito na pós-modernidade, 2009, p. 250, 257 e 264.

196 FRIEDMAN, Milton. Capitalismo e Liberdade. Trad. Luciana Carli. São Paulo: Abril Cultural, 1984, p. 11.

${ }^{197}$ CARVALHO, Cidadania no Brasil, 2010, p. 08 e 219.

${ }^{198}$ FAORO, Os donos do poder, 1995, p. 744.

${ }^{199}$ WEFFORT, Por que democracia?, 1984, p. 31.
} 
"continua a ser o seu testemunho de "humanidade","200 . Retratando o cotidiano brasileiro da segunda metade do Século XIX, Machado de Assis narra a história do escravo Prudêncio, o “cavalo de todos os dias" do ainda menino Brás Cubas e por ele fustigado. Depois de liberto, teve também o seu escravo, que vergalhava em praça pública: "Era o modo que o Prudêncio tinha de se desfazer das pancadas recebidas - transmitindo-as a outro"201.

Contudo, se na configuração do presente, o peso do passado legado não pode ser subestimado, ele também não lhe empresta a força invencível, "em virtude da qual deveríamos ficar eternamente incapacitados ao exercício mais autêntico da democracia" ${ }^{202}$. A constatação da realidade brasileira e sua inexperiência em termos de democracia, "não significa congelá-la para todo o sempre"203.

$\mathrm{Na}$ incompletude da experiência da democracia, no Brasil, distingue-se a perspectiva hermenêutica do projeto inacabado de modernidade, integrada ao plano constitucional. E isso, dentro de uma abordagem revisionista crítica, que, aprendendo com os erros e desacertos extraídos da história, possibilita reconquistar a tradição moderna emancipatória não realizada ${ }^{204}$.

É nesse sentido, à luz do projeto constitucional promulgado em 1988, que o Estado Democrático de Direito tem de se atualizar e se renovar dinamicamente, num caminho penoso e falível ${ }^{205}$. Eis, afinal, a perspectiva que se assume a partir de uma fundamentação filosófica em John Dewey e Jürgen Habermas.

No continuum experiencial, "Os homens não podem facilmente livrar-se de seus velhos hábitos de pensar e nunca podem livrar-se deles de uma só vez”. Afinal, “Ao desenvolver, ensinar e receber novas ideias, somos compelidos a usar algo das antigas como instrumento de compreensão e comunicação"206.

\footnotetext{
${ }^{200}$ FREIRE. Paulo. Pedagogia do oprimido. 50 $0^{\mathrm{a}}$ ed. Rio de Janeiro: Paz e Terra, 2011, 43 e 45.

201 ASSIS, Machado de. Memórias Póstumas de Brás Cubas. 18ª Ed. São Paulo: Ática, 1992, p. 32, 33 e 101.

${ }^{202}$ FREIRE, Educação como prática de liberdade, p. 89 e 90.

${ }^{203}$ BENEVIDES, A cidadania ativa, 2003, p. 195.

204 BITTAR, Justiça e emancipação, 2011, p. 110; HABERMAS, Jurgen. Modernidade - um projeto inacabado. In ARANTES, Otília B. Fiori e ARANTES, Paulo Eduardo. Um ponto cego no projeto moderno de Jurgen Habermas: arquitetura e dimensão estética depois das vanguardas. São Paulo: Brasiliense, 1992, p. 118; PINZANI, Alessandro. Habermas. Porto Alegre: Artmed, 2009, p. 77.

${ }^{205}$ MOISÉS, Os brasileiros e a democracia, 1995, p. 84; HABERMAS, Direito e democracia, vol. 02, 2011, p. 119; BONAVIDES, Paulo. Curso de Direito Constitucional. 26 ${ }^{\mathrm{a}}$ Ed. atual. São Paulo: Malheiros, 2011 , p. 380 e 381.

${ }^{206}$ DEWEY, John. Reconstruction in philosophy. Mineola/New York: Dover Publication, 2004, p. 43.
} 
A consolidação da democracia não pode senão partir do instituído - o sistema de normas e valores, os padrões culturais e instituições sociais dadas -, trabalhando, a partir dele, com as possibilidades precárias de nosso tempo ${ }^{207}$. Somente pode ser pensada no exercício continuado, ainda que imperfeito, pela cidadania, da própria democracia, valendo-se, assim, do potencial educacional de sua experiência, em que pese as "deformações e negações de nossa realidade política"208.

Passa, necessariamente, pela gradual e progressiva formação de hábitos, práticas e instituições democráticas. Passa pela educação colada à experiência da participação, do diálogo, enfim, da democracia, sob o amparo de direitos humanos.

É ciente de todas as contradições que se estabelecem na experiência social e das condições objetivas do presente "sobrecarregado" que tornam precárias as possibilidades de transformação, que a tese se debruça sobre a educação, o espaço central da modernidade para o esclarecimento, como locus para o esforço da consolidação democrática.

Tal é a aposta para o florescimento daquele fermento contido, daquela rasgadura evitada, referida por Raymundo Faoro, cuja contenção forjou uma civilização "marcada pela veleidade". Uma "claridade opaca, luz coada pelo vidro fosco"; coberta, sobre o esqueleto de ar, pela "túnica do passado inexaurível, pesado, sufocante"209.

A tese se coloca, enfim, diante da questão da medida de nossa impotência: em que ponto deve alquebrar-nos em conformismo; mas, por outro lado, até que ponto desautoriza ao movimento crítico em direção a uma experiência melhor.

${ }^{207}$ MELO, Tarso de. Direitos Sociais e Resistência. Seminário proferido no âmbito da disciplina Direitos Humanos Fundamentais do Programa de Pós-graduação Stricto Sensu da Universidade de São Paulo. São Paulo, 02/05/2011.

${ }^{208}$ DUARTE, A ordem privada e a organização política nacional, 1939, p. 203.

${ }^{209}$ FAORO, Os donos do poder, 1995, p. 748. 


\section{EDUCAÇÃO E DEMOCRACIA NA FILOSOFIA SOCIAL DE JOHN DEWEY}

Em menção que se torna lugar-comum na apresentação de John Dewey, Richard Rorty coloca-o, juntamente com Martin Heidegger e Ludwig Wittgenstein, no seleto trio dos mais importantes filósofos do Século XX. Destaca, no pensamento dos autores, a "mensagem historicista", que rompe com o "tradicional padrão cartesiano-kantiano" da filosofia moderna ${ }^{1}$.

Sem adentrar na questão do acerto de Rorty, em sua eleição, tampouco da adequação dos critérios por ele utilizados para tanto, importa ressaltar que, de par com o reconhecimento da importância de Dewey - não limitada, absolutamente, à tradição do pragmatismo norte-americano, em que se inserem esses dois filósofos -, não caminhou, na ambiência filosófica que lhe sucedeu, a equivalente atenção e compreensão de suas ideias.

\footnotetext{
${ }^{1}$ RORTY, Richard. A filosofia e o espelho da natureza. Trad. Jorge Pires. Lisboa: Publicações Dom Quixote, 1988 , p. 16 e 19.
} 
Dewey, é verdade, exerceu grande influência no cenário filosófico pragmatista de seu país, os Estados Unidos, na primeira metade do século passado ${ }^{2}$. Destacada a deferência ao autor, em especial, na teoria e na prática educacional norte-americana, no período aludido, espraiada à Europa e à América Latina ${ }^{3}$, sobressai como nome que aparece associado à reflexão sobre a educação na sociedade democrática.

Nesse contexto, seu pensamento influenciou, inclusive, os caminhos da educação brasileira. Fez-se presente no movimento da Escola Nova ${ }^{4}$, no país, ativo participante dos debates políticos e legislativos sobre a educação nacional, sobretudo nas décadas de 1930 a 1960. E isso, principalmente, por meio do trabalho de Anísio Teixeira ${ }^{5}$, grande expoente, no Brasil, da filosofia deweyana ${ }^{6}$.

Não obstante, é notável, na história do Século XX, o quanto pesou sobre o pensamento do autor e, em geral, sobre toda tradição filosófica pragmatista - na forma como construída em seu momento inicial -, um misto de desatenção e má-interpretação, mitigados, é verdade, com o recente "ressurgimento" de seus temas e reflexões?.

Tal movimento, vale lembrar, constitui momento relevante, talvez o mais distinto, da história da filosofia norte-americana, remontando a um grupo heterogêneo de pensadores, com presente e destacada atividade intelectual, a partir do final do Século XIX. Inclui, dentre outros, além de Dewey, Charles S. Peirce, William James e George Herbert

${ }^{2}$ BERNSTEIN, Richard J. The resurgence of pragmatism. Social research, vol. 59, no 4, 1992, p. 815.

${ }^{3}$ BENJAMIN, Harold R. W. A educação e o ideal democrático. Trad. Beatriz Osório. Série VII - Cursos e conferências Vol. 02. Rio de Janeiro: Instituto Nacional de Estudos Pedagógicos - INEP/MEC, 1960, p. 30.

${ }^{4}$ Como descreve Moacir Gadotti, a Escola Nova corresponde a um movimento que "foi se construindo junto com a escola moderna, científica e pública. Os escolanovistas não puderam negar as contribuições do positivismo e do marxismo. Daí constituir-se num movimento complexo e contraditório. Não podemos confundi-lo apenas com um movimento liberal" (GADOTTI, Moacir. História das ideias pedagógicas. $8^{\mathrm{a}}$ ed. São Paulo: Ática, 2002, p. 148).

${ }^{5}$ Anísio Teixeira foi aluno de Dewey, tendo se destacado como o principal nome, no Brasil, do movimento da Escola Nova, na linha pragmatista deweyana. Além de sua extensa produção teórica, na temática educacional, importa ressaltar sua atuação como coordenador do então Instituto Nacional de Estudos Pedagógicos - INEP (Hoje, Instituto Nacional de Estudos e Pesquisas Educacionais Anísio Teixeira), de 1952 até o Golpe Militar de 1964, fazendo deste órgão do Ministério da Educação, no período, um espaço privilegiado para a "difusão do ideário pragmatista, difusão essa que se fazia não só através das suas numerosas publicações (inclusive didáticas) e dos cursos e conferências que promovia, mas também das escolas experimentais a ele vinculadas" (MENDONÇA, Ana Waleska P. C. e outros. Pragmatismo e desenvolvimentismo no pensamento educacional brasileiro dos anos de 1950/1960. Revista Brasileira de Educação, v. 11 no 31 jan./abr. 2006, p. 99). Entre essas publicações, citam-se duas conferências que integram as referências bibliográficas desta tese: A educação e o ideal democrático (1960), de Harold Benjamin, e Importância da teoria em educação (1961), de John Brabucher.

${ }^{6}$ GHIRALDELLI JUNIOR, Paulo. Filosofia e história da educação brasileira. Barueri: Manole, 2003, p. 45; SAVIANI, Dermeval. Escola e democracia. Edição comemorativa. Campinas: Autores associados, 2008, p. 41.

7 JOAS, Hans. Pragmatism and social theory. Chicago: University of Chicago Press, 1993, p. 02; BERNSTEIN, The resurgence of pragmatism, 1992, p. 818. 
Mead, com quem Dewey atuou nas Universidades de Michigan (1884-1894) e de Chicago (1894-1904). Aparece como importante referência à perspectiva psicológica incorporada ao seu trabalho ${ }^{8}$.

No entanto, já em meados do século passado, as reflexões centrais do pragmatismo e, dentro dele, o pensamento deweyano, foram relegadas do ambiente acadêmico norteamericano, dominado pela filosofia analítica, pela influência de pensadores, fugidos do nazi-fascismo europeu e ligados ao positivismo lógico do denominado Círculo de Viena 9 .

Deixando de lado a discussão se, nesse momento, teria havido uma verdadeira ruptura com o legado pragmatista ou, tão somente, uma segunda fase do movimento ${ }^{10}$, com a "continuidade, a persistência e o refinamento de temas pragmáticos nos escritos de filósofos 'analíticos' como Quine, Sellars e Davidson”, é de se reconhecer o “considerável estreitamento e limitação do foco" pelo "pragmatismo analítico", comprometido com a acuidade lógica, com elevados padrões de precisão e rigor do pensamento e argumentação. Não se encontram, nessa direção, reflexões mais amplas, centrais nos pragmatistas clássicos, sobre política, ética, educação e filosofia social ${ }^{11}$. Nas décadas que se seguiram, autores como John Dewey acabaram considerados como antiquados e de pequena relevância" ${ }^{12}$ apenas "um resíduo otimista e ingênuo do antigo liberalismo, desacreditado pela Depressão e pelos horrores da Guerra, e praticamente expulso dos departamentos de filosofia pela escola reinante, a filosofia analítica" ${ }^{\text {13 }}$, assumida como herdeira do que de melhor teria havido no pragmatismo ${ }^{14}$.

Nesse sentido, a "versão do pragmatismo de Dewey", mesmo antes da morte do filósofo, em 1952, imergiu, de um modo geral, num período de esquecimento ${ }^{15}$. Jayme

8 BERNSTEIN, The resurgence of pragmatism, 1992, p. 813 e 833; MURARO, Darcísio Natal. A importância do conceito no pensamento deweyano: relações entre pragmatismo e educação. (Doutorado Programa de Pós-graduação em Educação. Área de concentração: Educação e filosofia). Faculdade de Educação da Universidade de São Paulo, 2008, p. 36 e 37.

${ }^{9}$ BERNSTEIN, The resurgence of pragmatism, 1992, p. 815 e 816; HICKMAN, Larry A (ed.). Reading Dewey. Interpretations for a postmodern generation. Bloomington/Indianapolis: Indiana University Press, 1998, p. xii.

${ }^{10}$ GHIRALDELLI JUNIOR, Paulo. Pragmatismo e neopragmatismo. In RORTY, Richard. Para realizar a América. O pensamento de esquerda no Século XX na América. Trad. Paulo Ghiraldelli Jr., Alberto Tosi Rodrigues e Leoni Henning. Rio de Janeiro: DP\&A Editora, 1999, p. 08 e 09.

${ }^{11}$ BERNSTEIN, The resurgence of pragmatism, 1992, p. 823 e 827.

${ }^{12}$ HICKMAN, Reading Dewey, 1998, p. xii.

${ }^{13}$ DICKSTEIN, Morris. Pragmatism Then and Now. In The Revival of Pragmatism: new essays on social thought, law and culture. Durham/London: Duke University Press, 1998, p. 01.

${ }^{14}$ RORTY, Richard. Consecuencias del pragmatismo. Trad. José Miguel Esteban Cloquell. Madrid: Tecnos, 1996, p. 241.

${ }^{15}$ RORTY, Consecuencias del pragmatismo, 1996, p. 241. 
Abreu, referindo-se à "álgida apatia quanto à obra do grande filósofo norte-americano", destacava o "quase anonimato com que passou, no Brasil, o centenário de Dewey", em 1959, incompatível com a "importância de sua obra no campo da filosofia e, particularmente, no da filosofia da educação" ${ }^{\text {"16. }}$.

$\mathrm{E}$, à desatenção, somam-se as constantes distorções nas citações ao autor.

O filósofo é, inclusive, citado como exemplo instrutivo da perda de conteúdo sofrida por teorias formuladas primeiramente de modo sistemático e cuidadoso, em traduções simplistas, fragmentos de impacto, que, no seu caso, "serviram como slogans para novas tendências progressistas da educação norte-americana"17.

Aclamado, por muitos, como o "Filósofo da América"18, Dewey acabou, depois, negligentemente encerrado em reduções desatentas que atingiam, afinal, as linhas filosóficas e pedagógicas a que se ligava, confundidas com vícios da cultura norteamericana na qual radicavam.

As concepções filosóficas do pragmatismo e, conforme se referia, do experimentalismo e do instrumentalismo, defendidas por Dewey, acabaram vinculadas ao "mercantilismo excessivo da vida americana", ao seu individualismo "irrefletido e brutal". Nesse sentido, como destaca o autor, talvez em função de reações irrefletidas a associações verbais ordinárias com as palavras "instrumental" e "prática", foram identificadas com "aspectos da vida americana que fazem da ação um fim em si mesmo e que concebem os fins de maneira estreita”. Isto é, foram deturpadas em racionalidade instrumental e individualista: o uso da razão como instrumento para o sucesso individual em detrimento do outro, subordinando, de modo egoísta e estratégica, "o pensamento e a atividade racional a fins e interesses particulares" ${ }^{, 19}$.

16 ABREU, Jayme. Atualidade de John Dewey. In BRABUCHER, John S. Importância da teoria em educação. Trad. Beatriz Osório. Série VII - Cursos e conferências Vol. 3. Rio de Janeiro: Instituto Nacional de Estudos Pedagógicos - INEP/MEC, 1961, p. 11 e 12. Jayme de Abreu integrou o grupo de estudiosos da educação no Instituto Nacional de Estudos Pedagógicos - INEP, atuando, junto com Anísio Teixeira, na difusão da filosofia deweyana no Brasil (ABREU, Jayme. A Educação Secundária no Brasil. Ensaio de identificação de suas características principais. Revista Brasileira de Estudos Pedagógicos, Brasília, v. 86, n. 212, jan./abr. 2005).

${ }^{17}$ SCHEFFLER, Israel. A linguagem da educação. Trad. Balthazar Barbosa Filho. São Paulo: Edusp/Saraiva, 1974 , p. 47 e 48.

${ }^{18}$ HICKMAN, Reading Dewey, 1998, p. ix.

19 DEWEY, John. O desenvolvimento do pragmatismo americano. Trad. Renato Rodrigues Kinouchi. Scientiae Studia. São Paulo, v. 5, n⿳⺈ 2, junho/2007, p. 229, 230, 241 e 242. Disponível em: http://www.scielo.br/scielo.php?script=sci_arttext\&pid=S1678-31662007000200006\&lng=en\&nrm=iso. Acesso em 06/06/2014. 
Tudo isso, portanto, perdendo de vista que a tradição norte-americana do pragmatismo não faz dele uma filosofia presa, de modo inexorável, aos vícios daquela cultura $^{20}$ : "Os pragmatistas não foram apologistas do status quo. Eles estavam entre os mais implacáveis críticos da sociedade americana por não efetivar sua promessa democrática"21. Enfim, como destaca o próprio Dewey:

Ao considerar um sistema filosófico em suas relações com fatores nacionais, é necessário manter em mente não somente aqueles aspectos da vida que estão incorporados no sistema, mas também os aspectos contra os quais o sistema protesta. Nunca houve um filósofo que tenha merecido tal título simplesmente pela razão de haver glorificado as tendências e características de seu ambiente social; assim como nunca houve um filósofo que não tenha sido influenciado por certos aspectos da vida de seu tempo, idealizando-os ${ }^{22}$.

$\mathrm{Na}$ esteira das leituras desatentas e distorcidas e, agora, no âmbito da reflexão pedagógica progressiva, ou nova, do autor, foi adjetivada de proposta burguesa e elitista ${ }^{23}$, no contexto da disputa ideológica que marcou a Guerra Fria e na demarcação dos espaços entre a "pedagogia burguesa de inspiração liberal e o âmbito da pedagogia socialista de inspiração marxista" 24 .

Criticando o descaminho fático de escolas novas no Brasil, Dermeval Saviani ressalta dado importante - mas que, absolutamente, não esgota o valor e as possibilidades dessa experiência educacional - de que, organizando-se basicamente em torno de "escolas experimentais ou como núcleos raros, muito bem equipados e circunscritos a pequenos grupos de elite", aprimoraram, tão somente, a "qualidade do ensino destinado às elites". Com isso, o real destinatário e beneficiário da "democracia" do movimento: "Não foi o povo, não foram os operários, não foi o proletariado. Essas experiências ficaram restritas a pequenos grupos, e nesse sentido elas se constituíram, em geral, em privilégios para os já privilegiados",25.

No final das contas, dentre as críticas oriundas do pensamento socialista, em suas diferentes vertentes, irrogaram a Dewey, os mais exaltados, a pecha de "filósofo da

\footnotetext{
${ }^{20}$ DEWEY, O desenvolvimento do pragmatismo americano, 2007, p. 229 e 230.

${ }^{21}$ BERNSTEIN, The resurgence of pragmatism, 1992, p. 815.

${ }^{22}$ DEWEY, O desenvolvimento do pragmatismo americano, 2007, p. 230.

${ }^{23}$ GADOTTI, História das ideias pedagógicas, 2002, p. 144.

${ }^{24}$ SAVIANI, Escola e democracia, 2008, p. xxxix.

${ }^{25}$ SAVIANI, Escola e democracia, 2008, p. 08, 09 e 39.
} 
burguesia imperialista", "a serviço do grande patronato"26. Pelo menos, um educador que, buscando "a convivência democrática sem, porém, por em questão a sociedade de classes", não passaria, na alcunha dada por Luiz Antônio Cunha, citado por Moacir Gadotti, de um elitista ingênuo ${ }^{27}$.

Mas, pior, a censura a Dewey não se restringiu ao ponto de vista da esquerda. No lado oposto, à direita, ainda no final dos anos 1950, o autor foi alvo, também, de críticas conservadoras dentro da própria sociedade norte-americana. Confundida sua filosofia educacional, sem razão, com o não-diretivismo, foi acusado de frouxidão, de complacência excessiva e de ausência de disciplina ${ }^{28}$.

Nesse sentido, foi "responsabilizado" pelas deficiências do sistema educacional dos Estados Unidos, considerado em crise diante de alegada inaptidão, na disputa com o mundo soviético - o socialismo real -, à formação de pessoal necessário ao atendimento das demandas do progresso científico e tecnológico ${ }^{29}$. A escola progressiva estaria fazendo o país "progredir" mas na direção "da deseducação, do embaraço à educação, do dano ao ser humano em desenvolvimento, do grave risco à estabilidade cultural",30.

Assim, o nome de Dewey, conforme H. Benjamin se referiu com ironia, passou a evocar a "sinistra figura de um professor de filosofia que é de algum modo responsável pelo fato 'de não ser o neto de meu irmão capaz de ler tão bem quanto eu o fazia na sua idade ${ }^{,, 31}$.

Por tudo isso, não se pode afirmar um impacto prático relevante e duradouro de suas concepções e propostas filosóficas pragmatistas e progressivas. Nem mesmo no sistema educacional norte-americano, onde "os métodos por ele descritos não foram amplamente adotados tampouco estabeleceram mudanças fundamentais nas escolas". Fundamentando-se em pesquisa sobre o desenvolvimento da organização escolar dos

${ }^{26}$ MENDONÇA e outros, Pragmatismo e desenvolvimentismo no pensamento educacional brasileiro dos anos de 1950/1960, 2006, p. 99 e 100.

${ }^{27}$ GADOTTI, História das ideias pedagógicas, 2002, p. 143; GADOTTI, Moacir. Pensamento pedagógico brasileiro. São Paulo: Ática, 1991, p. 81.

${ }^{28}$ BRUBACHER, John S. Importância da teoria em educação. Trad. Beatriz Osório. Série VII - Cursos e conferências Vol. 3. Rio de Janeiro: Instituto Nacional de Estudos Pedagógicos - INEP/MEC, 1961, p. 61 e 62.

${ }^{29}$ MENDONÇA e outros, Pragmatismo e desenvolvimentismo no pensamento educacional brasileiro dos anos de 1950/1960, 2006, p. 99, 100 e 103; GHIRALDELLI JUNIOR, Filosofia e história da educação brasileira, 2003, p. 157 e 158.

${ }^{30}$ BELL, Bernard Iddings. Crisis in education: a challenge to American complacency. New York: Whittlesey House, 1949, p. 29.

${ }^{31}$ BENJAMIN, A educação e o ideal democrático, 1960, p. 31 e 32. 
Estados Unidos, desde 1880, Leonard Waks ressalta que as estruturas permaneceram ““extraordinariamente estáveis' e 'extraordinariamente duradouras', não obstante notáveis mudanças na taxa de participação escolar, nas filosofias educacionais e nas políticas educacionais dos governos" ${ }^{\prime 2}$.

Enfim, em sua essência, o programa deweyano jamais se enraizou na educação de seu país ${ }^{33}$. A recepção ao seu pensamento, destaca Anísio Teixeira, não superou "aspectos superficiais e secundários". Ele não foi absorvido, absolutamente, "na sua mais fecunda parte original, no seu esforço de conciliação das contradições e conflitos da vida moderna". Dewey foi um simples precursor, não havendo maior erro "do que supô-lo seguido e, ainda menos, dominante no sistema escolar norte-americano"34.

Como resultado dessa trajetória histórica, a referência à filosofia social e educacional deweyana não pode ser isolada da desatenção, distorções e mal-entendidos que acompanharam sua apreensão. Reforçam a importância, seja para defendê-la, seja para a ela se opor, da "leitura e o estudo cuidadoso do que Dewey realmente disse" 35 .

Essa revisita consistente e crítica ao amplo âmbito da teoria social deweyana tem, também, seu lugar. Isso não pode ser negado. Sobreviveu, ainda que pontualmente, mesmo no cenário norte-americano da segunda metade do Século $\mathrm{XX}^{36}$, e ganha força com o "ressurgimento" do pragmatismo ou terceira fase do movimento, a partir dos anos 1990, na revisita aos autores e temas pragmatistas "clássicos"37. Hans Joas destaca, nesse cenário, o caráter extremamente atual do pragmatismo, atestado diante do fato de que:

(..) grande parte dos principais representantes da filosofia norteamericana contemporânea situam-se expressamente ou são situados na tradição do pragmatismo. A lista de nomes como Richard Rorty, Richard Bernstein, Stephen Toulmin, Thomas Kuhn, Willard Van Orman Quine,

${ }^{32}$ WALKS, Leonard J. John Dewey and the challenge of progressive education. International journal of progressive education. Vol. 09, nํ 01, 2013, p. 77 e 78.

${ }^{33}$ WALKS, John Dewey and the challenge of progressive education, 2013, p. 77 e 78.

34 TEIXEIRA, Anísio. Filosofia e educação. Revista Brasileira de Estudos Pedagógicos. Rio de Janeiro, v.32, n.75, jul./set. 1959. Disponível em http://www.bvanisioteixeira.ufba.br/artigos/filosofia.html. Acesso em 07/01/2013.

35 BRUBACHER, Importância da teoria em educação, 1961, p. 82.

${ }^{36}$ Destaca-se, nesse sentido, em 1966, a publicação, por Bernstein, da obra John Dewey, resultado de seus estudos sobre o filósofo. Ainda no final daquela década, Ann Boydston iniciou reedição da obra de Dewey, "muito dela dispersa e esgotada poucos anos depois de sua morte" (HICKMAN, Reading Dewey, 1998, p. xii).

37 BERNSTEIN, The resurgence of pragmatism, 1992, p. 833 e 834; GHIRALDELLI JUNIOR, Pragmatismo e neopragmatismo, 1999, p. 08. 
Donald Davidson, Hilary Putnam e Nelson Goldman mostram, em seu melhor, o nível em que o pragmatismo permanece um meio de discurso nas universidades americanas, apesar de lá ter sido severamente restringido por décadas ${ }^{38}$.

E isso não se limita à tradição norte-americana, em que vale a referência, por fim, no âmbito da psicologia, a Lawrence Kohlberg, cujos estudos sobre o desenvolvimento moral remontam à concepção deweyana de crescimento e aos níveis de conduta que o integram $^{39}$. A influência do pragmatismo "ressurgindo" e, dentro dela, da filosofia de Dewey, espraiam-se sobre outras tradições filosóficas. Absorvida por representantes da Escola de Frankfurt, como Habermas e Axel Honneth ${ }^{40}$, mitiga a história de incompreensão entre a filosofia alemã e o pragmatismo norte-americano, de que fala o também alemão Joas ${ }^{41}$, ademais de estreitar vínculos no que tange ao tema da democracia.

Nessa linha, tomados os devidos cuidados em sua revisita, atentando-se a esse cenário histórico que a envolve, a filosofia social de John Dewey se distingue, hoje, como referencial extremamente original e fecundo para a reflexão a respeito da educação $n a$ e para a democracia, sob a perspectiva crítica revisora da modernidade ${ }^{42}$.

O autor parte de preciso diagnóstico de modernidade em que contrapõe ao reconhecimento do progresso material, científico e tecnológico, experimentado pela humanidade, na modernidade, sua incapacidade de lidar, inteligentemente, com as questões sociais e morais que a afligem. Em consequência disso, "o homem tem sofrido o impacto do controle enormemente ampliado das energias físicas, sem nenhuma correspondente habilidade para controlar a si mesmo e suas questões próprias" ${ }^{, 43}$.

Diante disso, traz, ao centro da atenção de sua filosofia reconstruída, os conflitos morais e sociais experimentados cotidianamente. Propõe sua solução racional, inteligente,

38 JOAS, Pragmatism and social theory, 1992, p. 01 e 02.

${ }^{39}$ KOHLBERG, Lawrence. La Democracia en la escuela secundaria: educando para una sociedad mas justa. Trad. Maria Mercedes Oraison. Chaco: Universidad Nacional del Nordeste, 1992, p. 03 e 04; DEWEY, John. Ethics. The Later Works 1925-1953. Volume 07 (1932). Edited by Jo Ann Boydston. Southern Illinois University, 2008, p. 12 e 13.

${ }^{40}$ BERNSTEIN, The resurgence of pragmatism, 1992, p. 835; HONNETH, Axel. Democracy as reflexive cooperation: John Dewey and the theory of democracy today. Political Theory, vol. 26, nº 06, Dez/1998.

${ }^{41}$ JOAS, Pragmatism and social theory, 1992, p. 116.

42 BERNSTEIN, The resurgence of pragmatism, 1992, p. 839 e 840; JOAS, Pragmatism and social theory, 1992 , p. 116.

${ }^{43}$ DEWEY, John. Psychology and Social Practice. Contributions to education $\mathrm{n}^{\mathrm{o}}$ II. Chicago: University of Chicago Press, 1901, p. 40; DEWEY, John. The public and its problems. Swallow Press/Ohio University Press/Athens, 1991, p. 175; DEWEY, John. Reconstruction in philosophy. Mineola/New York: Dover Publications, 2004, p. 44. 
por meio do pensar reflexivo, orientado à práxis, e, para tanto, a incorporação, pela filosofia, dos benefícios proporcionados pela ciência moderna, compreendida em sua qualidade de um hábito da mente, uma atitude investigativa, metódica, experimental e falibilista $^{44}$.

Tudo isso, para o autor, no âmbito das experiências comunicativas que definem a educação e a democracia: experiências indissociáveis, uma pressupondo e enriquecendo a outra, na direção da emancipação humana ${ }^{45}$.

Nesse sentido, atenta em se afastar de um pensar "por meio de opostos extremos"46, a filosofia social deweyana não significa o rompimento com o projeto moderno. Dewey é, sem dúvida, um filósofo moderno. Porém, é também crítico da modernidade, sem cair em antimodernismos.

Tendo em vista a compreensão profunda da educação e da democracia na filosofia social de Dewey, o presente capítulo, partindo do diagnóstico de modernidade apresentado pelo autor, analisa, primeiro, as linhas principais por onde caminha sua proposta pragmatista de reconstrução filosófica, apreendendo-a na perspectiva citada de uma crítica que não perde, por isso, seus traços profundamente modernos.

Na sequência, debruça-se sobre três construções teóricas do autor, centrais na fundamentação e moldagem de sua filosofia social. Primeiro, a teoria da experiência, entendida, em linhas gerais, como a interação contínua entre o sujeito e o que, num dado momento, constitui seu ambiente; entre o fazer e o sofrer as consequências do próprio comportamento $^{47}$. Segundo, sua formulação sobre o pensar reflexivo, racional: um processo de "busca do ausente a partir do presente", provocado, necessariamente, por um

${ }^{44}$ DEWEY, Reconstruction in philosophy, 2004, p. iii, v e 16; DEWEY, John, Freedom and culture. Nova York: Prometheus Books, 1989, p. 111; CUNHA, Marcus Vinicius da. Comunicação e arte, ou a arte da comunicação, em John Dewey. Revista Brasileira de Estudos Pedagógicos, Brasília, v. 86, nº 213/214, maio/dez. 2005, p. 12.

${ }^{45}$ BERNSTEIN, The resurgence of pragmatism, 1992, p. 815; JOAS, Pragmatism and social theory, 1992, p. 17.

${ }^{46}$ DEWEY, John. Experiência e educação. Trad. Renata Gaspar. Petrópolis/RJ: Vozes, 2010, p. 19.

${ }^{47}$ DEWEY, Reconstruction in philosophy, 2004, p. 49; TEIXEIRA, Anísio. A pedagogia de Dewey (Esboço da teoria de educação de John Dewey). In DEWEY, John, Experiência e natureza; Lógica: a teoria da investigação; A arte como experiência; Vida e educação; Teoria da vida moral. Trad. Murilo O. Rodrigues Paes Leme, Anísio S. Teixeira e Leônidas Gontijo de Carvalho. Coleção Os Pensadores. São Paulo: Abril Cultural, 1980, p. 113. 
problema enfrentado no curso da ação, da experiência ${ }^{48}$. Essas teorias conduzem a uma terceira concepção, fundamental em Dewey, acerca da constituição social e do crescimento cognitivo e moral do indivíduo, em direção à autonomia, no processo reflexivo e comunicativo, contínuo e reconstrutivo, da experiência.

A partir disso, pode ser debatido, de modo consistente, o modelo de democracia propugnado por Dewey e por ele descrito como um ideal social e moral que, muito mais do que uma forma de governo, remete ao momento anterior à vida política propriamente dita, qual seja, a vida comunitária. Consolida-se, em síntese, como uma experiência social comunicativa de solução compartilhada e cooperativa de problemas de coordenação social, assim identificados pelos membros da sociedade, reunidos num público, com o amparo de uma estrutura político-governamental ${ }^{49}$.

Finalmente, o capítulo trata de sua concepção progressiva de educação, a florescer a partir da comunidade democrática e a promovê-la, dialeticamente. É compreendida como o processo contínuo de crescimento cognitivo e moral do sujeito, habilitando-o a "continuar sua educação", autonomamente, ou, dito de outra forma, conferindo-lhe a "capacidade de crescimento continuado". E isso por meio do desenvolvimento, em interação dialógica, do hábito reflexivo do pensar, agir e conviver, na solução de problemas e lacunas na experiência, de modo a, progressivamente, ampliar e adensar seu significado, habilitando a pessoa à direção, inteligente e compartilhada, do curso das experiências ulteriores, individuais e coletivas ${ }^{50}$.

\section{A modernidade e a crítica na filosofia social de John Dewey}

O pensamento social de John Dewey descortina-se a partir de diagnóstico da modernidade. Diante dele, alinhado com as preocupações e temas centrais da tradição do pragmatismo, em seu momento inicial, apresenta e justifica um programa de reconstrução do objeto e da atuação da filosofia.

${ }^{48}$ DEWEY, John. How we think. Mineola, New York: Dover Publications, 1997, p. 09 e 26.

${ }^{49}$ DEWEY, The public and its problems, 1991, p. 33, 83, 148 e 149; HONNETH, Democracy as reflexive cooperation, 1998, p. 775.

${ }^{50}$ DEWEY, John. Democracy and education. An introduction to the philosophy of education. New York: The Macmillan Company, 1916, p. 63, 89, 90 e 117; DEWEY, Reconstruction in philosophy, 2004, p. 106; DEWEY, Experiência e educação, 2010, p. 36. 
1.1. O autor identifica, na modernidade, a interdependência entre a revolução científica e a revolução industrial, estabelecendo uma "ininterrupta e penetrante interação entre a descoberta científica e a aplicação industrial": "a indústria moderna é, em grande medida, ciência aplicada". E isso de modo tal que restaram ligados de maneira inextricável ciência natural, experimentação, controle e progresso ${ }^{51}$.

A aplicação especializada da razão moderna promoveu inegável e estrondoso progresso científico e tecnológico. Mas promoveu, ao mesmo tempo, um novo padrão de interação social, caracterizado pela "produção em massa para mercados distantes, pelo cabo e telefone, pela impressão a baixo custo, pela estrada de ferro e pela navegação a vapor", que, se possibilitou a aproximação entre povos e culturas, veio marcado, também, pelo aumento da complexidade, pela instabilidade e pela desintegração das relações humanas. A guerra aparece como "manifestação normal do subjacente estado de desintegração da sociedade" ${ }^{, 52}$.

Pega a humanidade numa "varredura de forças muito vastas para entender e dominar", os progressos experimentados influenciam, basicamente, os meios de vida social e não seus fins. E estes acabam definidos de modo muito mais casual, circunstancial, pervertendo-se, de qualquer forma, em "fins pecuniários em proveito de poucos", "objetivos que visam poder e vantagens pessoais"

As conquistas técnicas e econômicas, o enorme desenvolvimento científico no campo da engenharia, química, física, etc., os inegáveis avanços tecnológicos no controle e transformação do mundo físico não foram acompanhados, na mesma medida, de progresso moral, de avanços no que se refere à reflexão e ao julgamento racional, crítico e sistemático do valor da conduta humana, na experiência social - o objeto, para Dewey, de uma teoria moral. Implicam, pelo contrário, novas perturbações sociais e morais, que o homem é incapaz de resolver, num contexto em que a regulação e a reconstrução das experiências "tem sido técnica ao invés de humana e moral, econômica ao invés de adequadamente social" ${ }^{, 54}$.

${ }^{51}$ DEWEY, Reconstruction in philosophy, 2004, p. 24 e 25.

52 DEWEY, The public and its problems, 1991, p. 126, 127, 131 e 141.

${ }^{53}$ DEWEY, The public and its problems, 1991, p. 135 e 174; DEWEY, 2004, Reconstruction in philosophy, p. 25; DEWEY, Experiência e educação, 2010, p. 84.

${ }_{54}$ DEWEY, Reconstruction in philosophy, 2004, p. 25 e 55; DEWEY, The public and its problems, 1991, p. 175; DEWEY, Ethics, 2008, p. 09; DEWEY, John. The study of ethics. A syllabus. Ann Arbor: The Inland Press, 1879, p. 01. 
Nos descaminhos da modernidade, o conhecimento se dividiu contra si mesmo, moral versus razão, natureza versus cultura, ciência versus filosofia, ciência versus ciência, de modo que à sua incompletude, somou-se a cisão. Com isso, sem a definição inteligente, racional do valor e dos objetivos das experiências sociais, o "homem, uma criança na compreensão de si, tomou em suas mãos ferramentas de poder incalculável”, permitindo que a instrumentalidade se torne senhor, trabalhando "como se possuísse vontade própria não porque a tenha, mas porque os homens não têm",55.

Possibilita, assim, que, na sua prática especializada, a razão científica, desatenta ao enfrentamento dos problemas propriamente humanos - deformada, assim, em cientificismo - seja protagonista, dentre outros barbáries, da exploração brutal e inconsequente da natureza, da produção de armas químicas e de destruição de massa; "da escravidão de homens, mulheres e crianças nas fábricas, nas quais são máquinas animadas para cuidar de máquinas inanimadas"; da perpetuação da oposição entre a pobreza extrema, de um lado, e a riqueza voluptuosa, de outra ${ }^{56}$.

Tal deformação, que enfatiza "as deficiências sociais maiores que demandam diagnóstico inteligente e o planejamento de objetivos e métodos", define, para Dewey, o problema da reconstrução da filosofia ${ }^{57}$.

1.2. Para seu enfrentamento, destaca-se, em primeiro lugar, na proposta de reconstrução filosófica, o rompimento com a metafísica, da qual, no entender de Dewey - de modo notavelmente similar à crítica pós-moderna, como proposta por Jean-François Lyotard ${ }^{58}$, sessenta anos depois -, a modernidade ainda não conseguiu se desvencilhar.

A reconstrução se coloca a partir da rejeição ao dualismo platônico, no âmbito do qual a filosofia virou as costas ao mundo da experiência e se voltou ao conhecimento e justificação racional de outra realidade, última, à qual toda experiência estaria subordinada e conformada. Esta realidade metafísica, porém, explica Dewey, não passa de um asilo em

\footnotetext{
${ }^{55}$ DEWEY, The public and its problems, 1991, p. 175.

${ }^{56}$ DEWEY, The public and its problems, 1991, p. 175.

${ }^{57}$ DEWEY, Reconstruction in philosophy, 2004, p. 25.

${ }^{58}$ LYOTARD, Jean-François. The postmodern condition: a report on knowledge. Trad. Geoff Bennington e Brian Massumi. Minneapolis: University of Minnesota Press, 1984, p. xxiv.
} 
que fora filosoficamente alocado e protegido, como superior, absoluto e universal, um (e não outros possíveis) corpo de crenças, valores e hábitos herdados do passado ${ }^{59}$.

Dessa forma, a filosofia deweyana recusa qualquer determinismo histórico assim como de qualquer fundamento seguro em que se possa apoiar, a priori e metafisicamente, o conhecimento, a razão e as esperanças de um futuro feliz.

Não há mais que se falar em pretensos universais, aprioristicamente dados e acessíveis à razão "como faculdade separada da experiência"60. Não há $o$ Estado, $o$ indivíduo, $a$ razão, $o$ bem, $a$ moral, $o$ justo, $a$ verdade, $a$ revolução, $a$ utopia, que possam determinar e limitar as possibilidades experienciais, constituindo o mundo objetivo e social de modo rigidamente fechado e predefinido. O desenvolvimento, o progresso não está subordinado a causas finais aristotélicas, dentro das quais não significa nada mais que o curso monótono e invencível da atualização das potências de um indivíduo, dentro de uma espécie, "apenas um nome para o predeterminado movimento da bolota para a árvore de carvalho" 61 .

O universo, em que se efetivam as experiências humanas, é compreendido de forma aberta, um "universo cuja evolução não está acabada (..) que ainda está, nas palavras de James, "se fazendo", 62 , e que, em seu processo de tornar-se, vem marcado por uma invencível contingência ${ }^{63}$. Afinal, compõe-se de um "conjunto infinito de elementos que se relacionam de maneira a mais diversa possível. A multiplicidade e a variedade dessas relações o fazem essencialmente precário, instável, e o obriga a perpétua transformação" "64.

1.3. Nesse cenário, em que os homens não são - pelo menos, não precisam ser - objetos passivos, determinados por forças além de seu controle e, por conseguinte, em que podem, ainda que de forma limitada e contextualizada, influenciar e inovar o curso de suas futuras experiências, Dewey defende que isso seja feito de modo inteligente, racional, criativo e em proveito de todo o grupo social em que se está inserido ${ }^{65}$.

\footnotetext{
${ }^{59}$ DEWEY, Reconstruction in philosophy, 2004, p. 10 a 12.

${ }^{60}$ DEWEY, Reconstruction in philosophy, 2004, p. 55.

${ }^{61}$ DEWEY, Reconstruction in philosophy, 2004, p. 32, 33, 34 e 104.

${ }^{62}$ DEWEY, O desenvolvimento do pragmatismo americano, 2007, p. 236.

${ }^{63}$ BERNSTEIN, The resurgence of pragmatism, 1992, p. 814.

${ }^{64}$ TEIXEIRA, A pedagogia de Dewey, 1980, p. 113.

${ }^{65}$ BERNSTEIN, The resurgence of pragmatism, 1992, p. 815; DEWEY, O desenvolvimento do pragmatismo americano, 2007, p. 236.
} 
Para tanto, a filosofia reconstruída se volta e enraíza-se na experiência. Como proposta pragmatista e, portanto, como "filosofia da ação",66, concebe o pensar necessariamente referido e comprometido com a práxis.

O pragmatismo, esclarece William James, deriva da palavra grega prágma, que significa $a c ̧ \tilde{a} o$, tendo sido introduzido, em filosofia, por Charles Peirce, que "após salientar que nossas crenças são, realmente, regras de ação, dizia que, para desenvolver o significado de um pensamento, necessitamos apenas determinar que conduta está apto a produzir: aquilo é para nós o seu único significado". Eis, afinal, “o princípio do pragmatismo" pensar-se como produzidos pelo objeto de nossa concepção. A concepção destes efeitos é a concepção total do objeto"68.

Para descobrir o sentido de uma ideia, em termos pragmatistas, resume Dewey, "pergunte por suas consequências". É a aplicação do conceito que "se torna o critério de seu valor; e aqui se encontra todo o pragmatismo em seu estágio embrionário"69.

Nessa linha, na acepção deweyana, o conteúdo da filosofia e do pensamento em geral emerge das experiências de vida e dos variáveis e incertos problemas e questões que delas brotam. E só adquire sentido quando aplicados para sua solução. Sua reconstrução, rechaçando, de modo pragmatista, qualquer separação forjada entre a teoria e a prática, insiste na referência do pensar à experiência, à interação humana, em que se fundamenta e na qual é aplicada ${ }^{70}$.

A tarefa da inteligência não é a de copiar os objetos do ambiente, numa perspectiva passiva, de um "espectador visualizando um quadro acabado em vez daquele do artista produzindo a pintura”. Não se justifica que a filosofia se restrinja a habitar a região de seus próprios conceitos, em que “'resolve' problemas, demonstrando a relação de ideias, ao

${ }^{66}$ JOAS, Pragmatism and social theory, 1992, p. 18.

67 JAMES, William. Pragmatismo. Textos selecionados. Trad. Pablo Rubén Mariconda. Coleção Os pensadores XL. São Paulo: Abril Cultural, 1974, p. 10.

${ }_{68}$ PEIRCE, Charles S. Escritos coligidos. Seleção de Armando Mora D'Oliveira. Trad. Armando Mora D’Oliveira e Sérgio Pomerangblum. Coleção Os pensadores. 2a ed. São Paulo: Abril Cultural, 1980, p. 05.

${ }^{69}$ DEWEY, Reconstruction in philosophy, 2004, p. 94; DEWEY, $O$ desenvolvimento do pragmatismo americano, 2007, p. 239.

${ }^{70}$ DEWEY, Reconstruction in philosophy, 2004, p. iii; DEWEY, The public and its problems, 1991, p. 174; DEWEY, O desenvolvimento do pragmatismo americano, 2007, p. 227 a 229; CUNHA, Marcus Vinicius de. John Dewey: filósofo, educador e ativista social. In DEWEY, John. Democracia e educação: capítulos essenciais Apresentação e comentários de Marcus Vinicius da Cunha. Trad. Roberto Cavallari Filho. São Paulo: Ática, 2007, p. 134. 
invés de auxiliar o homem a resolver problemas concretos, fornecendo-lhe hipóteses a serem usadas e testadas em projetos de reforma"71.

A proposta deweyana, nesse sentido, é a de uma filosofia reconstrutiva, criativa, atenta às situações concretas e específicas vividas pelo homem em seu cotidiano e, desse modo, voltada à identificação e à solução dos conflitos morais e sociais que delas emergem $^{72}$.

Induz, sim, uma instrumentalidade da filosofia, na medida em que reconhece a inteligência, a racionalidade, como instrumento para a organização e reconstrução das experiências, auxiliando "a fazer o mundo de maneira diversa do que teria sido sem a razão" e, portanto, fazendo "com que o mundo seja realmente mais razoável", no sentido de mais adequado aos objetivos que propusemos a nós mesmos ${ }^{73}$.

E isso, portanto, como já indicado, num significado que nada tem a ver com a adulteração da razão utilizada como instrumento para os objetivos de poder e lucro de poucos. O caráter instrumental da razão remete à tarefa reconstrutiva, no sentido de descortinar possibilidades de experiências melhores e mais proveitosas no futuro, especialmente experiências humanas coletivas. Possibilita o enfrentamento dos graves problemas sociais e morais sofridos pela humanidade, promovendo, dessa forma, o crescimento geral e contínuo e o permanente enriquecimento e melhoria da qualidade das experiências $^{74}$.

1.4. Para tanto, Dewey aposta na adoção, pela filosofia, da atitude, do espírito que acompanhou o desenvolvimento das ciências da natureza na modernidade, mas que, ressalta, ainda não alcançou o âmbito das questões propriamente humanas $^{75}$.

A filosofia reconstruída "não se sente em oposição à ciência”. É, antes, "um agente de ligação entre as conclusões da ciência e os modos de ação social e pessoal através dos quais se projetam e se buscam possibilidades alcançáveis" ${ }^{76}$.

${ }^{71}$ DEWEY, Reconstruction in philosophy, 2004, p. 71 e 110; DEWEY, O desenvolvimento do pragmatismo americano, 2007, p. 239.

${ }^{72}$ DEWEY, Reconstruction in philosophy, 2004, p. 16, 70 e 100.

${ }^{73}$ DEWEY, O desenvolvimento do pragmatismo americano, 2007, p. 236 e 240.

${ }^{74}$ DEWEY, Reconstruction in philosophy, 2004, p. 16, 54, 70, 71 e 100; DEWEY, O desenvolvimento do pragmatismo americano, 2007, p. 239; DEWEY, Experiência e educação, 2010, p. 37.

${ }^{75}$ BERNSTEIN, The resurgence of pragmatism, 1992, p. 814; DEWEY, Reconstruction in philosophy, 2004, p. v, 25, 30, 31, 43 e 44 . 
Mas o que o autor valoriza na ciência moderna não é a perspectiva dogmática de um "corpo de conclusões", o apego e aplicação restrita das "verdades científicas". Aliás, como ressalta, a disseminação das qualidades da ciência é uma questão distinta da "disseminação dos resultados da física, química, biologia e astronomia"77.

O fator científico integrado à reconstrução filosófica deweyana é, precipuamente, a qualidade da ciência moderna de uma disposição, um hábito, uma atitude investigativa, metódica, experimental e falibilista ${ }^{78}$.

Nesse sentido, remete à aplicação, às questões e aos temas sociais e morais vivenciados pelo homem em seu cotidiano, dos métodos científicos de pesquisa, reflexão e experimentação. Remete à assunção das crenças e ideias como provisórias - nunca como dogmas - e, dessa forma, como hipóteses a serem empregadas na solução de problemas e na reorganização da experiência, somente aceitas após a verificação experimental de sua validade, e, ainda assim, passíveis sempre de serem revisadas e refutadas por novas investigações. Envolve, por conseguinte, a habilidade de "manter o estado de dúvida e continuar a investigação sistemática e prolongada", a propensão à busca permanente por conhecimento, a abertura à descoberta do novo, a novos campos de pesquisa $\mathrm{e}$ experimentação. Enfim, um hábito da mente, como afirma Dewey que se aproxima muito daquela "atitude natural e intata da infância, marcada pela curiosidade ardente, imaginação fértil e amor à investigação experimental"79.

Nessa perspectiva atitudinal da ciência, a razão, trazida para dentro da experiência e empregada em sua expansão e reconstrução, atua como inteligência experimental:

Ela libera o homem da escravidão do passado, devida à ignorância e ao acaso que se arraigaram nos costumes. Ela projeta um futuro melhor e assiste o homem na sua realização. E sua operação está sempre sujeita ao teste da experiência. Os planos que são formados, os princípios que o homem projeta como guias de ações reconstrutivas, não são dogmas. Eles são hipóteses a serem executadas na prática e para serem rejeitadas, corrigidas e expandidas conforme falhem ou tenham sucesso em dar à nossa experiência presente a orientação necessária ${ }^{80}$.

${ }^{76}$ DEWEY, John. The quest for certainty: a study of relation of knowledge and action. New York: Minton, Balch \& Company, 1929, p. 311.

${ }_{77}^{77}$ DEWEY, Freedom and culture, 1989, p. 111 e 117.

${ }^{78}$ DEWEY, Freedom and culture, 1989, p.111; BERNSTEIN, The resurgence of pragmatism, 1992, p. 814; TEIXEIRA, Filosofia e educação, 1959.

${ }^{79}$ DEWEY, Freedom and culture, 1989, p.111 e 112; DEWEY, Reconstruction in philosophy, 2004. p. v, 83, 89 e 90; DEWEY, How we think, 1997, p. vii e 13.

${ }^{80}$ DEWEY, Reconstruction in philosophy, 2004, p. 55. 
A questão da verdade, nesse cenário pragmatista, está indissociavelmente ligada à experiência, à prática. É adverbial, no sentido de que indica um modo de agir. Significa a sugestão de resposta ao problema na experiência que, testada, colocada em ação, recebe a confirmação de sua validade, de sua fiabilidade, esclarecendo a confusão, removendo a dificuldade, preenchendo as lacunas da experiência e, por tudo isso, guiando-nos verdadeiramente em nossos processos experienciais de interação com o ambiente ${ }^{81}$.

Contudo, sem bases metafísicas seguras em que possa se apoiar de uma vez por todas, o conhecimento verdadeiro, ainda que assim afirmado cientificamente, não perde, nunca, seu caráter provisório. É uma pretensão. Está sempre sujeito a correções em função de aspectos, relações e possibilidades experienciais não considerados. A verdade absoluta, nesses termos, é uma pretensão que não pode se realizar, exceto se se imaginar que todo o conjunto infinito de elementos que compõem o universo, em suas incontáveis perspectivas, e suas inesgotáveis possibilidades de se relacionar e de se desenvolver possam, um dia, ser conhecidos e experimentados. E, desse modo, esgotado o infinito, não haja mais nada que não tenha sido observado e "catalogado", nenhuma experiência que já não tenha sido efetivada $^{82}$.

De qualquer forma, a atitude científica tem a vantagem da menor sujeição ao erro e à desrazão, emancipando o pensar do preconceito, da tirania dos hábitos, da rotina, do acaso e dos impulsos. Reconhecido o lugar da inteligência na compreensão, no controle e no desenvolvimento de possibilidades inerentes à experiência, tal atitude aparece como a forma mais apropriada, à nossa disposição, para o entendimento profundo do mundo em que vivemos. Convertida na filosofia reconstruída, revela-se o modo apropriado para o esclarecimento e enfrentamento racional dos conflitos morais e sociais cotidianamente experimentados. Indica "o caminho para medidas e políticas que poderão nos conduzir a uma melhor ordem social" $" 83$.

\footnotetext{
${ }^{81}$ DEWEY, Reconstruction in philosophy, 2004, p. 90.

${ }^{82}$ BERNSTEIN, The resurgence of pragmatism, 1992, p. 814; DEWEY, O desenvolvimento do pragmatismo americano, 2007, p. 235.

${ }^{83}$ DEWEY, How we think, 1997, p. 153 e 155; DEWEY, Reconstruction in philosophy, 2004, p. 43 e 44; DEWEY, Experiência e Educação, 2010, p. 84, 90, 92 e 93.
} 
1.5. Destacada a dimensão social da experiência, é fundamental, ainda, na reconstrução deweyana, a concepção comunicativa da filosofia e, de modo geral, da construção do saber, necessariamente imersa num contexto linguístico.

Primeiro, porque, na linha da psicologia social de George H. Mead, a própria constituição do indivíduo pensante é compreendida como um processo social comunicativo: o ego, explica Mead, emerge a partir da comunicação, por meio da qual participamos do outro e, assumindo a atitude do outro em relação a nós, ingressamos em nossa própria experiência, como um objeto para nós mesmos. Obtemos, assim, a autoconsciência, em interação comunicativa, através do outro ${ }^{84}$.

Nesse sentido, em que se enfatiza "a preexistência temporal e lógica do processo social, em relação à autoconsciência individual que dele surge" ${ }^{, 85}$, Dewey pode afirmar que "o solilóquio é o resultado e o reflexo da conversação com os outros" e não a comunicação social "um efeito do solilóquio":

Se não houvéssemos conversado com outros e eles conosco, jamais falaríamos a nós e conosco. Por causa do conversar, dar e receber sociais, posturas orgânicas várias passam a constituir uma reunião de pessoas ocupadas em conversar, conferenciando umas com as outras, em trocar experiências diversas, em ouvir-se mutuamente, bisbilhotando, acusando e escusando. Através do falar, uma pessoa identifica-se com atos e feitos potenciais; desempenha muitos papeis (...) num drama contemporaneamente representado. Assim emerge a mente ${ }^{86}$.

Nega-se, portanto, a possibilidade de uma razão solitária, inata ao homem, anterior à experiência e capaz, por si só, de atingir a verdade. Para Dewey, a concepção de um indivíduo, em seu isolamento, detentor de uma "faculdade pronta de previdência e cálculo prudente", é uma ficção; o conhecimento, preso na consciência privada, um mito ${ }^{87}$.

Eis um traço marcante do pragmatismo norte-americano: a ruptura com o solipsismo, o subjetivismo excessivo da filosofia da consciência, que marcara a modernidade, ressaltando, em oposição, a dimensão intersubjetiva, social e linguística do

${ }^{84}$ MEAD, George Herbert. Mind, self and society: from the standpoint of a social behaviorist. Edited and with a introduction by Charles W. Morris. Chicago/London: The University of Chicago Press, 1992, p. 138, $171,226,253$ e 254.

${ }^{85}$ MEAD, Mind, self and society, 1992, p. 164 e 186.

${ }^{86}$ DEWEY, John. Experiência e natureza. In DEWEY, John Experiência e natureza; Lógica: a teoria da investigação; A arte como experiência; Vida e educação; Teoria da vida moral. Trad. Murilo Otávio Rodrigues Paes Leme, Anísio S. Teixeira e Leônidas Gontijo de Carvalho. Coleção Os Pensadores. São Paulo: Abril Cultural, 1980, p. 31.

${ }^{87}$ DEWEY, The public and its problems, 1991, p. 102, 103 e 176. 
pensamento e do conhecimento ${ }^{88}$. A faculdade de pensar, as perspectivas a partir das quais os objetos são observados e conhecidos são "hábitos adquiridos sob a influência da cultura e instituições da sociedade, não poderes inatos”. Dependem da tradição, dos valores, dos conhecimentos e das ferramentas disponíveis, socialmente desenvolvidas, sancionadas e transmitidas ${ }^{89}$. Isso aparece, mais tarde, em Habermas, na formulação de que "não há uma razão pura que só posteriormente vestiria roupagens linguísticas. A razão é originariamente uma razão encarnada tanto nos contextos de ações comunicativas como nas estruturas do mundo da vida"90

A interação social comunicativa, enfim, é a experiência viva que nos constitui, dentro de uma determinada comunidade linguística, e nos habilita à reflexão e ao conhecimento, numa dada perspectiva histórico-cultural. Para Dewey, "Tudo o que é distintivamente humano é aprendido, não nativo". O "aprender a ser homem" ocorre na interação social, na comunicação, em que é a pessoa é trazida para dentro das "tradições, perspectivas e interesses que caracterizam a comunidade". Significa "desenvolver, por meio do dar e receber da comunicação, uma efetiva consciência de ser um membro, individualmente distinto, de uma comunidade" ${ }^{91}$.

Mas não é só. A comunicação aparece, também, como o instrumento fundamental para a aquisição, expansão, desenvolvimento, enriquecimento e permanente correção do saber. Apresenta, desse modo, seu inigualável sentido instrumental-cognitivo ${ }^{92}$.

A mente individual é falível, suscetível de erros. Deixado a si mesmo, o indivíduo pode muito pouco, envolvido na teia de enganos por ele tecida. Quando não compartilhadas, as ideias "são apenas solilóquio e solilóquio é apenas pensamento imperfeito e débil" ${ }^{\prime 93}$. Nesse cenário falibilista, sem a referência metafísica para predizer a verdade, todo e qualquer saber reivindica sua permanente abertura à crítica, no ambiente discursivo. Com Peirce, a "comunidade de pesquisadores para testar e criticar todas as pretensões de validade" ${ }^{, 94}$.

\footnotetext{
${ }^{88}$ BERNSTEIN, The resurgence of pragmatism, 1992, p. 814.

${ }^{89}$ DEWEY, 1991, The public and its problems, p. 158.

90 HABERMAS, Jürgen. O discurso filosófico da modernidade. Trad. Luiz Sérgio Repa e Rodnei Nascimento. São Paulo: Martins Fontes, 2002, p. 447.

${ }^{91}$ DEWEY, The public and its problems, 1991, p. 154.

92 DEWEY, Experiência e natureza, 1980, p. 39 e 51; DEWEY, Reconstruction in philosophy, 2004, p. 118.

93 DEWEY, The public and its problems, 1991, p. 218; DEWEY, Reconstruction in philosophy, 2004, p. 21.

${ }^{94}$ BERNSTEIN, The resurgence of pragmatism, 1992, p. 814.
} 
E quanto melhor a qualidade dos participantes, em termos da atitude e disposição científica valorizada por Dewey, quanto mais a comunicação se efetiva como uma experiência cooperativa e compartilhada, e quanto maior o número de participantes envolvidos da comunicação, maiores as chances de uma resposta inteligente, razoável, adequada ao problema colocado ${ }^{95}$.

Enfim, a linguagem que possibilita a formação da individualidade e a consumação da própria comunicação é ela mesma o instrumento do crescimento do indivíduo comunicante, concomitante ao desenvolvimento do conhecimento comunicado.

Duas pessoas somente podem conversar, inteligentemente, porque a experiência linguística comum provê "um pano de fundo de entendimento mútuo sobre o qual as respectivas observações incidem" "96 . É dela que emerge, então, como um problema, o antagonismo de ideias - em Habermas, um “não" à pretensão de validade contida na oferta de fala ${ }^{97}$. E isso permite a revisita, a correção do saber partilhado:

Se, todavia, as duas pessoas se encontram com propósitos contrários, é necessário escavar e comparar as pressuposições, o contexto implícito, em conformidade com o qual se fala. O implícito é feito explícito; o que era inconscientemente assumido é exposto sob a luz do dia consciente. Dessa forma, a raiz do mal-entendido é removida ${ }^{98}$.

Criticado, reconsiderado, testado e revisado frente às exigências da conversação, enriquece-se o saber tradicional que compõe o pano de fundo da comunicação e do pensamento, corrigindo suas falhas e apresentando, sempre, novos problemas, sob novas perspectivas. Assim, mais profundo e completo vai se tornando o significado dos objetos que compõem a experiência: significado que, definido por Dewey, como "comunidade de participação", tem, em última análise, sua qualidade diretamente proporcional à qualidade do universo de discurso no qual é comum ${ }^{99}$. Tudo a indicar um processo gradual, expansivo, progressivo, de explicitação, correção e o refinamento do conhecimento ${ }^{100}$.

A experiência comunicativa, sem dúvida, é confrontada por particularismos semânticos, limitações e imperfeições da experiência social em que se desenvolve, perdendo, com frequência seu sentido cooperativo e pervertendo-se em meio de

\footnotetext{
${ }^{95}$ HONNETH, Democracy as reflexive cooperation, 1998, p. 772.

${ }^{96}$ DEWEY, How we think, 1997, p. 214.

${ }^{97}$ HABERMAS, Jürgen. Verdade e justificação. Ensaios filosóficos. Trad. Milton Camargo Mota. $2^{\mathrm{a}}$ ed. São Paulo: Loyola, 2009, p. 92.

${ }_{98}$ DEWEY, How we think, 1997, p. 214 e 215.

${ }^{99}$ DEWEY, Experiência e natureza, 1980, p. 29, 36, 40 e 51.

${ }^{100}$ DEWEY, How we think, 1997, p. 120 e 215.
} 
dominaçã $o^{101}$. Em seu melhor sentido, ademais, constitui uma "nobre arte" ainda ao alcance de poucos. Ainda assim, no cenário, dirá Habermas, pós-metafísico ${ }^{102}$, permanece como a instância racional, e falível, em que o saber e, nele, a filosofia podem se apoiar.

1.6. Desse modo, integrando a atitude científica, constituindo-se intersubjetivamente, na interação comunicativa e, com esses referenciais, voltando sua atenção às questões e conflitos sociais e morais que afligem o homem em sua vida cotidiana, a filosofia reconstruída assume uma concepção de moralidade que pode ser racionalmente conhecida. Faz-se como uma teoria moral cognitivista.

A reflexão moral, em Dewey, remete ao sentido específico de um campo do saber que lida com a conduta humana e o julgamento reflexivo e sistemático de seu valor, na medida em que a estima sob o ponto de vista do certo ou errado, do bom ou mal ${ }^{103}$.

Para o autor, a cisão entre a razão e a moral implica deixar os conflitos de conduta à mercê de soluções não inteligentes, pautadas em critérios tradicionais inquestionados, no interesse, no proveio pessoal, no poder. Pois, "Se o controle da conduta importa no conflito de vontades sem a possibilidade de escolha da vontade e do propósito por meio de crenças garantidas cientificamente, então, a alternativa prática é a competição e o conflito entre forças não inteligentes para o controle da vontade" ${ }^{104}$.

No curso da modernidade, em que a ciência e as tecnologias por meio dela desenvolvidas têm determinado, cada vez mais, as relações sociais, rechaçar a elas e a razão como componentes que podem participar efetivamente da constituição da moral, do julgamento do valor de referidas relações, é condenar a civilização ao regresso. Afinal, "A cultura que permite à ciência destruir os valores tradicionais, mas que desconfia de seu poder para criar novos valores, é uma cultura que está se autodestruindo"105.

Daí a proposta deweyana de transferir o fardo da moralidade à inteligência. E, assim, fazer da filosofia um instrumento que auxilie a construção do saber moral, adotando, para tanto, na reflexão sobre o valor, o bem da conduta e das relações humanas,

\footnotetext{
101 DEWEY, Experiência e natureza, 1980, p. 50 e 51; DEWEY, O desenvolvimento do pragmatismo americano, 2007, p. 236.

${ }^{102}$ HABERMAS, Jürgen. Direito e democracia: entre factibilidade e validade. Volume 02. Trad. Flávio Beno Siebeneichler. Rio de Janeiro: Tempo Brasileiro, 2011, p. 214.

${ }^{103}$ DEWEY, The study of ethics, 1897, p. 01 e 02; DEWEY, Ethics, 2008, p. 09;

${ }^{104}$ DEWEY, Freedom and culture, 1989, p.117.

${ }^{105}$ DEWEY, Freedom and culture, 1989, p.118.
} 
a atitude científica, fundada "na observação e na experiência, na hipótese, na verificação e na revisão constante de suas conclusões"106. Foi ela que, na modernidade, garantiu a segurança, o rigor e a fertilidade do conhecimento no âmbito dos fenômenos físicos ${ }^{107}$.

A filosofia reconstruída se organiza, dessa forma, como um método de investigação, de planejamento e, ainda, de invenção. Ocupa-se, de modo racional, com a detecção dos problemas e males que necessitam de solução, no âmbito das experiências sociais concretas, cotidianas, e com a formação de hipóteses de trabalho, planos e métodos para lidar com eles ${ }^{108}$.

No âmbito da regra pragmatista do valor das consequências, a moralidade assume um caráter marcadamente contextualista: "cada situação moral é uma única situação tendo o seu próprio e insubstituível bem" ${ }^{\prime 109}$.

Para Dewey, o justo, o certo, o bem moral, assim como a verdade, são adverbiais, de modo que só existem "quando algo tem que ser feito". Isso, por sua vez, indica a presença de um conflito dentro de uma situação inevitavelmente específica, concreta, única, de modo tal que o problema moral nunca será cópia exata de qualquer outro. Seu julgamento tem de ser, por conseguinte, necessariamente, específico.

Destarte, a solução de um conflito moral, remetendo a uma situação individualizada, com seu próprio e insubstituível bem, não pode ser dita de antemão, no geral - o que não pode senão funcionar como um leito de Procusto mutilador da diversidade experiencial. O bem de uma situação "deve ser descoberto, esboçado e alcançado sobre a base do exato mal e problema a ser retificado"110.

Os valores, os princípios e as teorias da moralidade não implicam um inventário acabado de julgamentos prévios, um "catálogo de ações tampouco um conjunto de regras a serem aplicadas como uma prescrição médica ou livro de receitas”. Dentro da concepção experimental, instrumental e pragmatista, têm seu significado e sua importância referidos

\footnotetext{
106 TEIXEIRA, Filosofia e educação, 1959.

${ }^{107}$ DEWEY, The study of ethics, 1897, p. 01; DEWEY, Reconstruction in philosophy, 2004, p. 94 e 95.

${ }^{108}$ DEWEY, Reconstruction in philosophy, 2004, p. 95, 97, 98 e 111.

109 DEWEY, Reconstruction in philosophy, 2004, p. 93; DEWEY, O desenvolvimento do pragmatismo americano, 2007, p. 236.

${ }^{110}$ DEWEY, Reconstruction in philosophy, 2004, p. 96 e 97.
} 
à experiência: "são instrumentos de discernimento; seu valor está na promoção de respostas individualizadas na situação individual"111.

É dessa forma, recusando qualquer critério moral fixo e encorajando a inteligência a "estudar os meios positivos do bem e os obstáculos à sua realização e levar adiante os esforços para a melhoria das condições", que Dewey assume, no seu programa de reconstrução da filosofia, a máxima moral do crescimento como fim. "O crescimento em si é o único fim moral"112.

Identifica, como fator significante da moralidade, o processo ativo de crescimento, de transformação e de melhoria da qualidade das experiências. Em suma, a direção para a qual se caminha. Ressalta, nesse sentido, em termos de crescimento individual: "O homem mau é o homem que, não importa quão bom ele foi, está começando a se deteriorar, a se tornar pior. O homem bom é aquele que, não importa quão moralmente sem valor ele foi, está se movendo para se tornar melhor" ${ }^{, 13}$.

Eis o critério que dispomos, superada a metafísica, para a avaliação e julgamento do valor das condutas, interações, tradições, hábitos e instituições sociais, dentre as quais as instituições democráticas e educacionais. $\mathrm{O}$ valor moral de uma experiência remete à aptidão para promover a reconstrução, de modo sempre mais enriquecido e profundo, das experiências que proporciona e o crescimento dos membros do grupo social. Dito de outra forma, indica a liberação, desenvolvimento, de modo coordenado, das potencialidades individuais, na plenitude de suas possibilidades ${ }^{114}$.

Induz, portanto, o crescimento "em geral", no sentido de que cria condições, favorece atitudes e hábitos que abrem caminhos para crescimentos subsequentes, em outras direções, para continuar crescendo. E, com isso, pressupõe e favorece a reconstrução das experiências individuais e sociais de modo a abranger in toto a comunidade. Dewey não está se referindo, portanto, à especialização cientificista tampouco ao êxito material, econômico, a despeito e, mesmo, em detrimento de outros crescimentos, em outras direções, do próprio sujeito e dos demais membros do grupo social. Isso seria imoral.

\footnotetext{
${ }^{111}$ DEWEY, The study of ethics, 1897, p. 01 e 02; DEWEY, Reconstruction in philosophy, 2004, p. 97.

112 DEWEY, Reconstruction in philosophy, 2004, p. 102 e 103.

${ }^{113}$ DEWEY, Reconstruction in philosophy, 2004, p. 101.

${ }^{114}$ DEWEY, Reconstruction in philosophy, 2004, p. 101 e 107; DEWEY, Ethics, 2008, p. 305.
} 
Afinal, para o filósofo, o conceito de crescimento "deve ter aplicação universal e não especializada e limitada"115.

1.7. Por tudo isso, a filosofia, em Dewey, é reconstruída criticamente dentro da tradição da modernidade.

Sua denúncia aos descaminhos da razão e da ciência moderna, reduzidas a uma perspectiva solipsista, individualista, cientificista, especialista, distando, desse modo, o desenvolvimento material e tecnológico do progresso moral, não o conduz, absolutamente, ao outro extremo: o abandono da razão, da ciência e da modernidade.

Pensar em termos de opostos extremos, adotando, contra o modernismo, o cientificismo e o racionalismo algum outro tipo de "ismo" é, para Dewey, um grande equívoco. Afinal, “todo movimento que pensa e age em termos de um ‘ismo’ envolve-se tão intensamente na reação contra outros 'ismos' que acaba sendo por eles controlado". Formulando a teoria reativa e negativamente, perde a oportunidade de uma "investigação abrangente e construtiva das atuais necessidades, problemas e possibilidades"116.

A filosofia deweyana mantém a aposta iluminista da emancipação da humanidade, por meio da razão, da inteligência, do conhecimento, apesar de toda sua falibilidade, de seu uso imoral em proveito de poucos e das tantas barbáries que permitiu e ocasionou.

A crítica de Dewey à modernidade não implica rechaçar seus avanços, experiências e aprendizados. Questiona, aliás, "aqueles que colocam a culpa por todos os males de nossas vidas no vapor, na eletricidade e nas máquinas". Pois, para ele, "o problema surge, antes, das ideias, ou ausência delas, em conexão com as quais os fatores tecnológicos operam"117.

Afasta-se, porém, da metanarrativa moderna, otimista e ingênua, do progresso humano como resultado necessário do desenvolvimento da ciência e da técnica ${ }^{118}$. Reconhece, no final das contas, que "Não é mais possível manter a fé simplória do

${ }^{115}$ DEWEY, Reconstruction in philosophy, 2004, p. 106 e 107; DEWEY, Experiência e educação, 2010, p. 36 e 37.

${ }^{116}$ DEWEY, Experiência e educação, 2010, p. 14, 19 e 22.

${ }^{117}$ DEWEY, The public and its problems, 1991, p. 110 e 141.

${ }^{118}$ TRINDADE, Christiane Coutheux. Educação, sociedade e democracia no pensamento de John Dewey. Dissertação (Mestrado - Programa de Pós-graduação em Educação. Área de concentração: Educação e filosofia). Faculdade de Educação da Universidade de São Paulo, 2009, p. 74. 
Iluminismo de que progresso da ciência produzirá instituições livres dissipando a ignorância e a superstição: as fontes da servidão humana e os pilares do governo opressivo" 119 .

De qualquer forma, a incredulidade em relação às metanarrativas - forma como Lyotard definiria, mais tarde, a pós-modernidade ${ }^{120}$ - é mitigada pela permanência, sim, de uma fé: a fé na humanidade, na inteligência e em seu progresso, na convivência democrática. Dewey defende, mesmo, "a formação de uma fé na inteligência como a única e indispensável crença necessária à moral e à vida social", destacando que:

(...) quanto mais se toma consciência de que a própria inteligência acrescenta alegria e dignidade à vida, tanto mais se sente pesar frente à situação em que o exercício e a alegria da razão encontram-se limitados a um grupo social restrito, fechado e técnico, e tanto mais dever-se-ia perguntar como seria possível fazer todos os homens participantes desse inestimável bem ${ }^{121}$.

Trata-se de uma crença que, por outro lado, não se referindo qualquer metahistória pré-escrita, determinando seu próprio desenrolar, feliz ou não, é caracterizada pelo comprometimento com a práxis, pela premissa da participação ativa e inteligente do sujeito na compreensão do sentido e na reconstrução das próprias experiências. Tudo isso, a partir de perspectiva quanto às possibilidades experienciais de futuro, que Dewey denomina meliorista: uma abordagem segundo a qual as condições objetivas de existência, sejam boas ou ruins, podem ser, em qualquer caso, sempre e continuamente melhoradas ${ }^{122}$.

Enfim, a razão e o conhecimento, desprovidos de bases seguras metafísicas para a afirmação da verdade e da moral, mas sem, por isso, negarem a si, persistem como o instrumento de realização do projeto de emancipação da humanidade. Agora, amparadas e comprometidas com a prática experiencial: uma experiência na qual a inteligência tem “importância moral e humana” e aparece inevitavelmente ligada à práxis comunicativa.

\section{A experiência, o pensar reflexivo e o crescimento.}

Tais características do programa filosófico deweyano, moderno e crítico da modernidade, revelam-se e se consolidam nas suas formulações sobre a experiência, o

\footnotetext{
${ }^{119}$ DEWEY, John, Freedom and culture, 1989, p.102.

${ }^{120}$ LYOTARD, The postmodern condition, 1984, p. xxiv.

${ }^{121}$ DEWEY, O desenvolvimento do pragmatismo americano, 2007, p. 242.

${ }^{122}$ DEWEY, Reconstruction in philosophy, 2004 p. 102 e 103.
} 
pensar, referido à ação, e o crescimento cognitivo e moral do indivíduo, na experiência comunicativa e reflexiva.

2.1. A ideia de experiência desempenha papel principal na filosofia reconstruída. Dewey fala de uma experiência ativa, dentro da qual a razão atua de modo experimental, planejador, criativo e reajustador.

Trata-se de concepção influenciada pelo desenvolvimento da biologia, a qual demonstrou que "onde quer que haja vida, há atividade, comportamento e a fim de que a vida possa persistir, essa atividade tem de ser contínua e adaptada ao ambiente" ${ }^{\text {"123 }}$. É o movimento do agir sobre outros elementos que compõem o ambiente, deles sofrendo, então, uma reação, que define, para Dewey, a experiência. A experiência é compreendida como a interação próxima e contínua entre o agir, o fazer e o sofrer, ser submetido às mudanças ocorridas no ambiente, em consequência da ação. Implica uma interação na qual os elementos que a constituem, o agente e o ambiente, são modificados:

Experiência se torna uma questão fundamentalmente de fazer (...) $\mathrm{O}$
organismo não fica à toa (...) $\mathrm{O}$ organismo atua de acordo com sua
própria estrutura, simples ou complexa, sobre seu ambiente. Como
consequência, as mudanças produzidas no ambiente reagem sobre o
organismo e suas atividades. A criatura viva submete-se, sofre as
consequências de seu próprio comportamento. Esta relação estreita entre
fazer e sofrer ou ser submetido à forma o que nós chamamos
experiência ${ }^{124}$.

No âmbito da experiência humana, esse agir e sofrer a reação adquire maior amplitude, somando a reflexão, o conhecimento - também eles ações - para a reconstrução das experiências $^{125}$.

$\mathrm{O}$ ato do pensar, constituído na experiência comunicativa, adquire importância fundamental na condução das experiências subsequentes. A razão não paira sobre a experiência, como pretendia a metafísica. O pensamento funciona, na realidade, como "um instrumento de ajuste ou de adaptação a uma situação ambiental particular (...) Sua origem prende-se a uma perturbação sofrida pelo organismo, que necessita restabelecer seu

123 DEWEY, Reconstruction in philosophy, 2004, p. 48. DEWEY, O desenvolvimento do pragmatismo americano, 2007, p. 236.

${ }^{124}$ DEWEY, Reconstruction in philosophy, 2004, p. 49.

125 TEIXEIRA, A pedagogia de Dewey, 1980, p. 113 e 114. 
equilíbrio com o meio"126. O conhecimento, enfim, "não é algo separado e autossuficiente, mas está envolvido no processo pelo qual a vida é mantida e desenvolvida": a razão, como já destacado, é inteligência experimental: "sugerida e testada na experiência, ela é também empregada, através de invenções, em milhares de formas para expandir e enriquecer a experiência" 127 .

Em suma, a experiência remete às "adaptativas sequências de ação, hábitos, funções ativas, conexões de fazer e ser submetido a", as quais propiciam "a base e o material para a evolução positiva da inteligência como fator organizador dentro da experiência" 128 .

Nesse sentido, destacam-se dois princípios inseparáveis, que, fundamentais à nossa experiência, determinam sua constituição.

Primeiro, o princípio da interação, de acordo com o qual "Uma experiência é sempre o que é por causa de uma transação acontecendo entre um indivíduo e o que, no momento, constitui seu ambiente". Conjuga, nesse sentido, dois fatores, em intercâmbio e com "direitos iguais": o subjetivo, daquele que a experimenta; e o objetivo, a saber, o ambiente, físico e social, definido como "quaisquer condições em interação com necessidades pessoais, desejos, propósitos e capacidades de criar a experiência que se está passando". E este último, em qualquer hipótese, remete-nos a uma interação comunicativa, mesmo quando, a partir dela, em seu solilóquio, a pessoa interage com objetos construídos em sua fantasia ${ }^{129}$.

Segundo, o princípio da continuidade. Significa que "toda a experiência tanto toma algo das experiências passadas como modifica de algum modo a qualidade das experiências que virão”. Afinal,

(...) toda a ação praticada ou sofrida em uma experiência modifica quem a pratica e quem a sofre, ao mesmo tempo em que essa modificação afeta, quer queiramos ou não, a qualidade das experiências subsequentes, pois, ao ser modificada pelas experiências anteriores, de algum modo, será outra pessoa que passará pelas novas experiências ${ }^{130}$.

\footnotetext{
${ }^{126}$ AMARAL, M. Nazaré de C. Pacheco. Dewey: filosofia e experiência democrática. São Paulo: Perspectiva, 2007 , p. 62.

${ }^{127}$ DEWEY, Reconstruction in philosophy, 2004, p. 50, 54 e 55.

${ }^{128}$ DEWEY, Reconstruction in philosophy, 2004, p. 52.

${ }^{129}$ DEWEY, Experiência e educação, 2010, p. 43 e 45.

${ }^{130}$ DEWEY, Experiência e educação, 2010, p. 35 e 36.
} 
O continuum experiencial induz, assim, a concepção cosmológica de Heráclito ${ }^{131}$, em que o universo aparece como o contínuo fluir dos elementos e seres em permanente mudança, de modo que "Em rio não se pode entrar duas vezes no mesmo" 132 . O indivíduo, submetido às mudanças sofridas pelo ambiente em decorrência da experiência, é também modificado, diante do que as experiências anteriores refletem necessariamente nas posteriores, em sua qualidade e conteúdo, num processo experiencial interativo contínuo.

Dessa forma, ao se combinarem os dois princípios, diferentes situações de interação sucedem umas às outras, levando-se algo, inevitavelmente, de uma situação anterior para a posterior. E, na perspectiva do sujeito que experiencia, conforme "passa de uma situação para outra, seu mundo, seu ambiente, se expande ou se contrai"133.

O só fato de conhecer um objeto - a experiência humana de conhecimento e reflexão - importa uma modificação simultânea no sujeito cognoscente e, na perspectiva dele, intermediada por suas experiências, na coisa conhecida, alterando-se, com isso, as relações que passam a existir entre ambos:

A árvore que era apenas objeto de minha experiência visual passa a existir de modo diverso, se entre mim e ela outras experiências se processarem, pelas quais eu a venha conhecer em outros aspectos: úteis, medicinais, de resistência, etc. Depois dessas experiências, eu e a árvore somos alguma coisa diferente do que éramos antes. Existimos de modo diverso um para o outro. Houve, através daquelas experiências uma transformação que irá permitir alterar, sob certo aspecto, o mundo em que vivo ${ }^{134}$.

Tal experiência do conhecimento remete, então, ao modo como o indivíduo passa a agir sobre o ambiente físico e social, sofrendo as consequências de sua atuação. Em qualquer dos dois casos - a reorganização meramente cognitiva ou a objetiva da experiência - alteram-se o sujeito e o seu mundo, renovando, para sempre, o continuum experiencial $^{135}$.

${ }^{131}$ ROCHA, Eliezer Pedroso da. O princípio da continuidade e relação entre interesse e esforço em Dewey. Tese (Doutorado - Programa de Pós-graduação em Educação. Área de concentração: Educação e filosofia). Faculdade de Educação da Universidade de São Paulo, 2011, p. 48 e 49.

${ }^{132}$ HERÁCLITO DE ÉFESO. Fragmentos. Sobre a natureza. Trad. José Cavalcanti de Souza. In SOUZA, José Cavalcante de (seleção de textos e supervisão). Os Pré-socráticos. Coleção Os Pensadores. São Paulo: Abril Cultural, 1973, p. 94.

${ }^{133}$ DEWEY, Experiência e educação, 2010, p. 45.

134 TEIXEIRA, A pedagogia de Dewey, 1980, p. 114.

${ }^{135}$ DEWEY, Experiência e educação, 2010, p. 45; DEWEY, O desenvolvimento do pragmatismo americano, 2007, p. 240. 
Destarte, a experiência, conceito-base no pensamento de Dewey, concebida dentro dessa interação contínua, próxima e ativa, entre o sujeito e as condições objetivas e sociais de seu ambiente, alinha-se com o próprio processo de vida. Faz-se, desse modo, na relação com o outro, na comunicação. No seu continuum, as possibilidades de abordagem subjetivas da realidade são delineadas; os hábitos de pensar, agir e conviver construídos; os horizontes de possibilidades de existência descortinados.

O modo como, historicamente, efetiva-se a experiência, de acordo com o contexto de vida concreto no qual os sujeitos se encontram - com suas tradições, ordenações, instituições, concepções e orientações axiológicas, práticas, etc. - vai sedimentando a maneira como o pensar e o agir operam e, com isso, a forma como os sujeitos concebem o ambiente e atuam sobre ele, moldando e reconstruindo sua experiência.

O resultado, positivo ou negativo, desse processo, dependerá, de qualquer forma, da qualidade das experiências pelas quais passamos. Pois, no continuum experiencial, diante do que só podemos experienciar o mundo sob a perspectiva do que somos no desenrolar de nosso processo vital, fica claro, com Dewey, que a direção para a qual caminham as experiências, o modo como se renova e se transforma seu conteúdo, estão diretamente relacionados à qualidade com que, em cada momento, são atualizadas e experienciadas ${ }^{136}$.

2.2. Nesse cenário, a atividade do pensar e, a partir da ideia, do pensamento formado, a ação sobre o ambiente e a interação social, assumem um lugar e um sentido bastante precisos. São interpretados como hábitos formados a partir da experiência.

Para Dewey, em consonância com a psicologia meadiana ${ }^{137}$, a inteligência, emergida da experiência comunicativa, indica uma conversação interna que prepara a ação social. Há de atuar ativa, planejadora e construtivamente, dentro da própria experiência.

O pensar, desse modo, não deve se limitar, em sua operação, à assimilação acrítica, desatenta, descuidada de ideias, crenças pelo seu valor superficial, sem a consideração dos fundamentos que a embasam e as consequências a que levam. Pois isso conduz a um agir e a uma experiência social irrefletida, em que o sujeito permanece submerso e preso às

${ }^{136}$ DEWEY, Experiência e educação, 2010, p. 38 e 46.

${ }^{137}$ MEAD, Mind, self and society, 1992, p. 133, 140 e 141. 
normas, valores, atitudes e instituições sociais, ou, ainda, escravizado pelo acaso, à fatalidade e a seus impulsos libidinais incontidos ${ }^{138}$.

O pensar, em seu melhor sentido, o reflexivo, racional, coadunado com a atitude científica, apresenta-se como um complexo processo de solução de dificuldades enfrentadas no curso da experiência. Nas palavras de Mead, com quem Dewey compartilhou tal perspectiva psicológica funcionalista ${ }^{139}$ :

A mente, como pensamento construtivo, reflexivo ou solucionador de problemas, é o meio, o mecanismo ou o instrumento adquirido socialmente, por meio do qual o indivíduo resolve os vários problemas de ajustamento ao ambiente, que surgem para confrontá-lo no curso da experiência. A mente ou o pensamento é, também (...) o instrumento por meio do qual a reconstrução social é efetivada por esses indivíduos ${ }^{140}$.

Tem origem, sempre, em específicos conflitos na experiência que geram perturbações. Na metáfora de Dewey, o processo de pensar começa numa forked-road situation, "uma situação que é ambígua, que apresenta um dilema, que propõe alternativas". Trata-se, em rigor, como destaca, de um problema que não é, ainda, atual, presente, mas iminente, diante do qual "observando os sinais do que o problema é, estamos ao mesmo tempo supondo, prevendo - em suma, formando uma idéia, tomando consciência do significado" $" 141$.

Envolve, de qualquer forma, num primeiro momento, "um estado de perplexidade, hesitação, dúvida" e, dada a dificuldade, o próximo passo é uma "pausa" no curso da ação, para inferir e encontrar uma resposta, "uma espécie de antecipação ou prognóstico do que está vindo". O pensar reflexivo exige a aplicação da fórmula "pare e pense", com a inibição temporária e adiamento da ação. Demanda uma atitude de conclusão ou julgamento suspenso, diante do que, refreamos a reação impulsiva e buscamos apreender o significado do problema na experiência, as condições e circunstâncias em que se efetiva, as conexões entre as ações e suas possíveis consequências, e, refletindo sobre sua resposta,

\footnotetext{
${ }^{138}$ DEWEY, How we think, 1997, p. 01, 04, 05, 06 e 67; FREUD, Sigmund. Psicologia das massas e análise do eu. In Obras completas. Volume 15. Psicologia das massas e análise do eu e outros textos (1920-1923). Trad. Paulo César de Souza. São Paulo: Cia das Letras, 2011, p. 43.

139 JOAS, Pragmatism and social theory, 1992, p. 20.

${ }^{140}$ MEAD, Mind, self and society, 1992, p. 308.

${ }^{141}$ DEWEY, How we think, 1997, p. 11 e 12; DEWEY, Reconstruction in philosophy, 2004, p. 82.
} 
selecionamos uma dentre as possibilidades e alternativas de solução que se abrem, na situação $^{142}$.

A ideia então formada é concebida a partir dos fatos e elementos presentes na experiência, mediados pelos conhecimentos e pelas habilidades do sujeito, frutos de suas experiências anteriores, isto é, daquele "reservatório" de conhecimentos prévios, em permanente revisão, "obtido parcialmente pela recordação, como também pelas informações, conselhos e advertência por parte daqueles que já possuam uma maior experiência"143.

Nesse sentido, novamente com Mead, a inteligência implica, fundamentalmente, a habilidade de resolver problemas na experiência presente, em termos de suas possíveis consequências futuras, considerando as experiências do passado, encontrado no mundo presente. Isto é, "a habilidade de resolver problemas do comportamento presente, à luz ou em função do passado e do futuro; ela envolve tanto a memória como a previsão"144

O pensar reflexivo, em suma, corresponde à operação na qual fatos presentes, averiguados sugerem outros fatos - não diretamente verificados -, de modo tal a induzir a convicção no segundo com base ou autorização do primeiro. Implica, enfim, na inibição do ação imediata, rotineira ou impulsiva, na união da observação com a memória, o "coração da reflexão", a "busca do ausente a partir do presente", a fim de "colmatar uma lacuna na experiência" 145 .

Dewey distingue cinco passos na operação do pensar reflexivo.

Primeiro, a mencionada dificuldade efetivamente experienciada. Trata-se do estímulo e fator determinante do pensamento, presente desde sempre no ser humano. E isso mesmo no bebê, cujo problema primário, destaca o autor, é "o controle de seu corpo como uma ferramenta que assegura conforto e ajustamento eficaz ao seu ambiente, físico e social" e em quem, como consequência, o pensar, num nível ainda rudimentar, corresponde ao processo de seleção de movimentos, inicialmente instintivos, e sua

\footnotetext{
${ }^{142}$ MEAD, Mind, self and society, 1992, p. 99; DEWEY, How we think, 1997, p. 09, 12 e 74; DEWEY, Reconstruction in philosophy, 2004, p. 82; DEWEY, Experiência e educação, 2010, p. 66; DEWEY, Democracy and education, 1916, p. 178.

${ }^{143}$ DEWEY, How we think, 1997, p. 12; DEWEY, Reconstruction in philosophy, 2004, p. 82; DEWEY, Experiência e educação, 2010, p. 70.

${ }^{144}$ MEAD, Mind, self and society, 1992, p. 100 e 116.

${ }^{145}$ DEWEY, How we think, 1997, p. 08, 09, 26 e 80; DEWEY, Experiência e educação, 2010, p. 66.
} 
organização com vistas a um fim, como agarrar um objeto e manuseá-lo, movimentar o corpo, engatinhar e assim por diante ${ }^{146}$.

Tendo origem em um problema, o pensar "não é um caso de combustão espontânea; ele não ocorre sobre 'princípios gerais'; há algo específico que o ocasiona e o evoca”. E algo, uma dificuldade, que emerge da experiência do próprio sujeito, no curso de sua ação, causando-lhe perplexidade e colocando o pensar como o caminho necessário para sua solução. Enfim, "o problema determina o fim do pensamento e o fim controla o processo de pensar". Por conseguinte, o homem "não pensa quando não tem problemas com os quais lidar, nem dificuldades a superar", implicando, nessa linha, uma experiência irrefletida aquela desprovida de dificuldades ou, ainda, aquela em que, em meio a dificuldades, as soluções são preditas, impostas de fora, por terceiros ${ }^{147}$.

Segundo, a localização e definição do problema. Trata-se de passo normalmente misturado ao anterior. Em casos de perplexidade incomum, porém, a dificuldade pode se apresentar, primeiro, como um choque, um sentimento de inesperado, exigindo, então, "observações deliberadamente calculadas para trazer à luz o que está em dificuldade, ou para tornar claras as características específicas do problema". E conclui, "Em grande medida, a existência ou não existência deste (segundo) passo faz a diferença entre a reflexão adequada ou inferência crítica salvaguardada e o pensar não controlado"148.

Terceiro, a sugestão, a inferência. Corresponde à ideia, ao pensamento, à hipótese teórica que funciona como plano de ação; ferramenta para a solução de lacunas da experiência; instrumento "para a ativa reorganização do ambiente dado, para a remoção de específicos problemas e perplexidades" $"$.

A situação de perplexidade invoca algo não presente aos sentidos, de forma que o conteúdo da sugestão é prospectivo. E, para sua formulação, o sujeito somente dispõe daquele "estoque" de experiências e conhecimentos anteriores, que intermediam sua relação com o ambiente. Eis o material para o pensamento ${ }^{150}$. Isso leva a três considerações importantes.

\footnotetext{
${ }^{146}$ DEWEY, How we think, 1997, p. 157 e 158.

${ }^{147}$ DEWEY, How we think, 1997, p. 12; DEWEY, Reconstruction in philosophy, 2004, p. 80.

${ }^{148}$ DEWEY, How we think, 1997, p. 73 e 74.

${ }^{149}$ DEWEY, How we think, 1997, p. 72; DEWEY, Reconstruction in philosophy, 2004, p. 89 e 90.

${ }^{150}$ DEWEY, O desenvolvimento do pragmatismo americano, 2007, p. 235; DEWEY, How we think, 1997, p. 12.
} 
Em primeiro lugar, o fato de que, sem experiências, sem conhecimentos e habilidades que, em alguma medida, aproximem o sujeito da solução do problema enfrentado, que o permitam inferir uma resposta adequada, a "confusão permanece mera confusão. Não há nada a partir do que inferir a fim de esclarecê-la"151:

Todo julgamento, toda inferência reflexiva pressupõe alguma falta de compreensão, uma parcial ausência de significado. Refletimos para que possamos nos apoderar do significado adequado e completo do que acontece. Entretanto, algo já deve ser entendido, a mente deve estar na posse de algum significado que ela dominou, ou então pensar é impossível ${ }^{152}$.

A segunda consideração, vinculada à anterior, é a de que a aptidão dos sujeitos para uma resposta adequada ao problema, expandindo, aprofundando e reorganizando o significado do universo experiencial, está diretamente vinculada à sua experiência desse mesmo universo, suas habilidades, conhecimentos, de seu hábito de pensar, enfim, ao que é naquele momento - um ser, de qualquer forma, em permanente reconstrução.

Por último, o fato de que, independentemente das experiências do sujeito, a ideia sugerida como resposta ao problema implica, em qualquer hipótese, um caminhar "do que é presente ao que é ausente" e, portanto, um salto, em alguma medida, aventureiro, arriscado, falível. Tem, inevitavelmente, "a propriedade do que não pode ser absolutamente garantido com antecedência, não importa quais precauções sejam tomadas". Está, enfim, inevitavelmente, sujeito ao erro:

Ao mesmo tempo em que o poder do pensamento liberta-nos da submissão servil dos instintos, apetite e rotina, ele traz consigo a ocasião e possibilidade do engano e do erro. Elevando-nos acima do irracional, ele nos abre à possibilidade de falhas nas quais o animal, limitado ao instinto, não cai ${ }^{153}$.

Voltando aos passos do pensar, o quarto é o desenvolvimento, no plano ainda ideal e hipotético, por meio do raciocínio, dos rumos e implicações da sugestão ${ }^{154}$.

Mas o ato de pensar não pode parar na ideia formada: “a elaboração pelo raciocínio pode fazer a ideia sugerida muito rica e plausível, mas ela não determina a validade da ideia", isto é, a sua verdade ou, no âmbito moral, o seu bem. Estes devem ser aferidos, tentativa e necessariamente, na prática, em sua aptidão para resolver o conflito, a lacuna, o problema experienciado. Desse modo, como quinto e último passo, aparece a conclusão,

\footnotetext{
${ }^{151}$ DEWEY, How we think, 1997, p. 12.

${ }^{152}$ DEWEY, How we think, 1997, p. 119.

${ }^{153}$ DEWEY, How we think, 1997, p. 19 e 75.

${ }^{154}$ DEWEY, How we think, 1997, p. 72 e 75.
} 
com a experimentação, a verificação prática da ideia conjectural, conduzindo à confirmação ou à rejeição experimental do processo de pensar empreendido ${ }^{155}$.

Para ser completo, portanto, o pensar deve terminar onde tudo começou, no domínio da práxis, da ação interrompida pelo problema experienciado. Evidencia-se, assim, o movimento duplo do processo reflexivo: um movimento a partir dos problemas emergidos da experiência em direção às ideias, isto é, às sugestões de significado e de resposta; e outro, na sequência, a partir delas, de volta à situação problemática, experimentando as ideias hipoteticamente cogitadas ${ }^{156}$.

É nesse plano prático, enfim, que pode ser aferida a pretensão de validade da ideia, marcadamente instrumental: "Como é o caso de qualquer ferramenta, seu valor reside não em si mesma, mas na sua capacidade de funcionar, mostrada nas consequências de seu uso". Assim, se têm sucesso nessa empreitada, eliminando a incerteza, a confusão, o conflito, são válidas, boas, verdadeiras; porém, se, colocados em ação, falham, são inválidas, falsas ${ }^{157}$.

E, dessa forma, o pensar reflexivo pode se constituir e se atualizar como operação emancipadora do homem, possibilitando-lhe a solução dos problemas vivenciados nas experiências cotidianas, ampliando e aprofundando seu sentido, reconstruindo-a, de modo positivo e enriquecido, sem ser empurrado para a ação irrefletida, pela força do hábito rotineiro, de impulsos libidinais e do acaso ${ }^{158}$.

2.3. No âmbito do processo experiencial contínuo, a partir do qual o pensar, o agir e o conviver se formam e se tornam habituais $^{159}$, tem lugar o crescimento cognitivo e moral do sujeito.

De acordo com sua perspectiva social de constituição do indivíduo e da mente, bem como com sua abordagem cognitivista da moral, o crescimento, em Dewey, aparece como o processo em que, na experiência comunicativa, o sujeito torna-se - ou, pelo menos, pode tornar-se - cada vez mais social, mais racional e mais moral ${ }^{160}$.

\footnotetext{
${ }^{155}$ DEWEY, How we think, 1997, p. 72, 77, 79, 96 e 108

${ }^{156}$ DEWEY, How we think, 1997, p. 72.

${ }^{157}$ DEWEY, Reconstruction in philosophy, 2004, p. 83, 89 e 90; AMARAL, Dewey, 2007, p. 62 e 63.

${ }^{158}$ DEWEY, How we think, 1997, p. 14, 15 e 67.

${ }^{159}$ DEWEY, The public and its problems, 1991, p. 160.

${ }^{160}$ KOHLBERG, La Democracia en la escuela secundaria, 1992, p. 04; DEWEY, Ethics, 2008, p. 12 e 13.
} 
Distingue três níveis de conduta, na direção da autonomia cognitiva e moral.

O primeiro nível é o pré-moral ou pré-convencional, em que a conduta é motivada por impulsos e necessidades biológicas, físicas ou, de qualquer modo, não morais, mas que, ainda assim, têm consequências importantes para a moral ${ }^{161}$.

Como destaca Dewey, "Nós começamos a vida sob a influência de apetites e impulsos e da resposta direta aos impulsos imediatos de calor e frio, conforto e dor, luz, barulho, etc.”. E, a partir da daí, em função também da própria dependência absoluta e impotência do bebê, o eu e o mundo passam a ser constituídos mediados por outras pessoas (a mãe, o pai, a pessoa mais velha, em geral), que "determinam quais experiências a criança deve ter; eles instruem-na quanto ao significado do que ela faz e sofre". Desse modo, a criança, progressivamente, ingressa no universo da linguagem e, a partir dele, como um si mesmo, num mundo constituído de objetos físicos e culturais ${ }^{162}$.

As perspectivas, as expectativas, as instituições, os hábitos e as tradições do grupo social vão sendo infundidas na pessoa em crescimento, no âmbito de suas experiências, por meio de estímulos, demandas, determinações, aprovações, reprovações, castigos e prêmios. Constituem, assim, os princípios e critérios de que dispõe, (re)construtivamente, para a percepção e interpretação dessas mesmas experiências. Com isso,

As coisas vêm a ela (a criança) vestidas em linguagem, não em sua nudez física, e esse traje de comunicação faz dela uma participante nas crenças deles (os membros do grupo social) sobre ela. Essas crenças, vindo a ela, como tantos fatos, formam sua mente; fornecem os centros sobre os quais suas próprias explorações e percepções pessoais são ordenadas. Aqui temos "categorias" de conexão e unificação tão importantes como aquelas de Kant, mas empíricas, não mitológicas ${ }^{163}$.

Enfim, correspondem aos fatores que levarão à mudança, na criança, das tendências meramente biológicas, naturais, em traços de um "eu com valor e significação moral"164.

É nesse sentido que Mead refere a formação da personalidade à internalização e organização, pelo sujeito, das atitudes comuns do grupo, o outro generalizado:

Uma pessoa é uma personalidade porque ela pertence a uma comunidade, porque ela assume as instituições daquela comunidade em sua própria conduta. Ela assume sua linguagem como o meio pelo qual forma sua personalidade e, então, por meio do processo de tomada dos papéis que

\footnotetext{
${ }^{161}$ DEWEY, Ethics, 2008, p. 12.

162 DEWEY, Reconstruction in philosophy, 2004, p. 54; DEWEY, Ethics, 2008, p. 169

${ }^{163}$ DEWEY, Reconstruction in philosophy, 2004, p. 54.

${ }^{164}$ DEWEY, Ethics, 2008, p. 303.
} 
todos os outros provêm, ela vem a apreender a atitude dos membros da comunidade. Esta é, em certo sentido, a estrutura da personalidade ${ }^{165}$.

A personalidade emerge, assim, na experiência, essencialmente como me, isto é, o aspecto convencional do indivíduo, constituído pelo "conjunto organizado das atitudes dos outros que o sujeito assume", com "aqueles hábitos, aquelas respostas que todo mundo tem; do contrário, o indivíduo não poderia ser membro da comunidade". A isso, a pessoa em formação reage, na expressão de si mesmo, como $e u^{166}$.

Dessa forma, Dewey apresenta, como segundo nível de conduta, o heterônomo ou convencional. Nele, o indivíduo está inserido no universo cultural do grupo social, compartilhando suas experiências, seus valores, seus hábitos comuns. Participa do pano de fundo de entendimento mútuo, despercebida e inconscientemente assimilado, implícito e pressuposto, em que ocorre a comunicação e a interação social ${ }^{167}$.

Nesse estágio, porém, circunscrito o pensamento a esse mobiliário mental captado acriticamente, "não sabemos como", o indivíduo ainda "aceita com relativamente pequena reflexão crítica os padrões e formas de seu grupo, tal como incorporados nas tradições e costumes" $" 168$. Na linha da filosofia kantiana, sujeita-se a convenções, normas heterônomas, alheias à própria razão, pois dadas, de fora, pelo grupo ${ }^{169}$.

Finalmente, no terceiro nível de conduta, da autonomia, o sujeito em crescimento, superando a personalidade e a experiência convencional, da qual emergiu, "pensa e julga por si, considera se o propósito é bom ou certo, decide e escolhe, não aceitando os padrões de seu grupo sem reflexão" ${ }^{\prime 170}$.

A criança iniciou seu processo de descobrimento e inferência do sentido do mundo, com uma manifestação física de curiosidade: um extravasamento de vida, "uma expressão de uma energia orgânica abundante" e, assim, "uma inquietação fisiológica (que) leva a criança a estar 'em tudo', agarrando, cutucando, batendo, bisbilhotando". A partir disso, ingressando no universo de linguagem, desenvolve um segundo nível de curiosidade, de caráter social. Começa "Quando a criança aprende que pode apelar aos outros para alargar seu estoque de experiências, de modo que, se os objetos não respondem de modo

\footnotetext{
${ }^{165}$ MEAD, Mind, self and society, 1992, 154 e 162.

${ }^{166}$ MEAD, Mind, self and society, 1992, p. 175, 197 e 200.

${ }^{167}$ DEWEY, How we think, 1997, p. 214.

${ }^{168}$ DEWEY, How we think, 1997, p. 04; DEWEY, Ethics, 2008, p. 12.

${ }^{169}$ KANT, Emmanuel. Fundamentação da metafísica dos costumes. Lisboa: Edições 70, 2008, p. 79.

${ }^{170}$ DEWEY, Ethics, 2008, p. 12.
} 
interessante aos seus experimentos, ele pode recorrer a pessoas para fornecer materiais interessantes". E assim, o "Por quê?" se torna o "sinal infalível da presença da criança". Finalmente, no vislumbrar que os fatos observados e as respostas tradicionais não são "toda a história", o sujeito pode chegar ao nível superior da curiosidade, a intelectual: a inquietação a partir da qual pode reconstruir o significado das experiências e vivenciá-las, com cada vez mais autonomia ${ }^{171}$.

Com a reorganização de suas experiências e de seu estoque de conhecimentos e aptidões, o indivíduo, no estágio da autonomia, habilita-se ao pensar reflexivo e, por meio desse hábito, consegue atribuir, por si, sentidos de modo mais denso e profundo. Pode, então, atuar inteligentemente na direção de sua experiência e na solução dos conflitos em seu curso ${ }^{172}$.

A formação social da personalidade conduz, ou, ao menos, permite que, em seu crescimento, o sujeito, mais do que progredir para uma conduta mais racional, mais social e mais moral sob o ponto de vista do grupo, possa, com seu pensar reflexivo, distanciar-se dos valores, experiências e instituições sociais. E isso ao ponto de emergir, em sua experiência, a colisão entre o eu e os outros, no que se refere à verdade e, no plano moral, ao valor, o bem ou mal da experiência humana ${ }^{173}$.

O pensar reflexivo, objetificando e questionando o universo cultural e linguístico do grupo social, pressupõe, de qualquer forma, que o indivíduo participe dessa linguagem e dessa cultura, dispondo de ferramentas intelectuais e dos sentidos da experiência, por elas proporcionadas ${ }^{174}$. Pode, então, em relação aos problemas e conflitos morais concretos experienciados em seu agir, avaliá-los, crítica e inteligentemente, conferindo-lhes sentido e participando da pesquisa cooperativa e do discurso, em busca de soluções moralmente boas, adequadas, em termos de reconstrução positiva das experiências ${ }^{175}$.

A autonomia moral, para Dewey contrapondo-se à heteronomia, como em Kant, distingue-se da abordagem deste último ${ }^{176}$, pois é referida ao processo construtivo de crescimento do sujeito histórico, concreto, em sua experiência social.

\footnotetext{
${ }^{171}$ DEWEY, How we think, 1997, p. 30 a 33.

${ }^{172}$ DEWEY, Reconstruction in philosophy, 2004, p. 106.

${ }^{173}$ DEWEY, O desenvolvimento do pragmatismo americano, 2007, p. 236; DEWEY, Ethics, 2008, p. 14.

${ }^{174}$ MEAD, Mind, self and society, 1992, p. 73 e 74.

${ }^{175}$ DEWEY, Ethics, 2008, p. 12 e 14.

${ }^{176}$ KANT, Fundamentação da metafísica dos costumes, 2008, p. 14 e 79.
} 
Tudo isso, enfim, num processo de incremento de liberdade, de autonomia cognitiva e moral, intersubjetivamente construída e praticada, e, assim, de emancipação. A filosofia deweyana confere destaque à liberdade de inteligência, a "genuína liberdade": a competência e o "poder mental de exercício independente, emancipado dos cordões condutores dos outros" para a avaliação, o julgamento, a significação, a direção e a reconstrução positiva da experiência comunicativa, na qual o sujeito se constituiu ${ }^{177}$.

Trata-se, de qualquer forma, de uma liberdade que, realizando-se, ativamente, em comunicação, aproveitando seu potencial de aprendizagem e de desenvolvimento do saber, e em vista da melhoria das experiências, na direção do crescimento, é inseparável da noção de responsabilidade. Liberdade e responsabilidade, em Dewey, são compreendidas dentro desse sentido moral, "conectado com possibilidade de crescimento, aprendizado e modificação da qualidade" ${ }^{178}$.

Finalmente, importa recordar, nesse processo, que, de acordo com a concepção moral deweyana, o crescimento não tem um termo final preestabelecido. Ele é o fim. Não existe um padrão de ego que determine o ponto fixo de todo o desenvolvimento. Compreendido em termos dinâmicos, "Cada eu vivo age e é afetado, em contrapartida, pelo que faz. Toda ação voluntária é um refazer do $e u$, visto que cria novos desejos, instiga novos modos de comportamento, traz à luz novas condições que instituem novos objetivos"179. E nessa permanente reconstrução, é afetado "não apenas a personalidade, mas também o ambiente que auxilia em sua constituição; isto é, implica uma visão de evolução na qual o indivíduo afeta seu próprio ambiente tanto quanto é afetado por ele" ${ }^{\text {180 }}$.

Assim, no âmbito do processo de crescimento cognitivo e moral, ao lado da determinação subjetiva do sentido ambiente, pelo sujeito, mediada pela experiência social e em permanente reconstrução, soma-se a reconstrução objetiva, do ambiente físico e social, em comunicação. As maiores habilidades, conhecimentos e experiências, permitindo um pensar reflexivo e crítico, possibilitam uma ação mais inteligente sobre o

\footnotetext{
${ }^{177}$ DEWEY, How we think, 1997, p. 63, 66 e 67; DEWEY, Experiência e educação, 2010, p. 63, 66 e 68. A liberdade de inteligência, complementa Dewey, não pode ser separada da liberdade de ação externa da atividade; porém, esta é visto não como um fim em si, mas como meio "de liberdade de julgamento e de poder para colocar em prática decisões deliberadamente tomadas" (DEWEY, Experiência e educação, 2010, p. 63 e 65$)$.

${ }_{178}$ DEWEY, Ethics, 2008, p. 305.

${ }^{179}$ DEWEY, Ethics, 2008, p. 306.

${ }^{180}$ MEAD, Mind, self and society, 1992, p. 214.
} 
ambiente, reconstruindo-o social, comunicativa e positivamente: o crescimento em geral, promotor de outros crescimentos, em outras direções, de todo o grupo social. A reconstrução subjetiva e objetiva permanente das experiências, com sua compreensão sempre mais profunda, aliada a ações cada vez mais inteligentes, implica experiências posteriores de maior qualidade, trazendo, concomitante e incessantemente, novas questões, mais profundas, a serem solucionadas por sujeitos mais aptos a lidar com elas ${ }^{181}$.

Enfim, nesse continuum experiencial positivo, não determinado por qualquer metanarrativa histórica, e, assim, de forma nenhuma necessário, a reconstrução social e a reconstrução da personalidade aparecem como "dois lados de um mesmo processo - o processo de evolução social humana"182.

2.4. A constituição social da individualidade e o pensar, agir e conviver reflexivos assim como sua deturpação irrefletida - são habilidades e hábitos construídos e reconstruídos, paulatinamente, a partir das experiências de vida. Tornam-se habituais dentro de certas linhas, perspectivas e direções experienciais, traçadas sob a influência dos costumes e tradições do grupo social ${ }^{183}$.

Formado no âmbito das experiências, o modo como o hábito determina os canais pelos quais o pensar opera influencia a forma, positiva ou negativa, como o sujeito atuará sobre seu ambiente. Os hábitos de pensar, agir e conviver e a experiência combinam-se, por conseguinte, numa correlação de influência recíproca, em que aparecem como causa e efeito permanente um do outro. Nesse processo experiencial, o crescimento cognitivo e moral dos sujeitos e da comunidade como um todo não está, absolutamente, predeterminado.

Educação e democracia não podem ser concebidas e praticadas sem a percepção clara dessa correlação. Devem, por isso, para Dewey, ser compreendidas no movimento contínuo, gradual e positivo de formação e desenvolvimento da individualidade e de melhoria e enriquecimento das experiências sociais.

${ }^{181}$ DEWEY, Reconstruction in philosophy, 2004, p. 106 e 107; DEWEY, Experiência e educação, 2010, p. $36,37,48$ e 51 .

${ }^{182}$ MEAD, Mind, self and society, 1992, p. 309.

${ }^{183}$ DEWEY, The public and its problems, 1991, p. 159 e 160. 
Nesse processo, a força dos hábitos, que dominam a reflexão-ação humana, e a força das condições objetivas, deles perpetuadores, em que se dá a experiência - todos trazidos do passado e moldadas ao longo da história - não podem ser subestimadas. Asseguram duplamente a continuidade e explicam porque "quanto mais as coisas mudaram, mais elas permaneceram as mesmas". No campo da vivência democrática, esclarecem porque "ao invés da completa revolução esperada como resultado dos mecanismos políticos democráticos, houve, principalmente, somente a transferência do poder de uma classe para outra"184.

O que temos em mãos para desenvolver novas ideias são as antigas ferramentas. $\mathrm{O}$ que permite construir novas e melhores experiências no futuro, como destacado, são justamente as experiências passadas. Destarte, são evidentes as dificuldades inerentes ao desfazimento dos velhos hábitos e à superação do me convencional, habitual, formado a partir da tradição cultural.

Daí porque as mudanças profundas não serem possíveis de pronto. Daí a desrazão da obsessiva pretensão, tipicamente moderna, de recomeçar sempre do zero ${ }^{185}$, num "retorno" a uma tabula rasa que possibilitasse a criação de uma nova ordem das coisas e mentes ${ }^{186}$.

Experiências educativas e sociais, no sentido da consolidação e aprofundamento da democracia, indicam uma mudança processual de direção, uma caminhada gradual e progressiva. E isso no âmbito do processo da interação entre os sujeitos, em seu ambiente social, em que todos se transformam e modificam um ao outro, num continuum experiencial. Só assim as vivências anteriores e aquilo que delas se extrai em termos de conhecimento e habilidades positivas, podem ser levadas inteligentemente para a compreensão, a vivência e a reconstrução das experiências subsequentes, sempre com maior qualidade cognitiva e moral.

\footnotetext{
${ }^{184}$ DEWEY, The public and its problems, 1991, p. 161.

${ }^{185}$ BAUMAN, Zygmunt. A modernidade líquida. Trad. Plínio Dentzien. Rio de Janeiro: Jorge Zahar, 2001, p. 36.

${ }_{186}$ DEWEY, The public and its problems, 1991, p. 162; DEWEY, Reconstruction in philosophy, 2004, p. 43 e 54; DEWEY, Ethics, 2008, p. 307.
} 


\section{O modelo deweyano de democracia}

A democracia, em Dewey, é a ambiência em que pode se efetivar o projeto emancipatório de modernidade.

Não se reduz, absolutamente, à organização governamental, abrangida, pelo autor, no âmbito de um modelo teórico ampliado e enriquecido de conteúdo. A democracia é apresentada como um ideal social e moral que remonta e se confunde com uma experiência anterior ao momento político da vida social: a experiência comunitária ${ }^{187}$.

Nela, a sociedade civil, ou, como prefere, o público, atento às consequências das interações, positivas ou prejudiciais, que atingem o bem-estar dos demais membros da sociedade, reconhece-se, organiza-se e atua em vista da regulamentação dessas consequências, da coordenação social e, enfim, da solução discursiva e compartilhada de problemas comuns. Vale-se, então, instrumentalmente, de uma estrutura governamental ${ }^{188}$.

Para tanto, em conformidade com sua reconstrução da filosofia, Dewey destaca a indispensabilidade, por parte dos cidadãos, do pensar e agir reflexivos, com atitude científica, e seu exercício efetivo no espaço público comunicativo e cooperativo ${ }^{189}$.

A democracia, destarte, expressa-se não em termos de instituições políticas isoladas, mas, fundamentalmente, "em atitudes dos seres humanos e é medida pelas consequências produzidas em suas vidas". O significado, o valor moral da organização democrática vincula-se, assim, à ciência moderna, em sua qualidade de um hábito da mente reflexivo, investigativo, experimental, falibilista, metódico no enfrentamento de problemas comuns. E se atualiza na comunicação, como processo de busca cooperativa da verdade e do justo. Efetiva-se, nesse sentido, na sua aptidão de contribuir para melhores experiências sociais, possibilitando o crescimento contínuo de cada membro da sociedade, sem distinção de cor, sexo, classe ou status econômico ${ }^{190}$.

Dewey, em suma, está convicto de que as organizações democráticas, "proporcionam uma melhor qualidade de experiências humanas, consideravelmente mais acessíveis e proveitosas, do que as formas não democráticas e antidemocráticas de vida

${ }^{187}$ DEWEY, The public and its problems, 1991, p. 82, 83, 148, 211 e 213.

188 DEWEY, The public and its problems, 1991, p. 12, 27, 28 e 35; HONNETH, Democracy as reflexive cooperation, 1998, p. 774.

${ }^{189}$ DEWEY, The public and its problems, 1991, p. 166, 167, 184 e 218.

190 DEWEY, Freedom and culture, 1988, p. 97; DEWEY, Reconstruction in philosophy, 2004, p. 107; TRINDADE, Educação, sociedade e democracia no pensamento de John Dewey, 2009, p. 76 e 77. 
social”. Com "a consulta mútua e as convicções alcançadas pela persuasão, possibilitam uma melhor qualidade de experiência, do que a que pode ser obtida por qualquer quantidade de outras experiências" ${ }^{\prime 191}$.

3.1. Para o delineamento completo do sentido da democracia, a filosofia social deweyana inicia com o conceito de público, em torno do qual é construída uma teoria do Estado, de modo marcadamente pragmatista, como "teoria que enfatiza as consequências da atividade como a questão essencial" ${ }^{192}$.

O ponto de partida, nesse sentido, é a constatação básica de que "as ações humanas têm consequências sobre outras pessoas, de que parte delas é percebida e de que tal percepção leva a um esforço para controlar as ações de modo a assegurar certas consequências e evitar outras". E tais consequências, complementa o autor, podem ser de dois tipos: "aquelas que afetam as pessoas diretamente envolvidas na transação e aquelas que afetam outras pessoas, além das imediatamente envolvidas" 193.

A noção de público e a linha contextual, processual e experimentalmente traçada que o distingue do que é privado emerge, então, da identificação de consequências do segundo tipo mencionado, cujo alcance e importância tornam necessário seu controle, seja pela inibição, pela promoção ${ }^{194}$ :

Quando as consequências de uma ação limitam-se ou são entendidas como limitadas sobretudo às pessoas nela diretamente envolvidas, a transação é privada (...) presumivelmente, as consequências da vantagem ou do dano não se estendem além de A e B; a atividade fica entre eles; ela é privada. Já se for constatado que as consequências da conversação estendem-se para além dos dois diretamente envolvidos, que ela afeta o bem-estar de muitos outros, o ato adquire uma capacidade de público ${ }^{195}$.

Constitui, portanto, a origem do público, de um lado, a existência de consequências que se projetam de modo importante, invasivo, para além das pessoas diretamente envolvidas na ação conjunta; a existência de conflitos e problemas de coordenação social, portanto; de outro, sua percepção por "aqueles que são afetados pelas consequências

\footnotetext{
${ }^{191}$ DEWEY, Experiência e educação, 2010, p. 34 e 35.

192 DEWEY, The public and its problems, 1991, p. 12 e 65.

${ }^{193}$ DEWEY, The public and its problems, 1991, p. 12.

194 DEWEY, 1991, p. 15. Dewey enumera, como fatores que conferem importância às consequências: “a característica do longo alcance das consequências, no tempo ou no espaço; sua natureza estável, uniforme e recorrente; e sua irreparabilidade" (DEWEY, The public and its problems, 1991, p. 64).

${ }^{195}$ DEWEY, The public and its problems, 1991, p. 12 e 13.
} 
indiretas da transação", de modo a considerar "necessário tê-las sistematicamente sob cuidado": um conjunto de pessoas com o interesse comum em controlar tais consequências e os problemas delas decorrentes, e que formam, desse modo, um público ${ }^{196}$.

Evidentemente, diante da complexidade e heterogeneidade das relações humanas; da contingência de suas consequências e dos problemas que podem envolver; da variedade incalculável de perspectivas histórico-culturais pelas quais podem ser percebidas e avaliadas; não há que se falar num único e homogêneo público, compondo organicamente a sociedade, com idênticos interesses e valores. Mais do que o público, há muitos públicos:

(...) as ações conjuntas que possuem consequências indiretas, graves e duradouras são de uma extensão sem comparação, e se entrecruzam gerando seu grupo próprio de pessoas especialmente afetadas, com pouco em comum para que esses diferentes públicos sejam unidos num único todo integrado ${ }^{197}$.

A sociedade é, assim, compreendida dentro de uma concepção pluralista. É somente um nome abstrato, coletivo que remete não a uma única organização, mas a um aglomerado de interações e associações, ou ainda, a um "processo de associação". Significa "associação, reunir-se em relação e ação conjunta para a melhor realização de qualquer forma de experiência que é enriquecida e confirmada sendo comunicada e compartilhada". Enfim, no plano concreto,

(...) há sociedades, associações, grupos de um número imenso de espécies, com diferentes vínculos e instituindo diferentes interesses. Podem ser gangues, bandos de criminosos; clubes (...) organizações científicas e profissionais; partidos políticos e alianças dentro deles; famílias; denominações religiosas; corporações e parceiros de negócios; e assim por diante numa lista sem fim ${ }^{198}$.

Nesse cenário complexo, de qualquer forma, a dimensão do público desenvolve-se como um meio discursivo de articulação de demandas e de solução de problemas, de forma cooperativa e compartilhada; uma esfera da ação social, na qual grupos se organizam, percebem e debatem questões comuns, formulam e experimentam soluções, articulam interesses e opiniões. E demandam, quando necessário, diante da forma como afetados

\footnotetext{
${ }^{196}$ DEWEY, The public and its problems, 1991, p. 15, 16, 39, 64 e 126.

${ }_{197}^{197}$ DEWEY, The public and its problems, 1991, p. 39, 4465 e 137.

${ }^{198}$ DEWEY, The public and its problems, 1991, p. 69 e 70; DEWEY, Reconstruction in philosophy, 2004, p. 118 e 119.
} 
pelos conflitos e problemas experimentados, públicos, uma regulação e mediação por parte da esfera política governamental ${ }^{199}$.

3.2. Do reconhecimento das consequências invasivas e dos problemas de coordenação social, assim como do esforço comum de regulá-los, emerge, a partir do público, a noção de Estado ${ }^{200}$.

A experiência social, suas consequências e problemas trazem o público à existência. Em si, contudo, ele é desorganizado e sem forma. Organiza-se como um Estado somando uma estrutura governamental, com representantes dotados de poderes e funções específicas: "Um público articulado e operando através de representantes oficiais é um estado; não há estado sem um governo, mas também não há nada sem o público"201.

A única definição que Dewey entende possível traçar em relação ao Estado é puramente formal: é a organização do público realizada através de uma estrutura política governamental para a proteção dos interesses compartilhados por seus membros ${ }^{202}$. Faz-se, assim, como uma forma peculiar e secundária de associação, "com uma específica função a realizar e específicos órgãos para operar". E inclui, em seu conceito, dois elementos essenciais: o público e, emergindo dele e em referência a ele, como instrumento para sua organização e regulação, mediação e realização de suas pretensões, interesses e vontades, o aparelho de governo:

Esse público é organizado e tornado efetivo por meio de representantes que como guardiões dos costumes, legisladores, administradores e juízes, etc., cuidam de seus interesses específicos por meio de métodos destinados a regular a ação conjunta dos indivíduos e grupos. Então e nessa medida, a associação adiciona a si a organização política, e algo que pode ser governo vem à tona: o público é um estado político ${ }^{203}$.

De qualquer forma, "o que o público pode ser, o que as autoridades públicas são e quão adequadamente eles realizam suas funções são coisas que temos de ir à história para descobrir". O traço característico do Estado, na esteira do público do qual emerge, é a

199 DEWEY, The public and its problems, p. 12, 15, 16, 39; HONNETH, Democracy as reflexive cooperation, 1998, p. 774.

${ }^{200}$ DEWEY, The public and its problems, 1991, p. 12.

${ }^{201}$ DEWEY, The public and its problems, 1991, p. 67.

202 DEWEY, The public and its problems, 1991, p. 33.

${ }^{203}$ DEWEY, The public and its problems, 1991, p. 27, 28, 35 e 71. 
diversidade local e temporal, mostrando-se absolutamente descabida, como já destacado, a busca metafísica de um padrão universalmente válido d'O Estado ${ }^{204}$.

Dewey identifica, então, como critério para aferir o quão bom é um Estado em particular, "o grau de organização do público que é atingido e grau em que seus representantes são constituídos de modo a efetivar sua função de cuidar dos interesses públicos”. Eis a qualidade que, para o autor, pode ser atualizada experimentalmente, de mais adequado, inteligente, racional e moral, no Estado Democrático ${ }^{205}$.

3.3. Na equivocidade da palavra democracia, Dewey chama atenção a um sentido ampliado, alinhado com sua concepção de público, de governo e de Estado.

Define-a como um ideal social e moral, a ser continuamente experimentado, que se constrói e se reconstrói na referência fundamental à experiência comunitária, precedente necessário da esfera propriamente política da vida social. Confunde-se, deveras, com ela: “democracia (...) é a ideia de vida comunitária em si"206.

É a partir, então, da comunidade e, em seu bojo, da emergência do público, que Dewey concebe a esfera governamental, em torno da qual é engendrado o sentido político da democracia. Nesse seu significado específico, a democracia corresponde a "um modo de governo, uma prática especifica de selecionar agentes públicos e de regular sua conduta como pública". Remete, dessa forma, às instituições e procedimentos referentes à eleição, conduta e responsabilidades dos agentes públicos, destacando-se o sufrágio universal, as eleições periódicas e a regra da maioria ${ }^{207}$.

Tudo isso, de acordo com o sentido instrumental conferido à estrutura governamental: um medium por meio da qual a comunidade e o público, democraticamente organizados, exercem a soberania popular e podem, com o amparo de agentes públicos,

\footnotetext{
${ }^{204}$ DEWEY, The public and its problems, 1991, p. 32, 33, 39, 44 e 65.

${ }^{205}$ DEWEY, The public and its problems, 1991, p. 33.

${ }^{206}$ DEWEY, The public and its problems, 1991, p. 82, 143 e 148.

${ }^{207}$ DEWEY, The public and its problems, 1991, p. 82, 83, 144 e 157.
} 
democraticamente eleitos, regular a experiência social e resolver problemas de coordenação social que dela emergem ${ }^{208}$.

Dentro de tal configuração, as decisões do Estado e o Direito que o rege não são mais do que a aposição de um "selo oficial sobre forças já em operação, conferindo-lhes um canal definido por meio do qual agir". O governo, assim como o público do qual emerge, não tem mãos nem ideias próprias a não ser a dos indivíduos, organizados ou não, orientados ou não racionalmente ao interesse comum, que os compõem ${ }^{209}$.

Assim, ainda que sejam instituídos procedimentos e práticas fundamentais para a vivência democrática, o elemento governamental do Estado Democrático não faz, por si só, a democracia. É ilusório esperar a organização da democracia com base, apenas, em formas, órgãos e métodos político-governamentais. E, desse modo, que os procedimentos democráticos assegurem a responsabilidade dos eleitos em relação aos interesses de um eleitorado, organizado e consciente de si; que o só fato de assumir o cargo político implique um modo de pensar e agir adequado, no interesse público, por parte do representante eleito ${ }^{210}$.

A referência ao momento anterior da vida comunitária faz com que, em Dewey, o elemento mais significativo da fase política da democracia e, nela, dos procedimentos político-eleitorais seja o fato de que a "contagem de cabeças" remete e compele aos recursos racionais prévios do debate de ideias, da consulta e da persuasão. Em suma, a regra de maioria "nunca é meramente regra da maioria", constituindo dado fundamental os meios, discursivos e racionais, por meio dos quais a maioria se torna maioria ${ }^{211}$.

Mesmo a forma democrática mais rudimentar já experimentada, com os procedimentos do voto popular, da regra da maioria, etc., induz, em alguma medida, e com imenso potencial educativo, o envolvimento da população; força a consulta, a discussão e o reconhecimento das necessidades e problemas sociais, do interesse comum. Aqui, reside para Dewey, o principal fator qualitativo em seu favor ${ }^{212}$.

208 DEWEY, The public and its problems, 1991, p. 71, 82 e 143. HONNETH, Democracy as reflexive cooperation, 1998, p. 744 e 775.

${ }^{209}$ DEWEY, The public and its problems, 1991, p. 68 e 82.

${ }^{210}$ DEWEY, The public and its problems, 1991, p. 68, 82 e 146.

${ }^{211}$ DEWEY, The public and its problems, 1991, p. 207.

${ }^{212}$ DEWEY, The public and its problems, 1991, p. 181, 206 e 207. 
Enfim, no âmbito da filosofia política deweyana, "o governo existe para servir sua comunidade". A estrutura e os procedimentos governamentais justificam-se na extensão em que sejam "de um tipo que façam do interesse público o mais supremo guia e critério da atividade governamental e que possibilitem ao público dar forma e manifestar seus propósitos de modo ainda mais competente" ${ }^{, 13}$. Daí a atenção, em sua teoria da democracia, ao momento comunitário que antecede as instituições e práticas que compõem a esfera especificamente política da vida democrática.

Dewey apreende a comunidade para além do simples conjunto de ações individualistas, concatenados eventual ou estrategicamente, em vista da satisfação de fins próprios. Identifica-a como uma experiência comunicativa, compartilhada e cooperativa. É impregnada de conteúdo moral, no sentido de que é "emocionalmente, intelectualmente e conscientemente sustentada", na direção de melhores experiências sociais ${ }^{214}$.

Remete a um universo de linguagem, em que, na comunicação, os membros do grupo são formados dentro de uma tradição cultural e, nela inseridos, participam cooperativamente das interações sociais, contribuindo com a organização social, na medida de suas aptidões e possibilidades. A linguagem induz uma perspectiva existencial participante, na qual o sujeito, em sua particularidade essencial, abre-se ao outro como parceiro de comunicação que compartilha o sentido do que foi falado. Ao se comunicar, o sujeito "coloca-se a si próprio do ponto de vista de uma situação na qual (pelo menos) duas partes coparticipam. Essa é a peculiaridade essencial da linguagem"215.

Sob esse enfoque moral e comunicativo, da perspectiva do indivíduo, a experiência comunitária consiste "em ter uma participação responsável de acordo com a capacidade de organizar e dirigir as atividades dos grupos aos quais pertence e de participar, de acordo com a necessidade, dos valores sustentados pelos grupos". Do ponto de vista do grupo, "exige liberação das potencialidades dos membros do grupo em harmonia com interesses e bens que são comuns”. Dessa maneira,

Onde quer que haja atividade conjunta cujas consequências sejam apreciadas como boas por todos os indivíduos que tomam parte nelas, e onde a realização do bem é tal para causar um desejo e um esforço

\footnotetext{
${ }^{213}$ DEWEY, The public and its problems, 1991, p. 146.

${ }^{214}$ DEWEY, The public and its problems, 1991, p. 151.

${ }^{215}$ DEWEY, Experiência e natureza, 1980, p. 36, 40 e 51.
} 
vigoroso em mantê-lo justamente porque se trata de um bem compartilhado por todos, há nessa medida uma comunidade ${ }^{216}$.

Nesse sentido, a vida social "pré-política" e seu valor moral ancoram-se, em Dewey, conforme leitura precisa de Axel Honneth, na experiência da justa divisão social do trabalho. A ela é conferida a força de dar a cada indivíduo a consciência da cooperação social, para a realização de fins comuns: "Somente uma forma de divisão do trabalho que conceda a cada membro da sociedade, de acordo com as habilidades e talentos autonomamente descobertos, uma justa chance de assumir ocupações socialmente desejáveis permite que a consciência da cooperação surja"217.

Conclui, assim, que, no modelo deweyano, a vida democrática aparece como decorrência dessa experiência dos membros do grupo social ao se relacionar uns com os outros cooperativamente. É essa experiência de participação, por meio de uma contribuição individual, única, nas tarefas do grupo, que possibilita ao indivíduo compreender a importância de um público democrático ${ }^{218}$.

Sendo assim, na vida comunitária, o "nós" emerge e se constitui tão inevitavelmente quanto o "eu"; sem que o indivíduo, portanto, coloque-se em oposição ao social. Afinal, não se trata, absolutamente, de um "indivíduo per se, um indivíduo fixo, em isolamento e estabelecido por si mesmo", mas que, como visto, forma-se na associação e na comunicação, compartilhando valores, interesses e desenvolvendo um papel social. $\mathrm{O}$ "eu" e o "meu", em suma, na comunidade, vêm à cena e adquirem sentido em relação íntima com o "nós" e o "nosso"; na extensão, pois, em que a atividade combinada se torna objeto de interesse, vontade e esforço comum e "uma participação particular na ação mútua é conscientemente afirmada ou reivindicada" ${ }^{219}$.

O discurso, compreendido como ação comunicativa, manifesta, dessa maneira, além de seu imenso potencial instrumental de um "meio de ação organizada para um fim" linguístico - destacando-se o potencial de aprendizagem e de construção cooperativa da verdade -, todo seu sentido moral consumatório. Encontra em si mesmo as recompensas de suas possíveis consequências: "Pois não há modo de ação tão satisfatório, nem tão

\footnotetext{
${ }^{216}$ DEWEY, The public and its problems, 1991, p. 147 e 149 e 152.

${ }^{217}$ HONNETH, Democracy as reflexive cooperation, 1998, p. 777.

${ }^{218}$ HONNETH, Democracy as reflexive cooperation, 1998, p. 776 e 780.

${ }^{219}$ DEWEY, The public and its problems, 1991, p. 151 e 152.
} 
recompensador, quanto o consenso organizado da ação". Traz consigo o "sentido de repartir",220.

É sob essa perspectiva comunicativa, a partir de e, num processo de crescimento cognitivo e moral, para além das tradições, instituições e valores socialmente transmitidos e assimilados, que o $e u$, contraposto ao me tradicional, é colocado em proeminência como o fator fundamental na reconstrução inteligente da experiência social. Afinal, é o "detentor do pensamento criativo, o autor da ação e de sua aplicação (...) A mente individual é importante porque somente ela é o órgão de modificações nas tradições e instituições, o veículo de criação instrumental"221.

E, assim, no bojo da tradição da modernidade, os ideais iluministas, expressos no lema da Revolução Francesa, perdem qualquer referência solipisista e metafísica, assumindo um enriquecido conteúdo ativo e comunicativo.

Em conexão com a experiência comunitária, a fraternidade é relacionada aos bens morais, instituições e valores estimados pelo grupo social e que, advindos da associação, dão a direção e significado à conduta de cada um ${ }^{222}$.

Quanto à igualdade, não quer dizer "um tipo de equivalência física ou matemática em virtude da qual qualquer elemento pode ser substituído por outro". Fruto da comunidade, significa a "efetiva consideração pelo que quer que seja distintivo e único em cada um, independentemente de desigualdades físicas e psicológicas". Denota a participação sem entraves e de acordo com a necessidade e a capacidade de cada um, na interação social e nas consequências e resultados da ação associada ${ }^{223}$.

Finalmente, a liberdade. Superando o sentido individualista negativo - a mera retirada de entraves físicos que se impõem ao indivíduo - remete à liberação e atualização, inteligente e plena, das potencialidades individuais na associação, na comunicação. É liberdade comunicativa, de ação comunicativa. Tem "lugar apenas em rica e múltipla associação com os outros", fazendo-se como "poder de ser um eu individualizado fazendo uma contribuição peculiar e usufruindo de seu modo, os frutos da associação"224.

\footnotetext{
${ }^{220}$ DEWEY, Experiência e natureza, 1980, p. 39.

${ }^{221}$ DEWEY, O desenvolvimento do pragmatismo americano, 2007, p. 241 e 242.

${ }^{222}$ DEWEY, The public and its problems, 1991, p. 151.

${ }^{223}$ DEWEY, The public and its problems, 1991, p. 150 e 151.

${ }^{224}$ DEWEY, The public and its problems, 1991, p. 150.
} 
Enfim, como destaca Dewey, nenhum indivíduo "jamais foi emancipado meramente sendo deixado sozinho. A remoção das limitações físicas é apenas uma condição negativa; liberdade positiva não é um estado, mas uma ação", que envolve, necessariamente, comunicação, razão e, desse modo, orientada ao crescimento geral, responsabilidade ${ }^{225}$.

Aos laços comunitários e cooperativos, somam-se, ainda, na ambiência democrática, dois fatores indissociáveis, em vista da consolidação de seu valor racional, cognitivo e moral, na solução dos problemas comuns experimentados socialmente. São eles: o hábito reflexivo de pensar, agir e conviver, marcado pela atitude científica, por parte dos cidadãos, aptos e propensos ao enfrentamento dos problemas de coordenação social; e o ambiente de livre comunicação, que possibilite a expansão, a correção e o compartilhamento do saber produzido e, valendo-se dele, a melhoria permanente das experiências comunitárias $^{226}$.

A filosofia social habermasiana, apoiando-se na teoria do discurso, tratará da matéria, de modo semelhante, em termos de uma situação ideal de fala e da competência (e disposição) comunicativa dos atores (falantes e ouvintes) ${ }^{227}$.

Com isso, Dewey não está propondo, absolutamente, o que negaria a própria concepção de democracia, um governo tecnocrata, por especialistas, desconectado do público, de suas necessidades e do interesse comum. Tampouco está sugerindo - o que, para ele, seria um absurdo -, que todos os membros da comunidade sejam cientistas, restrita a ciência ao ponto de vista conteudista, de um corpo de conclusões ${ }^{228}$.

O que propõe é a assimilação na forma de vida democrática e na conduta do cidadão do hábito reflexivo de pensar e agir e da disposição investigativa, experimental, metodológica, crítica, falibilista, que caracterizam a atitude científica. Pois é esse hábito que, para o autor, possibilita a superação dos equívocos produzidos pelas tradições

${ }^{225}$ DEWEY, The public and its problems, 1991, p. 168; DEWEY, Ethics, 2008, p. 305.

${ }^{226}$ DEWEY, The public and its problems, 1991, p. 184.

${ }^{227}$ FREITAG, Bárbara. A questão da moralidade: da razão prática de Kant à ética discursiva de Habermas. Tempo social. Revista de Sociologia da USP. Volume 01, no 02, São Paulo, 2o semestre de 1989, p. 37; HABERMAS, Jürgen. Direito e democracia: entre factibilidade e validade. Volume 01. Trad. Flávio Beno Siebeneichler. Rio de Janeiro: Tempo Brasileiro, 2012, p. 156; HABERMAS, Jürgen. Teoria do agir comunicativo. Racionalidade da ação e racionalização social. Tomo 01. Trad. Paulo Astor Soethe. Revisão Técnica Flávio Beno Siebeneichler. São Paulo: Editora WMF Martins Fontes, 2012, p. 60 e 61.

${ }^{228}$ DEWEY, Freedom and culture, 1989, p. 114; DEWEY, The public and its problems, 1991, p. 206 e 208. 
irrefletidamente assimiladas, dos preconceitos e medos pessoais e de classe e, ainda, dos enganos decorrentes da propaganda e da difusão de informações em favor de grupos de interesses. Aparece como a "única garantia da possibilidade de uma opinião pública inteligente o suficiente para equacionar os problemas sociais presentes"229.

Atualizada em comunicação, no discurso, permite, então, a assimilação, na prática social, da perspectiva metodológica pragmatista de pesquisa cooperativa da verdade, pela "comunidade de pesquisadores", "com o propósito de lidar com problemas reais enfrentados no curso da ação". Aliam-se o método científico e o democrático ${ }^{230}$.

Isso induz, portanto, como também se verá em Habermas, uma concepção ativa e racional-dicursiva da cidadania, em que o sujeito, fazendo uso de sua liberdade comunicativa, envolve-se, no ambiente público, no processo de reconhecimento das consequências e dificuldades que emergem da interação social; colabora com a formação e com a identificação do público; e, nele, participa da investigação, do debate, da construção, da proposição e da experimentação de soluções racionais, adequadas aos problemas e conflitos sociais e morais bem como de possibilidades experienciais de convivência e organização estatal $^{231}$.

Ao mesmo tempo, implica a consolidação do ambiente público comunicativo, que antecede e ao qual se vincula instrumentalmente a estrutura político-governamental. Tratase de um momento intermediário entre a experiência do problema de coordenação social e sua solução institucionalizada pelo Estado. E se constitui como espaço de reconhecimento e afirmação, como públicos, de pretensões e interesses compartilhados; de articulação de demandas perante o público e o governo; de difusão, discussão, experimentação, correção do conhecimento produzido socialmente e orientado ao tratamento de questões públicas; e de formação racional da opinião pública, compreendida como o julgamento "formado e nutrido por aqueles que constituem o público e se refere a questões públicas"232.

Nesse ponto, Dewey destaca a atuação do cientista. E isso não num sentido tecnocrático, como o governante ideal, qualificado à formulação e determinação das políticas estatais, mas, fundamentalmente, como cidadão que participa do público e da

\footnotetext{
${ }^{229}$ DEWEY, Freedom and culture, 1989, p. 101, 113 e 114.

${ }^{230}$ DEWEY, Freedom and culture, 1989, p. 81; BERNSTEIN, The resurgence of pragmatism, 1992, p. 814 e 815; JOAS, Pragmatism and Social Theory, 1993, p. 19; HONNETH, Democracy as reflexive cooperation, 1998 , p. 772 e 773.

${ }^{231}$ DEWEY, The public and its problems, 1991, p. 45, 126 e 193.

${ }^{232}$ DEWEY, The public and its problems, 1991, p. 177.
} 
pesquisa social, "descobrindo e fazendo conhecidos os fatos dos quais tais políticas dependem". Mais, que faz incorporar, no debate e na opinião pública, as contribuições técnicas e científicas, elevando, então, “o nível em que a inteligência de todos opera”, sem exigir, para tanto, como já destacado, que todos os cidadãos tornem-se cientistas $^{233}$.

Desse modo, a postura ativa dos cidadãos - articulados no público e participando, sem constrangimentos e com iguais direitos, do ambiente comunicativo de debate público de questões sociais e morais - aumenta as chances de respostas adequadas e inteligentes, e assim, de uma contínua melhoria e reconstrução positiva das experiências, do ponto de vista do grupo social que nela toma parte ${ }^{234}$.

A democracia aparece como "condição para o aumento da racionalidade das soluções dos problemas sociais" 235 , na medida em que remete à maior e melhor participação possível de pessoas, no enfrentamento das temas comuns, públicos. Tudo isso, num compartilhar por meio do qual "os significados são ampliados, aprofundados e consolidados no sentido da participação"236. Enfim, "Porque a racionalidade das soluções de cada problema aumenta na medida em que todos os afetados são igualmente incluídos na 'processo de pesquisa', é fora de questão para Dewey que a autodireção política da sociedade tem de ser democraticamente organizada" 237 .

De qualquer forma, a constituição da vida comunitária; a emergência e organização de um público; o debate, proposição e experimentação, no ambiente comunicativo, de soluções aos problemas comuns; a coordenação social possibilitada com a estrutura governamental; em resumo, a experiência ampliada da democracia apresenta-se como um processo gradual, complexo, conflituoso e contingencial.

Na perspectiva deweyana, sempre atenta aos prejuízos de um raciocínio por meio de opostos extremos, a experiência democrática não se restringe, de um lado, a um aglomerado desintegrado de indivíduos cuja incongruência de propósitos é tão grande que não permite mais do que uma maioria aferida aritmeticamente. De outro, não se efetiva,

\footnotetext{
${ }^{233}$ DEWEY, The public and its problems, 1991, p. 207 e 210.

${ }^{234}$ HONNETH, Democracy as reflexive cooperation, 1998, p. 772 e 773.

${ }^{235}$ HONNETH, Democracy as reflexive cooperation, 1998, p. 775.

${ }^{236}$ DEWEY, Experiência e natureza, 1980, p. 51.

${ }^{237}$ HONNETH, Democracy as reflexive cooperation, 1998, p. 775.
} 
absolutamente, como uma autoadministração orgânica, direta e naturalmente resultante dos vínculos cooperativos da comunidade ${ }^{238}$.

Os elementos da experiência democrática - hábitos democráticos de pensar, agir e conviver, vida comunitária, espaço público comunicativo, público, governo democrático pressupõem, favorecem e fortalecem um ao outro, num continuum experiencial positivo. Mas isso de nenhuma forma necessária.

Pressupõem, para sua efetivação, uma disposição, uma atitude da personalidade que, contudo, não é inata. Não é um traço da natureza humana, como também não é seu oposto. Sua formação e aprendizagem somente podem ocorrer dentro da própria experiência social democrática ${ }^{239}$.

Envolve, ademais, a apreensão e experiência do Estado como um problema prático extremamente complexo, que, afinal,

Demanda capacidade de observar e reconhecer as consequências do comportamento dos indivíduos unidos em grupos e de delineá-las em sua fonte e origem. Envolve a seleção de pessoas para atuar como representantes dos interesses formados a partir dessas consequências observadas e para definir as funções que eles devem ter e empregar. Requer a instituição de um governo de tal modo que os detentores da reputação e do poder que caminham junto com o exercício daquelas funções empreguem-nos para o público e não os desviem ao seu benefício privado $^{240}$.

Remete, ainda, à constituição, o reconhecimento e a organização dos membros da sociedade civil num público, num cenário desfavorável. Nele, conforme o diagnóstico de modernidade apresentado por Dewey, não caminhou, ao lado do progresso material, científico e tecnológico, o correspondente desenvolvimento das experiências humanas, em termos sociais e morais. Em verdade, implicou uma ambiência social em rápida transformação, instável, marcada pelo individualismo, pela lógica da concorrência em detrimento da cooperação, pela desagregação social, na qual emergem novos e mais tormentosos problemas e conflitos com os quais a humanidade ainda não se mostrou capaz de $\operatorname{lidar}^{241}$.

Nesse contexto social, o público está enfraquecido, disperso e desorientado, vive um eclipse. Tem dificuldade de, reconhecendo-se e organizando-se como público

\footnotetext{
${ }^{238}$ HONNETH, Democracy as reflexive cooperation, 1998, p. 767 e 774.

${ }^{239}$ DEWEY, Freedom and culture, 1988, p. 88.

${ }^{240}$ DEWEY, The public and its problems, 1991, p. 32, 33 e 177.

${ }^{241}$ DEWEY, The public and its problems, 1991, p. 126, 140, 141 e 75.
} 
democrático, perceber criticamente os resultados negativos e positivos das interações sociais e de empregar métodos inteligentes na detecção e diagnóstico dos problemas sociais e na formulação e execução de políticas para lidar com eles ${ }^{242}$.

Recusando, todavia, qualquer metahistória que determine a emancipação da humanidade, Dewey vislumbra-a, conforme exposto, na ambiência democrática. E reconhecendo os descaminhos que a afetaram historicamente, identifica, ainda assim, a experiência democrática como único percurso para o aperfeiçoamento da democracia, na direção da realização de seu potencial discursivo, moral e cognitivo, expresso na melhoria contínua das experiências individuais e coletivas. Um percurso experiencial, mais uma vez, conflituoso, complexo, processual e contingencial.

É a experiência contínua e renovada da democracia, com todas as suas imperfeições, que pode proporcionar aos cidadãos a aprendizagem de suas práticas, hábitos e atitudes. Dela decorre o fortalecimento, em termos de qualidade racional, do público e dos espaços comunicativos, com o "aperfeiçoamento dos métodos e das condições de debate, discussão e persuasão", bem como o funcionamento do aparelho governamental, de forma comprometida com as demandas e com o interesse social ${ }^{243}$.

Eis o sentido em que, para Dewey, deve ser apreendida a concepção de que a cura para os males da democracia é mais democracia: a reconstrução de sua experiência, a expansão, melhoria e aprofundamento de suas instituições, procedimentos e práticas racionais, comunitárias, comunicativas e cooperativas, na continuidade de sua experiência e aprendizagem ${ }^{244}$.

\section{O modelo deweyano de educação}

No âmbito da experiência da democracia e combinada com sua consolidação e fortalecimento contínuo, como ambiência da emancipação, tem lugar a proposta deweyana de educação progressiva.

Dewey a enraíza na ideia de experiência, assumindo-a como "os meios e as metas da educação”. Define, nesse sentido, seu pensamento pedagógico - parafraseando Lincoln

\footnotetext{
242 DEWEY, The public and its problems, 1991, p. 77, 126 e 146; DEWEY, Reconstruction in philosophy, 2004, p. 97 e 98.

${ }^{243}$ DEWEY, The public and its problems, 1991, p. 82, 168, 169 e 208.

${ }^{244}$ DEWEY, The public and its problems, 1991, p. 144.
} 
ao falar da relação entre o governo democrático e o povo - como "uma filosofia da educação de, por e para a experiência"245.

Não se trata, evidentemente, de qualquer experiência, mas sim aquela com a qualidade para promover a educação, a experiência educativa. O reconhecimento, pelo autor, de que a vida, a experiência e a aprendizagem não se separam ${ }^{246}$ e, dessa forma, de que toda educação verdadeira é fruto da experiência, "não significa que todas as experiências são verdadeiramente ou igualmente educativas. Experiência e educação não são diretamente equivalentes uma a outra. Algumas experiências são deseducativas"247 .

4.1. É no contexto norte-americano da primeira metade do século XX, que Dewey apresenta sua concepção pedagógica progressiva, mais humana e democrática. Visa à superação do que denomina o método tradicional: perspectiva que, a seu ver, não proporciona experiências educativas, favorecendo, mesmo, "experiências erradas", "deseducativas", e se colocando, concomitantemente, na contramão do projeto democrático. Apesar disso, completa o autor, conspira a seu favor "a tendência de pais e escolas autoritárias em demandar rápidas e tangíveis evidências de progresso", ainda que ao custo da "dependência de pura memorização e rotina mecânica"248.

A perspectiva tradicional, na definição deweyana, reduz o processo pedagógico à transmissão unilateral e impositiva, "de cima para baixo e de fora para dentro", de uma tradição cultural ao educando ${ }^{249}$.

Corresponde o ensino do passado, tendo em vista "preparar o jovem para suas responsabilidades futuras e para o sucesso na vida, por meio da aquisição de um conjunto organizado de informações e de formas preestabelecidas de habilidades que constituem o material de instrução":

Aprender aqui significa adquirir o que já está incorporado aos livros e às cabeças das gerações anteriores. (...) É ensinado como um produto acabado, sem maior atenção quanto aos modos como tal produto foi originalmente construído ou quanto às mudanças que certamente ocorrerão no futuro. Trata-se de um produto cultural de sociedades que consideram que o futuro será exatamente como o passado, e que passa a

\footnotetext{
${ }^{245}$ DEWEY, Experiência e educação, 2010, p. 30 e 93.

246 TEIXEIRA, A pedagogia de Dewey, 1980, p. 115.

${ }^{247}$ DEWEY, Experiência e educação, 2010, p. 26 e 27.

${ }^{248}$ DEWEY, How we think, 1997, p. 54 e 61.

${ }^{249}$ DEWEY, Experiência e educação, 2010, p. 19 e 21.
} 
ser usado como substância educacional em uma sociedade em que a mudança é uma regra e não uma exceção ${ }^{250}$.

Parte, assim, de um conjunto de informações, habilidades e regras de conduta que se encontra fora da experiência de vida do educando, mas que, da perspectiva do educador, do "especialista", ser-lhe-á útil, em algum momento no futuro. E se constrói sobre o equívoco conceitual de que transmitindo tal conteúdo, ao qual é atribuído um valor educacional em si, marcadamente dogmático, os educandos estariam preparados para as necessidades e circunstâncias do futuro ${ }^{251}$.

Ignora, com isso, um dos lados da relação educacional: o educando e suas experiências. É desligada das perplexidades por ele vivenciadas e, desse modo, do exercício do pensar reflexivo para sua solução, usando os recursos cognitivos de que dispõe. Apelando a um despropositado pensar de modo genérico, sem referência à existência, na experiência do educando, de alguma dificuldade que o perturbe, supõe que "a informação acumulada separada do uso no reconhecimento e na solução de problemas pode, mais tarde, ser livremente empregada, à vontade, pelo pensamento" 252 .

Configura-se, dessa forma, na distância entre as experiências, os problemas e os recursos cognitivos da criança, de um lado, e, de outro, os conteúdos ensinados e os resultados esperados "além do alcance da experiência" que ela já possui. E assim a pedagogia tradicional tem que ser impositiva. Não há alternativa, "mesmo que bons professores usem artifícios para mascarar tal imposição, a fim de minimizar seus aspectos obviamente brutais" 253 .

O ensino se consolida como uma "dieta de matérias pré-digeridas", em que cabe ao aluno tomar as "doses conforme prescritas" 254 , crítica que aparece, mais tarde, em Paulo Freire - em quem a obra deweyana ecoou, sobretudo por meio dos trabalhos de Anísio Teixeira ${ }^{255}$-, sob a denominação "educação bancária”: a educação desvirtuada em "ato de

${ }^{250}$ DEWEY, Experiência e educação, 2010, p. 20 e 21.

${ }^{251}$ DEWEY, Reconstruction in philosophy, 2004, p. 106; DEWEY, Experiência e educação, 2010, p. 20, 47, 49 e 79.

${ }^{252}$ DEWEY, How we think, 1997, p. 12 e 53.

${ }^{253}$ DEWEY, Experiência e educação, 2010, p. 21.

${ }^{254}$ DEWEY, Experiência e educação, 2010, p. 47 e 48.

${ }^{255}$ GHIRALDELLI JUNIOR, Filosofia e história da educação brasileira, 2003, p. 118; MURARO, Darcísio Natal. Relações entre a filosofia e a educação de John Dewey e a de Paulo Freire. Educação \& Realidade, vol. 38, no 03, jul./set. 2013, p. 813, e 824. Disponível em: http://www.ufrgs.br/edu_realidade. Acesso em $24 / 06 / 2014$. 
depositar, de transferir, de transmitir valores e conhecimentos", de modo que "não se verifica nem pode verificar-se superação" 256 .

Na estrutura tradicional, "a atitude dos alunos deve ser, no geral, de docilidade, receptividade e obediência”. Premia-se a passividade, valorizando o silêncio como uma das virtudes educacionais mais importantes. O educando habitua-se a receber, aceitar e memorizar as ideias alheias, as fórmulas prescritas, e recitá-las de forma correta. Tudo isso sem investigação pessoal nem teste de seu valor. Utiliza o pensamento "para descobrir o que os outros acreditam e, então, para. As ideias dos outros, como encarnadas na linguagem, tornam-se o substituto para as próprias ideias". A "aprendizagem" reduz "o indivíduo a uma vida parasita em experiências de segunda mão"257.

Enfatizando hábitos de quietude, aceitação, subserviência e dogmatismo, nega ao educando a oportunidade de se habilitar e dispor-se, progressivamente, a contrapor, perceber, estranhar, questionar, recriar sua experiência, conferindo-lhe significado; a ampliar as possibilidades experienciais; a dirigir e coordenar sua ação, participando da experiência social; tudo isso na extensão de suas capacidades, habilidades, instrumentos cognitivos e experiências pessoais, em permanente expansão e reorganização.

Em oposição à experiência do diálogo, reduz a comunicação ao seu aspecto de imposição e unilateralidade. Despreza - em favor da resposta predita - tanto a pesquisa dialógica para a construção cooperativa de respostas aos problemas comuns e do significado da experiência, como o experimento de seu valor.

Por tudo isso, a pedagogia tradicional efetiva-se de forma antidemocrática do princípio ao fim. Não habilita nem habitua à democracia. Ensinar o que é democracia, definindo o termo, especificando seus elementos e instrumentos não pode ir além do plano abstrato de uma teoria não praticada. Renunciando à práxis democrática, não permite que o educando apreenda seu sentido, mais profundo, não vivido. $O$ cidadão formado para a passividade e aceitação de soluções prontas a problemas nem sequer colocados, dificilmente pode adquirir a competência e formar o hábito de, em sua vida social, diante dos problemas de coordenação da ação, engajar-se num público, participando ativamente do discurso em vista de sua solução compartilhada.

${ }^{256}$ FREIRE. Paulo. Pedagogia do oprimido. 50 - ed. Rio de Janeiro: Paz e Terra, 2011, p. 82.
${ }^{257}$ DEWEY, How we think, 1997, p. 177; DEWEY, Experiência e educação, 2010, p. 65. 
4.2. A oposição à rigidez, ao caráter impositivo, antidemocrático da pedagogia tradicional não conduz Dewey, absolutamente, a se restringir a uma formulação antitética, no extremo oposto, orientada, apenas, a partir do que é rejeitado. Afinal, "Os problemas não são sequer identificados, quanto mais solucionados, quando se supõe que basta rejeitar as ideias e as práticas da velha educação e partir para uma posição extremamente oposta". E exemplifica:

Quando a autoridade externa é rejeitada, não significa que toda autoridade deva ser rejeitada, mas sim que é necessário buscar uma forma mais efetiva de autoridade. $\mathrm{O}$ fato de que a educação tradicional impunha aos mais jovens os conhecimentos, os métodos e as regras de conduta dos adultos não significa, a não ser com base na filosofia dos extremos, de "isto ou aquilo", que o conhecimento e as habilidades dos adultos não tenham valor diretivo para as experiências dos mais novos ${ }^{258}$.

Atentando-se ao desenvolvimento construtivo e positivo de sua perspectiva filosófica, a proposta educacional progressiva deweyana não implica uma concepção nãodiretivista, conforme a acusação contra ele disparada.

Sua filosofia educacional enraíza-se, como antecipado, na experiência educativa. E por educação, Dewey entende o processo contínuo de crescimento intelectual e moral da pessoa. Define-a como o processo comunicativo de constante reorganização da experiência, por meio do qual o sujeito, adquirindo experiências e reconstruindo permanentemente seus recursos cognitivos, amplia e aprofunda o significado de sua experiência e desenvolve a habilidade e o hábito de um sempre melhor controle e direção do curso das experiências subsequentes ${ }^{259}$.

O crescimento contínuo do educando, com cada vez mais autonomia cognitiva e moral, constitui o fator que define, em Dewey, a qualidade educativa da experiência. Estabelece, então, a "direção positiva para a seleção e organização de conteúdos e métodos educacionais apropriados",260.

De acordo com sua perspectiva moral do crescimento como fim, é educativa a experiência que habilita e dispõe o educando a continuar sua educação, continuar crescendo; promove sua capacidade de desenvolvimento constante. Tudo isso, em comunicação, valendo-se do potencial de aprendizagem e o sentido instrumental (cognitivo) e consumatório do discurso. No âmbito da sociedade democrática e em vista à

\footnotetext{
${ }^{258}$ DEWEY, Experiência e educação, 2010, p. 22 a 24.

${ }^{259}$ DEWEY, Democracy and education, 1916, p. 63, 89 e 90.

${ }^{260}$ DEWEY, Experiência e educação, 2010, p. 28, 31 e 93.
} 
sua promoção, implica, necessariamente, um crescimento em geral, que inclui o outro, de modo a projetar uma continuidade e uma reconstrução das experiências do grupo social, como um todo, numa direção positiva ${ }^{261}$.

A experiência educativa envolve, para isso, em primeiro lugar, o desenvolvimento do pensar, agir e conviver reflexivos, com a atitude científica.

Como hábito formado na experiência, o pensar - e o correlato agir e interagir -, nesse seu melhor sentido, não surge naturalmente, de modo espontâneo. E mais, o ambiente social, por si só, não é suficiente para sua aquisição. Na verdade, prejudica-o, muitas vezes, ao promover "hábitos equivocados de pensar", marcados pela assimilação acrítica de valores, instituições e ideias que compõem a tradição cultural. Sendo assim,

Uma vez que tais hábitos não são presentes da natureza (não importa o quão forte é a aptidão para adquiri-los); uma vez que, ademais, as circunstâncias casuais do ambiente natural e social não são suficientes para compelir sua aquisição, o principal ofício da educação é fornecer condições que trabalhem para sua aquisição. A formação desses hábitos é a educação da mente ${ }^{262}$.

A educação progressiva deweyana, dessa forma, opondo-se à redução do processo educativo ao depósito infinito de informações na mente do educando, centra sua atenção e se organiza em função e em vista da formação de "bons hábitos de pensar"263.

Considerando, então, que o passo inicial, o estímulo para o pensar consiste num genuíno problema que emerge da experiência do sujeito, causando-lhe perplexidade, a relação estabelecida entre educação e o exercício do pensar remete, desde logo, em Dewey, a dois princípios básicos de organização da experiência educativa.

Primeiro, a derivação dos conteúdos educacionais das experiências comuns de vida. A educação deve estar íntima e necessariamente relacionada às experiências de vida do educando. Deve partir delas. Como Dewey destaca, "essas experiências e as capacidades desenvolvidas a partir delas fornecem o ponto de partida para todo aprendizado futuro". Assim, "Tudo o que possa ser considerado como matéria de estudo,

${ }^{261}$ DEWEY, Experiência e educação, 2010, p. 36 e 37; DEWEY, Democracy and education, 1916, p. 63, 89, 90 e 117.

${ }^{262}$ DEWEY, How we think, 1997, p. 25, 28, 43 e 44.

${ }^{263}$ DEWEY, Democracy and education, 1916, p. 192. 
seja aritmética, história, geografia ou qualquer uma das ciências naturais, deve derivar de materiais que, originalmente, pertençam ao escopo da experiência comum cotidiana" ${ }^{264}$.

Segundo, a educação baseada na solução de problemas, extraídos das mencionadas experiências, a serem vencidos por meio do exercício do pensamento em desenvolvimento. São inúteis, absolutamente infrutíferos, para Dewey, os "apelos genéricos à criança (ou ao adulto) para pensar", sem a consideração de alguma dificuldade que o incomode. O pensar parte de perplexidades, que causam um estado de hesitação ao educando. E, para tanto, devem ser problemas seus, dificuldades que surjam de sua experiência ${ }^{265}$.

Somente assim, a experiência educativa pode dispor e capacitar o educando aos passos subsequentes que compõem o pensar. Permite-lhe, progressivamente, a partir de sua experiência, o cultivo de hábitos reflexivos: a apreensão sempre mais adequada de sua experiência; a inferência de respostas, cada vez mais profundas e coerentes ao problema colocado; o raciocínio amparado em conclusões testadas e fundamentadas, distinguindo-as das meras opiniões; e, finalmente, fechando o percurso do pensamento, na versão pragmatista deweyana, a aplicação das respostas, testando-as, para "fazer seu sentido claro e descobrir por si mesmo sua validade" 266 .

Como já destacado, a autonomia é referida, por Dewey, à aprendizagem e prática do pensar reflexivo. Remete à liberdade da mente. E esta, por sua vez, implica o autocontrole ou, ainda, a disciplina do pensar, pela educação:

Na medida em que a mente é disciplinada, o controle do método em dada matéria é alcançado, de modo que a mente é capaz de se orientar independentemente, sem tutela externa. O objetivo da educação é precisamente desenvolver a inteligência dessa categoria independente e efetiva - a mente disciplinada. Disciplina é positiva e construtiva ${ }^{267}$.

A disciplina da mente, organizando o pensar e permitindo seu exercício inteligente, é vista, enfim, como fator libertador: disciplina, em termos intelectuais, é compreendida como sinônimo de liberdade. A liberdade da inteligência disciplinada constitui a liberdade emancipadora do agir irrefletido, tanto o rotineiro, conformado à tradição cultural, como o impulsivo, determinado por forças libidinais descontroladas ${ }^{268}$.

\footnotetext{
${ }^{264}$ DEWEY, Experiência e educação, 2010, p. 22, 75 e 77.

${ }^{265}$ DEWEY, How we think, 1997, p. 12.

${ }^{266}$ DEWEY, Democracy and education, 1916, p. 192; DEWEY, How we think, 1997, p. 27 e 28.

${ }^{267}$ DEWEY, How we think, 1997, p. 63; DEWEY, Experiência e educação, 2010, p. 66.

${ }^{268}$ DEWEY, How we think, 1997, p. 64; DEWEY, Experiência e educação, 2010, p. 66 e 67.
} 
A experiência educativa, assim, corresponde à "experiência inteligente em que participa o pensamento". Conforme a maturidade do educando, dispõe-no, habitua-o e capacita-o, progressivamente, de acordo com o seu inventário, cognitivo, moral e experiencial - em permanente reconstrução -, à solução de problemas em sua experiência, apreendendo-a em seu significado, em suas relações e continuidades, de modo sempre mais profundo e enriquecido ${ }^{269}$. Dessa maneira, o sujeito habilita-se, também, a nela atuar, reconstruindo-a objetivamente, de modo mais racional, mais adequado aos propósitos estabelecidos: o "desenvolvimento inteligentemente direcionado de possibilidade inerentes às experiências cotidianas" 270 .

Tudo isso, numa trajetória moral cognitivista que vai da heteronomia à autonomia, exercida de modo cada vez mais pleno e enriquecido. Um percurso processual, gradual, contínuo de crescimento, intelectual e moral, junto com o qual, também paulatinamente, alarga-se e se adensa o universo experiencial do sujeito.

De acordo com esse processo e em vista de sua realização, Dewey afirma um terceiro princípio organizacional da experiência educativa: o desenvolvimento progressivo do conteúdo educacional de acordo com a maturidade do aluno, isto é, "desenvolvimento sistemático voltado para a expansão e organização dos conteúdos das matérias de estudo a partir da ampliação da experiência do aluno"271.

A experiência educativa, propugnada por Dewey, direciona-se, também, sem dúvida, a preparar o educando para a experiência futura; porém não na acepção "terrivelmente distorcida", adotado pela educação tradicional. O "verdadeiro significado de preparação", no âmbito da educação progressiva, significa "ajudar o educando a experimentar tudo aquilo para o que ele já é capaz”, em sua experiência presente, a partir dos instrumentos cognitivos, habilidades que formam sua personalidade. Implica, assim, que "a pessoa, seja jovem ou adulto, extrai para si de sua experiência presente tudo o que nela há no momento em que a vivencia", de modo a ser capaz de fazer o mesmo no futuro. Criticando, enfim, a pedagogia tradicional, conclui:

O ideal de usar o presente simplesmente para se preparar para o futuro contradiz a si mesmo. Tal ideal omite, e até mesmo impede, as próprias condições para que a pessoa possa se preparar para o seu futuro. Sempre vivemos o tempo em que estamos e não algum outro tempo, e só

\footnotetext{
269 TEIXEIRA, A pedagogia de Dewey, 1980, p. 116.

${ }^{270}$ DEWEY, Experiência e educação, 2010, p. 93.

${ }^{271}$ DEWEY, Experiência e educação, 2010, p. 76 e 77.
} 
extraindo de cada tempo o sentido completo de cada experiência presente que estaremos preparados para fazer o mesmo no futuro. Essa é a única preparação que realmente conta ao longo da vida ${ }^{272}$.

Assim, partindo das experiências do educando, apreendidas, significadas e vivenciadas em sua plenitude, conforme o nível de maturidade intelectual e moral, e baseando-se em problemas nelas identificados - a serem solucionados por meio do exercício do pensar -, o processo educacional vai ampliando, reorganizando, enriquecendo e tornando mais complexo o universo experiencial do educando. E, diante dele, apresentam-se novos e mais complexos problemas, agora enfrentados por sujeitos cada vez mais aptos para tanto. Dentro do continuum experiencial positivo:

O conhecimento adquirido em cada experiência entra em conexão com novos objetos e acontecimentos que requerem novas capacidades, ao mesmo tempo em que o exercício dessas capacidades refina e amplia o conteúdo dessas experiências. As dimensões vitais de espaço e tempo são expandidas. O ambiente, ou seja, o mundo da experiência se torna constantemente maior e, supostamente, mais, denso ${ }^{273}$.

Desse modo, as experiências, na medida em que educativas, permanecem vivas, frutífera e criativamente, nas experiências subsequentes, preparando o sujeito para "experiências posteriores de qualidade mais ampla e mais profunda". Propendem o educando a caminhar a lugares não conhecidos "além de seus limites". Estimulam a reflexão, sempre mais acurada e metódica e a busca de novas informações, experimentando-as no preenchimento de lacunas na compreensão experiência, numa espiral contínua em que os "novos fatos e novas ideias, assim obtidos, tornam-se base para novas experiências em que novos problemas se apresentam”. Tornam o educando, por tudo isso, "capaz de mais educação: mais sensível às condições de crescimento e mais capaz de tirar vantagens delas". Para Dewey, eis o "sentido próprio de crescimento, continuidade, reconstrução da experiência" 274 .

No processo contínuo de crescimento intelectual e moral em direção à autonomia, o sujeito qualifica, permanentemente, o olhar que se tem da realidade e se habilita a responder de modo sempre mais coerente e profundo aos problemas, conflitos e desafios

\footnotetext{
272 DEWEY, Experiência e educação, 2010, p. 48, 50 e 51.

${ }^{273}$ DEWEY, Experiência e educação, 2010, p. 76.

${ }^{274}$ DEWEY, Reconstruction in philosophy, 2004, p. 106; DEWEY, Experiência e educação, 2010, p. 29, 38, 48,78 e 82 .
} 
que se lhe apresentam. Pode, então, guiar-se e atuar de modo positivo e inteligente no controle e na reconstrução da experiência ${ }^{275}$.

Tal liberdade de inteligência e autonomia moral, como destacado, são apreendidas, na teoria deweyana, intersubjetivamente. Perfazem-se na comunicação. Para chegar aí, a educação se consolida - e não podia ser de outra forma - como um processo comunicativo. Constrói-se na linguagem, a partir da qual a individualidade é formada e dentro da qual o saber, o significado, a direção e a reconstrução das experiências, individuais e coletivas, podem atingir seu melhor sentido. Aqui, emerge um quarto princípio de organização da experiência educativa: a interação dialógica.

Todo e qualquer processo formativo passa, inevitavelmente, pela comunicação. Afinal, como já destacado, a mente e o exercício do pensamento são reflexos da conversação com os outros ${ }^{276}$. Nessa medida, as qualidades e características do hábito de pensar projetam a forma como se efetivou a experiência comunicativa.

Como Dewey destaca, ao falar da pedagogia tradicional, a comunicação pode se deturpar em imposição e unilateralidade, favorecendo, por conseguinte, a conformação do pensar em hábitos dogmáticos, solipsistas e passivos.

Mas pode, também, fazer-se dialogicamente, na comunicação que rompe a unilateralidade e em que o sujeito em formação, "é libertado de seu isolamento imediato e participa da comunhão de significados”, compartilhados, ampliados e enriquecidos na medida dessa participação ${ }^{277}$.

Desse modo, enriquecida no sentido do diálogo, a experiência educativa implica, em primeiro lugar, incluir o educando, trazendo o contexto histórico, social e cultural em que se insere, suas experiências e suas perplexidades, para o processo formativo ${ }^{278}$. Com isso, na linha dos dois primeiros princípios da experiência educativa supramencionados, movimenta e favorece o cultivo do pensar reflexivo.

E mais. Refletindo a interação dialógica, o educando pode desenvolver o hábito de pensar como prática comunicativa cooperativa, inclusiva do outro. Dessa maneira,

\footnotetext{
${ }^{275}$ DEWEY, Reconstruction in philosophy, 2004, p. 77, 80 e 81.

${ }^{276}$ DEWEY, Experiência e natureza, 1980, p. 31; MEAD, Mind, self and society, 1992, p. 141.

${ }^{277}$ DEWEY, Experiência e natureza, 1980, p. 51.

${ }^{278}$ DEWEY, Experiência e educação, 2010, p. 41.
} 
superando os equívocos da razão solipsista e os particularismos semânticos de seu universo linguístico, a pessoa dispõe-se à participação, no discurso, do compartilhamento, enriquecimento, expansão e correção do saber, beneficiando-se, em seu melhor sentido, dos potenciais instrumental-cognitivo e consumatório da comunicação.

Ao habituar, enfim, a um pensar que remete à construção compartilhada de respostas aos problemas experienciados, a educação progressiva deweyana habilita e dispõe o sujeito a apreender, significar, controlar e vivenciar a experiência, de modo sempre mais enriquecido, em relação com: experiência que, em última análise, ampliada à convivência social e ao discurso para o enfrentamento de conflitos percebidos como públicos, define a democracia.

A referência ao diálogo, cuja participação exige, do sujeito, habilidades e instrumentos cognitivos que somente ao longo do processo educativo são gradualmente desenvolvidos, remete, finalmente, a um último princípio organizativo da experiência educativa deweyana: a função diretiva docente.

O crescimento contínuo e, para tanto, o desenvolvimento de hábitos de pensar reflexivo, para Dewey, já se destacou, não se efetivam de modo mágico e espontâneo. Não emergirão, na criança, natural e inevitavelmente, de atividades totalmente livres, do mero brincar e se divertir, sem qualquer direcionamento ${ }^{279}$.

O crescimento do sujeito se contrasta com a unilateralidade e autoritarismo da educação tradicional, contrasta, também, com o extremo oposto, da ausência de direção, do excesso de indulgência, igualmente prejudiciais. Pois promovem negativamente a continuidade, de modo a isolar a pessoa num baixo nível de crescimento, limitando suas possibilidades experienciais $^{280}$.

Cabe, assim, ao educador - o que inclui o pai, a mãe, o professor, a pessoa mais experiente, em geral - apresentar a direção e o caminho da experiência educativa. E isso, não no sentido da imposição dogmática da verdade e da moral, mas da promoção e favorecimento de experiências educativas.

${ }^{279}$ DEWEY, How we think, 1997, p. 43 e 44.

${ }^{280}$ DEWEY, Experiência e educação, 2010, p. 38. 
Cumpre-lhe, nesse sentido, a tarefa fundamental de regular, em conformidade o estágio de crescimento do educando, as condições objetivas em que a experiência ocorre. É responsável, enfim, pela "determinação do ambiente que, em interação com as necessidades e capacidades de seus alunos, criará uma experiência educativa válida". E isso inclui:

(...) o que é feito e como é feito pelo educador não só as palavras faladas, mas o tom de voz em que são faladas; equipamentos, livros, aparelhos e brinquedos, jogos; materiais com os quais os indivíduos interagem e, acima de tudo, a ampla organização social na qual uma pessoa está envolvida $^{281}$.

Dewey ilustra tal atuação, valendo-se do exemplo do papel "docente" da mãe em relação ao seu bebê:

As necessidades que um bebê tem de comida, descanso e atividades são certamente fundamentais e decisivas em certo aspecto. A criança deve ser alimentada, deve ter condições confortáveis para dormir, etc. Porém, isso não significa que os pais devam alimentá-lo toda vez que estiver nervoso ou irritado, de modo que não se possa estabelecer uma programação de horas regulares para a alimentação, o sono, etc. A mãe inteligente leva em consideração as necessidades da criança, mas não de maneira a dispensar sua própria responsabilidade de regular as condições objetivas com base nas quais as necessidades são satisfeitas ${ }^{282}$.

E, referindo-se especificamente ao ambiente escolar, destaca que o docente, como pessoa com mais experiência, deve atuar não como um ditador, mas como um líder que, como membro de um grupo do qual participa, positiva e ativamente, com "uma responsabilidade especial de conduzir as interações e intercomunicações que constituem a vida do grupo enquanto comunidade". Comparando com a escola tradicional, afirma:

Quando os alunos constituíam uma turma ao invés de um grupo social, o professor atuava, necessariamente, como um agente externo, e não como aquele que direciona os processos de troca em que todos participam. Quando a educação tem como base a experiência e a experiência educativa é vista como sendo um processo social, a situação muda radicalmente. $\mathrm{O}$ professor perde a sua posição de chefe externo ou ditador, para ocupar a posição de líder das atividades do grupo ${ }^{283}$.

É importante mencionar, aqui, que tal atuação docente diretiva não dispensa nem mesmo a transmissão, a exposição de conteúdos. Aliás, em seu momento inicial, a

\footnotetext{
${ }^{281}$ DEWEY, Experiência e educação, 2010, p. 46.

${ }^{282}$ DEWEY, Experiência e educação, 2010, p. 42 e 43.

${ }^{283}$ DEWEY, Experiência e educação, 2010, p. 60.
} 
comunicação, no processo educacional, consiste, basicamente, em transmissão de informações, expectativas e padrões de comportamento ${ }^{284}$.

Trata-se de expediente fundamental para que o educando possa ingressar no universo de linguagem e, assim, na tradição cultural, a partir do que, constituindo sua individualidade, pode, em seu solilóquio, pensar, bem como, na experiência comunicativa, interagir.

A finalidade da prática expositiva, enfim, é fornecer material para a reflexão e investigação, e não "pábulo intelectual pronto, a ser aceito e engolido". Dewey apresenta, nessa linha, recomendações para sua realização: primeiro, deve ser necessária, no sentido de que não deve prejudicar a observação, a experiência e a pesquisa pessoal, possível ao educando, considerando seu nível de maturidade intelectual; segundo, não deve ser dogmática, impositiva de uma verdade inquestionável; terceiro deve ter relação com um problema ligado à experiência pessoal do educando, isto é, o "material fornecido pela comunicação deve inserir-se em algum sistema ou organização da experiência já existente" ${ }^{285}$. Tudo isso de modo inversamente proporcional ao crescimento do educando e da autonomia cognitiva e moral por ele adquirida ao longo de sua educação.

4.3. Para Dewey, a educação que promove o crescimento individual não se distingue, em última análise, da preparação e da vivência, de modo sempre mais pleno, da experiência compartilhada da democracia. Trata-se dos aspectos individual e socialcomunicativo, absolutamente complementares e indissociáveis, da emancipação.

O percurso educativo individual em direção à autonomia aparece como um processo racional de formação de hábitos reflexivos de pensar, agir e conviver, os quais encontram seu melhor sentido cognitivo e moral na interação comunicativa própria à democracia. Nela, então, pode ser atualizado todo o potencial instrumental (cognitivo) e consumatório do discurso ${ }^{286}$.

A formação social do indivíduo cria condições para o exercício solidário da vida em comum, sem prejuízos à individualidade. A experiência educativa possibilita ao sujeito em crescimento, no diálogo e a partir do enfrentamento dos problemas na experiência, a 
apreensão compartilhada de seu significado, de modo sempre mais amplo, denso e enriquecido. E isso, na extensão em que, no curso dessa mesma experiência, alarga e reorganiza seu próprio instrumental experiencial e cognitivo. Dessa forma, o sujeito habilita-se, progressivamente, também, à direção e ação reconstrutiva positiva, em comunicação, de suas experiências, num sentido objetivo. Como sintetiza Mead, o pensamento reflexivo, solucionador de problemas confrontados no curso da experiência, torna-se, enfim, o mecanismo por meio do qual a reconstrução social é efetivada, inteligentemente, pelos membros do grupo social ${ }^{287}$.

"Esparramada" para todos os âmbitos da vida social, a experiência educativa forma o sujeito para o exercício ativo da cidadania, habilitando e dispondo-o ao enfrentamento de conflitos e problemas decorrentes da interação social, fazendo uso de sua liberdade comunicativa e se engajando no discurso público para sua solução cooperativa. A experiência educativa, assim espraiada, confunde-se com a experiência democrática.

Mas tudo isso não pode se efetivar senão numa ambiência que favoreça, ou pelo menos admita, a experiência social e educacional da democracia. E, assim, "uma vez desencadeado o processo, as duas forças mutuamente se acrescentam": a democracia da sociedade estimula a experiência educativa democraticamente efetivada, assim como a filosofia educacional democrática fortalece os laços comunicativos no sentido da democracia. Trata-se, enfim, de "processos dinâmicos, em mútua interação, ambos modificando-se, evoluindo e, na realidade, criando-se e recriando-se, constante e continuamente, no jogo de influências mútuas em que se correlacionam"288.

Educação e democracia, em suma, configuram-se, para Dewey, como experiências absolutamente vinculadas, numa relação positiva em que, processualmente, numa espiral positiva contínua, cognitiva e moral, uma e outra se pressupõem, refinam-se, enriquecemse, adensam-se e se reconstroem.

${ }^{287}$ MEAD, Mind, self and society, 1992, p. 308.

${ }^{288}$ TEIXEIRA, Anísio. Nota Introdutória. BENJAMIN, Harold R. W. A educação e o ideal democrático. Trad. Beatriz Osório. Série VII - Cursos e conferências Vol. 02. Rio de Janeiro: Instituto Nacional de Estudos Pedagógicos - INEP/MEC, 1960, p. 09 e 10. 


\section{EDUCAÇÃO E DEMOCRACIA NA FILOSOFIA SOCIAL DE JÜRGEN HABERMAS}

A filosofia social de Jürgen Habermas se desenvolve no âmbito da Escola de Frankfurt. A tradição filosófica remete ao grupo de intelectuais ligados ao Instituto de Pesquisa Social - criado em 1923 e sediado na aludida cidade alemã -, cujos diferentes enfoques confluem no ponto de uma teoria crítica da sociedade e do conhecimento por ela produzido, com caráter interdisciplinar e orientada à práxis social emancipatória ${ }^{1}$.

Habermas é considerado o principal representante da "segunda geração" da Escola, emergindo seu pensamento como herdeiro das reflexões de Theodor Adorno, Max Horkheimer, dentro outros frankfurtianos da "geração" anterior ${ }^{2}$. Sua obra, contudo, em

${ }^{1}$ FREITAG, Bárbara. A teoria crítica: ontem e hoje. São Paulo: Brasiliense, 2004, p. 09; NOBRE, Marcos. Luta por reconhecimento: Axel Honneth e a teoria crítica. In HONNETH, Axel. Luta por reconhecimento: a gramática moral dos conflitos sociais. Trad. Luiz Repa. São Paulo: Editora 34, 2009, p. 07 e 09.

${ }^{2}$ BITTAR, Eduardo C. B. Justiça e emancipação: reflexões jusfilosóficas a partir do pensamento de Jürgen Habermas. Tese apresentada em concurso de Professor Titular junto ao Departamento de Filosofia e Teoria Geral do Direito da Faculdade de Direito da Universidade de São Paulo. São Paulo, 2011, p. 23. 
diálogo contínuo com diferentes autores, de distintas áreas e perspectivas do saber incluindo a filosofia pragmatista de Peirce, Mead e Dewey e a psicologia de Piaget e Kohlberg $^{3}$ - se destaca ao reinventar "a possibilidade de alternativamente pensar além dos limites paradigmáticos desta herança" ${ }^{4}$.

A crítica da razão instrumental, identificando a conversão do potencial emancipatório da razão, na modernidade, em instrumento de opressão, e o diagnóstico autodestrutivo da Aufklärung, detentora, em si, do germe para a regressão - presentes na Dialética do esclarecimento - instalaram, definitivamente, o pessimismo na teoria crítica ${ }^{5}$. Colocaram em cheque "a própria possibilidade da crítica e da emancipação"6.

Seguindo o diagnóstico da "primeira geração", Habermas identifica a realização deformada e empobrecida da razão no curso da modernidade. Desdobrou-se em três momentos constitutivos - cognitivo-instrumental, prático-moral e estético-expressivo -, permitindo "dissociar e desenvolver a tradição cultural, sob cada um dos aspectos da racionalidade, em questões de verdade, da justiça ou do gosto" "7. Porém, ao mesmo tempo, nas sociedades modernas ocidentais, a autocompreensão da razão acabou, de forma patológica, reduzida ao primeiro aspecto referido, cognitivo-instrumental, centrado no sujeito que conhece, manipula e dispõe da natureza objetivada. E, assim atualizada, fez-se como "produto de uma separação e usurpação, ou seja, de um processo social em cujo curso um momento subordinado ocupou o lugar do todo, sem possuir a força para assimilar a estrutura do todo",

Na esfera da vida em sociedade, concebida pelo autor, concomitantemente, como sistema e mundo da vida, isso aparece na forma de uma ironia no esclarecimento. No processo de racionalização da práxis social cotidiana, diferenciam-se sistemas parciais de ação em que os indivíduos orientam-se por fins, a partir da supramencionada perspectiva

\footnotetext{
${ }^{3}$ PINZANI, Alessandro. Habermas. Porto Alegre: Artmed, 2009, p. 09 e 21.

${ }^{4}$ BITTAR, Justiça e emancipação, 2011, p. 26.

5 BITTAR, Justiça e emancipação, 2011, p. 27; ADORNO, Theodor; HORKHEIMER, Max. Dialética do esclarecimento. Fragmentos filosóficos. Trad. Guido de Almeida. Rio de Janeiro: Zahar, 1985, p. 13.

${ }^{6}$ NOBRE, Luta por reconhecimento: Axel Honneth e a teoria crítica, 2009, p. 12.

${ }^{7}$ HABERMAS, Jürgen. Modernidade - um projeto inacabado. In ARANTES, Otília B. Fiori e ARANTES, Paulo Eduardo. Um ponto cego no projeto moderno de Jürgen Habermas: arquitetura e dimensão estética depois das vanguardas. São Paulo: Brasiliense, 1992, p. 111 e 112; HABERMAS, Jürgen. Consciência moral e agir comunicativo. Trad. Guido de Almeida. Rio de Janeiro: Tempo brasileiro, 2003, p. 32.

${ }^{8}$ HABERMAS, Jürgen. $O$ discurso filosófico da modernidade. Trad. Luiz Sérgio Repa e Rodnei Nascimento. São Paulo: Martins Fontes, 2002, p. 438. HABERMAS, Jürgen. Teoria do agir comunicativo. Racionalidade da ação e racionalização social. Tomo 01. Trad. Paulo Astor Soethe. Rev. Téc. Flávio Beno Siebeneichler. São Paulo: WMF Martins Fontes, 2012, p. 35, 132 e 674.
} 
instrumental da razão. Habermas destaca, aqui, o sistema econômico e o político, diferenciados pelos meios de comunicação não linguísticos dinheiro e poder, que passam a predominar nas relações sociais. Tais sistemas parciais voltam-se, assim, contra o mundo da vida racionalizado do qual derivaram, isto é, o horizonte experiencial em que os atores sociais, que agem comunicativamente, numa relação sujeito-sujeito (falante e ouvinte) e não sujeito-objeto, "se encontram desde sempre" e do qual extraem os recursos hermenêuticos aos processos de entendimento mútuo. E, então, colonizam-no, de forma a corromper e desvirtuar, de modo fulcral, a comunicação linguística - o lugar da razão, na filosofia habermasiana. Como resume o autor: "a racionalização do mundo da vida torna possível uma espécie de integração sistêmica que entra em concorrência com o princípio integrativo do entendimento e, de sua parte e sob determinadas condições, retroage no mundo da vida, de modo desintegrador"" .

Tal diagnóstico não implica, porém, para Habermas, o esgotamento do projeto moderno emancipatório, por meio da razão. Revisita-o criticamente, movendo-se, em sua teoria do agir comunicativo, da filosofia da consciência, dentro da qual, a seu ver, "o programa da teoria crítica em sua fase inicial fracassou", para o paradigma da filosofia da linguagem. Aqui, pode reconstruir o conceito de racionalidade, de forma ampliada, a abranger todos os seus momentos constitutivos, concebendo-a, sob a perspectiva comunicativa, no plano da "intersubjetividade de um possível entendimento". Com isso,

(...) deixa de ser paradigmática a relação que o sujeito isolado mantém com alguma coisa apresentável e manipulável no mundo, e passa a ser paradigmática a relação intersubjetiva assumida por sujeitos aptos a falar e agir, quando se entendem uns com os outros sobre alguma coisa. Para tanto, os que agem de maneira comunicativa movimentam-se no medium de uma linguagem natural e fazem uso de interpretações legadas pela tradição, ao mesmo tempo em que se referem a alguma coisa no mundo objetivo único, em seu mundo social partilhado e no respectivo mundo subjetivo $^{10}$.

9 HABERMAS, Consciência moral e agir comunicativo, 2003, p. 166; HABERMAS, Teoria do agir comunicativo, Tomo 01, 2012, p. 35, 587, 589, 590 e 591; HABERMAS, Jürgen. Teoria do agir comunicativo. Sobre a crítica da razão funcionalista. Tomo 02. Trad. Flávio Beno Siebeneichler. São Paulo: WMF Martins Fontes, 2012, p. 218, 220, 275, 277, 280, 281 e 355.

${ }^{10}$ HABERMAS, Teoria do agir comunicativo, Tomo 01, 2012, p. 592, 665 e 674. 
A emancipação liga-se ao potencial de racionalidade comunicativa imanente ao uso da linguagem voltado ao entendimento mútuo e que faz da linguagem o "critério do processo de emancipação da humanidade"11.

Trata-se de um potencial que, absolutamente, não é estranho à modernidade. E isso, não obstante o empobrecimento, derivado do modo de vida burguês, da interação comunicativa cotidiana, reprimida por coações sistêmicas, oriundas da organização estatal capitalista; contaminada pelos meios dinheiro e poder; e, enfim, instrumentalizada no âmbito do agir estratégico, orientado ao êxito individual, em detrimento do outro, reificado e dessignificado da condição de pessoa ${ }^{12}$. Afinal, apesar disso tudo, a ação orientada ao entendimento continua presente, ainda que muitas vezes represada,

(...) no processo de reprodução cultural que permite a continuidade de interpretações de interpretações do mundo, nas próprias instituições em que o indivíduo é socializado, nos processos de aprendizado e de constituição da personalidade. A racionalidade comunicativa encontra-se, assim, para Habermas, efetivamente inscrita na realidade das relações sociais contemporâneas ${ }^{13}$.

Nesse sentido, no desempenho da razão moderna, cindida nas três dimensões referidas - cada qual, acrescenta-se, cartesianamente encapsulada em "culturas de especialistas" (as ciências; a moral e o direito positivo; a arte) -, Habermas não abdica, absolutamente, dos progressos técnico-científicos, referidos ao momento instrumental, hipertrofiado. Contudo, a seu ver, é imprescindível reorientá-lo, reconduzindo-o aos limites da reprodução material da sociedade, dentro dos quais lhe cumpre atuar. E, assim, num processo de "descolonização", permitir que as instituições e os processos linguisticos de entendimento, que tem lugar no mundo da vida, funcionem como a moldura, impregnada de razão comunicativa, que submete e determina a manutenção dos sistemas ${ }^{14}$.

Em suma, para além da saída do homem da menoridade, no sentido kantiano da incapacidade de "se servir do entendimento sem a orientação de outrem"15, o

${ }^{11}$ SIEBENEICHLER, Flávio Bueno. Jürgen Habermas: razão comunicativa e emancipação. $3^{\mathrm{a}}$ ed. Rio de Janeiro: Tempo Brasileiro, 1989, p. 47e 50.

${ }^{12}$ HABERMAS, Teoria do agir comunicativo, Tomo 02, 2012, p. 334, 355, 587, 588, 595 e 601

${ }^{13}$ NOBRE, Luta por reconhecimento: Axel Honneth e a teoria crítica, 2009, p. 14.

${ }^{14}$ HABERMAS, Jürgen, Teoría y praxis: estudios de filosofia social. Trad. Salvador Más Torres e Carlos Moya Espí. 2ª ed. Madrid: Tecnos, 1990, p. 324; HABERMAS, Consciência moral e agir comunicativo, 2003, p. 32 e 33; HABERMAS, Teoria do agir comunicativo, Tomo 01, 2012, p. 138; HABERMAS, Teoria do agir comunicativo, Tomo 02, 2012, p. 253 e 334; FREITAG, Teoria crítica, 2004, p. 63.

${ }^{15}$ KANT, Immanuel. Resposta à pergunta: que é o Iluminismo? In KANT, Immanuel. A paz perpétua e outros opúsculos. Trad. Artur Morão. Lisboa: Edições 70, 2004, p. 11. 
esclarecimento, no pensamento habermasiano, volta-se para a superação da incapacidade de se servir da razão comunicativa ${ }^{16}$.

Operando no interior da modernidade, Habermas apresenta perspectiva revisora um esclarecimento bi-iluminista ${ }^{17}$ - que, sem se fazer antimodernidade, "pretende reconquistar a tradição emancipatória da modernidade não realizada"18, resgatando criticamente seu projeto inacabado. Como destaca: "Penso que antes deveríamos aprender com os desacertos que acompanharam o projeto de modernidade, com os erros dos ambiciosos programas de superação, ao invés de dar por perdidos a própria modernidade e seu projeto" $" 19$.

Tal é a abordagem dentro da qual constrói sua filosofia política e do direito, projetando modelo de democracia a partir do conceito de discurso, a práxis argumentativa que se coloca como forma reflexiva do agir comunicativo ${ }^{20}$. Também em Habermas, a democracia é o lugar social da emancipação. Voltando-se à consolidação e o fortalecimento da experiência democrática, é possível deduzir, também, do pensamento habermasiano, linhas e potencialidades de uma pedagogia da ação comunicativa - na expressão de José Pedro Boufleuer ${ }^{21}$-, já dito, não formulada, de modo acabado e sistematizada, pelo filósofo.

Para isso, o presente capítulo dedica-se à reflexão sobre educação e democracia na filosofia social de Jürgen Habermas, seguindo organização expositiva similar à adotada anteriormente, na apreensão do pensamento deweyano. Em primeiro lugar, são analisados pontos fundamentais de sua perspectiva crítica revisora da modernidade, passando por sua teoria de racionalidade e do agir comunicativo; a concepção moral procedimental, cognitivista e intersubjetivista consolidada em sua ética discursiva; e o modelo de desenvolvimento da consciência moral, em que, na revisita à teoria de Lawrence Kohlberg, coloca o discurso como a representação do mais elevado estágio de interação (pósconvencional), exprimindo a noção de autonomia.

${ }^{16}$ SIEBENEICHLER, Jürgen Habermas, 1989, p. 23.

${ }^{17}$ SIEBENEICHLER, Jürgen Habermas, 1994, p. 25.

${ }^{18}$ BITTAR, Justiça e emancipação, 2011, p. 110 e 111.

${ }^{19}$ HABERMAS, Modernidade - um projeto inacabado, 1992, p. 118.

${ }^{20}$ HABERMAS, Jürgen. Verdade e justificação. Ensaios filosóficos. Trad. Milton Camargo Mota. $2^{2}$ ed. São Paulo: Loyola, 2009, p. 101.

${ }^{21}$ BOUFLEUER, José Pedro. Pedagogia da ação comunicativa. Uma leitura de Habermas. $3^{\underline{a}}$ ed. Ijuí: Unijuí, 2001. 
Feito isso, pode ser compreendida e aprofundada devidamente sua teoria da democracia. Insurgindo-se contra o estreitamento do sentido da prática democrática ${ }^{22}$, concebe-a como experiência ampliada de autodeterminação, conferindo destaque ao momento comunicativo da interação social, enraizado no mundo da vida, que se distingue das estruturas sistêmicas do mercado e da política. Envolve, nessa medida, um fluxo comunicacional que se inicia com a atuação da sociedade civil, no âmbito da esfera pública - a "arena para a percepção, a identificação e o tratamento de problemas de toda a sociedade" -, encontrando eco no sistema político, onde podem ser institucionalmente solucionados, pelo medium do direito. Parte, assim, da ideia de "processos e pressupostos comunicativos de formação democrática da opinião e da vontade (que) funcionam como a comporta mais importante para a racionalização discursiva das decisões de um governo e de uma administração vinculados ao direito e a lei”. Eis o critério de que se dispõe, em condições pós-metafísicas, para a legitimidade, gerada a partir da legalidade democrática $^{23}$.

E, com a aplicação, no campo da educação, dos conceitos de agir comunicativo, discurso, ética discursiva e desenvolvimento moral, na forma como construídos por Habermas, infere-se, por fim, a aludida pedagogia da ação comunicativa, como processo educacional dialógico na direção da experiência cognitiva e moral pós-convencional (autônoma) e, nessa medida, coadunada à convivência democrática.

Em todos os pontos, a despeito das diferenças entre os percursos teóricos pelos quais caminham e as tradições filosóficas em que se inserem - ambas, no final das contas, vinculadas à mesma "família intelectual" 24 , o iluminismo -, as convergências com filosofia social de John Dewey saltam aos olhos.

22 AVRITZER, Leonardo. A moralidade da democracia: ensaios em teoria habermasiana e teoria democrática. São Paulo: Perspectiva; Belo Horizonte: Editora UFMG, 1996, p. 19 e 20.

${ }^{23}$ HABERMAS, Jurgen. Direito e democracia: entre factibilidade e validade. Volume 01. $2^{\mathrm{a}}$ Ed. Trad. Flávio Beno Siebeneichler. Rio de Janeiro: Tempo Brasileiro, 2012, p. 188; HABERMAS, Jurgen. Direito e democracia: entre factibilidade e validade. Volume 02. 1 $1^{\mathrm{a}}$ Ed. Trad. Flávio Beno Siebeneichler. Rio de Janeiro: Tempo Brasileiro, 2011, p. 22, 23, 24 e 92; HABERMAS, Jürgen. A inclusão do outro. Estudos de teoria política. Trad. George Sperber, Paulo Astor Soethe e Milton Camargo Mota. 3ª ed. São Paulo: Loyola, 2007 , p. 278 e 289.

${ }^{24}$ HOBSBAWN, Eric. Sobre história. Ensaios. Trad. Cid K. Moreira. São Paulo: Cia das Letras, 2013, p. 349. 


\section{A modernidade e a crítica na filosofia social de Jürgen Habermas: razão e agir comunicativo, discurso e desenvolvimento da consciência moral}

A compreensão profunda do diagnóstico de modernidade e das perspectivas emancipatórias que nela se desenham, no âmbito da filosofia social habermasiana, exige, como tarefa inicial, a apreensão do conceito atribuído, pelo autor, à racionalidade que rege a reflexão, a ação e interação humana.

É em seu bojo que Habermas constrói o entendimento sobre a sociedade, seu percurso histórico e o descaminho em que, na modernidade, vê-se paradoxalmente presa. É a partir dela, em sua perspectiva comunicativa - envolvida na configuração do agir comunicativo e do discurso, na concepção moral discursiva e no processo de formação social da individualidade, num movimento de desenvolvimento moral cognitivista -, que entrevê a possibilidade da efetivação do projeto moderno inacabado.

1.1. A racionalidade, para Habermas, mantém estreita relação com o saber, concebido na mediação pela comunicação. E mais, um saber que, na medida em que, na interação comunicativa, pode ser criticado e, com boas razões, fundamentado, indica uma pretensão de validade, à qual se reconhece o atributo da confiabilidade ${ }^{25}$.

$\mathrm{Na}$ mudança de perspectiva da filosofia da consciência para a filosofia da linguagem - tal como fizera Dewey, em sua reconstrução filosófica -, pode superar o conceito cognitivo-instrumental de racionalidade, para o qual são paradigmáticos a relação que o sujeito solitário mantém com o mundo objetivado e o uso não comunicativo do saber em ações orientadas à autoafirmação exitosa. Desse modo, aqui, a razão encontra sua medida, exclusivamente, "nos critérios de verdade e êxito, que regulam relações do sujeito que conhece e age segundo fins com o mundo de objetos ou estados de coisas possíveis"26.

Já a concepção de racionalidade comunicativa, propugnada pelo autor:

(...) traz consigo conotações que, no fundo, retrocedem à experiência central da força espontaneamente unitiva e geradora de consenso própria à fala argumentativa, em que diversos participantes superam suas concepções inicialmente subjetivas para então, graças à concordância de convicções racionalmente motivadas, assegurar-se ao mesmo tempo da

\footnotetext{
${ }^{25}$ HABERMAS, Teoria do agir comunicativo, Tomo 01, 2012, p. 31, 32, 34 e 45; HABERMAS, O discurso filosófico da modernidade, 2002, p. 437.

${ }^{26}$ HABERMAS, $O$ discurso filosófico da modernidade, 2002, p. 437; HABERMAS, Teoria do agir comunicativo, Tomo 01, 2012, p. 35 e 674.
} 
unidade do mundo objetivo e da intersubjetividade de seu contexto vital $^{27}$.

Trata-se de uma racionalidade que, imanente à interação linguística, remete, fundamentalmente, à práxis argumentativa, orientada ao entendimento intersubjetivo: o "discurso em que os participantes da argumentação tematizam pretensões de validade controversas e procuram resolvê-las ou criticá-las com argumentos". Induz, enfim, a ideia de resgate discursivo de pretensões de validade criticáveis, que precisam "ao fim e ao cabo, sustentar-se sobre razões"28.

Sendo assim, o predicado racional pode ser atribuído a dois sujeitos gramaticais. Racional pode ser a exteriorização, a fala, a ação, que concretiza um saber, em virtude de sua disposição à crítica e de sua capacidade de fundamentação. E pode ser, precipuamente, a pessoa que dispõe do saber e que se revela hábil a exteriorizações e comportamentos racionais, no sentido supramencionado. A predicação indica, assim, a disposição e a capacidade do sujeito de, frente à crítica à qual está aberto - e agora no âmbito da argumentação -, apresentar, ele mesmo, fundamentos na forma de boas razões ${ }^{29}$. Em suma, é racional a pessoa capaz de falar e agir que "pode prestar contas de sua orientação por pretensões de validade" $" 30$.

Por tudo isso, a relação com a racionalidade faz pertencer à gramática do conhecimento a possibilidade de ser criticado e a exigência de que seja fundamentado. $\mathrm{Na}$ mesma linha do pragmatismo deweyano, o saber se apresenta, inevitavelmente, como pretensão falível, aberta à crítica potencial na intersubjetividade do discurso ${ }^{31}$. A racionalidade, enfim, não demanda a verdade de um saber; apenas, sua confiabilidade, isto é, sua aceitabilidade fundamentada:

Quem compartilha concepções que se revelam falsas não é eo ipso irracional; irracional é quem defende suas opiniões dogmaticamente, se prende a elas mesmo vendo que não pode fundamentá-las. Para qualificar uma opinião como racional basta que, no contexto de justificação dado,

${ }^{27}$ HABERMAS, Teoria do agir comunicativo, Tomo 01, 2012, p. 37.

${ }^{28}$ HABERMAS, Verdade e justificação, 2009, p. 109; HABERMAS, Teoria do agir comunicativo, Tomo 01, 2012, p. 35, 47 e 48.

${ }^{29}$ HABERMAS, Teoria do agir comunicativo, Tomo 01, 2012, p. 31, 32, 34, 39, 45, 47 e 56.

${ }^{30}$ HABERMAS, Verdade e justificação, 2009, p. 102.

${ }^{31}$ DEWEY, John. Experiência e natureza. In DEWEY, John. Experiência e natureza; Lógica: a teoria da investigação; A arte como experiência; Vida e educação; Teoria da vida moral. Trad. Murilo Otávio Rodrigues Paes Leme, Anísio S. Teixeira e Leônidas Gontijo de Carvalho. Coleção Os Pensadores. São Paulo: Abril Cultural, 1980, p. 29; BERNSTEIN, Richard J. The resurgence of pragmatism. Social research, vol. $59, \mathrm{n}^{\mathrm{O}} 4,1992$, p. 814 . 
ela possa por bons motivos ser tida como verdadeira, ou seja, racionalmente aceita ${ }^{32}$.

Sendo assim, a racionalidade comunicativa é referida ao êxito - Habermas dirá ilocucionário - de processos linguísticos orientados ao entendimento, entre sujeitos comunicativamente competentes. Quanto ao entendimento, definido como processo de unificação, um "procedimento cooperativo de interpretação, voltado a alcançar definições situacionais intersubjetivamente reconhecidas", é apreendido como telos da linguagem ${ }^{33}$.

Citando Humbolt, Habermas destaca, na linguagem, o aspecto pragmático do "emprego vivo da fala". A conversação aparece em primeiro plano, como práxis na qual os falantes, superando o particularismo semântico, "querem se compreender mutuamente e ao mesmo tempo se entender a respeito de alguma coisa, ou seja, alcançar um possível acordo,, 34 .

Sem estabelecer um precipitado vínculo necessário entre linguagem e entendimento, defende, com amparo nos estudos de Austin e Strawson, o uso da linguagem orientado pelo entendimento como seu modus original. Frente a ele, a utilização subordinada a um fim que não se esgota na comunicação comporta-se de maneira parasitária $^{35}$.

Austin distingue atos locucionários, ilocucionários e perlocucionários. O termo locucionário remete ao teor da proposição ("p"), de modo que "Com atos locucionários o falante expressa estados de coisas; diz algo". Com os atos ilocucionários, por sua vez, “o falante executa uma ação ao dizer algo. O papel ilocucionário fixa o modus de uma sentença ("M p"), empregada como asserção, promessa, comando, confissão, etc.". Finalmente, com os atos perlocucionários, "o falante almeja desencadear um efeito no ouvinte. Ao executar uma ação de fala, realiza algo no mundo”. Assim, os atos de fala caracterizam-se por: "dizer algo; agir enquanto se diz algo; realizar algo por meio de se estar agindo enquanto se diz algo"36.

${ }^{32}$ HABERMAS, Verdade e justificação, 2009, p. 104 e 105.

${ }^{33}$ HABERMAS, Teoria do agir comunicativo, Tomo 01, 2012, p. 40, 42, 138, 497 e 498.

${ }^{34}$ HABERMAS, Verdade e justificação, 2009, p. 65 e 69.

${ }^{35}$ HABERMAS, Verdade e justificação, 2009, p. 124 e 125; HABERMAS, Teoria do agir comunicativo, Tomo 01, 2012, p. 500.

${ }^{36}$ HABERMAS, Teoria do agir comunicativo, Tomo 01, 2012, p. 500 e 501. 
Dessa forma, a ação de fala ilocucionária ("M p"), composta pelo elemento constitutivo ilocucionário e o proposicional, apresenta-se, para Austin, como um "ato perficiente, externado sempre com intenção comunicativa - ou seja, com o objetivo de que um falante queira compreender a externação proposta e aceitá-la”. E isso, de modo tal que, nela, "a intenção comunicativa do falante e o objetivo ilocucionário por ele almejado resultam do significado manifesto do que se disse",37.

Quanto aos efeitos perlocucionários, surgem quando as ações de fala desempenham um papel instrumental em contextos teleológicos de ação. $\mathrm{O}$ comunicante não persegue as metas ilocucionárias da comunicação "sem reservas". Nas perlocuções, "um falante age orientado pelo êxito e vincula, ao mesmo tempo, ações de fala a intenções, instrumentalizando-as (as ações de fala) para determinados fins que mantém uma relação apenas contingente com o significado do que se disse" ${ }^{, 38}$. Em resumo:

O fim ilocucionário que o falante persegue por meio de uma externação surge do próprio significado do que tenha dito, e tal significado é constitutivo para as ações de fala (...) Sua intenção comunicativa esgotase no fato de que cabe ao ouvinte entender o teor manifesto da ação de fala. Ao contrário, o fim perlocucionário de um falante (...) não surge do teor manifesto da ação de fala; só se pode desvendar esse fim por meio da intenção de quem age ${ }^{39}$.

Nessa linha, Habermas acrescenta, agora com base em Strawson, que, diferentemente do que ocorre com os fins ilocucionários, os quais somente podem ser alcançados fazendo-se expressos - "Ilocuções são externadas abertamente" -, em relação aos fins perlocucionários, o falante, para que tenha êxito, não pode dar a conhecê-los, tampouco admiti-los como tais. Pois somente podem ser alcançados de maneira inconspícua; na medida em que permanecem latentes ${ }^{40}$.

De qualquer forma, tais efeitos perlocucionários não dispensam o auxílio das ações de fala "incluídas como meios em ações teleológicas orientadas ao êxito". E isso de maneira tal que o fim não ilocucionário de influenciação do ouvinte somente tem lugar caso a comunicação instrumentalizada seja apropriada à obtenção de fins ilocucionários ${ }^{41}$.

\footnotetext{
${ }^{37}$ HABERMAS, Teoria do agir comunicativo, Tomo 01, 2012, p. 501.

${ }^{38}$ HABERMAS, Verdade e justificação, 2009, p. 123; HABERMAS, Teoria do agir comunicativo, Tomo 01, 2012 , p. 502.

${ }^{39}$ HABERMAS, Teoria do agir comunicativo, Tomo 01, 2012, p. 503.

${ }^{40}$ HABERMAS, Verdade e justificação, 2009, p. 121 e 122; HABERMAS, Teoria do agir comunicativo, Tomo 01, 2012, p. 506.

${ }^{41}$ HABERMAS, Teoria do agir comunicativo, Tomo 01, 2012, p. 507.
} 
É por isso, conclui Habermas, que o " "uso da linguagem orientado segundo consequências' não é um uso originário da linguagem, mas a subsunção, sob condições de um agir orientado pelo êxito, de ações que se prestem a fins ilocucionários”. O modus original de uso da linguagem, repisa-se, remete à orientação ao entendimento, compreendido tão somente com base em atos ilocucionários: "Uma tentativa de entendimento feita com auxílio de um ato de fala obtém sucesso quando um falante alcança seu objetivo ilocucionário",42.

O êxito ilocucionário do ato comunicativo, enfim, "mede-se pelo reconhecimento intersubjetivo que a pretensão de validade levantada por meio dele encontra" ${ }^{43}$. Indica o entendimento, a consecução, portanto, do objetivo precípuo e originário da linguagem, a que se volta a racionalidade comunicativa habermasiana.

Nessa perspectiva, a racionalidade adquire um sentido bastante ampliado, não se restringindo ao conhecimento e controle bem-sucedido do entorno físico, pelo sujeito. A apreensão fundamentada e, nessa extensão, verdadeira do ambiente e a ação eficiente sobre ele constituem, sem dúvida, sinais de racionalidade, no enfoque cognitivoinstrumental: "Denominamos racionais os sujeitos capazes de agir e falar que na medida do possível não se enganam quanto a fatos e relações entre meio e fim" ${ }^{\text {". }}$.

Mas o desdobramento da razão, como antecipado, remete, ainda, a outros momentos característicos ${ }^{45}$. Há, de fato, outros tipos de manifestações e ações a que não se vinculam pretensões de verdade e eficácia e que, ainda assim, podem contar com o respaldo de boas razões, em contextos de comunicação. Desse modo, complementa Habermas:

(...) também é assim chamado racional quem segue uma norma vigente e se mostra capaz de justificar seu agir em face de um crítico, tratando de explicar uma situação dada à luz de expectativas comportamentais legítimas. E é chamado de racional até mesmo quem exterioriza de maneira sincera um desejo, um sentimento ou um estado de espírito, quem revela um segredo, admite ter cometido um ato qualquer, etc., e então se mostra capaz de dar a um crítico a certeza dessa vivência

${ }^{42}$ HABERMAS, Teoria do agir comunicativo, Tomo 01, 2012, p. 507 e 508.

${ }^{43}$ HABERMAS, Verdade e justificação, 2009, p. 109.

${ }^{44}$ HABERMAS, Teoria do agir comunicativo, Tomo 01, 2012, p. 34, 42 e 43.

${ }^{45}$ HABERMAS, Modernidade - um projeto inacabado, 1992, p. 109; HABERMAS, Consciência moral $e$ agir comunicativo, 2003, p. 32, HABERMAS, Teoria do agir comunicativo, Tomo 02, 2012, p. 589. 
relevada, tratando de tirar consequências práticas disso e comportar-se a partir dali de maneira consistente ${ }^{46}$.

Habermas fala, nesse sentido, em três mundos que constituem um sistema de referências, suposto nos processos de comunicação e com o qual os sujeitos comunicantes estabelecem "sobre o que é possível haver entendimento": i) o mundo objetivo, enquanto "totalidade de estados de coisas existentes", o "conjunto de todas as entidades sobre as quais é possível haver enunciados verdadeiros"; ii) o mundo social, como "conjunto de todas as relações interpessoais legitimamente reguladas" de um grupo social; e, por fim, iii) o mundo subjetivo, como conjunto das vivências a que o falante tem um acesso privilegiado $^{47}$. Afinal,

Os atos de fala não servem apenas para a representação (ou pressuposição) de estados e acontecimentos, quando o falante se refere a algo no mundo objetivo. Eles servem ao mesmo tempo para a produção (ou renovação) de relações interpessoais, quando o falante se refere a algo no mundo social das interações legitimamente reguladas, bem como para a manifestação de vivências, isto é, para a autorrepresentação, quando o falante se refere a algo no mundo subjetivo, a que tem acesso privilegiado ${ }^{48}$.

Diante dessas referências ao mundo, o agente apresenta, com suas exteriorizações e comportamentos, três modalidades de pretensões de validade, suscetíveis de crítica e de fundamentação. São elas: i) pretensão de verdade, relativa "a fatos que afirmamos com referência a objetos no mundo objetivo"; ii) pretensão de correção de "normas e pretensões, que merecem reconhecimento num mundo social intersubjetivamente partilhado"; e, finalmente, iii) pretensão de veracidade/sinceridade, quanto a enunciados que revelam vivências subjetivas; "de que a intenção expressa do falante corresponda ao que ele pensa"49.

Sob a perspectiva comunicativa, desse modo, a razão se abre às três dimensões constitutivas (cognitivo-instrumental; prático-moral; e estético-expressivo), no âmbito de um conceito procedural, referido à práxis linguística argumentativa, voltada ao

${ }^{46}$ HABERMAS, Teoria do agir comunicativo, Tomo 01, 2012, p. 43 e 44.

47 HABERMAS, Consciência moral e agir comunicativo, 2003, p. 79; HABERMAS, Teoria do agir comunicativo, Tomo 01, 2012, p. 137, 162, 192, 193 e 533.

${ }^{48}$ HABERMAS, Consciência moral e agir comunicativo, 2003, p. 167.

${ }^{49}$ HABERMAS, Consciência moral e agir comunicativo, 2003, p. 79, 167 e 168; HABERMAS, Verdade e justificação, 2009, p. 109; HABERMAS, Teoria do agir comunicativo, Tomo 01, 2012, p. 192 e 193. 
entendimento sobre pretensões de verdade proposicional, correção normativa e veracidade subjetiva (Habermas fala, aqui, também, de adequação estética) ${ }^{50}$.

1.2. Tal conceito ampliado de racionalidade estende-se, para além de proferimentos verbais, a ações e interações. Remete, assim, à concepção de agir comunicativo, orientado ao entendimento mútuo: a resposta mais adequada, para Habermas, em vista da coordenação social, numa perspectiva cooperativa e emancipatória ${ }^{51}$.

$\mathrm{Na}$ ação comunicativa, o entendimento linguístico aparece como o mecanismo de coordenação social que, "em face dos planos de ação e das atividades propositadas dos envolvidos, integra tais planos e atividades à interação"

As interações, dessa forma, não se degeneram num conjunto de ações monologicamente orientadas e concatenadas a partir de cálculos egocêntricos de ganhos. Isso corresponde a importar, para o âmbito da experiência social, reificando-a, a racionalidade própria ao enfrentamento cognitivo-instrumental da natureza. É, afinal, o que se identifica nas sociedades modernas ${ }^{53}$.

O agir comunicativo indica a experiência social em que os sujeitos, incorporando à sua fala e comportamento pretensões de validade criticáveis, "coordenam seus planos de ação mediante o entendimento mútuo linguístico". Vincula o processo de entendimento, em que os membros do grupo social, no medium linguístico e a partir do horizonte do mundo da vida compartilhado, referem-se a algo no mundo objetivo, social e subjetivo e, ao fazê-lo, manifestam pretensões de validade que podem ser aceitas ou contestadas ${ }^{54}$.

Em síntese, Habermas fala em agir comunicativo quando "os participantes não se orientam em primeira linha pelo êxito de si mesmos"; eles se empenham em harmonizar seus planos de ação e somente perseguir seus respectivos fins sob a condição de um "acordo existente ou a se negociar sobre a situação e as consequências esperadas": um

\footnotetext{
${ }^{50}$ HABERMAS, O discurso filosófico da modernidade, 2002, p. 437.

${ }^{51}$ HABERMAS, Consciência moral e agir comunicativo, 2003, p. 164 e 165; HABERMAS, Verdade e justificação, 2009, p. 117.

${ }_{52}$ HABERMAS, Teoria do agir comunicativo, Tomo 01, 2012, p. 182, 183, 184 e 191.

53 HABERMAS, Consciência moral e agir comunicativo, 2003, p. 165; HABERMAS, Teoria do agir comunicativo, Tomo 01, 2012, p. 132 e 496.

${ }^{54}$ HABERMAS, Verdade e justificação, 2009, p. 118; HABERMAS, Teoria do agir comunicativo, Tomo 01, 2012, p. 183, 191, 528 e 529.
} 
entendimento apoiado, ao mesmo tempo, "num saber proposicional, compartilhado intersubjetivamente, numa concordância normativa e numa confiança recíproca” ${ }^{\text {} 55}$.

Nesse quadro, somente são incluídos no conceito assim delineado, "as interações mediadas pela linguagem nas quais todos os participantes buscam atingir fins ilocucionários, e tão somente fins como esses" ${ }^{, 56}$.

O assentimento, com o "sim", às pretensões de validade lançadas pelo participante da interação implica a continuidade da prática comunicativa da vida cotidiana, sob o pano de fundo do mundo da vida, constituído de convicções subjacentes mais ou menos difusas e isentas de problemas ${ }^{57}$.

Entretanto, porque suscetível de crítica, o receptor pode, também, com um "não", rejeitar a oferta de fala, contestando sua validade sob o aspecto de sua verdade, de sua correção normativa e/ou de sua sinceridade. Nesse momento, em que a pretensão de validade do ato de fala ofertado é problematizada, tornando-se objeto de uma controvérsia em que pode ser resgatada com base em argumentos, os "envolvidos passam (mesmo que de modo rudimentar) do agir comunicativo para outra forma de comunicação, a saber, para uma práxis argumentativa em que desejam se convencer mutuamente, mas também aprender uns com os outros" ${ }^{, 58}$.

A racionalidade inerente à ação comunicativa cotidiana induz, desse modo, a possibilidade, a potencialidade da fundamentação ou resgate discursivo das pretensões de validade, pelo uso de argumentos, mesmo que não efetivado em todos os casos. Remete ao discurso, que funciona:

(...) como instância de apelação que possibilita dar prosseguimento ao agir comunicativo com outros meios, quando não se pode mais abrandar um dissenso por meio das rotinas do dia a dia, mas ainda se deve, não obstante, decidir sobre ele sem o emprego imediato ou estratégico da violência ${ }^{59}$.

${ }^{55}$ HABERMAS, Consciência moral e agir comunicativo, 2003, p. 165 e 167; HABERMAS, Teoria do agir comunicativo, Tomo 01, 2012, p. 496.

${ }^{56}$ HABERMAS, Teoria do agir comunicativo, Tomo 01, 2012, p. 510.

${ }^{57}$ HABERMAS, Consciência moral e agir comunicativo, 2003, p. 169; HABERMAS, Teoria do agir comunicativo, Tomo 01, 2012, p. 138.

${ }^{58}$ HABERMAS, Verdade e justificação, 2009, p. 92.

${ }^{59}$ HABERMAS, Verdade e justificação, 2009, p. 109; HABERMAS, Teoria do agir comunicativo, Tomo 01, 2012 , p. 48 e 63. 
Eis os níveis implicados em toda comunicação orientada ao entendimento mútuo: o agir e o discurso. Este último, uma forma de reflexão do agir comunicativo, no qual "as pretensões de validade, pelas quais os agentes se orientam sem problemas na prática comunicacional quotidiana, são expressamente tematizados e problematizados". E, nesse sentido, tal como a ação que as vinculam, essas pretensões são deixadas em suspenso. Os conteúdos comunicados, desprendidos do "horizonte de obviedades inquestionadas, compartidas intersubjetivamente e não tematizadas", que compõe o mundo da vida, são feitos possibilidades de fatos, regulações ou vivências, em um dos três mundos - objetivo, social e subjetivo -, que podem ou não ser o caso, conforme o potencial de razões que vinculam. Tudo no sentido da conquista, manutenção e renovação do consenso ${ }^{60}$.

$\mathrm{O}$ agir comunicativo, orientado ao entendimento, por tudo isso, apresenta-se como a alternativa emancipatória ao que Habermas denomina agir social estratégico. Neste último, orientados pelo êxito, os agentes "tentam alcançar os objetivos de sua ação influindo externamente, por meio de armas ou bens, ameaças ou seduções, sobre a definição da situação ou sobre a decisão ou motivos de seu adversário". A coordenação dos planos de ação, nesse caso, efetiva-se mediante a influenciação recíproca, "por meio de cálculos egocêntricos de êxito que se quer obter" ${ }^{\text {61 }}$.

Aqui, faz-se um uso instrumental e parasitário da linguagem, segundo o modelo de perlocuções, deixando inutilizado o potencial racional comunicativo. A comunicação linguística é "subordinada aos imperativos do agir racional orientado a fins", apropriado, em rigor, à apreensão e enfrentamento do mundo objetivo. Nesse sentido, ocupado o ator social com a influenciação calculista sobre decisões de seu oponente (não parceiro de interação), "as metas ilocucionárias só são relevantes como condições de sucessos perlocucionários", almejados por meio da comunicação ${ }^{62}$.

Se, em ambas as formas de agir social (comunicativa e estratégica), a estrutura teleológica é pressuposta, "na medida em que se atribui aos atores a capacidade de agir em vista de um objetivo e o interesse em executar seus planos de ação", na ação estratégica, o

${ }^{60}$ HABERMAS, Verdade e justificação, 2009, p. 92; HABERMAS, Consciência moral e agir comunicativo, 2003, p. 155 e 169; HABERMAS, Teoria do agir comunicativo, Tomo 01, 2012, p. 47.

${ }^{61}$ HABERMAS, Verdade e justificação, 2009, p. 118; HABERMAS, Teoria do agir comunicativo, Tomo 01, 2012, p. 495 e 496;

62 HABERMAS, Verdade e justificação, 2009, p. 118, 123 e 124; HABERMAS, Teoria do agir comunicativo, Tomo 01, 2012, p. 496, 498 e 501 
sujeito alça-a ao primeiro plano, orientando-se para o sucesso individual e fazendo da linguagem, deturpada em perlocução, apenas meio disponível em vista de seu fim, a despeito do outro ${ }^{63}$.

1.3. A ação estratégica, orientada pelo êxito, com a utilização parasitária da linguagem, remete, pois, à realização desfigurada e empobrecida da razão na história da modernidade. Aferra-se ao "controle cognitivo-instrumental sobre a natureza (e sociedade) objetivada" e, com isso, a uma autonomia reduzida à autoafirmação egoísta com respeito a fins ${ }^{64}$.

Os resultados do patológico predomínio de tal perspectiva racional, particularmente no âmbito da comunicação, são desastrosos. Conduziram ao empobrecimento e desumanização das relações sociais ${ }^{65}$. Pois "é só de maneira insatisfatória que as atividades do espírito humano podem ser restritas à confrontação cognitivo-instrumental com a natureza exterior" ${ }^{\prime 66}$. Tal abordagem não é suficiente para dar conta de conflitos sociais e morais. Ao se intrometer na esfera das relações humanas, desconhece a intersubjetividade, deturpa o uso da linguagem, faz do outro objeto e, em seguida, res, meio para a execução de planos monológicos de ação.

Com isso, ao mesmo tempo em que revela o domínio de especialidades científicas e de técnicas cada vez mais sofisticadas para a autoafirmação e controle do mundo objetivo, o homem se vê incapaz de solucionar devidamente seus problemas de convivência e coordenação social. O diagnóstico harmoniza-se com o de Dewey. A técnica e a ciência moderna, que permitiram o crescente bem-estar e a melhoria das condições materiais de vida para grande parte da população, são também instrumentos para a dominação, a violência e a eficácia destrutiva da bomba atômica e da câmara de gás. Tudo isso numa caminhada histórica em que restaram desacoplados - muitas vezes, grandezas inversamente proporcionais - o progresso técnico-científico e o desenvolvimento moral e social $^{67}$.

${ }^{63}$ HABERMAS, Consciência moral e agir comunicativo, 2003, p. 165.

${ }^{64}$ HABERMAS, $O$ discurso filosófico da modernidade, 2002, p. 438; HABERMAS, Teoria do agir comunicativo, Tomo 01, 2012, p. 37 e 132.

${ }^{65}$ BITTAR, Justiça e emancipação, 2011, p. 348 e 350; BITTAR, Eduardo C. B. Justiça e liberdade na filosofia do direito de Jürgen Habermas. Revista dos Tribunais, ano 101, vol. 918, abril/2012, p. 237.

${ }^{66}$ HABERMAS, Teoria do agir comunicativo, Tomo 01, 2012, p. 161.

${ }^{67}$ HABERMAS, Teoría y praxis, 1990, p. 324; SIEBENEICHLER, Jürgen Habermas, 1994, p.41; BITTAR, Justiça e liberdade na filosofia do direito de Jürgen Habermas, 2012, p. 236. 
Tais descaminhos da modernidade, em que a ascendência e incremento da razão conduziram à sua própria deformação, traspassa, na filosofia habermasiana, uma história social de avanços e retrocessos, em cujo curso a sociedade moderna ganhou complexidade e se diferenciou como sistema e mundo da vida ${ }^{68}$.

Habermas apresenta o mundo da vida como um conceito correlato dos processos comunicativos de entendimento. Constitui um reservatório de autoevidências e de convicções subjacentes mais ou menos difusas e isentas de problemas, que "acumula o trabalho interpretativo prestado por gerações anteriores" e do qual "os participantes da comunicação lançam mão quando se encontram em processos cooperativos de interpretação"69.

Remete à perspectiva participante, "de dentro da sociedade", do sujeito inserido nas interações comunicativas e nas situações cotidianas da vida social ${ }^{70}$. E corresponde, nessa linha, ao horizonte no qual os que agem comunicativamente se movem, formando o contexto da situação da ação e fornecendo, ao mesmo tempo, "os recursos para os processos de interpretação com os quais os participantes da comunicação procuram suprir a carência de entendimento mútuo que surgiu em cada situação de ação",71. Induz, pois,

(...) de certa forma, o lugar transcendental em que os falantes e ouvintes se encontram; onde podem levantar, uns em relação aos outros, a pretensão de que suas exteriorizações condizem com o mundo objetivo, social ou subjetivo; e onde podem criticar ou confirmar tais pretensões de validade, resolver seu dissenso e obter consenso ${ }^{72}$.

Habermas fala em três componentes estruturais do mundo da vida, correlatos aos três conceitos de mundos, a saber: a cultura, compreendida como "reserva de saber, do qual os participantes da comunicação extraem interpretações no momento em que tentam se entender sobre algo no mundo"; a sociedade, definida como as "ordens legítimas pelas quais os participantes da comunicação regulam sua pertença a grupos sociais, assegurando

68 HABERMAS, O discurso filosófico da modernidade, 2002, p. 438; HABERMAS, Teoria do agir comunicativo, Tomo 02, 2012, p. 220 e 275. BITTAR, Justiça e emancipação, 2011, p. 348.

${ }^{69}$ HABERMAS, Teoria do agir comunicativo, Tomo 01, 2012, p. 138 e 139; HABERMAS, Teoria do agir comunicativo, Tomo 02, 2012 p. 227.

${ }^{70}$ FREITAG, Teoria crítica, 2004, p. 61.

71 HABERMAS, Teoria do agir comunicativo, Tomo 01, 2012, p. 138; HABERMAS, Teoria do agir comunicativo, Tomo 02, 2012, p. 231; HABERMAS, Consciência moral e agir comunicativo, 2003, p. 167

${ }^{72}$ HABERMAS, Teoria do agir comunicativo, Tomo 02, 2012, p. 231. 
a solidariedade"; e, finalmente, a personalidade, interpretada como "conjunto de competências que tornam um sujeito capaz de fala e de ação - portanto, que o colocam em condições de participar de processos de entendimento, permitindo-lhe afirmar sua identidade" ${ }^{, 73}$.

Assim estruturado, o mundo da vida se reproduz e se renova simbolicamente na prática comunicativa cotidiana. O autor destaca, como processos de reprodução (e renovação) do mundo da vida, correspondentes aos aludidos componentes estruturais, pelo caminho do agir comunicativo: a reprodução cultural, a integração social e a socialização. Explica:

Sob o aspecto funcional do entendimento, o agir comunicativo se presta à transmissão e à renovação de um saber cultural; sob o aspecto da coordenação da ação, ele possibilita a integração social e a geração de solidariedade; e, sob o aspecto da socialização, o agir comunicativo serve à formação de identidades pessoais. As estruturas simbólicas do mundo da vida se reproduzem pelos caminhos que dão continuidade a um saber válido e que estabilizam a solidariedade grupal, formando atores imputáveis ${ }^{74}$.

Tais processos de reprodução que se estendem às estruturas simbólicas do mundo da vida podem, então, ser avaliados de acordo com a racionalidade do saber gerado e transmitido; os laços de cooperação e solidariedade dos membros; e, finalmente, a responsabilidade, a imputabilidade da personalidade adulta ${ }^{75}$.

Ao lado deles, Habermas destaca, também, a necessidade de manutenção e reprodução do substrato material do mundo da vida. E este segue "outros caminhos": "A reprodução material se efetua, por seu turno, mediante a atividade teleológica, a qual permite aos indivíduos socializados uma intervenção no mundo para a realização de seus objetivos",76.

Aqui, a ciência e a tecnologia, no enfrentamento cognitivo-instrumental da natureza, fornecendo meios para a melhoria das condições materiais de existência, revelam todo o seu potencial positivo. Mas isso de maneira que constituam instrumentos sujeitos aos sentidos traçados comunicativamente, na esfera do mundo da vida ${ }^{77}$.

\footnotetext{
${ }^{73}$ HABERMAS, Teoria do agir comunicativo, Tomo 02, 2012, p. 252 e 253.

${ }^{74}$ HABERMAS, Teoria do agir comunicativo, Tomo 02, 2012, p. 252.

${ }^{75}$ HABERMAS, Teoria do agir comunicativo, Tomo 02, 2012, p. 252.

${ }^{76}$ HABERMAS, Teoria do agir comunicativo, Tomo 02, 2012, p. 253.

${ }^{77}$ HABERMAS, Teoría y praxis, 1990, p. 318, 319 e 331.
} 
A diferenciação estrutural do mundo da vida, nos componentes cultura, sociedade e personalidade, resulta de um processo histórico de racionalização, interpretado, por Habermas, como liberação do potencial de racionalidade contido no agir comunicativo. Nele, as decisões mediante "sim"/"não", no âmbito das práticas comunicativas cotidianas, paulatinamente, deixam de ser determinadas por um acordo normativo tradicional, já concretizado e prescrito no passado, e passam a surgir "dos próprios processos de interpretação cooperativa dos participantes"

Com a atualização desse potencial, as instituições sociais vão se distinguindo das cosmovisões, diferenciando-se cultura e sociedade; amplia-se o espaço de contingência, na diferenciação estrutural entre sociedade e personalidade; e, por fim, na disjunção entre cultura e personalidade, a renovação da tradição passa a depender "cada vez mais da crítica e da capacidade inovadora dos indivíduos". Em consequência de tudo isso:

(...) a cultura se encontra num estado de permanente revisão de tradições, que se diluem paulatinamente, tornando-se reflexivas; a sociedade entra num estado de dependência de ordens legítimas, de processos formais de criação e fundamentação de normas; e a personalidade passa a ser um estado de estabilização permanente de uma "identidade-eu" autodirigida $^{79}$.

Em resumo, a racionalização do mundo da vida, a que se vincula sua definição estrutural diferenciada, pode ser apreendida numa dialética comunicativa em que, progressivamente, opõe-se à "concordância normativamente prescrita" o "entendimento comunicativamente alcançado". Desse modo, "os contextos da interação passam a depender das condições de um entendimento motivado racionalmente, ou seja, da formação de um consenso respaldado em última instância, no melhor argumento". Renuncia-se, cada vez mais, à aceitação inquestionada dos valores, normas e consensos transmitidos pela tradição. Eles determinam, cada vez menos, um adiantamento de consenso, uma decisão prévia sobre as pretensões de validade que devem prevalecer "e quando, onde, com que fim, por quem e diante de quem" $"$.

78 HABERMAS, Teoria do agir comunicativo, Tomo 01, p. 585 e 586; HABERMAS, Teoria do agir comunicativo, Tomo 02, 2012, p. 265 e 280.

${ }^{79}$ HABERMAS, Teoria do agir comunicativo, Tomo 02, 2012, p. 264 e 265.

${ }^{80}$ HABERMAS, Teoria do agir comunicativo, Tomo 01, 2012, p. 139; HABERMAS, Teoria do agir comunicativo, Tomo 02, 2012, p. 263 e 329. 
Nesse ponto, começa a ser entrevisto o irônico paradoxo da racionalidade, no processo do esclarecimento, descrito por Habermas ${ }^{81}$.

Pois, com a atualização do potencial de racionalidade do entendimento linguístico, a práxis cotidiana se desprende, progressivamente, da eticidade convencional, concreta e heterônoma, dos padrões comportamentais consensuais veiculados e ancorados na tradição ${ }^{82}$. Criam-se, no interior da sociedade, "espaços cada vez mais amplos para o mundo da vida cultural, para a comunicação e entendimento racional entre os homens, para a configuração de sua identidade racional” ${ }^{\prime 83}$.

Ao mesmo tempo, porém, transferido o fardo da integração social, sempre mais, aos processos de formação de consenso no interior da linguagem, a zona do aproblemático diminui. A “crescente pressão de racionalidade, exercida por um mundo da vida problematizado sobre os mecanismos de entendimento, eleva a necessidade de entendimento e, com isso, aumenta o ônus da interpretação e os riscos de dissenso" ${ }^{\text {" }}$.

A carência de entendimento não pode mais ser atendida por aquele acervo de interpretações que, legitimadas na tradição cultural, permaneciam resistentes à crítica, funcionando como "contrapeso conservador que se opõe ao risco de dissenso". E, assim, por fim, o mecanismo "mais arriscado" de entendimento linguístico, cada vez mais exigido e onerado por expectativas de consenso, por demandas sempre maiores de coordenação e por riscos de dissensão, acaba sobrecarregado ${ }^{85}$. Ameaça ruir.

Aqui entra em cena a perspectiva habermasiana da sociedade, influenciada por Luhmann e Parsons, como sistema: a ótica objetivante do observador, impregnada de racionalidade instrumental ${ }^{86}$.

Habermas interpreta a economia capitalista e a estrutura estatal moderna como sistemas parciais de agir teleológico que emergem, diferenciam-se e se autonomizam do mundo da vida, respectivamente, pelos meios de comunicação dinheiro e poder. Trata-se

${ }^{81}$ HABERMAS, Teoria do agir comunicativo, Tomo 01, 2012, p. 590; HABERMAS, Teoria do agir comunicativo, Tomo 02, 2012, p. 280.

${ }^{82}$ HABERMAS, Teoria do agir comunicativo, Tomo 02, 2012, p. 325

${ }^{83}$ SIEBENEICHLER, Jürgen Habermas, 1994, p. 40.

${ }^{84}$ HABERMAS, Teoria do agir comunicativo, Tomo 02, 2012, p. 325 e 330.

${ }^{85}$ HABERMAS, Teoria do agir comunicativo, Tomo 01, 2012, p. 139 e 587; HABERMAS, Teoria do agir comunicativo, Tomo 02, 2012, p. 280.

${ }^{86}$ FREITAG, A teoria crítica, 2004, p. 61; HABERMAS, Teoria do agir comunicativo, Tomo 02, 2012, p. 275 e 277. 
de meios que, destaca o autor, não necessitam mais da linguagem e a substituem enquanto mecanismo de coordenação de ações ${ }^{87}$.

Funcionam, enfim, dinheiro e poder, como mecanismos de desafogo que atenuam os perigos e exigências da interação linguística orientada pelo entendimento ${ }^{88}$.

O processo de racionalização, que conduziu à diferenciação estrutural do mundo da vida, coincide com outro processo: a diferenciação e autonomização sistêmica ${ }^{89}$. Como explica Habermas, a emancipação do agir comunicativo, com a liberação de seu potencial racional e superação da eticidade convencional, significa, também, a disjunção entre o agir orientado pelo entendimento e o agir estratégico, orientado pelo êxito: "Nessa polarização se reflete a separação entre integração social e integração pelo sistema" ${ }^{90}$.

Nos subsistemas economia e administração, diferenciados pelos meios dinheiro e poder, a coordenação da ação é desconectada da formação linguística do consenso, desfazendo-se o liame entre agir social e entendimento. E, nesse processo, perde-se a ancoragem no mundo da vida ${ }^{91}$.

Por fim, na "disjunção entre sistema e mundo da vida", a perspectiva sistêmica volta-se, com efeitos distorcivos, sobre o próprio mundo da vida do qual se desprendeu, "colonizando-o". Mais do que desafogar os riscos e ônus da comunicação, os imperativos sistêmicos impõem-se sobre o mundo da vida, reprimindo e desvirtuando a coordenação social mediada pela linguagem e submetendo a práxis cotidiana ao padrão racional instrumental, ao agir estratégico. Enfim, "O mundo da vida racionalizado possibilita o surgimento e crescimento de certos subsistemas, cujos imperativos, ao se tornarem autônomos, ricocheteiam de modo destrutivo sobre o próprio mundo da vida" ${ }^{92}$.

Tal desvio e deformação patológica não faz Habermas, como visto, recusar as possibilidades da racionalidade, em vista à realização do projeto moderno emancipatório.

${ }^{87}$ HABERMAS, Teoria do agir comunicativo, Tomo 01, 2012, p. 588 e 589; HABERMAS, Teoria do agir comunicativo, Tomo 02, 2012, p. 278, 280, 326, 327, 330 e 576.

${ }^{88}$ HABERMAS, Teoria do agir comunicativo, Tomo 02, 2012, p. 327 e 330.

89 HABERMAS, Teoria do agir comunicativo, Tomo 01, 2012, p. 588; HABERMAS, Teoria do agir comunicativo, Tomo 02, 2012, p. 275 e 277; PINZANI, Habermas, 2009, p. 110.

${ }^{90}$ HABERMAS, Teoria do agir comunicativo, Tomo 02, 2012, p. 326; PINZANI, Habermas, 2009, p. 110 e 111.

91 HABERMAS, Teoria do agir comunicativo, Tomo 01, 2012, p. 590; HABERMAS, Teoria do agir comunicativo, Tomo 02, 2012, p. 280, 281, 330 e 331; BITTAR, Justiça e emancipação, 2011, p. 338.

92 HABERMAS, Teoria do agir comunicativo, Tomo 02, 2012, p. 281, 334, 336, 354, 355, 552, 575 e 576. 
Tampouco negar sua dimensão instrumental. Afinal, não desmerece, absolutamente, os progressos materiais que seu desempenho proporcionou à humanidade ${ }^{93}$.

Descartando, porém, a identificação da emancipação, sem mais, com o progresso da ciência e da técnica ${ }^{94}$, refere-a à reativação do potencial da racionalidade comunicativa, revelado na própria modernidade: "Somente essa racionalidade comunicativa, que se reflete na autocompreensão da modernidade, confere uma lógica interna à resistência contra a mediatização do mundo da vida provocada pela dinâmica própria dos sistemas que se tornaram autônomos" $" 95$.

A emancipação passa, assim, pela descolonização do mundo da vida, como “mecanismo reativo necessário para o processo de recuperação das formas comunicativas de interação que definem o modo de operar do mundo da vida"96

Com isso, Habermas pode destacar, na modernidade, duas experiências racionais fundamentais que, não obstante todos os retrocessos e descaminhos verificados, não devem ser abandonadas. De um lado, "a competência técnica e instrumental, desenvolvida pelos sistemas de reprodução material, graças à ciência e à técnica"97. De outro, a racionalização do mundo da vida ao nível em que a práxis discursiva representa o mecanismo de coordenação da ação, frente a um cenário pós-metafísico, em que as tradições, a religião não resistem mais, como fonte hermenêutica que legitima e adianta interpretações situacionais e o direcionamento da interação social ${ }^{98}$.

A descolonização referida implica, nesse contexto, o resgate do terreno perdido pela razão comunicativa, privilegiando o entendimento no mundo da vida racionalizado, como espaço definidor da manutenção da sociedade como um todo. E isso, sem negar a perspectiva sistêmica. Apenas recolocando a razão instrumental em seu devido lugar, a

${ }^{93}$ FREITAG, A teoria crítica, 2004, p. 64; NOBRE, Luta por reconhecimento: Axel Honneth e a teoria crítica, 2009, p. 12; PINZANI, Habermas, 2009, p. 77; BITTAR, Justiça e emancipação, 2011, p. 350.

${ }^{94}$ HABERMAS, Teoría y praxis, 1990 , p. 314 e 324.

${ }^{95}$ HABERMAS, Teoria do agir comunicativo, Tomo 02, 2012, p. 601.

${ }^{96}$ BITTAR, Justiça e emancipação, 2011, p. 350.

${ }^{97}$ FREITAG, A teoria crítica, 2004, p. 64.

98 HABERMAS, Consciência moral e agir comunicativo, 2003, p. 169; HABERMAS, Teoria do agir comunicativo, Tomo 01, 2012, p. 138, 139 e 587; HABERMAS, Teoria do agir comunicativo, Tomo 02, 2012, p. 329. 
saber, a reprodução do substrato material, de qualquer modo referida, entrelaçada e, principalmente, determinada pelos processos linguísticos orientados ao entendimento ${ }^{99}$.

1.4. Sendo assim, o resgate da comunicação orientada ao entendimento aparece, em Habermas, como a alternativa - ou, ainda, reviravolta - racional emancipatória ao processo histórico em que, paradoxalmente, a racionalização empobreceu e desativou o discurso.

O discurso a que remete a razão comunicativa e que dá continuidade, de modo reflexivo, à ação orientada ao entendimento, traz consigo dois imensos potenciais, também assimilados, como já descrito, na filosofia deweyana. Primeiro, o sentido cognitivo de "filtrar contribuições e temas, argumentos e informações, de tal modo que os resultados obtidos por este caminho têm a seu favor a suposição da aceitabilidade racional”. Segundo, o sentido prático, de produzir relações de entendimento, isentas de violência ${ }^{100}$.

Há, nesse sentido, uma promessa cognitiva vinculada à comunicação linguística, que, no pragmatismo norte-americano, efetiva-se na fórmula da pesquisa cooperativa da verdade. É ínsito ao discurso o significado de aprendizado mútuo. Na contradição de perspectivas e visões de mundo, os horizontes de sentido se ampliam e se imbricam cada vez mais, explodindo as limitações experienciais e superando particularismos semânticos ${ }^{101}$.

Em virtude da "possibilidade de serem criticadas", as pretensões de validade, contidas na fala e na ação racional, são, ao mesmo tempo, "passíveis de correção". Por isso, ao conceito de argumentação e, nele, de fundamentação, num ambiente livre de coações e violência, liga-se, intimamente, a ideia de aprendizado:

As argumentações tornam possível um comportamento considerado racional em um sentido peculiar, qual seja o aprendizado a partir de erros explícitos (...) os processos de aprendizado dependem de argumentações; e é por meio destes últimos que angariamos conhecimentos teóricos e

99 HABERMAS, Teoría y praxis, 1990, p. 327, 328 e 334; HABERMAS, O discurso filosófico da modernidade, 2002, p. 446; HABERMAS, Teoria do agir comunicativo, Tomo 02, 2012, p. 253, 278 e 334 ; BOUFLEUER, Pedagogia da ação comunicativa, 2001, p. 90; FREITAG, A teoria crítica, 2004, p. 63.

${ }^{100}$ HABERMAS, Direito e democracia, Vol. 01, 2012, p. 190 e 191.

101 BERNSTEIN, The resurgence of pragmatism, 1992, p. 814; JOAS, Hans. Pragmatism and social theory. Chicago: University of Chicago Press, 1993, p. 19; HABERMAS, Verdade e justificação, 2009, p. 71 e 95. 
discernimentos morais, renovamos e ampliamos a linguagem avaliativa e suplantamos autoenganos e dificuldades de entendimento ${ }^{102}$.

Ao lado do discurso teórico, em que são tematizadas pretensões de verdade controversas, sobre algo no mundo objetivo, Habermas destaca o discurso prático, "a forma de argumentação que permite tematizar pretensões à correção normativa" ${ }^{\text {"103 }}$, tematização que, explica, "não é diversa da que tem lugar no caso das questões de verdade". Nos discursos, "assim como os fatos se transformam em 'estados de coisas' que podem ser ou não o caso, assim também as normas habitualizadas socialmente transformam-se em possibilidades de regulação que podem aceitar como válidas ou recusar como inválidas" 104 .

Isso não implica, absolutamente, confusão entre os distintos mundos e pretensões sobre os quais incide cada um desses tipos discursivos. Não há dúvida,

A objetividade do protesto de um outro espírito é feita de um material diferente do que compõe a objetividade de uma realidade surpreendente. Não é a contingência cega das circunstâncias decepcionantes que assinala o fracasso dos juízos e normas morais, mas antes a dor dos ofendidos, cuja voz se faz ouvir na contradição e na indignação dos adversários que esposam orientações de valor diferentes ${ }^{105}$.

Enfim, o que se tira disso tudo é que, pressuposto o potencial racional das manifestações e questões prático-morais, as pretensões de validade "ligadas a normas de ação e sobre as quais os mandamentos e as frases com sentido deôntico se apoiam" podem, também, ser resgatadas discursivamente e decididas com base em boas razões ${ }^{106}$.

Assim, a filosofia habermasiana trabalha a questão da moralidade, de modo "independente das suposições da metafísica e da religião"107, dentro de uma perspectiva procedimental (formal) e cognitivista, preservando, na comunicação, a pretensão de unidade e universalidade da razão. Tal é a aposta da ética do Discurso: uma ética da interação linguística, pelo medium do discurso ${ }^{108}$.

102 HABERMAS, Teoria do agir comunicativo, Tomo 01, 2012, p. 49 e 57.

${ }^{103}$ HABERMAS, Teoria do agir comunicativo, Tomo 01, 2012, p. 49 e 50.

${ }^{104}$ HABERMAS, Consciência moral e agir comunicativo, 2003, p. 155.

${ }^{105}$ HABERMAS, Jürgen. A ética da discussão e a questão da verdade. Organização e introdução de Patrick Savidan. Trad. Marcelo Brandão Cipolla. 2ª ed. São Paulo: Martins Fontes, 2007, p. 66.

${ }^{106}$ HABERMAS, Teoria do agir comunicativo, Tomo 01, 2012, p. 49 e 50.

${ }^{107}$ HABERMAS, Consciência moral e agir comunicativo, 2003, p. 61.

${ }^{108}$ BITTAR, Justiça e emancipação, 2011, p. 277 e 288; PINZANI, Habermas, 2009, p. 125; FREITAG, Bárbara. A questão da moralidade: da razão prática de Kant à ética discursiva de Habermas. Tempo social. Revista de Sociologia da USP. Volume 01, $\mathrm{n}^{\circ}$ 02, São Paulo, $2^{\underline{0}}$ semestre de 1989, p. 36; HABERMAS, Teoria do agir comunicativo, Tomo 01, 2012, p. 51; HABERMAS, Jürgen. Escritos sobre moralidad y eticidad. Barcelona: Paidós/Universidad Autónoma de Barcelona, 1991, p. 101 e 102. 
$\mathrm{Na}$ ética discursiva, o critério último da moralidade radica no "processo argumentativo desencadeado pelo discurso prático"109 . O lugar antes ocupado, em Kant, pelo imperativo categórico - "Age apenas segundo uma máxima tal que possas ao mesmo tempo querer que ela se torne lei universal" $" 110$ - passa ao procedimento de $\operatorname{argumentação}^{111}$. É nele que se atualiza a ideia de autonomia moral.

Daí, Habermas estabelece o princípio do discurso, ao qual pode ser resumida sua filosofia moral: "somente podem pretender validade aquelas normas que possam contar com o assentimento de todos os atingidos, enquanto participantes de um discurso prático" $" 112$. O princípio, assim, "submete a validade de qualquer tipo de norma de ação ao assentimento daqueles que, na qualidade de atingidos, tomam parte em 'discursos racionais $", 113$.

Quanto ao imperativo categórico, perde seu status de um critério moral absoluto, aprioristicamente a disposição de uma razão prática "pura". Transmuda-se à condição de um princípio da universalização que funciona como regra de argumentação para a decisão racional, no âmbito de discursos prático-morais ${ }^{114}$. De acordo com ele, "os resultados e efeitos colaterais que, para a satisfação dos interesses de cada um, previsivelmente decorram da observância geral da norma, tem de poder ser aceitos sem coação nenhuma, por todos" $" 115$.

Como esclarece Habermas, os dois princípios não se confundem ${ }^{116}$. O princípio da universalização "se limita a dizer quando uma norma é capaz de obter consenso; ele afirma com isso, quais são as condições para tal consenso". Já o do discurso, "afirma que uma

\footnotetext{
${ }^{109}$ FREITAG, A questão da moralidade, 1989, p. 36.

${ }^{110}$ KANT, Immanuel. Fundamentação da metafísica dos costumes. Trad. Paulo Quintela. Lisboa:Edições 70, 2008 , p. 62.

${ }^{111}$ FREITAG, A questão da moralidade, 1989, p. 36; HABERMAS, Escritos sobre moralidad y eticidad, 1991, p. 101.

${ }^{112}$ HABERMAS, Escritos sobre moralidad y eticidad, 1991, p. 101; HABERMAS, Consciência moral e agir comunicativo, 2003, p. 86 e 116.

${ }^{113}$ HABERMAS, Direito e democracia, Vol. 01, 2012, p. 142 e 199.

114 FREITAG, A questão da moralidade, 1989, p. 08 e 36; HABERMAS, Escritos sobre moralidad y eticidad, 1991, p. 101; HABERMAS, Direito e democracia, Vol. 01, 2012, p. 144 e 145.

${ }^{115}$ HABERMAS, Escritos sobre moralidad y eticidad, 1991, p. 101 e 102; HABERMAS, Consciência moral e agir comunicativo, 2003, p. 86, 116 e 147.

${ }^{116}$ HABERMAS, Consciência moral e agir comunicativo, 2003, p. 86 e 116.
} 
norma deve obter consenso de todos os concernidos; ele possui, portanto, caráter normativo" 117 .

A ética discursiva implica, desse modo, uma interpretação e aplicação intersubjetivista do imperativo categórico, que "não se esgota numa reflexão monológica segundo a qual determinadas máximas seriam aceitáveis como leis universais do meu ponto de vista"118. Citando McCarthy:

(...) ao invés de prescrever a todos os demais como válida uma máxima que eu quero que seja uma lei universal, tenho que apresentar minha máxima a todos os demais envolvidos no exame discursivo de sua pretensão de universalidade. $O$ peso desloca-se daquilo que cada (indivíduo) pode querer sem contradição como lei universal para aquilo que todos querem de comum acordo reconhecer como norma universal ${ }^{119}$.

As normas de ação, na medida em que pretendem exteriorizar um "interesse comum a todos os atingidos" - e, dessa forma, merecer reconhecimento geral -, devem, no âmbito do discurso prático e, nele, ponderados os interesses envolvidos assim como analisadas as consequências e os efeitos colaterais que previsivelmente resultam de sua aplicação, encontrar o assentimento racional dos atingidos ${ }^{120}$.

No âmbito das normas propriamente morais isso vai remeter a uma pretensão de universalidade, que se desprende, no final das contas, da eticidade concreta de um dado grupo social, demarcada no horizonte de um mundo da vida ${ }^{121}$. Nesse ponto, é importe destacar a distinção, apresentada por Habermas, entre o discurso prático moral e o ético.

Este último, explica o autor, efetiva-se no interior das tradições, orientações axiológicas, perspectivas e fins que marcam a identidade de uma determinada coletividade, inseridas em seu mundo da vida. Remetem a questões do "bem viver", dos modos de agir "bons para nós”, justificados no âmbito da autocompreensão de uma comunidade histórica, delimitada por uma forma de vida concreta, para fora da qual os participantes da

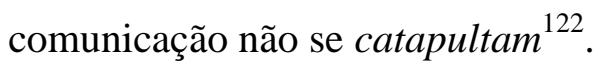

\footnotetext{
${ }^{117}$ PINZANI, Habermas, 2009, p. 132.

${ }^{118}$ HABERMAS, A ética da discussão e a questão da verdade, 2007, p. 08 a 10.

${ }^{119}$ HABERMAS, Consciência moral e agir comunicativo, 2003, p. 88.

${ }^{120}$ FREITAG, A questão da moralidade, 1989, p. 36; HABERMAS, Consciência moral e agir comunicativo, 2003, p. 86; HABERMAS, Teoria do agir comunicativo, Tomo 01, 2012, p. 50.

${ }^{121}$ HABERMAS, Consciência moral e agir comunicativo, 2003, p. 126 e 131; HABERMAS, Direito e democracia, Vol. 01, 2012, p. 193 e 205.

122 HABERMAS, Consciência moral e agir comunicativo, 2003, p. 131; HABERMAS, Direito $e$ democracia, Vol. 01, 2012, p. 199, 201, 202 e 205.
} 
Já o discurso prático-moral, amparado no princípio da universalização, induz a formação imparcial do juízo, ou ainda, um acordo sobre uma norma que atende ao interesse simétrico de todos, para além do meu ou do nosso interesse. Referido a um círculo ilimitado de destinatários, elimina, "a título de conteúdos não passíveis de universalização", aquelas orientações axiológicas entrelaçadas e circunscritas a formas de vida particular ou a histórias de vida particular ${ }^{123}$.

Para isso, fazendo referência ao pensamento de Mead e Piaget, Habermas afirma que cumpre aos participantes do discurso moral a assunção ideal da posição e da perspectiva de todos os outros, o que lhes assegura a “progressiva 'descentralização' da compreensão egocêntrica e etnocêntrica que cada qual tem de si mesmo e do mundo"124:

(...) a perspectiva etnocentrista de uma determinada coletividade se alarga, assumindo a perspectiva abrangente de uma comunidade comunicativa não circunscrita, onde cada membro se coloca na situação, na compreensão e na autocompreensão do mundo de cada um dos outros ${ }^{125}$.

Sendo assim, o caráter procedimental formalista da moral habermasiana não significa, absolutamente, o alheamento a conteúdos: "Formal, por conseguinte, esse procedimento não o é no sentido de abstração de conteúdos". Implica, somente, a abdicação e, mais, a proibição de que se privilegiem e se fixem, em detrimento de outros e de uma vez por todas, determinados conteúdos morais ${ }^{126}$. Como pensamento pósmetafísico, "recusa a afirmação de conteúdos que possam estar além do tempo, do espaço, das condições sociais da comunidade que pretende ver uma norma ser inscrita como revelação da ideia de justiça"127.

Rechaçada a autoridade apriorística de qualquer julgamento ou orientação conteudista, "Todos os conteúdos, mesmo os concernentes a normas de ação não importa quão fundamentais estas sejam, têm de ser colocados na dependência de Discursos reais" ${ }^{128}$.

${ }^{123}$ HABERMAS, Consciência moral e agir comunicativo, 2003, p. 86 e 148; HABERMAS, A ética da discussão e a questão da verdade, 2007, p. 10; HABERMAS, Direito e democracia, Vol. 01, 2012, p. 191 e 199.

${ }^{124}$ HABERMAS, Consciência moral e agir comunicativo, 2003, p. 86; HABERMAS, A ética da discussão e a questão da verdade, 2007, p. 10.

${ }^{125}$ HABERMAS, Direito e democracia, Vol. 01, 2012, p. 203.

${ }^{126}$ HABERMAS, Consciência moral e agir comunicativo, 2003, p. 117 e 149.

${ }^{127}$ BITTAR, Justiça e emancipação, 2011, p. 266.

${ }^{128}$ HABERMAS, Consciência moral e agir comunicativo, 2003, p. 149. 
Nesse sentido, evidentemente, também as normas morais incorporarão interesses e valores. Porém, apenas na medida em que são generalizáveis e expressem, de modo fundamentado, no âmbito da argumentação, “o que é igualmente bom para todos”, no universo não circunscrito de destinatários. Elas se destacam do conjunto de conteúdos contingentes (candidatos a normas que representam um interesse universal) que dão início ao discurso prático - e sem os quais não faria sentido o empreendimento discursivo. Distinguem-se das perspectivas axiológicas e teleológicas particulares ${ }^{129}$.

Ao afirmar a validez deontológica da moral, a ética discursiva exclui "a interpretação que leva em conta a vantagem relativa de certos valores ou interesses". Demarca "o domínio do moralmente válido em face do domínio dos conteúdos de valor cultural"130.

De qualquer forma, porque os participantes da comunicação estão inseridos no mundo da vida, que lhes molda o olhar, fornecendo os recursos para os processos de atribuição de sentido, é evidente a dialética permanente envolvida no discurso moral: um processo racional falível e contínuo de busca da universalidade a partir da particularidade.

Esvaziada "da pretensão de oferecer um conteúdo, uma semântica, uma substância"131 a ética discursiva habermasiana detém-se à indicação de um processo: o discurso prático, "rico de pressupostos, que deve garantir a imparcialidade da formação do juízo" ${ }^{\text {132 }}$. Eis o lugar da autonomia moral.

Para tanto, porém, é pressuposto o cumprimento de requisitos bastante exigentes. Além da existência de uma linguagem comum, o discurso demanda, numa relação de enriquecimento recíproco, uma situação dialogal "ideal", livre de coações e violência, e a competência e disposição comunicativa dos participantes da comunicação ${ }^{133}$ :

\footnotetext{
129 HABERMAS, Consciência moral e agir comunicativo, 2003, p. 117; HABERMAS, Direito $e$ democracia, Vol. 01, 2012, p. 193.

${ }^{130}$ HABERMAS, Consciência moral e agir comunicativo, 2003, p. 127 e 148; HABERMAS, Direito $e$ democracia, Vol. 01, 2012, p. 193.

${ }^{131}$ BITTAR, Justiça e emancipação, 2011, p. 288.

${ }^{132}$ HABERMAS, Consciência moral e agir comunicativo, 2003, p. 126 e 148.

${ }^{133}$ FREITAG, A questão da moralidade, 1989, p. 37.
} 
i) Em relação ao ambiente em que se efetiva o discurso, Habermas fala de uma situação ideal de fala que corresponde, em última análise, às “condições gerais de simetria que todo falante competente precisa supor suficientemente satisfeitas, tão logo ele pense em tomar parte de uma argumentação". Corresponde a uma estrutura comunicativa que assegura iguais chances de participação, sem qualquer repressão, e que, desse modo, "exclui toda a coação (quer ela atue a partir de fora sobre o processo de entendimento, quer se origine nele), exceto a coerção do melhor argumento (o que implica também a desativação de todos os motivos, exceto a procura cooperante da verdade)"134.

Trata-se de um contexto de fala que, de fato, vê-se ameaçado diante da realidade histórico-social. Nos descaminhos da modernidade, lembra Habermas, as argumentações voltadas ao entendimento assemelham-se, muito mais, a "ilhas ameaçadas de se verem submersas pelas ondas no oceano de uma prática onde o modelo da solução consensual dos conflitos de ação não é de modo algum dominante (...) não cessam de se ver desalojados pelos instrumentos da violência"135.

Isso não implica, contudo, negar sua possibilidade, sua prática e sua potencialidade. A situação dialogal "ideal" não indica, absolutamente, uma mera abstração teórica infundada $^{136}$. Com efeito, o entendimento permanece presente nas práticas cotidianas, imersas no mundo da vida, em que se efetivam argumentações, nas quais ninguém ingressa "sem se apoiar intuitivamente numa forte pressuposição, a saber, que é possível chegar, em princípio, a um consenso fundamentado" ${ }^{\text {137. }}$.

A tensão entre o real e o ideal, sem dúvida, é constante. De um lado, “os participantes da argumentação não têm outra saída senão partir da pressuposição (frequentemente contrafactual) de que se cumpriram, em aproximação satisfatória, as condições de uma situação ideal de fala”. Por outro, sabem que o discurso nunca será absolutamente purificado "de motivos ocultos e de pressões sobre a ação". De tudo isso, fica a pertinente advertência habermasiana de que "quanto menos supormos um discurso purificado, tanto mais teremos de nos contentar com o discurso "contaminado",138.

\footnotetext{
${ }^{134}$ HABERMAS, Teoria do agir comunicativo, Tomo 01, 2012, p. 60 e 61; HABERMAS, Consciência moral e agir comunicativo, 2003, p. 111 e 112.

${ }^{135}$ HABERMAS, Consciência moral e agir comunicativo, 2003, p. 128.

${ }^{136}$ FREITAG, A questão da moralidade, 1989, p. 37 e 39.

${ }^{137}$ HABERMAS, Teoria do agir comunicativo, Tomo 01, 2012, p. 50.

138 HABERMAS, O discurso filosófico da modernidade, 2002, p. 449; HABERMAS, Teoria do agir comunicativo, Tomo 01, 2012, p. 91.
} 
Esse é, afinal, o modelo estrutural de comunicação que, para Habermas, constitui o "único mecanismo de auto-organização que se encontra à disposição da comunidade. Por esse caminho, ela deve superar todos os conflitos sem o emprego da violência”. ${ }^{139}$.

ii) Ao mesmo tempo, o discurso pressupõe a competência e a disposição comunicativa dos atores sociais. Isto é, implica a constituição racional da personalidade, no sentido de que o sujeito é capaz de agir e falar, em condições de participar de argumentações, voltadas ao entendimento. Isto é, de que se orienta por pretensões de validade, das quais pode prestar contas, se necessário, no âmbito do discurso ${ }^{140}$.

Corresponde, nessa linha, ao desenvolvimento do sujeito de modo a atingir o estágio pós-convencional (autônomo) do juízo moral. Aqui, conforme analisado detidamente logo abaixo, o sujeito já dispõe de estruturas cognitivas que lhe permitem um olhar distanciado e, desse modo, uma atitude hipotética frente ao seu mundo social, passível de crítica quanto a sua pretensão de validade e carecedor de justificação. Na oposição entre eticidade e moralidade, entre facticidade e validade (legitimidade) das normas sociais, o sujeito guarda consigo, como critério moral, o discurso prático de fundamentação das normas de ação ${ }^{141}$.

Mas não é só isso. À competência comunicativa vincula-se o hábito, a disposição para ingressar na argumentação, fazendo uso da liberdade comunicativa.

Por liberdade comunicativa, Habermas entende a "possibilidade - pressuposta no agir que se orienta pelo entendimento - de tomar posição frente aos proferimentos de um oponente e às pretensões de validade aí levantadas, que dependem de um reconhecimento intersubjetivo". Atualiza-se, sempre, como na filosofia deweyana, no âmbito de uma relação intersubjetiva, "entre atores que desejam entender-se entre si", contando, para tanto, “com tomadas de posição perante pretensões de validade reciprocamente levantadas" 142 .

Porém, como tratado anteriormente, o sujeito capaz de falar e agir, que pode se distanciar do acervo de valores tradicionais, interpretações e certezas que integram seu

\footnotetext{
${ }^{139}$ HABERMAS, Direito e democracia, Vol. 02, 2011, p. 51.

140 HABERMAS, Verdade e justificação, 2009, p. 102; HABERMAS, Teoria do agir comunicativo, Tomo 02, 2012, p. 253.

${ }^{141}$ HABERMAS, Consciência moral e agir comunicativo, 2003, p. 156, 199 e 212.

${ }^{142}$ HABERMAS, Direito e democracia, Vol. 01, 2012, p. 155 e 156.
} 
mundo da vida, pode, também, "abandonar a qualquer momento a orientação pelo entendimento, adotando um enfoque estratégico e objetivando contextos normativos como algo no mundo objetivo"143.

A liberdade do sujeito, enfim, apresenta outro aspecto. Permite, mesmo, a saída da esfera do agir comunicativo, autolibertando-se do peso da liberdade comunicativa. Como destaca Habermas, vai tão longe que o sujeito, adotando uma posição estratégica, não precisa prestar contas, ou ainda, apresentar boas razões para seus planos de ação ${ }^{144}$.

A competência comunicativa imbrica-se, nesse sentido, com a disposição ao diálogo, em que fins ilocucionários são perseguidos sem reservas, fazendo-se uso da liberdade comunicativa e, por conseguinte, liberando-se o potencial de racionalidade embutido no agir comunicativo. Sem tal referência, decai ao uso parasitário da linguagem, no âmbito da conformação desfigurada da razão, restrita à dimensão instrumental, e, nessa extensão, do agir egocentricamente guiado.

1.5. A competência e disposição do sujeito ao discurso prático, indicativa de sua racionalidade comunicativa, é resultado, para Habermas, de um processo bem sucedido de desenvolvimento moral.

Revisitando os estudos de Mead, Piaget e Kohlberg - e, desse modo, com aproximações significativas à teoria moral deweyana - 0 autor apresenta o desenvolvimento da consciência moral como um processo de aprendizagem, efetivado, por estágios, na direção da autonomia.

E isso de par com o desenvolvimento cognitivo, ou seja, a construção linguística, pelo sujeito em crescimento, de seu universo interno, o mundo subjetivo, e, dele apartado, do universo externo, diferenciado num mundo objetivo, dos objetos perceptíveis e manipuláveis, e um mundo social, de relações intersubjetivas ${ }^{145}$. A partir das experiências com objetos físicos e com outras pessoas, o sujeito "não somente constrói e reconstrói seu

143 HABERMAS, Consciência moral e agir comunicativo, 2003, p. 212; HABERMAS, Teoria do agir comunicativo, Tomo 02, 2012, p. 279.

${ }^{144}$ HABERMAS, Direito e democracia, Vol. 01, 2012, p. 156.

${ }^{145}$ HABERMAS, Teoria do agir comunicativo, Tomo 01, 2012, p. 136 e 137. 
conhecimento da natureza e da sociedade, mas elabora, na descoberta desses mundos e na ação e interação com eles, seus instrumentos de pensamento" ${ }^{\text {"146. }}$.

O desenvolvimento moral cognitivista, nessa medida, atualizado no âmbito da constituição da individualidade na socialização, significa que, no enfrentamento e solução de problemas de coordenação da ação, a pessoa em crescimento vai reconstruindo continuamente seus recursos e estruturas racionais, que subjazem à faculdade de julgar. $\mathrm{E}$ pode, dessa forma, resolvê-los de forma melhor do que antes, percebendo em que medida os juízos que antes considerava corretos, perderam sua validade ${ }^{147}$.

As estruturas e os instrumentos do pensamento, dessa forma, são apreendidos como o resultado da reorganização criativa de um inventário cognitivo preexistente, sobrecarregado por problemas morais, num contínuo processo construtivista de aprendizagem $^{148}$.

Redefinindo, validando e aprimorando a acepção teórica de crescimento moral, proposta por Dewey, e, ainda, as pesquisas empíricas sobre o julgamento moral da criança, conduzidas por Piaget, Kohlberg concebe referido processo de desenvolvimento num percurso que abrange, também, três níveis de percepção, pelo sujeito em formação, das normas sociais (pré-convencional, convencional e pós-convencional). Subdivide, ainda, cada um deles, em dois estágios. Tudo isso, numa sequência invariante, para frente, sem saltos, em que "Pensar em um estágio superior requer pensar em um estágio inferior"149.

Resumidamente, explica Kohlberg, no nível pré-convencional, a criança ainda não apreende o caráter convencional da norma, aceitando-a como um fato da natureza ou uma ordem de uma autoridade, de qualquer modo fora de sua consciência. Divide-o em dois estágios: o primeiro, da orientação por castigo e obediência e o segundo, da orientação instrumental hedonista, quando a ação é correta na medida em que atenda instrumentalmente às necessidades do $\mathrm{Eu} \mathrm{e}$, ocasionalmente, a dos outros. $\mathrm{O}$ nível convencional é aquele em que o caráter convencional da regra é reconhecido e respeitado.

\footnotetext{
${ }^{146}$ FREITAG, A questão da moralidade, 1989, p. 13.

${ }^{147}$ HABERMAS, Consciência moral e agir comunicativo, 2003, p. 154 e 155.

${ }^{148}$ HABERMAS, Consciência moral e agir comunicativo, 2003, p. 155.

${ }^{149}$ FREITAG, A questão da moralidade, 1989, p. 14; KOHLBERG, Lawrence. La democracia en la escuela secundaria: educando para una sociedad mas justa. Trad. Maria Mercedes Oraison. Chaco: Universidad Nacional del Nordeste, 1992, p. 03 a 05.
} 
Aqui, aparecem o terceiro estágio, da orientação pelo ideal estereotipado de bom menino, boa menina e o quarto, da orientação pela ideia de lei e ordem, em que a conduta correta implica o cumprimento do dever e o respeito à ordem e à autoridade, enquanto tais. No nível pós-convencional, o sujeito já abstrai do caráter convencional das normas habitualmente praticadas, orientando-se por valores e princípios com validade à margem da autoridade do grupo e da identificação com ele. Subdivide-se, para Kohlberg, no quinto estágio, da orientação contratual-legalista, em que as normas sociais são compreendidas como convenção flexível, relativa, acordada e passível de correção pelo grupo. A obrigação é definida em termos de um contrato, um livre acordo, superando a inflexibilidade e objetividade da perspectiva anterior da "lei e ordem". Por fim, o sexto estágio, da orientação por princípios éticos universais e abstratos, de justiça, reciprocidade, igualdade de direitos humanos e respeito à dignidade humana ${ }^{150}$.

Para Habermas, tal conceito de desenvolvimento moral cognitivista ajusta-se à sua proposta de ética discursiva. Revisita-o, então, para compreendê-lo no âmbito de um modelo comunicativo que, indiretamente referido à Dewey, abrange os estágios de interação pré-convencional, convencional (heterônomo) e, finalmente, abrindo-se ao discurso, pós-convencional (autônomo) ${ }^{151}$.

Desse modo, num processo de formação da individualidade na socialização, o sujeito em crescimento pode ingressar heteronomamente no mundo social, para, finalmente, na continuidade da reconstrução de seus instrumentais e recursos cognitivos, atualizar a mudança de atitude, indispensável à práxis discursiva, em que assume uma atitude hipotética em face de seu contexto social normativo ${ }^{152}$.

A passagem ao plano pós-convencional do juízo moral é resumida, por Habermas, a partir de experiência imaginária em que condensa a fase de adolescência num "momento único crítico". Nele, adotada pelo adolescente, de modo totalizante, aludida atitude hipotética, "De um só golpe, o mundo social das relações interpessoais legitimamente reguladas - mundo esse ingenuamente habitualizado e reconhecido sem problemas - se vê

\footnotetext{
${ }^{150}$ FREITAG, A questão da moralidade, 1989, p. 3230, 31 e 33; KOHLBERG, La democracia en la escuela secundaria, 1992, p. 06 a 08; BITTAR, Justiça e Emancipação, 2011, p. 240 a 243.

${ }^{151}$ HABERMAS, Consciência moral e agir comunicativo, 2003, p. 164 e 193.

152 HABERMAS, Consciência moral e agir comunicativo, 2003, p. 155; HABERMAS, Teoria do agir comunicativo, Tomo 02, 2012, p. 47.
} 
desenraizado e despido de sua validade nativa". Diante disso, haja vista que não pode e não quer se contentar com o "tradicionalismo" e com a "identidade inquestionada" do contexto do qual emergiu, o sujeito em crescimento tem que, a partir dos "destroços das tradições desvalorizadas e devassadas como meras convenções carentes de justificação", reconstruir, discursivamente, a esfera normativa desintegrada "diante da força desveladora de seu olhar hipotético". E isso de forma tal que:

(...) o novo edifício possa resistir ao olhar crítico de uma pessoa que perdeu suas ilusões e que, de agora em diante, não pode mais fazer outra coisa senão distinguir entre normas em vigor numa sociedade e normas válidas, entre as que são de fato reconhecidas e as que são dignas de reconhecimento ${ }^{153}$.

No desenrolar desse processo de aprendizagem, o juízo moral desprende-se dos conteúdos preditos e imersos na eticidade concreta do mundo da vida. Revigora-se procedimentalmente, a partir da práxis argumentativa, na qual a pretensão de validade de tais conteúdos, passível de crítica, deve ser racionalmente fundamentada ${ }^{154}$.

Os estágios de interação que, abrangidos no percurso do desenvolvimento da consciência moral, culminam nessa passagem do "agir guiado por regras para o Discurso destinado ao exame das normas", são assim descritos por Habermas:

i) No estágio pré-convencional, o avanço significativo consiste em que a criança já distingue do mundo exterior não apenas o mundo interior próprio como o dos outros. Pode, nessa medida, "sair mentalmente fora de si e adotar uma perspectiva autorreflexiva ou na segunda pessoa", percebendo que o outro fará o mesmo. Assim, os papéis de primeira e segunda pessoa, as perspectivas eu-tu do falante e do ouvinte, vinculadas de maneira reversível, permitem já a coordenação da ação. Isso, porém, num contexto relacional de "relativo isolamento", sob o olhar da criança: "dois indivíduos particulares vendo a si mesmo e o outro, mas não o sistema de relações entre eles"155.

Habermas distingue, nesse estágio, interações interpretadas pela criança como simétricas - em que, ante a distribuição igualitária de poder, ela pode interferir e contribuir

\footnotetext{
${ }^{153}$ HABERMAS, Consciência moral e agir comunicativo, 2003, p. 155 e 156.

${ }^{154}$ HABERMAS, Consciência moral e agir comunicativo, 2003, p. 156.

155 HABERMAS, Consciência moral e agir comunicativo, 2003, p. 176, 177, 179; HABERMAS, Teoria do agir comunicativo, Tomo 01, 2012, p. 137.
} 
em seu direcionamento, se necessário, mediante manobras para enganar - e a interação governada por autoridade. Aqui, as expectativas e os padrões imperativos de comportamento são referidos e vinculados a pessoas de referência concretas, singulares (o pai, a mãe, a pessoa mais velha em geral). E são experimentados como "algo externo, atrás do qual se esconde a autoridade da pessoa de referência". A coordenação da ação baseiase na força reguladora da autoridade, de modo que a criança tenta resolver o eventual conflito entre suas necessidades e as imposições imperativas, evitando o castigo, as sanções ameaçadas ${ }^{156}$.

ii) No estágio convencional, o sujeito em crescimento adquire a habilidade de assumir a perspectiva de terceira pessoa, de modo que pode objetualizar a interação entre os comunicantes, da qual é integrante, e - para além da dualidade do estágio préconvencional - trazê-la à consciência dentro uma totalidade, um sistema de relações. Isto é, “o entrelaçamento recíproco das orientações de ação da primeira e segunda pessoa pode ser compreendido enquanto tal a partir da perspectiva de uma terceira pessoa", do observador $^{157}$.

No processo de socialização, os padrões e expectativas de comportamento vão se desvinculando, tornando-se independentes do poder de sanção da pessoa concreta de referência e da interação específica em que atualizados. Internalizadas, isto é, integradas à personalidade em formação, assumem a figura de normas sociais, expectativas de comportamento generalizadas a que $e u$ e $t u$ estão submetidos ${ }^{158}$.

A criança internaliza e ancora a violência, a imposição das instituições e das expectativas comportamentais em seu próprio $\mathrm{eu}$, como um sistema interno de controle de comportamento (superego). Passa a considerar "as sanções do grupo como suas próprias sanções, dirigidas por ele mesmo contra si mesmo", pressupondo "seu assentimento em relação à norma, cuja infração ele penaliza dessa forma”. A autoridade imperativista tornase normativa. Nesse horizonte, as expectativas de comportamento, as normas e sanções passam a compor um mundo social de relações legitimamente ordenadas, do qual falante e

\footnotetext{
156 HABERMAS, Consciência moral e agir comunicativo, 2003, p. 181, 182, 186 e 188; HABERMAS, Teoria do agir comunicativo, Tomo 02, 2012, p. 65.

${ }^{157}$ HABERMAS, Consciência moral e agir comunicativo, 2003, p. 177, 180 e 192.

158 HABERMAS, Consciência moral e agir comunicativo, 2003, p. 188; HABERMAS, Teoria do agir comunicativo, Tomo 02, 2012, p. 66.
} 
ouvinte fazem parte e cuja validade remonta, ainda de modo inquestionado e ingênuo, "ao reconhecimento intersubjetivo, ao assentimento dos concernidos" ${ }^{\prime 159}$.

A moral convencional move-se, destarte, no quadro da facticidade inabalável, da validade objetiva de uma eticidade concreta. Deve-se "à inserção em formas de vida concretas e ingenuamente habitualizadas, que permanecem às costas do sujeito agentes como um pano de fundo inquestionável e pré-reflexivamente presente". Assim, "os juízos morais tomam tanto a concretude quanto a força motivadora da ação à sua ligação intrínseca com as ideias do bem viver e à eticidade institucionalizada" ${ }^{160}$.

Há, enfim, a fusão entre a validade e a facticidade do mundo social, entre a legitimidade e a validade fática, à qual o sujeito heterônomo está integrado e ajustado ${ }^{161}$.

iii) Finalmente, o estágio pós-convencional do juízo moral, marcada pela atitude hipotética, do sujeito em crescimento, frente ao mundo social nativo - no qual ingressara com a passagem para o estágio convencional. Permite-lhe, então, a continuação do agir comunicativo, no âmbito da práxis argumentativa do Discurso ${ }^{162}$.

A força normativa fática, por si, das ordenações esmorece. Dissolve-se a fusão convencional entre legitimidade e validade fática das normas sociais, que marcara a heteronomia moral. Desprendido do contexto do mundo da vida e das certezas que dele afluem, o mundo social é moralizado, pelo participante do discurso. Posto à distância, como pretensão de validade, decompõe-se em convenções carentes de justificação racional $^{163}$.

Diante desse quadro, torna-se necessário outro fundamento para os sistemas normativos que perderam a justificação em sua própria facticidade. $\mathrm{O}$ primeiro passo, destaca Habermas, é dado com a passagem à orientação em função de princípios de

\footnotetext{
${ }^{159}$ HABERMAS, Consciência moral e agir comunicativo, 2003, p. 188 a 190.

${ }^{160}$ HABERMAS, Consciência moral e agir comunicativo, 2003, p. 211 a 213.

${ }^{161}$ HABERMAS, Consciência moral e agir comunicativo, 2003, p. 130, 212 e 213; HABERMAS, Direito $e$ Democracia, Vol. 01, 2012, p. 50.

${ }^{162}$ HABERMAS, Consciência moral e agir comunicativo, 2003, p. 155 e 195; HABERMAS, Teoria do agir comunicativo, Tomo 01, 2012, p. 61.

${ }^{163}$ HABERMAS, Consciência moral e agir comunicativo, 2003, p. 195, 196 e 199.
} 
justiça: "As normas sociais são pensadas agora, de sua parte, como também normalizáveis; elas são subordinadas a princípios, isto é, a normas de nível superior” ${ }^{\text {} 164}$.

Porém, mesmo os princípios demandam de fundamentação. No final das contas, com a moralização do mundo social resta ao sujeito, como instância segura para sua orientação moral, apenas, o processo discursivo em torno da fundamentação das normas. Pois, o ponto de vista moral "não pode ser encontrado num 'primeiro' princípio ou numa fundamentação 'última', ou seja, fora do âmbito da própria argumentação. Apenas o processo discursivo de resgate de pretensões de validez normativa conserva uma força de justificação"165.

Desse modo, na revisita ao modelo de Kohlberg à luz de sua ética procedimental discursiva, Habermas reinterpreta o nível pós-convencional para nele distinguir de um primeiro momento marcado pela orientação em função de princípios universais, no qual “os princípios valem como algo último, que não precisa de fundamentação”, a posterior orientação em função do processo de fundamentação de possíveis princípios, quando “esses princípios são, não apenas manejados de maneira flexível, mas expressamente relativizados com os procedimentos de justificação"166.

Enfim, no processo de desenvolvimento moral cognitivista, concebido por Habermas, a autonomia se realiza, no estágio interação pós-convencional, como um agir emancipado da heteronomia convencional. Referida à atualização do potencial racional comunicativo, na práxis do diálogo, fazendo uso da liberdade comunicativa, induz o agir com responsabilidade e discernimento, de quem pode prestar contas de suas pretensões de validade normativas ${ }^{167}$. O binômio liberdade e responsabilidade, identificado no pensamento de Dewey, reaparece, na filosofia habermasiana, também referido à experiência moral da autonomia.

1.6. É com tal abordagem que a filosofia social crítica de Habermas diagnostica os descaminhos da razão - e da interação linguística - no percurso histórico da modernidade sem cair numa postura antimodernista. À luz da teoria da ação comunicativa e do discurso,

\footnotetext{
${ }^{164}$ HABERMAS, Consciência moral e agir comunicativo, 2003, p. 195, 196 e 199.

${ }^{165}$ HABERMAS, Consciência moral e agir comunicativo, 2003, p. 195, 197, 199 e 211.

${ }^{166}$ HABERMAS, Consciência moral e agir comunicativo, 2003, p. 206.

${ }^{167}$ HABERMAS, Consciência moral e agir comunicativo, 2003, p. 196.
} 
revisita o projeto moderno inacabado de emancipação, pela razão - agora referida à linguagem ${ }^{168}$.

Propõe-se, nessa medida, como filosofia, o papel, mais modesto, de um "guardador de lugar", de guardião da racionalidade, cindida em seus momentos constitutivos e deformada na hipertrofia da perspectiva instrumental ${ }^{169}$.

A proposta filosófica de Habermas não traz consigo pretensões de fundamentação última, ontológica e substancial, e acesso privilegiado à verdade e à moral. A seu ver "Hoje, a filosofia já não pode remeter-se ao mundo, à natureza, à história ou à sociedade como um todo, no sentido de um saber totalizante" ${ }^{170}$.

Destaca, na apresentação da ética procedimental discursiva, que nenhuma autoridade filosófica pode privilegiar de antemão, em sua teoria, determinados conteúdos normativos $^{171}$. Pois, fazendo isso, não pode evitar o grave equívoco de atribuir validade universal a valores ${ }^{172}$ que, "situados nos limites do horizonte do mundo da vida de determinada cultura (...) só podem se tornar plausíveis no contexto de uma forma de vida particular”. Em suma, também o teórico moral deve participar dos discursos reais, "enquanto concernido, eventualmente enquanto perito, mas ele não proceder esses Discursos por sua própria conta"173.

A filosofia habermasiana ocupa-se, então, com o resgate e a manutenção de uma unidade e universalidade da razão, somente possível na comunicação linguística orientada ao entendimento ${ }^{174}$. Volta-se, com isso, ao diálogo emancipador, de forma a "desobstruir o caminho da emancipação", identificando "aquilo que reprime ou distorce o diálogo e a comunicação", e reconstruindo-os, então, "seguindo os vestígios históricos do diálogo reprimido" ${ }^{\prime 175}$.

\footnotetext{
168 HABERMAS, Modernidade - um projeto inacabado, 1992, p. 100; SIEBENEICHLER, Jürgen Habermas, 1994, p. 22.

${ }^{169}$ HABERMAS, O discurso filosófico da modernidade, 2002, p. 438 e 439; HABERMAS, Consciência moral e agir comunicativo, 2003, p. 20, 32 e 34.

${ }^{170}$ HABERMAS, Teoria do agir comunicativo, Tomo 01, 2012, p. 20 e 21.

${ }^{171}$ HABERMAS, Consciência moral e agir comunicativo, 2003, p. 148.

172 BITTAR, Justiça e emancipação, 2011, p. 279.

173 HABERMAS, Consciência moral e agir comunicativo, 2003, p. 117; HABERMAS, Teoria do agir comunicativo, Tomo 01, 2012, p. 90.

${ }^{174}$ SIEBENEICHLER, Jürgen Habermas, 1994, p. 52; BITTAR, Justiça e emancipação, 2011, p. 51.

175 SIEBENEICHLER, Jürgen Habermas, 1994, p. 47 e 50.
} 
Nesse movimento, a filosofia, tal como em Dewey, não pretende, absolutamente, se opor à ciência e técnica moderna, aparecendo, antes, como um "agente de ligação"176. Transmuda-se em "processo de cooperação interdisciplinar"177, uma visão de trânsito dialógico intenso entre as diversas áreas do saber, "como forma de compreensão da complexidade das relações que definem a condição das sociedades contemporâneas"178.

Desse modo, cumpre-lhe desempenhar um duplo papel de mediação hermenêutica: entre as esferas altamente especializadas da razão cindida, encapsuladas cartesianamente em "culturas de especialistas" - a técnica e a ciência; o direito e a moral; a arte; e, ainda, entre tais culturas e as estruturas do mundo da vida ${ }^{179}$.

Desse modo, pode contribuir com a atualização, na interação social, do potencial da razão em toda sua extensão. Isso, num processo de aprendizagem, emancipatório, ínsito à prática comunicativa, por meio do qual os processos linguisticos de entendimento, entre os sujeitos imersos no mundo da vida, podem prevalecer, impondo limites às dinâmicas próprias dos sistemas sociais parciais e da racionalidade neles efetivada ${ }^{180}$.

É sob tal perspectiva filosófica que Habermas concebe a democracia. É, ademais, a partir de seus conceitos e elementos fundamentais que pode se entrever uma teoria pedagógica - correlata à convivência democrática - da ação comunicativa.

\section{O modelo habermasiano de democracia}

Apoiando-o na teoria do agir comunicativo e do discurso, Habermas apresenta seu modelo procedimentalista de democracia - denomina, também, política deliberativa definindo-o como uma experiência social de autodeterminação, de autolegislação, enfim, de autonomia, que se atualiza na formação racional-discursiva da opinião e $\operatorname{vontade}^{181}$.

Trata-se de experiência compreendida de forma ampliada, acompanhando preocupações e aproximando-se muito, nas soluções propostas, da filosofia social de

${ }^{176}$ DEWEY, John. The quest for certainty: a study of relation of knowledge and action. New York: Minton, Balch \& Company, 1929, p. 311.

${ }^{177}$ SIEBENEICHLER, Jürgen Habermas, 1994, p. 52.

${ }_{178}$ BITTAR, A justiça e a liberdade na filosofia do direito de Jürgen Habermas, 2012, p. 252 e 253.

${ }^{179}$ HABERMAS, Modernidade - um projeto inacabado, 1992, p. 120; HABERMAS, Consciência moral e agir comunicativo, 2003 , p. 32 e 33.

${ }^{180}$ HABERMAS, Modernidade - um projeto inacabado, 1992, p. 120; HABERMAS, Teoria do agir comunicativo, Tomo 01, 2012, p. 57; HABERMAS, Teoria do agir comunicativo, Tomo 02, 2012, p. 595.

${ }^{181}$ HABERMAS, Jürgen. A inclusão do outro, 2007, p. 277, 278 e 287; HABERMAS, Direito e democracia, Vol. 01, 2012, p. 157; HABERMAS, Direito e democracia, Vol. 02, 2011, p. 21 a 23. 
Dewey. Concebida a sociedade, ao mesmo tempo, como mundo da vida e sistema, a democracia, não prescinde da esfera governamental - o sistema político - e de suas estruturas. E isso, de forma tal que, institucionalizado juridicamente o princípio do discurso, seja amarrado um procedimento que assegure a participação simétrica e eficaz dos cidadãos nos rumos e na normatização da sociedade - passando, para tanto, também, pelo sufrágio universal, pelos direitos fundamentais, pela regra da maioria, pelas eleições periódicas, etc. Contudo, a experiência democrática não pode ser limitada ao que ocorre na esfera sistêmica. Pois é apreendida na precedência de momento comunicativo anterior que, conduzido pela sociedade civil, tem lugar na esfera pública, enraizada no mundo da vida racionalizado $^{182}$ :

A distinção entre sistema e mundo da vida identifica (...) a democracia com os processos normativos constitutivos do mundo da vida. Dessa maneira, a democracia depende, para a sua reprodução, não apenas daqueles processos que ocorrem no sistema político stricto sensu aglutinação da opinião pública em partidos, atividades parlamentares e eleições -, mas depende também dos processos de formação e renovação de uma cultura política democrática ${ }^{183}$.

Nesse sentido, para Habermas, o processo democrático constitui-se discursivamente, num fluxo de comunicação, que tem início, no âmbito da esfera pública, com a percepção, identificação e debate público de problemas relevantes pela sociedade civil; passa pela luta por reconhecimento de pretensões e pela formação da opinião pública; até, finalmente, desembocar no tratamento e solução institucional, pelo medium do direito, no âmbito do sistema político ${ }^{184}$.

A perspectiva sistêmica, assumida pela filosofia habermasiana, não se confunde, absolutamente, com a concepção autopoiética de Luhmann, de um sistema "funcionalmente especificado que se reproduz a si próprio, operando de modo autorreferencial, isto é, que só elabora informações exteriores na medida do próprio código" ${ }^{185}$. Com efeito, os sistemas sociais parciais - e isso vale para todos eles, destacando-se, aqui, além do político, o jurídico - são interpretados "como sistemas

182 HABERMAS, Direito e democracia, Vol. 01, 2012, p. 145, 146 e 158; HABERMAS, Direito $e$ democracia, Vol. 02, 2011, p. 26, 27, 42 e 92; HABERMAS, Teoria do agir comunicativo, Tomo 01, 2012, p. 588; HABERMAS, Teoria do agir comunicativo, Tomo 02, 2012, p. 592 e 596.

${ }_{183}$ AVRITZER, A moralidade da democracia, 1996, p. 20.

${ }^{184}$ HABERMAS, A inclusão do outro, 2007, p. 289; HABERMAS, Direito e democracia, Vol. 02, 2011, p. $22,23,41$ e 92.

${ }^{185}$ HABERMAS, Direito e democracia, Vol. 01, 2012, p. 224. 
abertos que se mantêm numa relação com um entorno instável e supercomplexo, por meio de processos de troca que ultrapassam seus próprios limites" ${ }^{\text {186 }}$.

Sendo assim, o sistema político e o poder administrativo do Estado que nele se destaca, não devem "reproduzir-se a si mesmo". Devem constituir-se e se regenerar a partir do poder comunicativo, isto é, criado comunicativamente, em esferas públicas que se instituem no mundo da vida, entre sujeitos que agem em conjunto, a partir da interação linguística voltada ao entendimento ${ }^{187}$.

Nota-se, aqui, que o autor não reduz a atuação central da sociedade civil à sociedade econômica capitalista, estruturada conforme as regras do mercado. A saída democrática para o totalitarismo do sistema político - no autoritarismo, à direita (nazifascismo) ou à esquerda (stalinismo), que marcara a história do século $\mathrm{XX}^{188}$ - não induz o totalitarismo do capital.

Seu modelo normativo de democracia assimila aspectos dos modelos liberal e republicano, para, como o primeiro, respeitar as fronteiras entre Estado e sociedade. E, do segundo, absorver a vantagem de colocar no centro o "processo político de formação da opinião e da vontade". Afirma-se, com isso, no sentido radicalmente democrático da "auto-organização da sociedade pelos cidadãos em acordo mútuo por via comunicativa"; isto é, de uma práxis de autodeterminação que não dispensa a estrutura governamental e cujo "paradigma não é o mercado, mas sim a interlocução"189.

Desse modo, a democracia desabrocha sobre uma base social que, contando com a intersubjetividade de processos linguisticos de entendimento - e, por conseguinte, complementa Habermas, baseando-se na cooperação e solidariedade que é própria distingue-se e pode orientar tanto o sistema econômico, mediado pelo dinheiro, como o sistema político, regido pelo poder ${ }^{190}$. Em suma, pode reverter a contaminação e colonização sistêmica do mundo da vida.

\footnotetext{
${ }^{186}$ HABERMAS, Teoria do agir comunicativo, Tomo 02, p. 274.

${ }^{187}$ HABERMAS, A inclusão do outro, 2007, p. 289; HABERMAS, Teoria do agir comunicativo, Tomo 02, 2012, p. 278 e 334; HABERMAS, Direito e democracia, Vol. 01, 2012, p. 185, 186, 187 e 190.

${ }^{188}$ HOBSBAWN, Eric. Era dos extremos. O breve século XX: 1914-1989. $2^{\mathrm{a}}$ ed. Trad. Marcos Santarrita. Rev. Téc. Maria Célia Paoli. São Paulo: Cia das Letras, 2000, 17.

${ }^{189}$ HABERMAS, Direito e democracia, Vol. 02, 2011, p. 18 a 21; HABERMAS, A inclusão do outro, 2007, p. 278, 283, 284 e 288.

${ }^{190}$ HABERMAS, Direito e democracia, Vol. 02, 2011, p. 22; HABERMAS, A inclusão do outro, 2007, p. 278 e 289.
} 
E, assim, no cenário pós-metafísico, em que o direito positivo não pode mais "reclamar para si nenhuma validade moral ou jusnatural pré-ordenada à formação da vontade dos cidadãos”, Habermas refere a legitimidade do sistema jurídico à abertura ao procedimento democrático da formação discursiva da opinião e da vontade. Uma legitimidade que, unindo soberania popular e direitos humanos, efetiva-se a partir da legalidade, amparada na racionalidade do direito, e, nessa linha, na resgatabilidade discursiva de sua pretensão de validade normativa ${ }^{191}$.

É com essa configuração que, na filosofia social habermasiana, a democracia é entrelaçada com os conceitos de política, direito, razão e moral $^{192}$ e aparece- como também havia vislumbrado Dewey - como o locus da realização do projeto moderno emancipatório.

2.1. O caminho comunicativo a ser percorrido na sociedade democrática, abrangendo distintos atores, espaços e estruturas, deve seguir uma direção centrípeta, que vai de "fora", da "periferia social" para o "centro" político. Começa, assim, na estrutura comunicacional da esfera pública, referida ao mundo da vida, através da sociedade civil $^{193}$.

Habermas concebe a sociedade civil na perspectiva de movimentos, associações e organizações "não estatais e não econômicas, as quais ancoram as estruturas de comunicação da esfera pública nos componentes sociais do mundo da vida". Eles "captam os ecos dos problemas sociais que ressoam nas esferas públicas, condensam-nos e os transmitem, a seguir, para a esfera pública política"194.

Constitui uma base social que se distingue das estruturas sistêmicas da administração estatal e da economia de mercado e, dessa forma, pode, em práticas comunicativas orientadas ao entendimento, não se contaminar pelos meios poder e dinheiro $^{195}$.

191 HABERMAS, Direito e democracia, Vol. 01, 2012, p. 50, 133 e 188; HABERMAS, Direito $e$ democracia, Vol. 02, 2011, p. 214.

${ }^{192}$ HABERMAS, Direito e democracia, Vol. 02, 2011, p. 234.

${ }^{193}$ HABERMAS, Direito e democracia, Vol. 02, 2011, p. 89, 92 e 115.

${ }^{194}$ HABERMAS, Direito e democracia, Vol. 02, 2011, p. 100.

${ }^{195}$ HABERMAS, A inclusão do outro, 2007, p. 278. 
Também em Habermas, se, por um lado, a sociedade civil não se restringe à perspectiva liberal individualista de indivíduos atomizados que, sem qualquer orientação axiológica comum, coordenam a ação de forma estratégica e concorrencial em vista do êxito egoísta; por outro, não corresponde a uma visão totalizante de um ator coletivo orgânico, em prejuízo da individualidade. Afinal, a identidade ética do grupo faz-se na dialética da constituição social da personalidade. Remete, sem dúvida, a situações nas quais os atores sociais podem "dizer enfaticamente "nós"”; porém, "ela não constitui uma identidade-eu em tamanho grande, e sim, o seu complemento"196.

A sociedade civil se forma, então, a partir da interação social e de diversos modos de associação que funcionam como "substrato organizatório do público de pessoas privadas que buscam interpretações públicas para suas experiências e interesses sociais, exercendo influência sobre a formação institucionalizada da opinião e da vontade"197.

Assim constituída, a sociedade civil atua no âmbito da esfera pública, "fenômeno social elementar, do mesmo modo que a ação, o ator, o grupo ou a coletividade". Na definição habermasiana, corresponde a uma estrutura, uma rede de comunicação intermediária que, reproduzindo-se por meio do agir comunicativo cotidiano, pode fazer a "mediação entre ao sistema político, de um lado, e os setores privados do mundo da vida e os sistemas de ação especializados em termos de funções, de outro lado"198.

A esfera pública retira seus "impulsos" da assimilação pelos sujeitos privados de problemas sociais que repercutem em suas histórias particulares ${ }^{199}$. E se atualiza - em total harmonia com a proposta deweyana de demarcação experimental da linha divisória entre o público e o privado - a partir do reconhecimento, pelo grupo social, da dimensão intersubjetiva de questões que sobre ele se projetam. Projeção de tais proporções que demanda a intervenção do público ${ }^{200}$. Na dualidade dos sujeitos membros da sociedade e cidadãos do Estado, as experiências dos problemas e conflitos são, no início:

\footnotetext{
${ }^{196}$ HABERMAS, Direito e democracia, Vol. 01, 2012, p. 201; HABERMAS, Direito e democracia, Vol. 02, 2011 , p. 20 e 21.

${ }^{197}$ HABERMAS, Direito e democracia, Vol. 02, 2011, p. 100.

198 HABERMAS, Direito e democracia, Vol. 02, 2011, p. 92, 93 e 108; HABERMAS, Teoria do agir comunicativo, Tomo 01, 2012, p. 588.

${ }^{199}$ HABERMAS, Direito e democracia, Vol. 02, 2011, p. 99.

${ }^{200}$ DEWEY, John. The public and its problems. Swallow Press/Ohio University/Athens, 1991, p. 15, 39 e 64.
} 
(...) elaboradas de modo "privado", isto é, interpretadas no horizonte de uma biografia particular, a qual se entrelaça com outras biografias, em contextos de mundos da vida comuns. Os canais de comunicação da esfera pública engatam-se nas esferas da vida privada - as densas redes de interação da família e do círculo de amigos e os contatos mais íntimos com vizinhos, colegas de trabalho, conhecidos, etc. - de tal modo que as estruturas espaciais de interações simples podem ser ampliadas e abstraídas, mas não destruídas. De modo que a orientação pelo entendimento continua valendo também para a comunicação entre estranhos, que se desenvolve em esferas públicas ${ }^{201}$.

Constitui-se, então, na atuação dos movimentos, associações e organizações sociais, como uma rede para a "comunicação de conteúdos, tomadas de posição e opiniões". Numa pluralidade de vozes, concepções de vida e orientações axiológicas e teleológicas, identificam e reagem às situações sociais problemáticas, tematizando-as, debatendo-as e filtrando-as em opiniões públicas. Tudo isso, num "longo caminho" de luta por reconhecimento e convencimento, no curso do qual o tema pode ser apreendido como relevante, público, ao ponto de ser assimilado pelas esferas governamentais do sistema político - às quais se reserva, no final das contas, a tomada da decisão institucional:

Somente após uma "luta por reconhecimento", desencadeada publicamente, os interesses questionados podem ser tomados pelas instâncias políticas responsáveis, introduzidos nas agendas parlamentares, discutidos e, eventualmente, elaborados na forma de propostas e decisões impositivas $^{202}$.

No cenário assim traçado, a qualidade da opinião pública, a interferir na decisão política, pela linguagem do direito, passa a ser medida, não per se por sua generalidade, mas, fundamentalmente, em termos formais: pelo nível racional-discurso dos procedimentos de sua formação, passando, portanto, pela percepção dos problemas, pela elaboração das propostas e pretensões, pela comunicação social e acesso à informação, pela práxis da argumentação ${ }^{203}$.

A influência fática e a legítima não se confundem. A qualidade procedimental discursiva da opinião pública, mantendo-a distante de interesses econômicos e políticos privilegiados, torna-se a medida da legitimidade da influência e da pressão exercida sobre o sistema político $^{204}$.

\footnotetext{
${ }^{201}$ HABERMAS, Direito e democracia, Vol. 02, 2011, p. 99.

${ }^{202}$ HABERMAS, Direito e democracia, Vol. 02, 2011, p. 23, 41, 92, 93 e 94.

${ }^{203}$ HABERMAS, Direito e democracia, Vol. 02, 2011, p. 95.

${ }^{204}$ HABERMAS, Direito e democracia, Vol. 01, 2012, p. 190; HABERMAS, Direito e democracia, Vol. 02, 2011, p. 95.
} 
2.2. O fluxo comunicacional assim percorrido e o poder comunicativo nele gerado legitimamente, apoiado no mundo da vida, podem "através das comportas do processo democrático", ecoar e direcionar o sistema político. E, desse modo, problemas sociais são solucionados e pretensões atendidas institucionalmente, na forma jurídica de resoluções legislativas, decisões judiciais e atos administrativos ${ }^{205}$.

O sistema político, incluindo a estrutura dos três Poderes (passando pelos órgãos executivos, o "complexo parlamentar e os "tribunais"), aparece, para Habermas, apenas, como um segmento - diz, inclusive, estreito - da vida pública. Trata-se de "um sistema de ação ao lado de outros, não o centro, nem o ápice, muito menos o modelo estrutural da sociedade" 206 .

Não obstante, assume o fundamental papel garantidor em relação a "perdas em termos de integração" em toda a sociedade. A política "tapa buracos funcionais que se abrem devido à sobrecarga advinda de outros mecanismos de integração social". Comunicando-se com os demais domínios da interação, continua, no nível reflexivo -, e pelo filtro discursivo - a "integração social que outros sistemas de ação não conseguem mais desempenhar suficientemente" ${ }^{207}$.

O sistema político é concebido, em suma, como sistema parcial de ação que, através do medium do direito, é "responsável por problemas que atingem a sociedade como um todo", especializando-se "na produção de decisões que envolvem a coletividade". A política - aberta e vinculada discursivamente à esfera pública e à sociedade civil - e o direito, nessa medida legitimamente gerado, fundem-se num "processo destinado a solucionar problemas":

Onde outros reguladores fracassam - como é o caso dos padrões de coordenação que se apoiam em valores, normas e rotinas de entendimento convencionais - a política e o direito conseguem elevar, de certa forma, os processos solucionadores de problemas acima do limiar da consciência $^{208}$.

2.3. É dessa forma que o processo de formação discursivo da opinião e da vontade definidor da democracia -, passando pelos espaços e atores da sociedade civil, da esfera

${ }^{205}$ HABERMAS, A inclusão do outro, 2007, p. 289; HABERMAS, Direito e democracia, Vol. 02, 2011, p. 23, 56, 92, 105 e 121 .

${ }^{206}$ HABERMAS, Direito e democracia, Vol. 02, 2011, p. 25, 91 e 220.

${ }^{207}$ HABERMAS, Direito e democracia, Vol. 02, 2011, p. 25, 45 e 46.

${ }^{208}$ HABERMAS, Direito e democracia, Vol. 02, 2011, p. 45, 46 e 120. 
pública e do sistema jurídico, supõe e redunda, num movimento dialético de autolegislação, no direito legítimo. A legitimidade, em Habermas, dá-se partir da legalidade democrática.

$\mathrm{O}$ ordenamento jurídico - e, em seu interior, os direitos fundamentais e os procedimentos políticos-democráticos - garante condições comunicativas mínimas, na linha da situação dialogal ideal, e, destarte, possibilitam, sem impor, o arranjo discursivo em que se apoia a formação legítima do direito. Nesse medium, o princípio da soberania popular, interpretado de modo intersubjetivista, "retira-se para o anonimato dos processos democráticos e para a implementação jurídica de seus pressupostos comunicativos pretensiosos para fazer-se valer como poder produzido comunicativamente". Ao atualizálo, os atores sociais movem-se no sistema jurídico democrático ao mesmo tempo em que o constroem e o renovam ${ }^{209}$.

A ideia de autolegislação, afirma Habermas, "exige que os que estão submetidos ao direito, na qualidade de destinatários, possam entender-se também enquanto autores do direito". E isso, a partir da efetivação do princípio do discurso, de modo que "somente podem pretender validade legítima as leis jurídicas capazes de encontrar o assentimento de todos os parceiros do direito, num processo jurídico de normatização discursiva". Resume: o princípio da democracia, legitimador do processo de normatização e oposto a qualquer forma de violência, resulta do entrelaçamento entre o princípio do discurso e a forma jurídica $^{210}$.

Tal movimento espiral - porém, de forma nenhuma, fechado, reflexivo ou autopoiético, como a proposta sistêmica luhmanniana ${ }^{211}$ - aparece na interpretação habermasiana dos direitos fundamentais, referida ao discurso, composta de cinco categorias, conforme descrito no Capítulo I.

Habermas apresenta, em primeiro lugar, a categoria dos direitos a iguais liberdades subjetivas de ação - configurados historicamente nos direitos liberais à vida, à integridade, à liberdade, à propriedade, dentre outros - e, a eles correlatos, os direitos de associação,

${ }^{209}$ HABERMAS, Direito e democracia, Vol. 01, 2012, p. 138; HABERMAS, Direito e democracia, Vol. 02, 2011, p. 24 e 45.

${ }^{210}$ HABERMAS, Direito e democracia, Vol. 01, 2012, p. 138, 145, 157 e 158.

${ }^{211}$ HABERMAS, Direito e democracia, Vol. 02, 2011, p. 222 e 230; LUHMANN, Niklas. Sociologia do direito II. Trad. Gustavo Bayer. Rio de Janeiro: Tempo brasileiro, 1985, p. 16 e 17. 
em que se concretiza o status de um membro da sociedade (os direitos de nacionalidade), e de garantias do caminho do direito, atualizados em direitos processuais ${ }^{212}$.

Assim reconhecidos reciprocamente pelos sujeitos, enquanto destinatários do direito, tais categorias fundam, em conjunto, um medium jurídico, erigindo um status pessoal garantidor da integridade e autonomia privada. A partir de então, os sujeitos podem assumir, também, o papel de autores do direito, regulando autônoma e legitimamente sua convivência e, por conseguinte, entendendo-se quanto aos "direitos aos quais desejam submeter-se como destinatários"213.

Isso ocorre pela via da quarta categoria habermasiana, dos direitos fundamentais de participação, em igualdade de condições, dos processos de formação da opinião e da vontade, fazendo uso público de sua liberdade comunicativa. Trata-se dos direitos políticos, os quais devem assegurar:

(...) a participação em todos os processos de deliberação e de decisão relevantes para a legislação, de modo que a liberdade comunicativa de cada um possa vir simetricamente à tona, ou seja, a liberdade de tomar posição em relação a pretensões de validade criticáveis. À juridificação simétrica do uso político de liberdades comunicativas corresponde o estabelecimento de uma formação política da opinião e da vontade, na qual o princípio do discurso encontra aplicação ${ }^{214}$.

Enquanto os direitos a iguais liberdades subjetivas de ação e os correlatos de direitos de associação e de garantias do caminho do direito situam-se precipuamente no âmbito da autonomia privada dos sujeitos de direito, os direitos de participação, fundamentando o status de cidadão, têm a ver com a autonomia política. Todos eles implicam, por último, a quinta categoria dos "Direitos fundamentais a condições de vida garantidas social, técnica e ecologicamente". Concretiza-se, por exemplo, em direitos à educação, à saúde, à cultura, ao desenvolvimento científico e tecnológico, ao meio ambiente ecologicamente equilibrado, dentre tantos outros, sempre na medida em que necessários para o aproveitamento, em condições de igualdade, dos direitos referentes às quatro categorias anteriores $^{215}$.

${ }^{212}$ HABERMAS, Direito e democracia, Vol. 01, 2012, p. 159 e 162.

${ }^{213}$ HABERMAS, Direito e democracia, Vol. 01, 2012, p. 121, 159, 162, 163 e 165.

${ }^{214}$ HABERMAS, Direito e democracia, Vol. 01, 2012, p. 159 e 164.

${ }^{215}$ HABERMAS, Direito e democracia, Vol. 01, 2012, p. 160; PINZANI, Habermas, 2009, p. 150. 
É referida, assim, a essas cinco categorias fundamentais, que a práxis de autolegislação adquire sentido no âmbito do próprio sistema jurídico, em que são garantidas, pelo direito, condições para sua própria construção discursiva ${ }^{216}$.

Opondo-se a qualquer "duplicação" metafísica do direito, legada do platonismo, Habermas desloca a legitimidade do sistema jurídico para o procedimento discursivo da opinião e da vontade, juridicamente institucionalizado, no fluxo comunicacional e racional que vai da sociedade civil ao sistema político. Pode conceber a legitimidade, referida ao exercício intersubjetivo e democrático da soberania popular, na legalidade. Sem se perder, por conseguinte, em perspectivas positivistas e sistêmicas, nas quais o direito, legitimandose a si mesmo, desengata-se de questões morais ${ }^{217}$.

$\mathrm{O}$ direito, instrumentalmente referido à política, mantém-se, também, entrelaçado com a moral. Para o autor, a intuição platônica, em que se opõem experiências concretas a modelos ideais, "não é de todo falsa". No debate da legitimidade, "o direito adquire uma relação com a moral"; uma relação, contudo, que "não deve levar-nos a subordinar o direito à moral, no sentido de uma hierarquia de normas"218. Complementa:

(...) as ordens modernas do direito só podem ser legitimadas a partir de fontes que não o colocam em contradição com as ideias de justiça e os ideais de vida pós-tradicionais que se tornaram decisivos para a cultura e a conduta de vida. Argumentos em prol da legitimidade do direito devem ser compatíveis com os princípios morais da justiça e da solidariedade universal (...) bem como com os princípios éticos de uma conduta de vida autorresponsável, projetada conscientemente, tanto de indivíduos, como de coletividades ${ }^{219}$.

Se o discurso jurídico é permeável ao discurso moral - no qual, como visto, buscase a regulação da convivência no interesse simétrico de todos, para além da perspectiva etnocentrista do participante - ele, absolutamente, não se reduz a isso. A formação da vontade política, pela linguagem do direito, envolve outras modalidades de argumentações. Abrange discursos éticos, também já referidos acima, em que, trazido o horizonte ético de orientações axiológicas para dentro do procedimento argumentativo, são fundamentados programas e normas de ação, "na medida em que eles são adequados e, num sentido amplo,

\footnotetext{
${ }^{216}$ HABERMAS, Direito e democracia, Vol. 01, 2012, p.163 e 164.

${ }^{217}$ HABERMAS, Direito e democracia, Vol. 01, 2012, p. 118, 140 e 168.

${ }^{218}$ HABERMAS, Direito e democracia, Vol. 01, 2012, p. 140 e 141; HABERMAS, Direito e democracia, Vol. 02, 2011, p. 218 e 234.

${ }^{219}$ HABERMAS, Direito e democracia, Vol. 01, 2012, p. 132 e 133.
} 
bons para nós". E isso pelo caminho do autoentendimento que se apropria das tradições e da forma de vida, sem, todavia, para fora delas se catapultar. Inclui, ainda, discursos pragmáticos, os quais se prestam à ponderação e escolha de meios para a realização de fins dados ou, ainda, à avaliação racional de fins coletivos, sem problematizar, em nenhuma medida, as preferência, orientações e interesses axiológicos assumidos pelo grupo ${ }^{220}$.

Habermas fala, finalmente, em negociações equitativas entre partidos e grupos que agem estrategicamente, orientados ao êxito. Têm lugar quando não é possível neutralizar as relações de poder, como pressuposto no discurso racional, de modo que as vias argumentativas supramencionadas não estão suficientemente abertas. Nas interações negociais, introduz-se o "poder de negociação que vem acompanhado de ameaças e promessas, que pode extrair da linguagem utilizada em comum as energias ilocucionárias e limitar o uso da linguagem à obtenção estratégica de efeitos perlocucionários"221

Contudo, também aqui, destaca Habermas, o princípio do discurso atua, mesmo que por um caminho moralizador indireto. Afinal, os compromissos obtidos exprimem-se em termos de um acordo que equilibra interesses conflitantes, motivado racionalmente, ainda que por diferentes razões:

Se a negociação de compromissos decorrer conforme procedimentos que garantem a todos os interesses iguais chances de participação nas negociações e na influenciação recíproca, bem como na concretização de todos os interesses envolvidos, pode-se alimentar a suposição plausível de que os pactos a que se chegou são conformes à equidade ${ }^{222}$.

As negociações, na medida em que pressupõem o discurso, não o destroem. Ele vale, ainda que indiretamente e com ressalvas, também aqui. Sem isso, estaríamos diante do uso puro e imediato, sem disfarce, da "linguagem" da violência ${ }^{223}$.

Por tudo isso, o entrelaçamento entre o sistema jurídico e a moral, para Habermas, efetiva-se no sentido de uma moralidade que "não paira mais sobre o direito", enquanto conteúdos normativos determinados. Ela migra para o direito e nele se estabelece de modo procedimental: a moralidade da práxis do discurso, inerente, é claro, às argumentações

${ }^{220}$ HABERMAS, Direito e democracia, Vol. 01, 2012, p. 143, 199, 200,202, 203 e 205; HABERMAS, Direito e democracia, Vol. 02, 2011, p. 216.

${ }^{221}$ HABERMAS, Direito e democracia, Vol. 01, 2012, p. 208.

${ }^{222}$ HABERMAS, Direito e democracia, Vol. 01, 2012, p. 207 e 208.

${ }^{223}$ HABERMAS, Direito e democracia, Vol. 01, 2012, p. 207 e 209. 
morais, mas presente também nas argumentações éticas e pragmáticas. Não se perde, como visto, em absoluto, nem mesmo nas negociações estrategicamente orientadas ${ }^{224}$.

É nesse quadro, enfim, que o debate ganha robustez, pensado em termos de legitimidade, referida à racionalidade comunicativa do processo de autolegislação democrática e, dessa forma, à resgatabilidade discursiva, em toda a sua extensão, da pretensão de validade de um direito orientado à regulação cooperativa da convivência entre atores sociais que renunciaram ao uso da violência ${ }^{225}$.

2.4. Não são poucos, porém, os obstáculos que, no plano fático, podem ser opostos à efetivação desse modelo procedimental-discursivo de democracia. Ligam-se, fundamentalmente, aos exigentes pressupostos da práxis argumentativa do discurso, com a presença de atores comunicativamente competentes numa situação ideal de fala ${ }^{226}$.

Destacam-se, em primeiro lugar, as dificuldades para se atualizar, na esfera pública, uma ambiência discursiva livre de coações, ameaças, engodo e violência, caracterizada por efetivas e iguais oportunidades de participação e pela compreensão esclarecida, pelos envolvidos, das questões debatidas. Trata-se de padrões ideias que, lembra Dahl, constituem possibilidades humanas que, talvez, nunca possam ser plenamente satisfeitas $^{227}$.

O processo histórico de colonização do mundo da vida pelos imperativos dos sistemas parciais - a política e o mercado capitalista - dá uma medida do problema. O dinheiro e o poder substituem a linguagem como mecanismo de coordenação da ação, solapando a interação social linguisticamente orientada ao entendimento, em favor do agir estratégico, orientado ao êxito individual. A esfera pública esvazia-se, reprimida por coações sistêmicas e contaminada por interesses políticos e econômicos ${ }^{228}$.

\footnotetext{
${ }^{224}$ HABERMAS, Direito e democracia, Vol. 02, 2011, p. 218.

${ }^{225}$ HABERMAS, Direito e democracia, Vol. 02, 2011, p. 27, 33 e 47.

${ }^{226}$ HABERMAS, Direito e democracia, Vol. 02, 2011, p. 09.

227 DAHL, Robert. A. A democracia e seus críticos. Trad. Patrícia de Freitas Ribeiro. São Paulo: Editora WMF Martins Fontes, 2012, p. 171, 172, 176 e 179; HABERMAS, Teoria do agir comunicativo, Tomo 01, 2012, p. 61; HABERMAS, Direito e democracia, Vol. 02, 2011, p. 42, 43 e 215.

${ }^{228}$ HABERMAS, Direito e democracia, Vol. 02, 2011, p. 09 e 107; HABERMAS, Teoria do agir comunicativo, Tomo 01, 2012, p. 589; HABERMAS, Teoria do agir comunicativo, Tomo 02, 2012, p. 587 e 588 .
} 
Habermas destaca, nesse ponto, os prejuízos à comunicação numa esfera pública sempre mais dominada "pelos meios de comunicação de massa e pelas grandes agências, observada pelas instituições encarregadas da pesquisa de opinião e do mercado, e sobrecarregada com o trabalho de publicidade e de propaganda dos partidos e organizações políticas". Um espaço onde, ademais, na concorrência entre programas de várias "emissoras" e mídias e a fim de ganhar a atenção do público:

(...) a apresentação de notícias e comentários segue conselhos e receitas dos especialistas em propaganda. A personalização das questões objetivas, a mistura entre informação e entretenimento, a elaboração episódica e a fragmentação de contextos formam uma síndrome que promove a despolitização da comunicação pública ${ }^{229}$.

Num ciclo vicioso, os processos públicos de comunicação são submetidos a distorções e manipulações oriundas do "uso não declarado do dinheiro e do poder organizacional”, de influências "político-publicitárias", que somente discursivamente, na esfera pública assim viciada e esvaziada, podem ser desmascaradas e neutralizadas. Tudo a enfraquecê-los como mecanismos discursivos de reconhecimento, interpretação, debate e tratamento de problemas sociais e, desse modo, como fonte de poder comunicativo que, apoiada no mundo da vida, fundamenta e legítima a atuação do sistema político ${ }^{230}$.

Do lado dos atores que compõem a sociedade civil, a participação competente nos discursos racionais exige, como lembra Habermas, um nível mínimo de escolaridade, um satisfatório grau de informação e esclarecimento e, ainda, uma capacidade cognitiva e moral do sujeito para o enfrentamento, crítica e fundamentação de temas e questões polêmicas $^{231}$.

Requer, por conseguinte, personalidades, num mundo da vida racionalizado, capazes de, comunicativamente, "farejar problemas latentes de integração social (cuja elaboração é essencialmente política), identificá-los, tematizá-los e introduzi-los no sistema político, passando pelas comportas do complexo parlamentar (ou dos tribunais) ${ }^{, 232}$.

\footnotetext{
${ }^{229}$ HABERMAS, Direito e democracia, Vol. 02, 2011, p. 100, 111 e 114.

${ }^{230}$ HABERMAS, Direito e democracia, Vol. 02, 2011, p. 24, 97, 109, 113 e 121.

${ }^{231}$ HABERMAS, Direito e democracia, Vol. 02, 2011, p. 220.

${ }^{232}$ HABERMAS, Direito e democracia, Vol. 02, 2011, p. 91.
} 
Habermas não está sugerindo, absolutamente, uma sociedade civil composta de especialistas. Também aqui seu pensamento coaduna-se com a filosofia deweyana. Afirma, aliás, contra a tecnocracia, que "Quando o discurso dos especialistas está desvinculado da formação democrática da opinião e da vontade, ele se afirma contra as pessoas privadas". E complementa: "O fato de o público ser composto de leigos e de a comunicação pública se dar numa linguagem compreensível não significa necessariamente um obscurecimento das questões essenciais ou das razões que levam a uma decisão"233.

Pois, valendo-se da linguagem comum que, para além da "diferenciação dos códigos especializados", "circula em toda a sociedade", os atores sociais podem se opor às interpretações e aos programas do sistema político, mobilizando um saber alternativo e elaborando traduções próprias, também apoiadas em avaliações técnicas especializadas $^{234}$.

A atuação comunicativamente competente da sociedade civil passa, ainda, pela propensão do cidadão ao uso público da liberdade comunicativa, participando dos discursos sobre questões sociais relevantes. A práxis de autolegislação "ensina serem os destinatários simultaneamente os autores de seus direitos". Não abre mão da participação dos sujeitos de direito como seus autores, confrontando-os em suas expectativas e pretensões e extraindo a "força legitimadora do processo de um entendimento dos cidadãos sobre as regras de sua convivência” ${ }^{, 235}$.

Esse exercício ativo e discursivo da cidadania constitui, contudo, "fardo" do qual, paradoxalmente - na linha do que fora antecipado sobre a disposição comunicativa -, o sujeito é aliviado ao fazer uso de sua liberdade subjetiva, de sua autonomia privada, conforme garantido pelo próprio ordenamento jurídico ${ }^{236}$.

Em termos kantianos, a norma jurídica, diferentemente da moral, estende-se, ao aspecto exterior do agir, "não abrangendo, pois, motivos e sentimentos que não podem ser forçados" 237 . Reclama, no final das contas, "menos consciência e mais obediência"238.

\footnotetext{
${ }^{233}$ HABERMAS, Direito e democracia, Vol. 02, 2011, p. 83 e 107.

${ }^{234}$ HABERMAS, Direito e democracia, Vol. 02, 2011, p. 84 e 107.

${ }^{235}$ HABERMAS, Direito e democracia, Vol. 01, 2012, p. 115 e 139.

${ }^{236}$ HABERMAS, Direito e democracia, Vol. 02, 2011, p. 114, 150, 151 e 164.

${ }^{237}$ HABERMAS, Direito e democracia, Vol. 02, 2011, p. 217.
} 
Com isso, libera o sujeito dos "motivos para um comportamento conforme a regra", tolerando, portanto, o enfoque estratégico ${ }^{239}$.

Nesse sentido, a liberdade subjetiva, juridicamente garantida, pode aparecer com um significado negativo, em oposição à liberdade comunicativa. Fundamenta uma privacidade que "libera do peso da liberdade comunicativa atribuída e imputada reciprocamente". Para o ator "que toma as suas decisões em força da liberdade subjetiva, pouco importa se os argumentos que são decisivos para ele, também poderiam ser aceitos por outros" 240 .

A democracia e o direito democrático, enfim, não obrigam (nem podem) o processo comunicativo - do qual se alimentam - de ocupação da esfera pública pelos atores da sociedade civil. Os direitos políticos "têm de ser formulados numa linguagem que permite aos sujeitos autônomos do direito escolher se e como vão fazer uso deles". Compete:

(...) aos destinatários decidir se eles, enquanto autores, vão empregar sua vontade livre, se vão passar pela mudança de perspectivas que os faça sair do círculo dos próprios interesses e passar para o entendimento sobre normas: capazes de receber o assentimento geral, se vão ou não fazer um uso público de sua liberdade comunicativa ${ }^{241}$.

Por fim, quanto ao sistema político, Habermas ressalta sua posição embaraçosa de um sistema parcial que continua uma integração social que outros subsistemas não puderam desempenhar suficientemente. De um lado, sofre a pressão de problemas oriundos da complexidade social e enfrenta restrições à capacidade de regulação ante a força de grandes organizações e de "outros sistemas de funções que obedecem à sua própria lógica, fechando-se, pois, a intervenções diretas". De outro, há de se manter aberto à esfera pública, "ficando na dependência das fontes do poder comunicativo que se apoia no mundo da vida”. Seu espaço de iniciativa e atuação é limitado:

(...) através da imprevisibilidade, tanto dos eleitores esclarecidos, como dos que são mobilizáveis populisticamente, cujos laços com os partidos são cada vez mais frouxos. Com o azedamento da política, os partidos

${ }^{238}$ BITTAR, Eduardo C. B. A discussão do conceito de direito. Uma reavaliação a partir do pensamento habermasiano. Boletim da Faculdade de Direito. Vol. LXXXI (separata). Universidade de Coimbra, Coimbra, 2005, p. 810.

${ }^{239}$ HABERMAS, Direito e democracia, Vol. 01, 2012, p. 115.

${ }^{240}$ HABERMAS, Direito e democracia, Vol. 02, 2011, p. 52, 155 e 156.

${ }^{241}$ HABERMAS, Direito e democracia, Vol. 01, 2012, p. 167. 
estabelecidos têm que temer pela perda de legitimação provocada pelas vozes de protesto e pelos que não são eleitores ${ }^{242}$.

Desse modo, o sistema político consegue se mover, apenas, num espaço extremamente restrito: "parece que age mais no nível reativo de uma política que tenta contornar crises do que de uma política que planeja”. E atua, assim, tentando combinar efetividade e legitimidade ${ }^{243}$.

Arrisca fracassar em termos de efetividade de sua regulação e de suas realizações, nas situações de irrelevância, orientação errônea e autodestruição, as quais podem acumular-se na forma aguda de um "trilema regulatório":

O sistema político fracassa em sua competência reguladora quando os programas jurídicos implementados ficam sem efeito, quando as realizações de orientação e ordenação desencadeiam efeitos desintegradores nos sistemas de ação carentes de regulação ou quando os meios utilizados sobrecarregam o próprio medium do direito e, com isso, a constituição normativa do próprio sistema ${ }^{244}$.

Arrisca fracassar, também, em termos de legitimidade, quando o sistema político rompe com a formação discursiva da opinião da vontade, proveniente da sociedade civil. Pois, dessa maneira, as decisões institucionais "não importa quanto sejam efetivas, se distanciam do direito legítimo". Isso ocorre quando:

(...) o sistema administrativo se torna independente em relação ao poder produzido comunicativamente, quando o poder social de sistemas de funções de grandes organizações, inclusive os meios de comunicação de massa, se transforma em poder ilegítimo ou quando as fontes do mundo da vida, que alimentam comunicações públicas espontâneas, não são mais suficientes para garantir a articulação livre de interesses sociais ${ }^{245}$.

A prevalência do poder ilegítimo combinada com a fraqueza da sociedade civil e da esfera pública podem configurar, somadas, o que Habermas denomina dilema legitimatório. E este, eventualmente, combinado com o trilema regulatório, pode resultar num desastroso ciclo vicioso, a partir do qual "o sistema político é absorvido por déficits de legitimidade e de regulação que se reforçam mutuamente" 246 .

${ }^{242}$ HABERMAS, Direito e democracia, Vol. 01, 2012, p. 168; HABERMAS, Direito e democracia, Vol. 02, 2011, p. 48, 61, 120 e 121;

${ }^{243}$ HABERMAS, Direito e democracia, Vol. 02, 2011, p. 61 e 121.

${ }^{244}$ HABERMAS, Direito e democracia, Vol. 02, 2011, p. 121.

${ }^{245}$ HABERMAS, Direito e democracia, Vol. 02, 2011, p. 89, 121.

${ }^{246}$ HABERMAS. Direito e democracia, Vol. 02, 2011, p. 121 e 122. 
2.5. Sendo assim, Habermas não negligencia em relação às dificuldades inerentes à implementação radical da democracia, apoiada no conceito de discurso. Identifica, nos agrupamentos da sociedade civil, fragilidades quanto à capacidade de organização e ação, reconhecendo, ainda, que, embora sensíveis aos problemas sociais, "os sinais que emitem e os impulsos que fornecem são, em geral, muito fracos para despertar a curto prazo processos de aprendizagem no sistema político ou para reorientar processos de decisão"247.

Não perde de vista, finalmente, que, reduzido o nível discursivo da comunicação, no espaço público, os temas em geral tendem a ser dirigidos numa direção centrífuga, do "centro político" para fora, pervertendo a direção espontânea que parte da "periferia social”. Possibilita-se, com isso, a perpetuação de um modo rotineiro e ilegítimo de atuação governamental que, "sob a pressão do tempo, têm pouca sensibilidade para problemas latentes, que não são captados pelas rotinas normais ou (são) captados de modo insuficiente, e quase nenhuma iniciativa para a elaboração dramática bem-sucedida de novos problemas",248.

Ainda assim, para o autor, os conceitos de sociedade civil e esfera pública "não representam apenas postulados normativos, pois têm referências empíricas". O ceticismo quanto às possibilidades de que determinem o fluxo da comunicação, direcionando a atuação do sistema político vale, muito mais, a seu ver, para o que denomina esfera pública em repouso. Contudo, "a partir do momento em que acontece uma mobilização, as estruturas sobre as quais se apoia a autoridade de um público que toma posição começam a vibrar. E as relações de forças entre a sociedade civil e o sistema político podem sofrer alterações" 249 .

Enfim, "os atores da sociedade civil, até agora negligenciados, podem assumir um papel surpreendentemente ativo e pleno de consequências, quando tomam consciência da situação de crise". Podem "em certas circunstâncias, ter opiniões públicas próprias, capazes de influenciar o complexo parlamentar (e os tribunais), obrigando o sistema político a modificar o rumo do poder oficial". Apesar de suas limitações, têm a chance de “inverter a direção do fluxo convencional da comunicação na esfera pública e no sistema

\footnotetext{
${ }^{247}$ HABERMAS. Direito e democracia, Vol. 02, 2011, p. 107 e 116.

${ }^{248}$ HABERMAS. Direito e democracia, Vol. 02, 2011, p. 90 e 115.

${ }^{249}$ HABERMAS, Direito e democracia, Vol. 02, 2011, p. 23, 107 e 114.
} 
político, transformando destarte o modo de solucionar problemas de todo o sistema político",250.

Trata-se, contudo, como em Dewey, de uma possibilidade experiencial. No cenário pós-metafísico, nenhum esforço emancipatório pode ser inscrito numa meta-história préescrita. Também para Habermas a consolidação e o fortalecimento da democracia aparecem intimamente vinculados à sua experiência histórica, identificada, por ele, em processos discursivos de formação da opinião e da vontade, vivenciados por sujeitos concretos, no horizonte de seu mundo da vida.

A partir da experiência individual dos problemas e conflitos sociais, as biografias particulares podem entrelaçar-se numa rede comunicativa, gerando a mobilização dos atores da sociedade civil e a ocupação da esfera pública, onde tais problemas são interpretados e debatidos; soluções propostas; e opiniões públicas formadas. Tudo isso de modo a introduzir temas no sistema político, orientando sua elaboração institucional, a partir de uma atuação da sociedade civil ofensiva ao mesmo tempo em que defensiva:

\footnotetext{
"Através de uma ofensiva", eles (os movimentos sociais) tentam lançar temas de relevância para toda a sociedade, definir problemas, trazer contribuições para a solução de problemas, acrescentar novas informações, interpretar valores de modo diferente, mobilizar bons argumentos, denunciar argumentos ruins, a fim de produzir uma atmosfera consensual, capaz de modificar parâmetros legais de formação da vontade política e exercer pressão sobre os parlamentos, tribunais e governos em benefício de certas políticas. Ao passo de "defensivamente", eles tentam preservar certas estruturas da associação e da esfera pública, produzir contraesferas públicas subculturais e contrainstituições, solidificar identidades coletivas e ganhar novos espaços na forma de direitos mais amplos e instituições reformadas ${ }^{251}$.
}

E, assim, o potencial cognitivo e prático imanente ao discurso pode ser atualizado, de modo sempre renovado, num processo de aprendizagem em que as condições exigentes de sua efetivação - a situação de fala "ideal" e a competência comunicativa dos atores sociais - fortalecem-se de forma contínua, propiciando o amadurecimento progressivo dos hábitos, práticas e instituições democráticas.

${ }^{250}$ HABERMAS, Direito e democracia, Vol. 02, 2011, p. 107, 115 e 116.

${ }^{251}$ HABERMAS, Direito e democracia, Vol. 02, 2011, p 104. 
É nesse percurso de fortalecimento e consolidação da experiência da democracia, que se afirma o papel central a educação, identificada como processo comunicativo, apoiado no mundo da vida e referido à renovação de seus componentes estruturais ${ }^{252}$.

\section{Uma concepção de educação a partir de Habermas}

Como mais de uma vez mencionado, Habermas não possui uma teoria acabada e sistematizada sobre a educação. Isso, contudo, não torna desconfortante, em nenhuma medida, a referência a uma pedagogia da ação comunicativa, promotora da convivência democrática. Induzem, de forma imediata, uma teoria educacional, mesmo que não elaborada, em termos definitivos, pelo autor, a perspectiva comunicativa de racionalidade e de ação, voltadas ao entendimento e referidas ao discurso; a teoria intersubjetivista e cognitivista da ética discursiva; a concepção de desenvolvimento da consciência moral, sob o enfoque de um processo de aprendizagem; e, por fim, o modelo ampliado e exigente de democracia como práxis de autodeterminação, resultante da combinação de todas as construções teóricas antes aludidas.

Refletir sobre a educação à luz do pensamento habermasiano permite localizá-la, de modo bastante fecundo, no âmbito de uma teoria social maior, interpretando-a na linha da retomada crítica do projeto inacabado de modernidade. E, assim, concebida em termos da racionalidade que a determina, a educação pode ser analisada na perspectiva da usurpação e prevalência do momento cognitivo-instrumental da razão e da colonização do mundo da vida por imperativos sistêmicos ${ }^{253}$. Para Habermas, está claro que “A atual disputa em torno das orientações fundamentais da política educacional pode ser interpretada, no nível da teoria da sociedade, como luta a favor ou contra a colonização do mundo da vida",254

Sob tal enfoque teórico, a educação, no seu sentido mais amplo, passa a ser compreendida como espaço privilegiado do agir comunicativo, em que se preservam e podem ser ampliados (não sem resistência) processos linguísticos voltados ao entendimento. Isso, de maneira a reproduzir, desenvolver e renovar, como componentes estruturais do mundo da vida racionalizado, as tradições culturais; os padrões normativos,

\footnotetext{
${ }^{252}$ HABERMAS, Teoria do agir comunicativo, Tomo 02, p. 252 e 266.

${ }^{253}$ BOUFLEUER, Pedagogia da ação comunicativa, 2001, p. 11.

${ }^{254}$ HABERMAS, Teoria do agir comunicativo, Tomo 02, p. 667.
} 
solidários e cooperativos, de convivência social; e personalidades cognitiva e moralmente capazes $^{255}$.

Os momentos educacionais, formais e informais, remanescem como "nichos" em que é válida a aposta na autocompreensão ampliada e esclarecida da razão: em sua dimensão comunicativa, portanto. A partir deles, vislumbra-se a possibilidade da progressiva expansão da razão comunicativa a todos os momentos da interação humana destacada, aqui, a esfera pública democrática - habilitando e habituando à coordenação da ação social pela via do entendimento. Um processo experiencial de aprendizagem, enfim, em que se possa denunciar, sempre mais, o emprego da violência, velado ou não, e o uso parasitário da linguagem, reorientando a razão instrumental, como um momento subordinado apenas, àqueles limites “dentro dos quais é imprescindível e pode fornecer uma contribuição inestimável para assegurar a organização e sobrevivência das modernas sociedades de massa",256.

A pedagogia da ação comunicativa, assim cogitada, pode ser apreendida dentro das seguintes premissas e diretrizes.

3.1. O estreitamento da racionalidade ao momento cognitivo-instrumental, assim levada ao campo das interações sociais, transpôs para a relação sujeito-sujeito, a perspectiva objetivante (sujeito-objeto). O objeto cognoscível e manipulável, agora, pode ser a natureza, uma norma ou seres humanos. O passo seguinte, no qual o outro, feito objeto, torna-se res, em planos egoístas de ação orientados ao êxito, emerge como efeito patológico da realização deturpada da racionalidade, solipsista, restrita ao paradigma da filosofia da consciência, na história da modernidade ${ }^{257}$.

A reprodução desse paradigma, nos processos de socialização - que definem e institucionalizam a educação -, desliga-os da atualização do potencial comunicativo da racionalidade. Desconhece o diálogo, a interação linguística voltada ao entendimento, como experiência fundamental para processos de aprendizagem cognitiva e moral.

255 BOUFLEUER, Pedagogia da ação comunicativa, 2001, p. 17; HABERMAS, Teoria do agir comunicativo, Tomo 02, p. 252 e 253.

${ }^{256}$ FREITAG, A teoria crítica, 2004, p. 62.

257 BOUFLEUER, Pedagogia da ação comunicativa, 2001, p. 17; HABERMAS, Consciência moral e agir comunicativo, 2003, p. 42; BITTAR, Justiça e emancipação, 2011, p. 350. 
A razão centrada no sujeito, que se autoafirma no mundo objetivado, possibilitou, sim, progressos técnico-científicos, para o enfrentamento e disponibilização da natureza. Habermas não nega isso. Porém, concomitantemente, refreou a si mesma ao desconhecer o diálogo interdisciplinar e as aprendizagens que disso podem resultar. Desenvolveu-se encapsulada em culturas de especialistas ${ }^{258}$, na retalhadura cartesiana da realidade, anulando "o potencial da razão (fragmentada), que somente pensa por nichos afunilados de conhecimento, sem a capacidade re-integrativa do pensamento" 259 .

E mais, nesse percurso racional deformado, os avanços científicos e tecnológicos desligaram-se de sentidos interpretados e atribuídos comunicativamente. Voltam-se, em seu automatismo sem sentido ${ }^{260}$ (em Dewey, a instrumentalidade que se torna senhor ${ }^{261}$ ) contra o próprio homem reificado, dessignificado, ainda incapaz de promover progressos análogos no campo moral: a química de armas e gases tóxicos; a física da bomba atômica; a economia da guerra; o direito nazista; a matemática de homens "mortos ou abandonados à morte por decisão humana", vista no Século XX, mas sem precedente na história ${ }^{262}$.

Em contraposição a tudo isso, uma pedagogia da ação comunicativa há de se consolidar, necessariamente, de acordo com a ideia do diálogo, da práxis discursiva, apostando em seu sentido cognitivo e prático.

Reitera-se. A intersubjetividade da argumentação atualiza a promessa cognitiva - e moral cognitivista -, a partir de relações de entendimento. É na dialética da critica e fundamentação que podemos, superando os autoenganos a que está sujeita a razão solitária, os particularismos experienciais, assim como as dificuldades de entendimento, corrigir e renovar nossos conhecimentos teóricos e discernimentos morais ${ }^{263}$.

Disso decorre, sob o ponto de vista da relação entre os sujeitos envolvidos no processo educacional, a recusa ao caráter unilateral e impositivo do paradigma pedagógico intitulado, por Dewey, tradicional. Nesse paradigma, relido por Paulo Freire, sob a

${ }^{258}$ HABERMAS, $O$ discurso filosófico da modernidade, 2002, p. 438; HABERMAS, Consciência moral e agir comunicativo, 2003, p. 33.

${ }^{259}$ BITTAR, Justiça e emancipação, 2011, p. 77.

${ }^{260}$ HABERMAS, Teoría y praxis, 1990, p. 319.

${ }^{261}$ DEWEY, The public and its problems, 1991, p. 175.

${ }^{262}$ HOBSBAWN, Era dos extremos, 2000, p. 21.

263 HABERMAS, A ética da discussão e a questão da verdade, 2007, p. 10; HABERMAS, Verdade e justificação, 2009, p. 71; HABERMAS, Direito e democracia, Vol. 01, 2012, p. 190 e 191; HABERMAS, Teoria do agir comunicativo, Tomo 01, 2012, p. 57. 
denominação educação bancária, o processo de ensino-aprendizagem restringe-se à transmissão de conhecimentos, do educador ao educando, de forma que "a aprendizagem, nesse caso, só ocorre do lado do aluno" ${ }^{264}$. Desse modo, deturpada a bilateralidade da comunicação, "Em lugar de comunicar-se, o educador faz 'comunicados' e depósitos que os educandos, meras incidências, recebem pacientemente, memorizam e repetem" ${ }^{265}$.

O resultado de uma experiência que, assim concebida, desconhece o outro e suas experiências, valorizando a passividade, a unilateralidade, o solilóquio, não pode ser outro senão a (de)formação de uma personalidade passiva, heterônoma e egocêntrica, habituada a não mais que o restrito e empobrecido exercício monológico e objetivante da razão.

Sob a perspectiva comunicativa, o processo educativo pode ser compreendido, em contrapartida, em termos de uma experiência linguística de entendimento e, portanto, de um processo cooperativo de interpretação para definição intersubjetiva de situações referidas a fatos do mundo objetivo, normas do mundo social e vivências do mundo subjetivo $^{266}$. A "razão comunicativa produz verdades a partir do exercício da interlocução", num "processo de produção de sentido que se dá em comum entre falantes"267.

Com isso, como diálogo, a relação educacional tem de se atualizar bilateralmente, entre sujeitos, falantes e ouvintes, de forma tal que todos, destacando-se aqui os educadores, renunciem a qualquer superioridade de uma posição privilegiada. Afinal,

(...) eles próprios se veem envolvidos nas negociações sobre o sentido e a validez dos proferimentos. Ao tomarem parte em ações comunicativas, aceitam por princípio o mesmo status daqueles cujos proferimentos querem compreender. Eles não são mais imunes às tomadas de posição por sim/não dos sujeitos de experiência ou dos leigos, mas empenham-se num processo de crítica recíproca ${ }^{268}$.

A conclusão, que segue daí, merece o destaque: "No quadro de um processo de entendimento mútuo - virtual ou atual - não há nada que permita decidir a priori quem tem de aprender de quem",269.

Assegurado ao educando o direito fundamental ao por quê??, o ponto central da práxis comunicativa desloca-se da unilateralidade da "mera reprodução (repetição, cópia)

\footnotetext{
${ }^{264}$ BOUFLEUER, Pedagogia da ação comunicativa, 2001, p. 74.

${ }^{265}$ FREIRE, Paulo. Pedagogia do Oprimido. 50 ed. rev. e atual. Rio de Janeiro: Paz e Terra, p. 80.

${ }^{266}$ HABERMAS, Teoria do agir comunicativo, Tomo 01, 2012, p. 138.

${ }^{267}$ BITTAR, A discussão do conceito de direito, 2005, p. 808.

${ }^{268}$ HABERMAS, Consciência moral e agir comunicativo, 2003, p. 43.

${ }^{269}$ HABERMAS, Consciência moral e agir comunicativo, 2003, p. 43.
} 
de conhecimentos", à bilateralidade de sua apropriação crítica e fundamentada ${ }^{270}$, na experiência participativa e dialógica, que inclui o outro:

Ora, quem argumenta reconhece implicitamente cada parceiro de argumentação como alguém capaz de captar sentido e de pautar seu comportamento a partir do sentido captado (...) A abertura da linguagem a um processo de argumentação revela algo fundamental na vida humana: a argumentação pressupõe como sua condição de possibilidade, o reconhecimento recíproco de todos os seus membros como parceiros de igual direito, ou seja, o reconhecimento universal dos homens entre si como sujeitos $^{271}$.

Sob o ponto de vista do conteúdo, o conceito de discurso, aplicado à educação, demanda a fixação do diálogo interdisciplinar como premissa da organização didáticopedagógica.

Para tanto, a filosofia sobressai. Pode, na esfera educacional, desempenhar todo seu papel de mediação hermenêutica, contendo a especialização cientificista, da qual o próprio pensamento filosófico acabou vitimado, "sofisticando-se no conceito, afastando-se consequentemente da vida prática dos homens, de seu mundo vital, de seus interesses éticos, psicológicos, etc., alienando-se" ${ }^{, 272}$.

A interdisciplinaridade implica a renúncia a "grades" de disciplinas, cujas linguagens não se traduzem entre si, em favor do contato e da cooperação entre os diferentes campos do saber, consolidados sob as distintas dimensões da razão, agora reunidas em sua definição comunicativa. Desse modo, as perspectivas e experiências científicas, morais e também artísticas podem remeter umas às outras, interpenetrando interpretações cognitivas, expectativas normativas e expressões subjetivas. Tudo isso, sem perder o contato, ainda, com as questões e tematizações oriundas da prática comunicativa cotidiana, no horizonte do mundo da vida ${ }^{273}$.

Com o diálogo emancipador, reverte-se a degeneração pela singularização, pela especialização, possibilitando, na socialização, no encontro com o outro, na troca, na

${ }^{270}$ BOUFLEUER, Pedagogia da ação comunicativa, 2001, p. 77.

${ }^{271}$ OLIVEIRA, Manfredo Araújo de. Escola e sociedade: questão de fundo de uma educação libertadora. Revista de Educação AEC. Brasília, ano 18, no 71, jan/mar. 1989, p. 23.

${ }^{272}$ SIEBNEICHLER, Jürgen Habermas, 1994, p. 45.

${ }^{273}$ HABERMAS, Modernidade - um projeto inacabado, 1992, p. 116 e 119; HABERMAS, Consciência moral e agir comunicativo, 2003, p. 32 e 33. 
reciprocidade, a permanente crítica e revisão do conhecimento produzido e transmitido às novas gerações ${ }^{274}$.

3.2. A participação em discursos, como destacado, passa pelo exigente pressuposto da competência comunicativa, em nenhuma medida inata à personalidade. Não se espera de uma criança as habilidades e o inventário racional necessários para a práxis da argumentação racional, com o educador, em que pretensões de validade são criticadas e argumentos apresentados, na construção de um entendimento. Isso é o resultado, não o ponto de partida, de um processo de aprendizagem, de formação social da identidade.

Dessa forma, a pedagogia da ação comunicativa, ambientada no diálogo e orientada à sua efetivação, em seu melhor sentido cognitivo e prático, corresponde a um processo de desenvolvimento cognitivo e moral.

Envolve a gradual construção e reconstrução linguística, pelo sujeito em crescimento - com base em seus recursos cognitivos, em permanente reorganização criativa -, de um mundo subjetivo, descortinando e ingressando, concomitantemente, nos mundos objetivo e social. É no percurso de descoberta e reelaboração, com cada vez mais significação, dos objetos e relações intersubjetivas experienciados, que a pessoa em crescimento vai construindo seus instrumentos de pensamento mais adequados para apreendê-los ${ }^{275}$.

Destarte, citando Sérgio Alexandre da Rocha, Boufleuer ressalta a impropriedade de uma situação ideal de fala nos níveis mais elementares do processo educacional: "por hipótese, o instrutor sabe e ensina, e o educando aprende (...) o educando não problematiza a verdade; ele a recebe". Afinal, o sujeito em crescimento precisa, antes, suficientemente, ingressar no universo linguístico e participar da experiência de vida compartilhada. Para que possa, no momento seguinte, produzir, de forma sempre mais competente, uma argumentação racional, "é necessário que quem a produz participe do consenso estabelecido em alguma medida, sem o que não haveria linguagem para formular essa mesma argumentação" 276 .

\footnotetext{
${ }^{274}$ HABERMAS, Verdade e justificação, 2009, p. 96.

${ }^{275}$ FREITAG, A questão da moralidade, 1989, p. 13.

${ }^{276}$ BOUFLEUER, Pedagogia da ação comunicativa, 2001, p. 78.
} 
Todavia, já aqui há, do lado do educador, uma mudança de perspectiva fundamental: a sabedoria e experiência que transmite não o imuniza da condição de participante da interação linguística em construção. Seu papel educador se ampara, apenas, “em ser ele o porta-voz de consenso já estabelecido acerca de determinados fatos, inclusive os triviais, e das regras com eles compatíveis de uso de linguagem"277.

Com isso, apesar da distância entre os participantes, em termos de experiências e habilidades cognitivas e comunicativas, forma-se uma ambiência que é plenamente compatível com discurso, na medida em que o antecipa. Afinal, pressupõe a validade do consenso transmitido, apenas, "até que se produzam argumentos em contrário",278.

Assim, integrando o universo linguístico e o horizonte de um mundo da vida racionalizado, o educando pode, pouco a pouco, aquilatar a atitude hipotética diante da qual,

(...) as coisas e eventos transformam-se em estados de coisas que tanto podem existir como não existir; do mesmo modo, as normas existentes, isto é, de fato reconhecidas ou socialmente válidas, transformam-se em normas que tanto podem ser válidas, isto é, dignas de reconhecimento, como também inválidas ${ }^{279}$.

E pode, então, formar sua identidade pessoal num processo educacional que envolve a capacitação para assim como a participação habitual em processos linguisticos de entendimento. Uma educação, portanto, orientada ao desenvolvimento de personalidades cognitivamente competentes não só numa dada ciência ou especialidade, mas, principalmente, no sentido moral pós-convencional, construído no discurso.

3.3. Assim configurada, a educação toma forma orientada à reprodução e renovação dos componentes estruturais do mundo da vida racionalizado. E, desse modo, fomentando a comunicação orientada ao entendimento mútuo, a partir de sua experiência, pode atuar, enfim, na descolonização do mundo da vida pelos imperativos e processos não pedagógicos provenientes dos sistemas econômico e político ${ }^{280}$.

\footnotetext{
277 BOUFLEUER, Pedagogia da ação comunicativa, 2001, p. 78.

${ }^{278}$ BOUFLEUER, Pedagogia da ação comunicativa, 2001, p. 78.

${ }^{279}$ HABERMAS, Consciência moral e agir comunicativo, 2003, p. 193.

280 BOUFLEUER, Pedagogia da ação comunicativa, 2001, p. 90; HABERMAS, Teoria do agir comunicativo, Tomo 02, 2012 p. 587 e 667.
} 
Nessa referência ao mundo da vida, podem ser identificadas, como grandes tarefas educacionais, a reprodução cultural de forma racional; a integração social solidária e cooperativa; e a socialização, enquanto formação de identidades pessoais cognitiva e moralmente competentes ${ }^{281}$, fomentando e recuperando a autonomia crítica dos sujeitos.

Não se trata, portanto, à evidência, de mera repetição, continuidade, reprodução invariável. A "individuação que se torna possível pela socialização"282, ainda que constitua o sujeito, num primeiro momento, convencional e heteronomamente, não se restringe, absolutamente, a sua padronização; não esmaga a individualidade. Na referência a Mead:

O fato de todos os "si mesmos" serem constituídos por meio ou em termos de processo social e constituírem reflexos individuais dele (...) não é de maneira nenhuma incompatível com, ou destrutivo de, o fato de que cada "si mesmo" individual tem sua individualidade peculiar, seu próprio padrão único ${ }^{283}$.

Pois a personalidade, refletindo de um ponto de vista idiossincrático, único, os valores, atitudes e crenças comuns, incorporados na interação social, reage, por sua vez, criativamente, em alguma medida, sobre as tradições e as experiências sociais das quais emerge. Nesse sentido, "Há sempre uma relação mútua entre o indivíduo e a comunidade em que vive" ${ }^{284}$. Em termos habermasianos:

À medida que os participantes da interação se entendem entre si sobre a
situação concreta, encontram-se numa tradição cultural, a qual renovam à
proporção que se servem dela; enquanto os participantes da interação
coordenam suas ações pelo reconhecimento intersubjetivo de pretensões
de validade criticáveis, eles se apoiam em pertenças a grupos sociais, o
que fortalece sua integração; à proporção que as crianças tomam parte em
interações com pessoas de referência dotadas da competência de agir, elas
internalizam as orientações axiológicas de seu grupo social e adquirem
capacidades de ação generalizadas

Sendo assim, a pedagogia da ação comunicativa fomenta um processo educativo que traz consigo o aguilhão autocrítico ${ }^{286}$, renovador dos atores, interações e instituições que movimenta. Implica, como destaca Boufleuer, citando Mário O. Marques, "um alargamento do horizonte cultural, relacional e expressivo", que aparece na permanente revisão criativa dos saberes e tradições culturais, das formas de convivência e integração

281 BOUFLEUER, Pedagogia da ação comunicativa, 2001, p. 56; HABERMAS, Teoria do agir comunicativo, Tomo 02, 2012, p. 252, 253 e 260.

${ }^{282}$ HABERMAS, Teoria do agir comunicativo, Tomo 02, 2012, p. 78.

${ }^{283}$ MEAD, Mind, self and society, 1992, p. 201.

${ }^{284}$ MEAD, Mind, self and society, 1992, p. 201, 215 e 309.

${ }^{285}$ HABERMAS, Teoria do agir comunicativo, Tomo 02, 2012, p. 252.

${ }^{286}$ HABERMAS, Direito e democracia, Vol. 02, 2011, p. 228. 
social, dos mecanismos socializantes por meio dos quais personalidades são formadas e, enfim, dos modos de pensar, agir e conviver de cada $u^{287}$.

Em aludido processo de aprendizagem, entrevê-se a atuação da educação na descolonização do mundo da vida. E isso, sob duas perspectivas complementares.

Habermas, não permite o descuido de se perder de vista que a educação, instituída socialmente, está, inevitavelmente, submetida aos imperativos sistêmicos. Mas identifica, também, nos ambientes em que se desenvolve, o agir comunicativo, sem o qual a tarefa educativa não se realiza ${ }^{288}$. Assim, sob um ângulo interno, a ampliação dos espaços comunicativos, no cotidiano da práxis educacional, possibilita que, ao abrigo de sua própria experiência sempre renovada, a linguagem voltada ao entendimento adquira gradualmente primazia como padrão de interação, definidor dos conteúdos e práticas no mundo social (democrático) da educação. Pode, então, sobrepor-se aos enfoques sistêmicos, incluindo o fim lucrativo, a organização hierárquica e burocrática da estrutura educacional, as demandas imediatistas das organizações empresariais e do mercado de trabalho, as pressões e interesses de poder político $^{289}$.

O outro ângulo é o da sociedade em que o processo educacional tem lugar e para a qual espraia em seus efeitos. As experiências educacionais orientadas pelo agir comunicativo que "tornam um sujeito capaz de falar e agir - e, portanto, que o colocam em condições de participar de processos de entendimento" ${ }^{, 290}$, não o fazem restritivamente para momentos educacionais institucionalizados. Dispõem racionalmente a isso, em todas as esferas da vida social. A educação, desse modo, pode-se dizer, atualiza-se com a experiência fundamental de entrada e de preparação para a entrada no espaço público ${ }^{291}$.

E, assim, numa correlação de enriquecimento mútuo, o agir comunicativo, a partir do qual a personalidade é formada, esparrama-se - levado pelos sujeitos formados comunicativamente - à interação social, de um modo geral. Orienta-a ao entendimento mútuo e subordina, à dinâmica comunicativa, a racionalidade e os mecanismos que

\footnotetext{
${ }^{287}$ BOUFLEUER, Pedagogia da ação comunicativa, 2001, p. 57.

${ }^{288}$ HABERMAS, Teoria do agir comunicativo, Tomo 02, 2012, p. 668.

${ }^{289}$ BITTAR, Eduardo C. B. O direito na pós-modernidade (e reflexões frankfurtianas). $2^{\mathrm{a}}$ ed. rev. atual. e amp. Rio de Janeiro: Forense, 2009, p. 381.

${ }^{290}$ HABERMAS, Teoria do agir comunicativo, Tomo 02, 2012, p. 253.

291 ALMEIDA, Guilherme de Assis. Aula ministrada na disciplina Direitos humanos fundamentais do Programa de Pós-Graduação Stricto Sensu em Direito da Universidade de São Paulo. São Paulo, 29/04/2013.
} 
determinam a organização da sociedade sob a ótica sistêmica (a administração pública, o mercado capitalista, o direito). A coordenação linguística da ação social, por sua vez, induz a promoção qualitativa e quantitativa de espaços educacionais, coadunados com a reprodução simbólica dos componentes estruturais do mundo da vida racionalizado. Com isso, "em vez de uma colonização do mundo da vida pela racionalidade sistêmicoinstrumental, teremos um sistema condicionado e legitimado pela racionalidade comunicativa, própria do mundo da vida" ${ }^{292}$.

Trata-se, não há dúvida, de um processo complexo, árduo, delicado de aprendizagem, sem metagarantias de êxito. Opõe duas formas de integração social. E não desconhece que, na sociedade moderna, tem prevalecido, sobre o entendimento linguístico, a integração sistêmica que dispensa a linguagem e admite, na ação estratégica, o enfoque objetivador da sociedade e do outro reificado ${ }^{293}$.

A reversão da colonização do mundo da vida passa, assim, pela sua renovação, sob a racionalidade e do agir comunicativo, num cenário experiencial precário em que tal perspectiva claudica. Não há saída metafísica, além dos esforços dos próprios homens que se educam. Nesse contexto, envolve aprendizagens - pode-se dizer, no continuиm experiencial deweyano - que passam por mudanças profundas no olhar sobre as tradições culturais que são reproduzidas; na forma de se interagir socialmente; e nos contornos, estimulados pelos processos de socialização, da individualidade.

3.4. Sob tal perspectiva, em que fica claro que a educação não pode ser tragada pelo sistema político, tampouco pelo econômico, ganha destaque a participação da sociedade civil.

A educação não pode ser tratada como exclusividade do Estado, muito menos como propriedade privada. Ante sua significação social para a renovação da cultura e da sociedade e para a formação da personalidade, ela acompanha o fluxo da comunicação, nas sociedades democráticas. Com isso, tem seu lugar na esfera privada e na esfera pública,

\footnotetext{
${ }^{292}$ BOUFLEUER, Pedagogia da ação comunicativa, 2001, p. 96.

${ }^{293}$ PINZANI, Habermas, 2009, p. 111; HABERMAS, Teoria do agir comunicativo, Tomo 02, 2012, p. 279 e 281.
} 
complementares entre $\mathrm{si}^{294}$. Faz-se, mesmo, já se disse, como locus de preparação e entrada na vida pública.

A partir desses espaços, privados e públicos, pode-se pensar a "estruturação pedagógica da educação", restringindo os influxos sistêmicos e implementando a descolonização do mundo da vida ${ }^{295}$.

Isso, seja por meio da educação promovida por agentes e associações não estatais e não econômicas, seja por meio da participação ativa e consistente da sociedade civil na definição, organização e execução das políticas e programas educacionais, libertando-a de demandas e pressões do poder político e da burocracia. De qualquer forma, em qualquer espaço pedagogicamente concebível, impondo limites à instrumentalização da educação pela lógica do capital, do dinheiro, do lucro.

3.5. Por tudo isso, pensar a educação, a partir de Habermas, implica apoiá-la no diálogo e ressaltar, no processo social de formação da individualidade, a consolidação, de modo sempre mais enriquecido de sentido, dos potenciais cognitivos e práticos imanentes à comunicação linguística voltada ao entendimento.

Dessa forma, a pedagogia da ação comunicativa caminha, de modo bastante próximo à filosofia educacional progressiva de Dewey, na direção de uma educação para a qual o desenvolvimento cognitivo e moral dos sujeitos dá no mesmo que a preparação para a democracia. Afinal, de tudo o que fora apreendido, extrai-se que, configurada discursivamente, a democracia projetada por Habermas também pode ser lida, adequadamente, na linguagem deweyana, como modelo social e moral, em que se pode atualizar, na comunicação impregnada de potencial cognitivo e consumatório, a autonomia que resulta da formação social bem sucedida da individualidade, tornando-a "mais racional, mais social e, finalmente, mais moral" ${ }^{296}$.

No percurso formativo, o sujeito atualiza sua racionalidade, em seu significado mais autêntico e profundo - qual seja, o comunicativo -, na práxis argumentativa, primeiro, nos espaços institucionais da educação; depois, nas demais esferas de interação

\footnotetext{
${ }^{294}$ HABERMAS, Teoria do agir comunicativo, Tomo 02, 2012, p. 576 e 577.

${ }^{295}$ HABERMAS, Teoria do agir comunicativo, Tomo 02, 2012, p. 667.

296 DEWEY, The public and its problems, 1991, p. 83 e 218; BERNSTEIN, The resurgence of pragmatism, 1992, p. 814 e 815; DEWEY, John. Ethics. The Later Works 1925-1953. Volume 07 (1932). Edited by Jo Ann Boydston. Southern Illinois University, 2008, p. 12 e 13.
} 
social, destacando-se, aqui, a esfera pública democrática, ela mesma, por excelência, medium educacional da vida solidária, racionalmente guiada.

A pedagogia da ação comunicativa efetiva-se, enfim, como educação na e para a convivência democrática. Envolvendo a experiência da participação ${ }^{297}$, da inclusão do outro, na participação na experiência do diálogo, pode marcar fundo, na subjetividade, que "agir no mundo é sobretudo inter-agir com o outro, a partir da consideração do outro" 298.

Permite experienciar e promover a democracia, para além da dimensão políticosistêmica, como espaço racional-comunicativo em que, no respeito ao outro, na renúncia à violência, no pluralismo, na igualdade de condições de participação, na efetividade dos direitos humanos, na solidariedade, efetiva-se, a partir do mundo da vida racionalizado, o projeto moderno revisitado de emancipação.

${ }^{297}$ KOHLBERG, La democracia en la escuela secundaria, 1992, p. 17.

${ }^{298}$ BITTAR, O direito na pós-modernidade, 2009, p. 397 e 398. 


\section{EDUCAČ̃̃ PARA A DEMOCRACIA NO BRASIL: APROXIMAÇÕ̃ES ENTRE JOHN DEWEY E JÜRGEN HABERMAS}

Democracia e educação são inscritas, na Constituição Federal de 1988, de modo bastante vigoroso. A primeira adjetiva a República, constituindo-a, já no dispositivo inaugural, como Estado Democrático de Direito. A segunda, compondo, como direito social fundamental, o conteúdo da dignidade humana - erigida a fundamento do Estado -, é tratada com grande desvelo em seção própria. Visa, nos termos do Art. 205, ao pleno desenvolvimento da pessoa, à qualificação para o trabalho e ao preparo para o exercício da cidadania. E, assim, volta-se, ante este último escopo mencionado, à promoção da organização democrática da sociedade ${ }^{1}$. Está prevista, constitucionalmente, a educação para a democracia.

\footnotetext{
${ }^{1}$ RANIERI, Nina Beatriz Stocco. O estado democrático de direito e o sentido da exigência de preparo para o exercício da cidadania, pela via da educação. Tese apresentada para inscrição em concurso visando a obtenção do título de Livre-docente, junto ao Departamento de Direito de Estado da Faculdade de Direito da Universidade de São Paulo. São Paulo, 2009, p. 380.
} 
A partir daí, ambas são preenchidas de conteúdos que passam por todos os âmbitos da experiência comunicativa do direito, compondo, renovando e efetivando - em leis, regulamentos, atos administrativos, políticas públicas, decisões judiciais e, também, na convivência do dia a dia - versões discursivas que "constroem os objetos sobre os quais se discorre",

Falar em democracia e em educação, apoiando-se na filosofia social de John Dewey e Jürgen Habermas, exige o olhar atento sobre essa experiência, no horizonte do mundo da vida, em que os significados das instituições são formados e reconstruídos hermeneuticamente, a partir das tradições e dos hábitos culturais - também em permanente transformação. Tudo isso, numa práxis histórico-cultural que "vive e revive quotidianamente o sentido jurídico"”.

O texto constitucional não é um objeto inerte tampouco unívoco. É, muito mais, um projeto de sentidos que refletem, dialeticamente, a ambiência social da qual emergem ${ }^{4}$. Quanto à qualidade desse trabalho hermenêutico, na perspectiva comunicativa dos dois filósofos, pode ser medida pelo nível mais ou menos racional-discursivo de sua elaboração pela "comunidade de intérpretes"5 (legisladores, aplicadores, juízes, destinatários, etc.).

Sendo assim, pensar a democracia e a educação para sua consolidação não permite o descuido de se perder de vista o lugar do qual se fala. No contexto brasileiro, implica refletir sobre a construção de um sentido sobre o chão de uma história de inexperiência da democracia e de profundo desrespeito aos direitos humanos.

Trata-se de um passado pesado ${ }^{6}$ que, no continuum experiencial, faz-se, ainda, muito presente. No processo de aprendizagem da democracia, a partir de sua própria experiência incipiente, convivem com a ordem jurídica constituída em 1988, na esfera da sociedade civil, o frágil engajamento comunicativo ${ }^{7}$ combinado com a cidadania meramente eleitoral; no âmbito do sistema político, práticas autoritárias, paternalistas e

${ }^{2}$ HESPANHA, António Manuel. O caleidoscópio do direito. O direito e a justiça nos dias e no mundo de hoje. $2^{\mathrm{a}}$ ed. Coimbra: Almedina, 2009, p. 657.

${ }^{3}$ BITTAR, Eduardo C. B. Linguagem jurídica. $5^{\text {a }}$ Ed. São Paulo: Saraiva, 2010, p. 142.

${ }^{4}$ BITTAR, Linguagem jurídica, 2010, p. 124 e 125.

${ }^{5}$ HESPANHA, $O$ caleidoscópio do direito, 2009, p. 671.

${ }^{6}$ FAORO, Raymundo. Os donos do poder. Formação do patronato político brasileiro. Volume 02. $11^{\underline{a}}$ Ed. São Paulo: Globo, 1995, p. 748.

${ }^{7}$ BITTAR, Eduardo C. B. A discussão do conceito de direito: uma reavaliação a partir do pensamento habermasiano. Boletim da Faculdade de Direito. Universidade de Coimbra. Vol. LXXXI, 2005, p. 808. 
patrimonialistas, avessas à república e à democracia; no distanciamento entre ambos, relações caracterizadas pela verticalidade, pelo não diálogo ${ }^{8}$.

Nesse passo, tem-se exigido pouco, um mínimo procedimental, para a adjetivação da organização social como democrática. Os sentidos desfocam, refratam, distorcem, obscurecem o texto constitucional ${ }^{9}$. Restringe-se a leitura enriquecida que a experiência democrática, constitucionalmente arquitetada, pode compreender.

É diante desse cenário que, com o amparo da filosofia social de Dewey e de Habermas, são descortinadas perspectivas hermenêuticas às instituições e procedimentos democráticos e educacionais, alinhadas com a tradição da modernidade, revisitada criticamente. Tradição que, afinal, inscreveu a democracia e a educação na Constituição.

Abrem-se horizontes de experimentação social e política, sob o Estado Democrático de Direito, que, orientados à práxis emancipatória, partem do reconhecimento da incompletude dinâmica de nosso percurso histórico. Buscam, para além de entender os fracassos, aprender com os desacertos, valendo-se, também, dos progressos e instrumentais proporcionados pela modernidade ${ }^{10}$.

1. A Constituição Federal de 1988 coaduna-se, como visto, com o projeto moderno de emancipação.

Toma o homem e sua dignidade como valor-fonte de toda experiência jurídica ${ }^{11}$, fundamento e fim da organização estatal ${ }^{12}$. Reconhecendo extensas propriedades caracterizadoras do ser humano ${ }^{13}$, incorpora, de forma robusta, todas as três dimensões dos

${ }^{8}$ RANIERI, $O$ estado democrático de direito e o sentido da exigência de preparo para o exercício da cidadania, pela via da educação, 2009, p. 385; BITTAR, Eduardo C. B. O direito na pós-modernidade (e reflexões frankfurtianas). $2^{\underline{a}}$ ed. rev., atual. e amp. Rio de Janeiro: Forense Universitária, 2009, p. 215.

${ }^{9}$ HESPANHA, $O$ caleidoscópio do direito, 2009, p. 658.

${ }^{10}$ HABERMAS, Jürgen. Modernidade - um projeto inacabado. In ARANTES, Otília B. Fiori e ARANTES, Paulo Eduardo. Um ponto cego no projeto moderno de Jürgen Habermas: arquitetura e dimensão estética depois das vanguardas. São Paulo: Brasiliense, 1992, p. 118; BENEVIDES, Maria Victoria de Mesquita. $A$ cidadania ativa. Referendo, plebiscito e iniciativa popular. 3a ed. São Paulo: Ática, 2003, p. 196; MOTA, Carlos Guilherme. Viagem incompleta. A experiência brasileira. Formação: histórias. 3ª ed. São Paulo: Editora SENAC, 2009, p. 23.

${ }^{11}$ LAFER, Celso. A reconstrução dos direitos humanos: um diálogo com o pensamento de Hannah Arendt. São Paulo: Cia das Letras, 1988, p. 15 e 19.

${ }^{12}$ PIOVESAN, Flávia. Temas de direitos humanos. $2^{\mathrm{a}}$ ed. rev. amp. e atual. São Paulo: Max Limonad, 2003, p. 339; SARLET, Ingo Wolfgang. Dignidade da pessoa humana e direitos fundamentais na Constituição Federal de 1988. Porto Alegre: Livraria do advogado, 2011, p. 91.

${ }^{13}$ HONNETH, Axel. Luta por Reconhecimento. A gramática moral dos conflitos sociais. $2^{2}$ ed. São Paulo: Editora 34, 2009, p. 188. 
direitos fundamentais: as cinco categorias afirmadas por Habermas, à luz do conceito de discurso $^{14}$. Protege a vida, a privacidade, a propriedade, a segurança, a igualdade, conferindo amplo campo de liberdades subjetivas (liberdade de pensamento, de expressão, de atividade intelectual, de trabalho, de associação, dentre outras). Prevê direitos processuais (ampla defesa, contraditório, devido processo legal, etc.). Resguarda a pertença ao Estado (direitos de nacionalidade). Assegura direitos sociais, como educação, moradia, saúde, trabalho, previdência e assistência social. Protege os direitos transindividuais ao meio ambiente equilibrado, à preservação da cultura e ao desenvolvimento científico e tecnológico. E estabelece, finalmente, direitos de participação política.

Garantindo a constituição racional da personalidade, tais direitos são integrados, sob o princípio da soberania popular, ao Estado Democrático de Direito. E, desse modo, direciona uma práxis de autogoverno, de autolegislação, em que os sujeitos de direito, renunciando ao uso da violência e da arbitrariedade, movem-se num medium jurídico do qual são também autores ${ }^{15}$.

Para sua efetivação, o regime democrático, de acordo com a Constituição Federal, é semidireto. Combina procedimentos de representação, com as eleições periódicas dos representantes políticos integrantes dos Poderes Executivo e Legislativo, e mecanismos de participação direta (plebiscito, referendo e iniciativa popular). Mas seu dever ser não se esgota aí. Não se trata de uma configuração pronta, “congelada”. Afinal, a organização constitucional democrática do Estado brasileiro irradia a outros momentos e espaços sociais que precedem, envolvem e vão além de tais instrumentos ${ }^{16}$. O próprio texto constitucional, aliás, dá exemplo disso, no campo da educação, ao tratar da gestão democrática do ensino público (Art. 206, inciso IV). A democracia, nesse sentido, pode significar, além da "mera ocupação de espaços já existentes anteriores à prática dos sujeitos políticos", a criação, reconstrução e ocupação de múltiplos espaços públicos para a participação popular ${ }^{17}$.

Projeta-se, assim, a emancipação, que, ambientada na democracia e apoiada em amplo rol de direitos fundamentais, não opõe indivíduo (eu) e sociedade (nós). Induz,

\footnotetext{
${ }^{14}$ HABERMAS, Jürgen Direito e democracia: entre factibilidade e validade. Volume 01. 2 ${ }^{-}$ed. Trad. Flávio Beno Siebeneichler. Rio de Janeiro: Tempo Brasileiro, 2012, p. 159 e 160.

${ }^{15}$ HABERMAS, Direito e democracia, Vol. 01, 2012, p. 159.

16 BENEVIDES, A cidadania ativa, 2003, p. 15, 18 e 19; SILVA, José Afonso da. Curso de direito constitucional positivo. 33를 $\mathrm{ed}$ rev. e atual. São Paulo: Malheiros, 2010, p. 110.

${ }^{17}$ BENEVIDES, A cidadania ativa, 2003, p. 19.
} 
antes, entre eles, uma complementaridade fundamental ${ }^{18}$. Resguarda-se, no plano jurídicoconstitucional, a formação da individualidade e a esfera de autonomia privada, garantindo, ao mesmo tempo, a participação política na formação racional da opinião e da vontade.

Promulgado na virada para o Século XXI, o ordenamento constitucional direciona um caminho pelo qual podem ser evitados os extremos que marcaram a história do breve Século $\mathrm{XX}^{19}$. Afasta-se do individualismo e abstencionismo estatal liberal, que levou ao totalitarismo de mercado, impedindo "por completo a formação de uma identidade coletiva". Isso, sem cair, na outra ponta, na hipertrofia, no paternalismo, no totalitarismo do Estado, que sufocou a individualidade: a "visão do coletivismo que absorve por completo a esfera do indivíduo" ${ }^{20}$.

A Constituição justifica, nessa linha, sua compreensão dinâmica, como projeto (de país) inacabado de sentido que, no curso do projeto inacabado de modernidade, funciona e se enriquece na medida em que é atualizado ${ }^{21}$. A filosofia social de Dewey e a de Habermas apresentam contributos bastante frutíferos nessa tarefa. Permitem, como destaca o segundo, apreender o Estado Democrático de Direito, sim, como empreendimento "arriscado, delicado e, especialmente falível e carente de revisão", mas que, também, "tende a reatualizar, em circunstâncias precárias, o sistema de direitos, o que equivale a interpretá-los melhor e institucionalizá-los de modo mais apropriado e a esgotar de modo mais radical o seu conteúdo"22.

2. Tudo isso, debruçando-se sobre um texto constitucional promulgado no curso de um processo histórico de inexperiência da democracia e da cultura de direitos humanos. Cumpre rememorar. A Constituição marca, na história da democracia no Brasil - curta e entrecortada por golpes e regimes autoritários - a afirmação de instituições com ela

\footnotetext{
${ }^{18}$ HABERMAS, Direito e democracia, Vol. 01, 2012, p. 201; DEWEY, John. The public and its problems. Swallow Press/Ohio University Press/Athens, 1991, p. 151; BITTAR, Eduardo C. B. Justiça e emancipação: reflexões jusfilosóficas a partir do pensamento de Jürgen Habermas. Tese apresentada em concurso de Professor Titular junto ao Departamento de Filosofia e Teoria Geral do Direito da Faculdade de Direito da Universidade de São Paulo. São Paulo, 2011, p. 655.

${ }^{19}$ HOBSBAWN, Eric. Era dos extremos. O breve século XX: 1914-1991. $2^{\text {a }}$ ed. Trad. Marcos Santarrita. Rev. Téc. Maria Célia Paoli. São Paulo: Cia das Letras, 2000.

${ }^{20}$ BITTAR, Justiça e emancipação, 2011, p. 489.

${ }^{21}$ BITTAR, Linguagem jurídica, 2010, p. 125.

${ }^{22}$ HABERMAS, Jürgen Direito e democracia: entre factibilidade e validade. Volume 02. Trad. Flávio Beno Siebeneichler. Rio de Janeiro: Tempo Brasileiro, 2011, p. 119.
} 
condizentes e de um sistema vigoroso de direitos ${ }^{23}$. Rompe com os vinte anos de discurso cínico da Ditadura Militar, em relação à experiência democrática ${ }^{24}$, e de uso do ordenamento jurídico como instrumento autoritário de coordenação social ${ }^{25}$. Opõe-se, enfim, a um passado que sobrecarrega o presente de tarefas democratizantes.

Ocorre que, se não dispensa a institucionalização jurídica de mecanismos e procedimentos que lhe dê amparo, a democracia não adquire sentido ampliado e profundo como reflexo imediato e necessário de leis. O fim da Ditadura e a vigência jurídica da nova ordem não significaram a consolidação, muito menos o esgotamento do projeto constitucional que os antecedentes históricos negaram ou, simplesmente, não puderam sedimentar $^{26}$.

Nesse ponto, a perspectiva meadiana da constituição social da individualidade, presente em Dewey e Habermas, é esclarecedora. Demonstra que os hábitos de pensar, agir e interagir são constituídos comunicativamente, em interação com o outro. É pela mediação da linguagem - e, com ela, da tradição cultural, dos padrões normativos e das orientações axiológicas do grupo social - que a personalidade surge como um objeto para si mesmo $^{27}$. O mundo da vida no qual se está inserido e as formas de vida que o conformam, internalizados pelo sujeito, determinam experiencialmente, até certo ponto, o olhar sobre o mundo e o modo como pensará e atuará. No contexto brasileiro, isso implica, em grande medida, nas "idas e vindas" do processo democrático ${ }^{28}$, o avesso da democracia e do respeito aos direitos humanos que esta supõe e atualiza.

Tal é a estrutura convencional da personalidade (o me), fruto da socialização, que, sem poder ser simplesmente apagada, forma, em Mead, a moldura do eu:

\footnotetext{
${ }^{23}$ PIOVESAN, Temas de direitos humanos, 2003, p. 339.

${ }^{24}$ WEFFORT, Francisco C. Por que democracia? $2^{\mathrm{a}}$ ed. São Paulo: Brasiliense, 1984, p. 33; VIOLA, Sólon Eduardo Annes. Direitos humanos no Brasil: abrindo portas sob neblina. In SILVEIRA, Rosa Maria Godoy e outros (org.). Educação em direitos humanos: Fundamentos teórico-metodológicos. João Pessoa: Editora Universitária, 2007, p. 127.

${ }^{25}$ LAFER, A reconstrução dos direitos humanos, 1988, p. 78.

26 DUARTE, Nestor. A ordem privada e a organização política nacional, São Paulo/Rio de Janeiro/Recife/Porto Alegre: Companhia Editora Nacional, 1939, p. 221 e 222; BENEVIDES, Maria Victoria de Mesquita. Em defesa da república e da democracia. In BENEVIDES, Maria Victoria de Mesquita; BERCOVICI, Gilberto; MELO, Claudinei de. Direitos humanos, democracia e república: homenagem a Fábio Konder Comparato. São Paulo: Quartier Latin, 2009, p. 727.

${ }^{27}$ MEAD, George Herbert. Mind, self and society: from the standpoint of a social behaviorist. Edited and with a introduction by Charles W. Morris. Chicago/London: The University of Chicago Press, 1992, p. 225 e 253.

${ }^{28}$ FREIRE, Paulo. Educação como prática de liberdade. 14ํㅡㄹ Ed. Rio de Janeiro: Paz e Terra, 2011, p. 89.
} 
(...) o indivíduo, não importa quão original ou criativo possa ser no seu pensamento ou comportamento, assume, sempre e necessariamente uma relação definitiva - que reflete na estrutura de seu ego ou personalidade com o padrão organizado geral da experiência e com a atividade exibida ou característica do processo social de vida em que está envolvido e do qual seu ego ou personalidade é essencialmente uma expressão ou personificação criativa. Nenhum indivíduo tem uma mente que opera simplesmente em si mesma, isolada do processo de vida social do qual emergiu $^{29}$.

$\mathrm{O} e u$, por sua vez, não fica passivo. Como lembra Dewey, nem o ajustamento adaptativo é totalmente passivo em relação ao ambiente: "Mesmo um molusco atua sobre o ambiente e o modifica em alguma medida" ${ }^{, 30}$. O eu reagirá, com maior ou menor nível de novidade, de forma mais ou menos racional $^{31}$.

Nesse sentido, as experiências que tecem o processo de vida são concebidas, pela teoria deweyana, como a interação contínua e próxima entre o sujeito e seu ambiente linguisticamente apreendido. Atuando um sobre o outro, ambos, em alguma extensão, situação e agente, são modificados. Nesse continuum, que reflete o conteúdo da existência humana, o modo como a experiência vai se configurando historicamente, dentro de certas tradições, valores e instituições, direciona os horizontes de possibilidades experienciais do sujeito, que, então, reflete e (re)age sobre o ambiente comunicativo do qual emergiu. Alimenta o processo de reconstrução das experiências humanas ${ }^{32}$.

É nessa linha, aliás, que, defendendo a tradição pragmatista norte-americana, Dewey diz que não se limita a repetir e "glorificar" as tendências do ambiente social em que se insere. No entanto, em seu "protesto", não deixa, absolutamente, de assimilar aspectos da "vida de seu tempo",33.

Diante disso, na cognição do texto constitucional e da sociedade brasileira que vislumbra para o futuro, os atores sociais trazem consigo o passado habitual, inexperiente

${ }^{29}$ MEAD, Mind, self and society, 1992, p. 222.

${ }^{30}$ DEWEY, John. Reconstruction in philosophy. Mineola/New York: Dover Publication, 2004, p. 48 e 49.

${ }^{31}$ MEAD, Mind, self and society, 1992, p. 175 e 209.

32 DEWEY, Reconstruction in philosophy, 2004, p. 49; DEWEY, John. Experiência e natureza. In DEWEY, John Experiência e natureza; Lógica: a teoria da investigação; A arte como experiência; Vida e educação; Teoria da vida moral. Trad. Murilo Otávio Rodrigues Paes Leme, Anísio S. Teixeira e Leônidas Gontijo de Carvalho. Coleção Os Pensadores. São Paulo: Abril Cultural, 1980, p. 52; TEIXEIRA, A pedagogia de Dewey, 1980, p. 113 e 115.

${ }^{33}$ DEWEY, John. O desenvolvimento do pragmatismo americano. Trad. Renato Rodrigues Kinouchi. Scientiae Studia. São Paulo, v. 5, $\mathrm{n}^{\mathrm{o}}$ 2, junho/2007, p. 230. Disponível em: http://www.scielo.br/scielo.php?script=sci_arttext\&pid=S1678-31662007000200006\&lng=en\&nrm=iso. Acesso em 06/06/2014, p. 242 
da democracia. Utilizam os "velhos" instrumentos, recursos cognitivos e morais a partir dele construídos, inclusive para a formulação e assimilação de novas ideias. Deles não se livram facilmente. Muito menos de uma vez só ${ }^{34}$.

Por outro lado, não estão presos, inexoravelmente, a eles. O enriquecimento dos significados da democracia constitucionalmente afirmada, superando o passado antidemocrático, passa, então, pela construção de novos hábitos, atitudes e práticas, a partir da continuidade de sua experiência renovada. A experiência social democrática (e seu conteúdo hermenêutico) aparece numa correlação de influência recíproca com os hábitos democráticos de pensar, agir e conviver. Um pressupõe e enriquece o outro.

A consolidação da democracia exige, por isso, para além de sua constituição jurídica, a relação experiencial e processual de "mútua projeção e implicação" entre ego e alter, em função da qual "as conquistas institucionais e sociais repercutem na dimensão da vida dos indivíduos e as conquistas dos indivíduos podem reverberar em aquisições significativas para a vida coletiva" ${ }^{35}$. Implica atitudes e hábitos que, formados na dialética experiencial entre individualidade e ambiente, consolidam-se $\mathrm{em}$ e se renovam a partir de momentos, espaços e instituições sociais.

Não há - e a história do Brasil é testemunho disso - natureza humana democrática, para a qual o sujeito tenda, como também não há disposição inata no sentido inverso do autoritarismo $^{36}$. A personalidade democrática decorre de processos de aprendizagem que precisam ser atualizados na própria experiência e reconstrução da experiência democrática, com todos seus vícios e imperfeições. Em suma, pensar a educação para a democracia é pensar a educação na democracia.

E isso, sem que nenhuma metafísica ou metahistória possa predizer ou determinar o resultado necessário do processo. Sem que a solução aos problemas da democracia possa, de qualquer forma, ser colocada (ou imposta) a partir de fora, como também sugerido, aliás, cinicamente, pela Ditadura Militar ${ }^{37}$. A democracia, como caminho emancipatório,

34 DEWEY, Reconstruction in philosophy, 2004, p. 43; DEWEY, John. Experiência e educação. Trad. Renata Gaspar. Petrópolis/RJ: Vozes, 2010, p. 70.

${ }^{35}$ BITTAR, Justiça e emancipação, 2011, p. 655.

${ }^{36}$ DEWEY, John, Freedom and culture. Nova York: Prometheus Books, 1989, p. 88 e 97.

${ }^{37}$ WEFFORT, Por que democracia?, 1984, p. 32 e 40. 
depende, fundamentalmente, do conjunto de atores interessados que compõem o grupo social $^{38}$.

3. Daí o cuidado com o diagnóstico, na continuidade histórica brasileira, da permanência de vícios anteriores à ordem constitucional de 1988, mas que a ela se acomodam, limitando o alcance das transformações no sentido enriquecido que nela também tem lugar. Eis um legado que dá a medida do problema, complexo e ingente, da consolidação da democracia no país.

Tem de ser reconhecido, é verdade, que o Brasil vivenciou progressos significativos nos últimos vinte e seis anos de democracia. Disputa com o Reino Unido a posição de sexta maior economia do mundo ${ }^{39}$. Experimentou sensíveis avanços no campo dos direitos fundamentais ${ }^{40}$, elevados, a partir de 1996, pelos Planos Nacionais de Direitos Humanos, ao status de política pública ${ }^{41}$. Atualiza um inegável nível de institucionalização dos procedimentos político-eleitorais, superando, até agora, a tradição brasileira de usurpação golpista do poder ${ }^{42}$. Fez do diálogo e da participação método de governo, nos termos da Política Nacional de Participação Social.

Mas o país convive, ainda, com graves e históricos problemas sociais. Traz os infortúnios da aguda exclusão e desigualdade social; da pobreza extrema; dos altos índices de violência, revelados, por exemplo, na taxa nacional de homicídios, comparável à de uma guerra civil, de 29 por 100 mil habilitantes; da falta de moradia digna; da oferta inadequada de serviços públicos como saúde, saneamento básico e educação ${ }^{43}$. Moldam o

${ }^{38}$ HABERMAS, Direito e democracia, Vol. 01, 2012, p. 157, 163 e 164; DEMO, Pedro. Cidadania menor. Algumas indicações quantitativas de nossa pobreza política. Petrópolis: Vozes, 1992, p. 17 e 19.

39 CENTRE FOR ECONOMICS AND BUSINESS RESEARCH (CEBR). Cebr's World Economic League Table. Londres, 26/12/2013, p. 14. Disponível em: http://www.cebr.com/reports/cebr-world-economicleague-table/. Acesso em 20/10/2014.

${ }^{40}$ NÚCLEO DE ESTUDOS DA VIOLÊNCIA (NEV/USP). $5^{\circ}$ Relatório nacional sobre os direitos humanos no Brasil (2001-2010). São Paulo: Universidade de São Paulo/Núcleo de Estudos da Violência, 2012, p. 10.

${ }^{41}$ PIOVESAN, Temas de direitos humanos, 2003, p. 346.

42 WEFFORT, Por que democracia?, 1984, p. 40.

${ }^{43}$ CARVAlHO, José Murilo. Cidadania no Brasil: o longo caminho. 13aㅗ Ed. Rio de Janeiro: Civilização brasileira, 2010, p. 08; INSTITUTO BRASILEIRO DE GEOGRAFIA E ESTATÍSTICA - IBGE. Pesquisa Nacional de Saneamento Básico - PNSB 2008. Rio de Janeiro, 2010, p. 40 e 41. Disponível em: http://www.ibge.gov.br/home/estatistica/populacao/condicaodevida/pnsb2008/PNSB 2008.pdf. Acesso em 20/10/2012; NÚCLEO DE ESTUDOS DA VIOLÊNCIA (NEV/USP). 4 $4^{\circ}$ Relatório nacional sobre os direitos humanos no Brasil. São Paulo: Universidade de São Paulo/Núcleo de Estudos da Violência, 2010, p. 09 e 16. Disponível em: http://www.nevusp.org/downloads/down248.pdf. Acesso em 31/01/2014; LIMA NETO, Vicente Correia e outros. Nota Técnica $n^{-}$05. Estimativas do déficit habitacional brasileiro (PNAD 2007-2012). Brasília: IPEA, novembro/2013, p. 02 a 04. Disponível em: 
cenário de desarticulação social, de degeneração dos laços de solidariedade, de abertura à "linguagem" da violência ${ }^{44}$, no "estado de guerra latente", de que fala Darcy Ribeiro ${ }^{45}$.

$\mathrm{O}$ retrato da sociedade brasileira não reflete, suficientemente, as exigentes condições para a vivência comunicativa da democracia que, com Dewey e Habermas, não prescinde de sujeitos dispostos a fazer uso de sua liberdade comunicativa no enfrentamento racional e cooperativo dos problemas comuns. E isso, num espaço público que se aproxime, ao máximo, de uma situação dialógica de simetria, livre de coações, de ameaças, do engodo, do uso perlocucionário ou impositivo da linguagem ${ }^{46}$.

Ocorreram, certamente, "momentos de fusão" "47, na história recente do país, fazendo transparecer um poder comunicativo igualmente latente na sociedade $\operatorname{civil}^{48}$ : os movimentos das Diretas Já, ainda antes da redemocratização, dos Caras Pintadas e, recentemente, os "protestos de junho", em 2013. Ainda que se aponte seu caráter "espasmódico"49, isso não pode ser olvidado.

Todavia, no final das contas, a coordenação social tem se dado mais a partir da ambiência do não diálogo, na unilateralidade e verticalidade das relações com o Estado, na interação estratégica orientada ao êxito, valendo-se parasitariamente da linguagem ou apelando, sem dissimulações, para a violência escancarada; menos por meio da práxis argumentativa, voltada ao entendimento, na esfera pública.

Sobressaiu, sempre, o peso do aparelho governamental na moldagem da nação ${ }^{50}$, ocupando o lugar tradicional, na política nacional, de polo condutor da sociedade ${ }^{51}$. Não se

http://www.ipea.gov.br/portal/images/stories/PDFs/nota tecnica/131125 notatecnicadirur05.pdf. Acesso em 21/05/2014; WAISELFISZ, Julio Jacobo. Mapa da violência 2014. Os jovens do Brasil. Versão Preliminar. Rio de Janeiro: FLACSO/Brasil, $2014 . \quad$ Disponível http://www.mapadaviolencia.org.br/pdf2014/Mapa2014_JovensBrasil_Preliminar.pdf. $\quad$ Acesso em 20/10/2014.

${ }^{44}$ BITTAR, Eduardo C. B. O direito na pós-modernidade, 2009, p. 251 e 264.

${ }^{45}$ RIBEIRO, Darcy. O povo brasileiro. São Paulo: Cia das Letras, 2006, p. 152 e 153.

${ }^{46}$ DEWEY, The public and its problems, 1991, p. 184; HABERMAS, Direito e democracia, Vol. 02, 2011, p. 09; FREITAG, Bárbara. A questão da moralidade: da razão prática de Kant à ética discursiva de Habermas. Tempo social. Revista de Sociologia da USP. Volume 01, nº 02, São Paulo, 2 semestre de 1989, p. 37; HABERMAS, Jürgen. Teoria do agir comunicativo. Racionalidade da ação e racionalização social. Tomo 01. Trad. Paulo Astor Soethe. Revisão Técnica Flávio Beno Siebeneichler. São Paulo: Editora WMF Martins Fontes, 2012, p. 60 e 61.

${ }^{47}$ SOUSA JUNIOR, José Geraldo. Sociologia jurídica: condições sociais e possibilidades teóricas Porto Alegre: Sergio Antonio Fabris Editor, 2002, p. 64.

${ }^{48}$ HABERMAS, Direito e democracia, Vol. 01, 2012, p. 185 a 187.

${ }^{49}$ DEMO, Cidadania menor, 1992, p. 102.

${ }^{50}$ RICUPERO, Bernardo. Sete lições sobre as interpretações do Brasil. 2ª ed. São Paulo: Alameda, 2008, p. 168.

${ }^{51}$ FAORO, Os donos do poder, 1995, p. 740. 
destaca como instrumento do público para a mediação, a organização e a proteção de suas pretensões e de seus interesses compartilhados ${ }^{52}$. O sistema político, ainda que concebível como, apenas, uma parte da dimensão do público e do político ${ }^{53}$, segue preeminente, personificado, no "hiperpresidencialismo" brasileiro, principalmente, na figura chefe do Poder Executivo federal ${ }^{54}$.

A colagem patrimonialista ao poder, sob a "ética governista" imediatista - ocupada com a (re)eleição -, e seu exercício paternalista, clientelista, com traços populistas mais ou menos acentuados, revivem, na tradição política do país, a antipatia à ampliação e ao fortalecimento dos procedimentos democráticos de participação popular. Chama a atenção, no Brasil, "a mesmice histórica das elites (...) Sua capacidade de regeneração é proverbial (...) Há famílias reais na política, governadores quase vitalícios, congressistas cativos”55. Renovando lideranças políticas identificadas, com frequência, como salvadores da pátria $^{56}$, apoderam-se, por fim, “dos processos espontâneos de formação da opinião e da vontade, privando-os de seu conteúdo"

O fluxo comunicacional segue invertido, correndo na direção centrífuga, do centro político para a sociedade civil. Desse modo, esvaziada a esfera pública democrática, "amplia-se o espaço para uma mobilização planejada da lealdade das massas e se facilita, de outro lado, a separação entre as decisões políticas e os contextos concretos de vida que formam a identidade e fornecem elementos para a legitimação" ${ }^{n 8}$.

Mas não é só isso. A concepção habermasiana de colonização sistêmica do mundo da vida demanda a referência fundamental, também, diante da formatação econômica adotada pelo Estado brasileiro, à contaminação da práxis linguística cotidiana pelos imperativos do mercado capitalista. Correm paralelamente às coações historicamente

\footnotetext{
${ }^{52}$ DEWEY, The public and its problems, 1991, p. 33.

${ }^{53}$ HABERMAS, Direito e democracia, Vol. 02, 2011, p. 220; AVRITZER, Leonardo. A moralidade da democracia: ensaios em teoria habermasiana e teoria democrática. São Paulo: Perspectiva; Belo Horizonte: Editora UFMG, 1996, p. 150.

${ }^{54}$ RANIERI, $O$ estado democrático de direito e o sentido da exigência de preparo para o exercício da cidadania, pela via da educação, 2009, p. 384 e 385.

${ }^{55}$ DEMO, Cidadania menor, 1992, p. 103.

${ }^{56}$ CARVALHO, Cidadania no Brasil, 2010, p. 221.

${ }^{57}$ HABERMAS, Jürgen. Teoria do agir comunicativo. Sobre a crítica da razão funcionalista. Tomo 02. Trad. Flávio Beno Siebeneichler. São Paulo: WMF Martins Fontes, 2012, p. 588.

${ }^{58}$ HABERMAS, Teoria do agir comunicativo, Tomo 02, 2012, p. 588.
} 
levadas a cabo pelo sistema político e se perfazem no sentido da monetarização, do consumismo, do individualismo, da competitividade, da lucratividade ${ }^{59}$.

Por todos os lados, enfim, solapa-se o agir comunicativo, orientado ao entendimento, atropelando seu potencial racional. Prejudica-se o alargamento e a reprodução crítica dos elementos estruturais do mundo da vida racionalizado (cultura, sociedade e personalidade), os quais somente se perfazem por meio de processos linguísticos de socialização e de renovação das tradições culturais e dos padrões de interação e integração social ${ }^{60}$. O que prevalece é o momento instrumental da racionalidade, que conhece e manipula a natureza e a sociedade objetivada ${ }^{61}$.

Nesse esvaziamento da esfera pública, confusão de espaços do mercado, da política e do mundo da vida, e deformação da razão, Habermas vai destacar os prejuízos à qualidade discursiva da comunicação pública. É objeto de distorções, manipulações e influxos do poder ilegítimo e do dinheiro, cuja denúncia e neutralização demandariam, justamente, o discurso evitado. Submetida "ao poder e à dominação dos meios de comunicação de massa", o espaço público é despolitizado ${ }^{62}$, figurando o cidadão muito mais como consumidor submetido à estrutura econômica do mercado, à "estética das vitrines e dos balcões de ofertas de novidades de consumo"63, do que ator social comunicativo, determinante nas relações com o sistema político. Vê "notícias sobre acontecimentos políticos no formato de entretenimento. A informação política se torna mercadoria, até a propaganda eleitoral não se distingue da comercial" ${ }^{\text {64 }}$.

Apoiado o convencimento no trabalho de publicidade de partidos, de organizações políticas e de corporações empresariais ${ }^{65}$ - na fala de Freud, "um convencimento que não se baseia na percepção e no trabalho do pensamento"66 - via de regra:

(...) o que decide o destino de uma pessoa que concorre na eleição não é sua excelência tampouco seus defeitos políticos. A corrente segue a favor ou contra o partido no poder e o candidato afunda ou nada conforme a

\footnotetext{
${ }^{59}$ HABERMAS, Teoria do agir comunicativo, Tomo 02, 2012, p. 587.

${ }^{60}$ HABERMAS, Teoria do agir comunicativo, Tomo 02, 2012, p. 252, 253 e 265.

61 HABERMAS, Jürgen. $O$ discurso filosófico da modernidade. Trad. Luiz Sérgio Repa e Rodnei Nascimento. São Paulo: Martins Fontes, 2002, p. 438.

${ }^{62}$ HABERMAS, Direito e democracia, Vol. 02, 2011, p. 111.

${ }^{63}$ BITTAR, O direito na pós-modernidade, 2009, p. 381.

${ }^{64}$ PINZANI, Alessandro. Habermas. Porto Alegre: Artmed, 2009, p. 42.

${ }^{65}$ HABERMAS, Direito e democracia, Vol. 02, 2011, p. 100.

${ }^{66}$ FREUD, Sigmund. Psicologia das massas e análise do eu. In Obras completas. Volume 15. Psicologia das massas e análise do eu e outros textos (1920-1923). Trad. Paulo César de Souza. São Paulo: Cia das Letras, 2011 , p. 43 e 92.
} 
correnteza. Às vezes, há um sentimento consensual, uma tendência definida em favor da "legislação progressiva" ou um desejo de "retorno à normalidade" (...) Outras vezes, o hábito, os fundos partidários, a habilidade dos gerenciadores da máquina, o retrato do candidato com seu maxilar firme, sua amável esposa e filhos, e uma multidão de outras irrelevâncias determinam a questão ${ }^{67}$.

É bastante adequado ao cenário brasileiro, nesse sentido, o diagnóstico deweyano de desarticulação ou eclipse do público. Não se reconhece como tal de modo a se organizar comunicativamente, promovendo cooperativamente interpretações públicas às experiências sociais e, assim, direcionar a formação institucionalizada da vontade, no âmbito do sistema político comprometido com o momento comunicativo que lhe precede e do qual emerge ${ }^{68}$.

Diante do déficit de engajamento discursivo da sociedade civil, o debate público, as questões políticas se reduzem, como já indicava Dewey, à escolha entre dois (ou alguns) candidatos ao cargo eletivo ${ }^{69}$. A eleição, no final das contas "mesmo formalmente livre, lhe reserva (ao povo) a escolha entre opções que ele não formulou"70. E isso, no mutualismo nada republicano da "esquizofrenia" "71 que se cola à política do país: cético e desconfiado em relação à participação democrática e as reformas sociais tão necessárias, o cidadão atomizado - Demo dirá menor - deposita as últimas esperanças nas respostas unilaterais, simplistas e imediatistas do líder taumaturgo. Vota em troca de obtenção de proteção (oposta à pretensão emancipatória), vantagens, favores e privilégios ${ }^{72}$, na "dualidade (que) oscila entre a decepção e o engodo",73.

Enfim, a participação política no Brasil, no mais das vezes, reduz-se ao exercício isolado e periódico do voto. Decaída no eleitorismo, não rompe, como projetado pela Constituição de 1988, o passado constitucional da democracia formal-representativa. Afinal, o poder que emana do povo permanece a ele ligado, muito mais, na retórica política cínica, autolegitimadora. E dele pode se descolar, em seu exercício pelos agentes governamentais $^{74}$, no âmbito de uma formalidade democrática que se não se atualiza na

\footnotetext{
${ }^{67}$ DEWEY, The public and its problems, 1991, p. 122.

${ }^{68}$ DEWEY, The public and its problems, 1991, p. 33 e 126; HABERMAS, Direito e democracia, Vol. 02, 2011, p. 100; HABERMAS, Teoria do agir comunicativo, Tomo 01, 2012, p. 138.

${ }^{69}$ DEWEY, The public and its problems, 1991, p. 119 e 120.

${ }^{70}$ FAORO, Os donos do poder, 1995, p. 748.

${ }^{71}$ CARVALHO, Cidadania no Brasil, 2010, p. 224.

${ }^{72}$ DEWEY, The public and its problems, 1991, p. 118; DEMO, Cidadania menor, 1992, p. 103; FAORO, Os donos do poder, 1995, p. 740; CARVALHO, Cidadania no Brasil, 2010, p. 07.

${ }^{73}$ FAORO, Os donos do poder, 1995, p. 744.

${ }^{74}$ WEFFORT, Por que democracia?, 1984, p. 53; MOISÉS, José Álvaro. Os brasileiros e a democracia. Bases sócio-políticas da legitimidade democrática. São Paulo: Ática, 1995, p. 35.
} 
horizontalidade da linguagem, mas coabita com padrões de conduta unilateralizados e verticalizados ${ }^{75}$.

A aprendizagem da democracia, no Brasil, só tem lugar no continuum de uma (in)experiência, até agora, bastante contida na ambiência precária que combina o desrespeito sistemático aos direitos fundamentais, sem os quais é impensável a constituição digna e racional do sujeito, capaz de participar ativamente da vida social; a exclusão social, sinônimo de exclusão comunicativa, que nega a grande contingente da população, formalmente cidadão, a entrada na "comunidade de participação que determina o fim das deliberações comuns"76; a desintegração, pela violência, dos laços de cooperação; a coordenação social viciada, a partir de cálculos egocêntricos de êxito individual, reticente ao diálogo voltado ao entendimento; “o patronato político sobre a nação, impenetrável ao poder majoritário", ainda não desfeito pela pressão democratizante ${ }^{77}$.

Faz presente o dilema legitimatório que, como afirma Habermas, soma a "fraqueza da sociedade civil e da esfera pública", em termos racionais-discursivos, à primazia do poder ilegítimo, desvinculado do fluxo comunicacional que daqueles haveria de $\operatorname{provir}^{78}$. $\mathrm{Na}$ hermenêutica constitucional, a "comunidade de intérpretes", distante da situação dialógica ideal, conforma-se com pouco, quando o assunto é democracia. Refreia a ampliação, a reconstrução, o enriquecimento comunicativo, numa espiral positiva contínua, do "sistema de direitos carentes de interpretação e de configuração", a partir de seu interior, pela sociedade, concebida, de fato, como conjunto de parceiros do direito ${ }^{79}$.

4. De qualquer forma, se a inexperiência que conforma e empobrece o conteúdo da democracia, no Brasil, é fruto de um continuum histórico-cultural, a experiência enriquecida, na moldura jurídico-constitucional de 1988, também o é. Ao menos, pode ser.

Sob a perspectiva hermenêutica apoiada na filosofia social de Dewey e Habermas, pode, então, apropriar-se de um sentido que não é, absolutamente, estranho à modernidade assimilada na Constituição Federal.

75 KELSEN, Hans. A democracia. Trad. Ivone C. Benedetti e outros. São Paulo: Martins Fontes, 2000, p. 189.

${ }^{76}$ BITTAR, Justiça e emancipação, 2011, p. 651 e 685.

${ }^{77}$ FAORO, Os donos do poder, 1995, p. 747 e 748.

${ }^{78}$ HABERMAS. Direito e democracia, Vol. 02, 2011, p. 121 e 122.

${ }^{79}$ HABERMAS, Direito e democracia, Vol. 01, 2012, p. 199. 
Afinal, os autores propugnam a reflexão crítica que, operando no interior da tradição moderna ${ }^{80}$, não pretende, absolutamente, dela se desvencilhar, negando-a a partir de fora. Isso não afigura possível. Fugindo ao que Dewey intitulou a filosofia de extremos opostos, que "pensa e age em termos de “ismos"”,81, valem-se, no diagnóstico dos descaminhos da modernidade e na retomada do projeto emancipatório, dos recursos, instrumentos, experiências e aprendizagens por ela proporcionados. Vendo-a, enfim, na sua dialética de avanços e retrocessos ${ }^{82}$, não se posicionam como antimodernidade $^{83}$. Não caem em antimodernismos.

Aprendem com os desacertos, cientificistas, tecnicistas, especialistas, presos à filosofia da consciência. A realização deformada da razão cindida, reduzida ao momento cognitivo-instrumental $^{84}$, se possibilitou inegáveis progressos materiais, não capacitou a humanidade ao enfrentamento de questões sociais e morais que a afligem. Foram desastrosos os resultados de seu predomínio no campo das interações humanas ${ }^{85}$, decaídas em relação solipsista "ego/isso", tendo por "isso" "indiferentemente, 'ele' (outro sujeito humano qualquer) ou 'aquilo' (outra matéria não humana qualquer)". Reificou o objeto do conhecimento, como "algo servível (e utilizável) ou a algo inservível (e descartável)"86.

Diante da dialética do esclarecimento, em que o irrefreável progresso foi de par com o equivalente regresso irrefreável ${ }^{87}$ - desligada a instrumentalidade das tecnologias de sentidos atribuídos socialmente -, fica claro, para os filósofos, que não é mais admissível a crença otimista e ingênua do iluminismo de que o progresso técnico-científico caminharia junto com o desenvolvimento moral ${ }^{88}$ : "a fé de que a ciência e a liberdade humana avançariam de mãos dadas, prenunciando a era da infinita perfectibilidade humana" 89 .

Não por isso abandonam a razão, a ciência, a modernidade. Nelas identificam, criticamente, elementos que confirmam os potenciais emancipatórios e que equipam de

${ }^{80}$ BITTAR, Justiça e emancipação, 2011, p. 110.

${ }^{81}$ DEWEY, Experiência e educação, 2010, p. 14 e 19.

${ }^{82}$ BITTAR, Justiça e emancipação, 2011, p. 348.

${ }^{83}$ HABERMAS, Modernidade - um projeto inacabado, 1992, p. 99.

${ }^{84}$ HABERMAS, $O$ discurso filosófico da modernidade, 2002, p. 439.

${ }^{85}$ BITTAR, Justiça e emancipação, 2011, p. 348 e 350.

${ }^{86}$ FERRAZ JUNIOR. Tércio Sampaio. Responsabilidade sem culpa, culpa sem responsabilidade na sociedade tecnológica. In FABIANI, Emerson Ribeiro (org.). Impasses e aporias do direito contemporâneo. Estudos em homenagem a José Eduardo Faria. São Paulo: Saraiva, 2011, p. 140.

${ }^{87}$ ADORNO, Theodor W. \& HORKHEIMER, Max. Dialética do Esclarecimento. Fragmentos Filosóficos. Trad. Guido Antonio de Almeida. Rio de Janeiro: Zahar, 1985, p. 41.

${ }^{88}$ HABERMAS, Jürgen, Teoría y praxis: estudios de filosofia social. Trad. Salvador Más Torres e Carlos Moya Espí. $2^{\mathrm{a}}$ ed. Madrid: Tecnos, 1990, p. 314 e 319.

${ }^{89}$ DEWEY, Freedom and culture, 1988, p. 102 e 106. 
instrumentos, tipicamente modernos, para enfrentar os descaminhos diagnosticados ${ }^{90}$. Primeiro, a filosofia reconstruída pragmatista deweyana, assimilando a atitude investigativa, experimental, metódica e falibilista própria à ciência moderna, e a orientando, comunicativamente, ao esclarecimento e à compreensão do significado das experiências humanas cotidianas e à solução inteligente dos conflitos sociais e morais. Depois, a teoria social crítica habermasiana, de modo não distante, destacando a comunicação orientada ao entendimento como o lugar intersubjetivo da racionalidade: a razão comunicativa, referida à suscetibilidade à crítica e à capacidade fundamentação de pretensões de validade e ampliada, de modo a agregar o momento instrumental, sem a ele se reduzir. É a partir do potencial racional embutido na prática linguística cotidiana, que Habermas entrevê o percurso emancipatório de reversão da colonização sistêmica do mundo da vida e, com isso, da contaminação dos processos de entendimento que nele se desenrolam $^{91}$. Por fim, o pensamento de ambos, atribuindo valor essencial à linguagem como ambiência fundamental da aprendizagem $^{92}$. Atualizando seus sentidos cognitivo e prático $^{93}$, ou instrumental e consumatório $^{94}$, ela sedia a constituição social da individualidade, a construção cooperativa do conhecimento e, na redefinição dialógica do imperativo categórico ${ }^{95}$, a definição da moralidade.

Tudo isso reflete na proposição de modelos de democracia e de educação, apreendidos, na revisita ao projeto moderno, como experiências indissociáveis na direção iluminista da emancipação humana, por meio da razão (agora, comunicativa).

Nesse sentido, conceber a educação para a democracia, à luz das filosofias de Dewey e de Habermas não foge do horizonte de experimentação jurídica, aberto pelo texto constitucional de 1988, de um Estado Democrático de Direito, fortemente apoiado nos direitos humanos, dentre os quais a educação. As propostas deweyanas, na tradição no pragmatismo norte-americano da primeira metade do século passado, e a teoria social crítica habermasiana, representando a "segunda geração" da Escola de Frankfurt, revelam-

\footnotetext{
${ }^{90}$ BITTAR, Justiça e emancipação, 2011, p. 108.

${ }^{91}$ HABERMAS, Teoria do agir comunicativo, Tomo 01, 2012, p. 45, 138 e 674; HABERMAS, Teoria do agir comunicativo, Tomo 02, 2012, p. 265, 595 e 601.

92 HABERMAS, Teoria do agir comunicativo, Tomo 01, 2012, p. 49 e 57; DEWEY, Experiência e natureza, 1980 , p. 29.

${ }_{93}^{93}$ HABERMAS, Direito e democracia, Vol. 01, 2012, p. 190 e 191.

${ }^{94}$ DEWEY, Experiência e natureza, 1980, p. 39.

95 BITTAR, Justiça e emancipação, 2011, p. 235.
} 
se, certamente, muito mais alinhadas com o projeto constitucional brasileiro do que as heranças autoritárias, verticalizadas, não-dialógicas que insistem em perverter seu sentido.

Fazem do texto constitucional, de acordo com seu conteúdo, um ponto de partida, um projeto de sentido ${ }^{96}$, marcadamente histórico - que não ignora o passado nem os desafios do presente -, do esforço de uma experiência democrática a ser processualmente construída, vivida e aprendida, para além do sentido formal de seus mecanismos e procedimentos institucionalizados.

5. A democracia se configura, no pensamento de Dewey e no de Habermas, como experiência social - e também racional e moral cognitivista - de autodeterminação, autolegislação, autonomia, em que pode ser atualizado o projeto moderno emancipatório ${ }^{97}$.

Efetiva-se como um processo bastante ampliado de encaminhamento, enfrentamento e solução racional, cooperativa e conjunta de problemas comuns. Nessa extensão, um processo de formação discursiva da opinião e da vontade; de deliberação e tomada de decisões coletivas ${ }^{98}$.

5.1. A experiência democrática assume, como paradigma, o discurso. Orienta-se pela institucionalização de ambientes, mecanismos e procedimentos coadunados com a práxis argumentativa orientada ao entendimento. Uma práxis que permite às ideias por meio delas comunicadas o cumprimento do "pressuposto central da racionalidade: elas podem ser fundamentadas e criticadas" "99 . É sob a ideia de discurso que se consolida, na democracia, a noção de autolegislação, de autonomia.

Assim, em termos metodológicos pragmatistas, trazidos para a vida social e em vista de sua coordenação, a referência passa a ser a busca cooperativa da verdade (e da correção, da justiça social), no enfrentamento de conflitos e questões com que a sociedade

${ }^{96}$ BITTAR, Linguagem jurídica, 2010, p. 136.

97 DEWEY, The public and its problems, 1991, p. 17, 34 e35; HABERMAS, Jürgen. A inclusão do outro. Estudos de teoria política. Trad. George Sperber, Paulo Astor Soethe e Milton Camargo Mota. $3^{\underline{a}}$ ed. São Paulo: Loyola, 2007, p. 278, 284.

${ }^{98}$ DEWEY, The public and its problems, 1991, p. 16, 17, 27, 28, 33, 35, 143, 148 e 149; HABERMAS, A inclusão do outro, 2007, p. 291 e 292; HABERMAS, Direito e democracia, Vol. 02, 2011, p. 19, 21, 22 e 45; HONNETH, Axel. Democracy as reflexive cooperation: John Dewey and the theory of democracy today. Political Theory, vol. 26, n⿳0 06, Dez/1998, p. 774.

${ }^{99}$ HABERMAS, Teoria do agir comunicativo, Tomo 01, 2012, p. 45. 
se depara no curso das interações humanas. Promove-se a aliança potencial entre o método científico e o democrático, "nas técnicas de legislação e administração"100.

Invoca-se, como modelo de interação social - a colar em todos as instituições e momentos da vida democrática -, a estrutura comunicativa que, renunciando à violência e ao uso parasitário da linguagem (perlocucionário, unilateralizado ou impositivo) dê guarida e vasão às boas razões, ao melhor argumento: a única coação admitida ${ }^{101}$.

Dessa forma, o discurso pode institucionalizar seu enorme potencial cognitivo e prático/consumatório. A linguagem a partir da qual se forma a individualidade (o eu), sem perder a referência ao grupo social e suas formas de vida (o nós), realiza-se, ao mesmo tempo, como o instrumento por meio do qual o universo linguístico e cultural do grupo se aperfeiçoa. Na contraposição racional de crítica e fundamentação de pretensões de validade que se tornaram problemáticas, os saberes podem ser permanentemente revisitados e reconsiderados ante as exigências da conversação. Os horizontes experienciais egocêntricos e contextualizados podem se ampliar e se somar cada vez mais, na contradição e complementaridade de abordagens da realidade e de sentidos atribuídos. As argumentações, em suma, correlatas à aprendizagem, trazem consigo a permanente correção, extensão, aprofundamento e enriquecimento do conhecimento ${ }^{102}$.

A concepção moral cognitivista dos dois filósofos permite trazer, ainda, para a esfera da razão, construída no diálogo, o debate e a solução de questões práticas, atinentes ao mundo social. $\mathrm{O}$ discurso confere à democracia recursos para dirimir consensualmente os conflitos de ação, reconhecida a possibilidade de julgamento inteligente do valor das condutas humanas e de distinção, nessa matéria, entre juízos corretos e errados $^{103}$.

${ }^{100}$ DEWEY, Freedom and culture, 1989, p. 81; BERNSTEIN, Richard J. The resurgence of pragmatism. Social research, vol. 59, $\mathrm{n}^{\mathrm{o}}$ 4, 1992, p. 814 e 815; JOAS, Hans. Pragmatism and social theory. Chicago: University of Chicago Press, 1993, p. 19; HONNETH. Democracy as reflexive cooperation, 1998, p. 772 e 773.

${ }^{101}$ HABERMAS, Direito e democracia, Vol. 01, 2012, p. 283 e 284; BITTAR, Justiça e emancipação, 2011, p. 593.

${ }_{102}$ DEWEY, Experiência e natureza, 1980, p. 29 e 39; MEAD, Mind, self and society, 1992, p. 201; HABERMAS, Direito e democracia, Vol. 01, 2012, p. 190 e 191; HABERMAS, Jürgen. A ética da discussão e a questão da verdade. Organização e introdução de Patrick Savidan. Trad. Marcelo Brandão Cipolla. $2^{\underline{a}}$ ed. São Paulo: Martins Fontes, 2007, p. 10; HABERMAS, Teoria do agir comunicativo, Tomo 01, 2012, p. 49 e 57; HABERMAS, Jürgen. Verdade e justificação. Ensaios filosóficos. Trad. Milton Camargo Mota. 2a ed. São Paulo: Loyola, 2009, p. 71 e 95.

${ }^{103}$ DEWEY, John. The study of ethics. A syllabus. Ann Arbor: The Inland Press, 1879, p. 01; DEWEY, John. Ethics. The Later Works 1925-1953. Volume 07 (1932). Edited by Jo Ann Boydston. Southern Illinois University, 2008, p. 09; HABERMAS, Jürgen. Consciência Moral e Agir Comunicativo. Trad. Guido A. de Almeida. Rio de Janeiro: Tempo Brasileiro, 2003, p. 87 e 147. 
Tudo isso no âmbito de uma interação em que os comunicantes optam pela solução pautada no entendimento, na razão imanente à linguagem, abrindo-se ao outro como parceiro de comunicação, que compartilha o sentido do que fora dito ${ }^{104}$. Faz-se, assim, da instrumentalidade incomparável, que caracteriza o discurso, concomitantemente, um incomparável fim em si. A linguagem, destaca Dewey, não encontra rival, em seu sentido recompensador e satisfatório, de um repartir, de uma comunhão de significados, ampliados, aprofundados e consolidados na medida da participação. No medium linguístico, a personalidade - que não se efetiva monologicamente, em isolamento - pode se realizar na perspectiva existencial da participação e contribuição particular, conscientemente afirmada, na experiência social comunicativa ${ }^{105}$.

5.2. Para tanto, a democracia não abre mão, absolutamente, dos procedimentos e dos mecanismos participativos, diretos e indiretos, previstos no texto constitucional, na extensão em que positivam os pressupostos e exigências do discurso. Lembre-se: o princípio da democracia, para Habermas, é a forma assumida pelo princípio do discurso, pela via da institucionalização jurídica, de modo a "amarrar um procedimento de normatização legítima do direito"106.

Compõe-se, nesse sentido, como um processo comunicativo que passa, sem dúvida, pela democracia política, amparada em direitos fundamentais, em todas as suas dimensões, a permitir o exercício da soberania popular. Envolve, necessariamente, as instituições e regras procedimentais, próprias ao jogo democrático, como o sufrágio universal, a regra da maioria, as eleições periódicas para a escolha dos ocupantes de cargos políticos e assim por diante. Não dispensa, em suma, o mínimo procedimentalista ${ }^{107}$.

Todavia, a democracia "não pode, agora, depender ou ser expressa, apenas, em instituições políticas"108. Estas não esgotam seu conteúdo normativo. O problema da democracia não se restringe à questão do funcionamento minimamente adequado de

${ }^{104}$ MEAD, Mind, self and society, 1992, p. 327; HABERMAS, Direito e democracia, Vol. 01, 2012, p. 191; OLIVEIRA, Manfredo Araújo de. Escola e sociedade: questão de fundo de uma educação libertadora. Revista de Educação AEC. Brasília, ano 18, nํ71, jan/mar. 1989, p. 23.

${ }^{105}$ DEWEY, Experiência e natureza, 1980, p. 30, 36, 39, 40 e 51; DEWEY, The public and its problems, 1991, p. 150 a 152.

${ }^{106}$ HABERMAS, Direito e democracia, Vol. 01, 2012, p. 145 e 158.

107 DEWEY, The public and its problems, 1991, p. 144 e 145; HABERMAS, Direito e democracia, Vol. 02, 2011, p. 26 e 27; BOBBIO, Norberto. O futuro da democracia. Uma defesa das regras do jogo. Trad. Marco A. Nogueira. 5- Ed. Rio de Janeiro: Paz e Terra, 1992, p. 18, 19, 20 e 37.

${ }^{108}$ DEWEY, Freedom and culture, 1988, p. 97. 
mecanismos institucionais, estendidos à existência de partidos políticos, à liberdade de expressão em seu sentido mais lato, à realização das eleições e à atuação rotineira dos órgãos governamentais. Liga-se, também e fundamentalmente, às práticas cotidianas do sistema político; dos movimentos e agrupamentos sociais; e às relações entre ambos, no medium jurídico-constitucional ${ }^{109}$.

Torna-se elementar à experiência democrática os hábitos comunicativos de pensar, agir e conviver dos atores sociais, possibilitados, promovidos e atualizados com o amparo das instituições político-democráticos ${ }^{110}$. Habermas atribui a Dewey o mérito de ter sublinhado essa ideia. De fato, referindo-se ao processo eleitoral - a que tem se reduzido, em grande medida, a democracia brasileira -, o filósofo pragmatista ressalta que seu dado mais significativo "é que a contagem de cabeças força o recurso prévio aos métodos de discussão, consulta e persuasão"111.

Nesse sentido, o ato de votar nas eleições para os cargos políticos do Poder Executivo e Legislativo dos três níveis da federação significa um momento, sem dúvida fundamental, dentre tantos outros que compõem a experiência dialógica e participativa da democracia. Não pode ser visto como o momento do exercício da cidadania: "democracia é muito mais do que a formalidade do voto" ${ }^{\prime 12}$.

É a experiência precedente, então, que sobressai e dá vigor ao exercício dos canais institucionais de participação direta e dos mecanismos de representação. A democracia não pode perder de vista a compatibilização "entre a operação de instituições políticas e os valores de uma esfera societária na qual predominem práticas democráticas"113. Todo o aparato político perde seu sentido sem a ambiência democrática de discussão de questões públicas, pela sociedade civil, irradiada aos mais diversos âmbitos da vida social, passando pelos movimentos sociais e populares, pelos agrupamentos culturais, políticos e econômicos, pelas associações de bairro, pelos meios acadêmicos, etc. Antecipando mecanismos previstos na Política Nacional de Participação Social, Maria Victoria

109 AVRITZER, A moralidade da democracia, 1996, p. 138; HABERMAS, Direito e democracia, Vol. 02, 2011, p. 90; SARAMAGO, José. As palavras de Saramago: catálogo de reflexões pessoais, literárias e políticas. Sel. e Org. Fernando Gómez Aguilera. Trad. Rosa Freire d'Aguiar e outros. São Paulo: Cia das Letras, 2010, p. 384.

${ }^{110}$ HABERMAS, Direito e democracia, Vol. 02, 2011, p. 27.

${ }^{111}$ DEWEY, The public and its problems, 1991, p. 207.

112 DALLARI, Dalmo de Abreu. Educação e preparação para a cidadania. In BENEVIDES, Maria Victoria de Mesquita; BERCOVICI, Gilberto; MELO, Claudinei de. Direitos humanos, democracia e república: homenagem a Fábio Konder Comparato. São Paulo: Quartier Latin, 2009, p. 345.

${ }^{113}$ AVRITZER, A moralidade da democracia, 1996,p. 149. 
Benevides cita, como exemplos de cidadania ativa, a participação dos usuários na gestão dos serviços públicos e dos alunos, pais e professores na gestão da instituição escolar; as experiências de orçamento participativo; a criação de ouvidorias populares em órgãos do Poder Público ${ }^{114}$.

Na prática semidireta da democracia, inscrita na Constituição de 1988, isso implica que "Em qualquer hipótese, conselhos populares, conselhos de empresa, etc. têm de conviver com partidos e parlamentos. A participação popular que se dá, de modo direto, nas ruas e nas praças tem de conviver com a participação em eleições para o parlamento e para os governos",115.

5.3. Sendo assim, valorizando a intersubjetividade mediada pela linguagem - que, afinal, distingue a vida em sociedade ${ }^{116}$ - a democracia envolve um fluxo comunicacional que se ancora no público de pessoas privadas, que compõe a sociedade civil e que atuam na esfera pública. Depende dessa base comunicativa, enraizada no horizonte experiencial de um mundo da vida racionalizado, no qual são continuamente retomadas experiências de identificação, debate e tratamento de problemas da sociedade como um todo; de articulação de demandas; de luta por reconhecimento e convencimento de pretensões; de construção de opiniões públicas e de soluções compartilhadas ${ }^{117}$.

Esse fluxo comunicacional desemboca, então, sistema político, composto pelos órgãos governamentais dos três poderes (Legislativo, Executivo e Judiciário). Nele, através de um filtro discursivo, os problemas tematizados, elaborados e interpretados publicamente encontram eco, recebendo tratamento e solução institucional, pela linguagem do direito ${ }^{118}$. A atuação do sistema político é definida, portanto, como um momento vinculado e instrumental da democracia ${ }^{119}$, necessariamente referido à experiência comunicativa anterior, protagonizada pela sociedade civil. Mantém, assim, o nexo com fontes do mundo

\footnotetext{
${ }^{114}$ BENEVIDES, A cidadania ativa, 2003, p. 18; BENEVIDES, Em defesa da república e da democracia, 2009 , p. 728.

${ }^{115}$ WEFFORT, Por que democracia?, 1984, p. 125

${ }^{116}$ MEAD, Mind, self and society, 1992, p. 235 e 237; HABERMAS, Teoria do agir comunicativo, 2012, p. 22.

${ }^{117}$ HABERMAS, Direito e democracia, Vol. 02, 2011, p. 22, 24, 41, 92 e 100.

${ }_{118}^{11}$ HABERMAS, Direito e democracia, Vol. 02, 2011, p. 45, 46, 91, 92, 120 e 121.

${ }^{119}$ DEWEY, The public and its problems, 1991, p. 69 e 146.
} 
da vida do qual não pode prescindir: a cultura política crítica, a socialização cooperativa e solidária, a personalidade racional e esclarecida ${ }^{120}$.

No oposto da configuração histórica da política brasileira, o aparelho governamental não conforma, não se impõe, não esvazia de conteúdo a esfera pública. Ele emerge e é direcionado pelo público formado pela sociedade civil. Corresponde a uma dimensão importante do espaço público político. Todavia, não ocupa o lugar do todo. Nem mesmo o papel central ${ }^{121}$ : "O governo não é o Estado, pois este inclui o público, assim como os governantes (...) que agem como representantes dos interesses públicos”. O sistema político existe para servir à comunidade da qual emerge. Seu propósito "não pode ser atingido a menos que a comunidade tome parte na seleção de seus governantes e na determinação de suas políticas" ${ }^{\prime 122}$.

Atua, então, na elaboração jurídica de decisões coletivas em relação a problemas que afetam a sociedade como um todo, mas que as demais esferas e padrões de interação não puderam solucionar. A política "mantém uma relação com os problemas da sociedade em seu conjunto, ou seja, ela continua num nível reflexivo uma integração social que outros sistemas de ação não conseguem mais desempenhar suficientemente"123.

Para tanto, apoiado discursivamente, o exercício do poder político deve se constituir a partir do poder comunicativamente gerado. Privilegiam-se, assim, contra a colonização do espaço público pelo sistema político, os processos de entendimento, que "constituem o centro do mundo da vida", como ambiência definidora da manutenção do sistema $^{124}$.

5.4. O caminho, dessa forma percorrido, possibilita a construção, no cenário pósmetafísico, da legitimidade a partir da legalidade democrática. A legitimidade se desliga da referência a um metadireito sem, com isso, perder-se num sistema positivista que se reproduz autorreferencialmente. Doravante, é vinculada à ideia de autolegislação, concreta e contextualmente experimentada, de acordo com a qual os sujeitos de direito, na condição

\footnotetext{
120 HABERMAS, Direito e democracia, Vol. 02, 2011, p. 23 e 25; HABERMAS, Teoria do agir comunicativo, Tomo 02, 2012, p. 260 e 577.

${ }^{121}$ DEWEY, The public and its problems, 1991, p. 146; AVRITZER, A moralidade da democracia, 1996, p. 150; HABERMAS, Direito e democracia, Vol. 02, 2011, p. 25 e 220.

${ }^{122}$ DEWEY, The public and its problems, 1991, p. 27, 28 e 146.

${ }^{123}$ HABERMAS, Direito e democracia, Vol. 02, 2011, p. 45, 46, 120 e 121.

${ }^{124}$ HABERMAS, Teoria do agir comunicativo, Tomo 02, 2012, p. 278, 334 e 588.
} 
de destinatários, ocupam os espaços públicos e se entendem, concomitantemente, como seus autores. Apoia-se, portanto, no engajamento e no arranjo racional-comunicativo, sob o princípio do discurso: "enquanto participantes de discursos racionais, os parceiros do direito devem examinar se uma norma controvertida encontra ou poderia encontrar o assentimento de todos os possíveis atingidos"125.

$\mathrm{O}$ direito permanece inegavelmente um instrumento da política, no âmbito do qual e por meio do qual são enfrentados institucionalmente conflitos de coordenação social. Todavia, segue, também, entrelaçado à moral, procedimentalizada e racionalizada no discurso. Consolidado na racionalidade comunicativa e no procedimento argumentativo, "O direito situa-se entre a política e a moral"126.

Para que não perverta o sentido democrático e para que se distinga, como conceito específico, da arbitrariedade, da impositividade, da "experiência pura e crua do poder""127, seja lá sob qual justificação, é indispensável que o direito traga consigo a resgatabilidade (e, nessa medida, a corrigibilidade) discursiva de sua pretensão de correção normativa ${ }^{128}$.

E assim, pela via do procedimento discursivo de autolegislação, a legitimidade da legalidade democrática realiza-se, de acordo com a tradição jurídica da modernidade, a partir do nexo entre soberania popular e direitos humanos ${ }^{129}$, dois conceitos, como já destacado, resguardados pelo sistema constitucional instituído em 1988.

O sistema jurídico assegura direitos fundamentais que permitem a participação em igualdade de condições nos processos, diretos e indiretos, de formação da opinião e da vontade. Nele amparado, os atores sociais atualizam-no, reconstroem-no, enriquecem-no, exercendo intersubjetivamente a soberania popular $^{130}$.

No âmbito de uma sociedade inexperiente em termos de democracia e respeito aos direitos humanos, como a brasileira, os atores sociais podem, então, atuando no medium jurídico-constitucional, experienciar progressivamente - não sem resistências, é claro - o fluxo comunicacional na direção centrípeta, em que o tratamento institucional das questões

\footnotetext{
${ }^{125}$ HABERMAS, Direito e democracia, Vol. 01, 2012, p. 138, 140, 157, 168 e 190; HABERMAS, Direito $e$ democracia, Vol. 02, 2011, p. 218 e 224.

${ }^{126}$ HABERMAS, Direito e democracia, Vol. 02, 2011, p. 218 e 234.

${ }^{127}$ BITTAR, A discussão do conceito de direito, 2005, p. 823.

${ }^{128}$ BITTAR, A discussão do conceito de direito, 2005, p. 820; HABERMAS, Direito e democracia, Vol. 01, 2012 , p. 50.

${ }^{129}$ HABERMAS, Direito e democracia, Vol. 01, 2012, p. 133 e 138.

${ }^{130}$ HABERMAS, Direito e democracia, Vol. 01, 2012, p. 163 e 164; HABERMAS, Direito e democracia, Vol. 02, 2011, p. 24 e 45.
} 
públicas segue os processos linguisticos que tem lugar na esfera pública. Podem, assim, no aprendizado que acompanha a continuidade de sua experiência, atualizar, consolidar, renovar, reconstruir o sistema de direitos, legitimamente ${ }^{131}$.

A ampliação do círculo de cidadãos capazes de falar e agir, envolvidos no processo cooperativo de interpretação pública das experiências sociais, conferindo-lhes sentido e dando-lhes solução, no âmbito do Estado de Direito - assim também permanentemente reconfigurado - aparece como fator central que dá a medida da qualidade da democracia e do direito democraticamente gerado. Uma qualidade aferida em termos racionaisdiscursivos ${ }^{132}$. Já se disse, com Habermas, “o nível discursivo do debate público constitui a variável mais importante"133.

5.5. De qualquer forma, ainda na linha dos referenciais teóricos, é de se destacar que tal configuração discursiva da democracia não sugere uma ambiência homogênea, com rígida conformação ética, organicamente autodirigida.

Cumpre reconhecer que a rede de comunicação que sobressai da experiência democrática não remete à sociedade econômica liberal, individualista, cujo paradigma é o mercado capitalista e na qual a ideia do todo não diz mais que a somatória de indivíduos atomizados que lutam separadamente por seus fins egoístas, incongruentes uns com os outros $^{134}$. Mas também não induz um percurso comunicativo que, de acordo com uma abordagem comunitarista republicana, caminha diretamente do autoentendimento ético de um ator coletivo para a autoadministração política do Estado. Não se negligencia, portanto, quanto ao momento intermediário do exercício (incerto) da liberdade comunicativa no espaço público e da pluralidade de vozes e interesses em conflito que nele tem lugar ${ }^{135}$.

A noção deweyana de público e, com ela totalmente compatibilizada, a imagem da esfera pública ocupada pela sociedade civil - extraída de Habermas -, funcionam, nessa matéria, como componente teórico fundamental, empiricamente referido à práxis social. Permitem identificar, no movimento dialético entre o indivíduo e seu ambiente social, o

\footnotetext{
${ }^{131}$ HABERMAS, Direito e democracia, Vol. 02, 2011, p. 115.

132 BITTAR, Justiça e emancipação, 2011, p. 584; HABERMAS, Direito e democracia, Vol. 01, 2012, p. 278; HABERMAS, Direito e democracia, Vol. 02, 2011, p. 100.

${ }^{133}$ HABERMAS, Direito e democracia, Vol. 02, 2011, p. 28.

134 HONNETH. Democracy as reflexive cooperation, 1998, p. 767; FRIEDMAN, Milton. Capitalismo e Liberdade. Trad. Luciana Carli. São Paulo: Abril Cultural, 1984, p. 11.

${ }^{135}$ HONNETH. Democracy as reflexive cooperation, 1998, p. 770, 771 e 774.
} 
protagonismo dos sujeitos históricos na transformação do status quo. Isso, num percurso gradual, complexo, conflituoso, contingencial, em que os processos de aprendizagem e desenvolvimento da personalidade vão de par com os de reconstrução e reforma social ${ }^{136}$.

De acordo com Dewey, é a existência de dificuldades no curso da experiência que movimenta o pensar, como atividade mental solucionadora de problemas ${ }^{137}$. À luz do pragmatismo, a reflexão não se dicotomiza da ação ${ }^{138}$. No curso da interação social, os sujeitos enfrentam problemas, são atingidos por consequências invasivas do comportamento alheio, vivenciam conflitos. Tais perturbações atuam prática e emocionalmente sobre as pessoas, funcionando como "choques de mudança, devidos à interrupção de um ajustamento (mental) prévio. São sinais para o redirecionamento da ação". Tem aí espaço para o pensamento ${ }^{139}$.

A partir daí, a experiência e a elaboração das dificuldades, no horizonte da biografia particular dos sujeitos privados, podem imbricar-se com outras tantas biografias individuais, de modo a, no âmbito da história plural "que contamos sobre nós mesmos" "140, superar a esfera privada e alcançar os canais comunicativos de esferas públicas cada vez mais amplas. Com esse fluxo comunicacional, os atores sociais podem, fazendo uso de sua liberdade comunicativa, encontrar-se, mobilizando e diferenciando a sociedade civil autônoma - baseada em associações, agrupamentos e movimentos sociais -, que não se confunde com o Estado nem com a economia. Reconhece-se e se delineia, processual e experimentalmente, o espaço, os temas, as pretensões, as interpretações, as opiniões e as vontades do público $^{141}$.

Tudo isso, de qualquer forma, na contradição de perspectivas, interesses, orientações axiológicas e teleológicas, referidos a grupos específicos, formas de vida particulares e histórias de vida individuais ${ }^{142}$. A imagem proposta por Habermas,

\footnotetext{
${ }^{136}$ MEAD, Mind, self and society, 1992, p. 214 e 309.

${ }^{137}$ DEWEY, John. How we think. Mineola, New York: Dover Publications, 1997, p. 09.

${ }^{138}$ FREIRE, Paulo. Educação e mudança. Trad. Moacir Gadotti e Lilian Lopes Martin. Rio de Janeiro: Paz e terra, 1979, p. 18.

${ }^{139}$ DEWEY, Reconstruction in philosophy, 2004, p. 50 e 51.

${ }^{140}$ RICOEUR, Paul. O Justo. A justiça como regra moral e como instituição. . Tomo 01. Trad. Ivone C. Benedetti. São Paulo: Martins Fontes, 2008, p. 25 e 28.

${ }^{141}$ DEWEY, The public and its problems, 1991, p. 34 e 35; HABERMAS, Direito e democracia, Vol. 02, 2011, p. 24

${ }^{142}$ HABERMAS, Consciência Moral e Agir Comunicativo. 2003, p. 148.
} 
aproximando-se das contribuições do também frankfurtiano Axel Honneth ${ }^{143}$, é de "luta por reconhecimento". Diz: "A controvérsia em torno de normas permanece arraigada, mesmo quando é conduzida com meios discursivos, na "luta pelo reconhecimento",144.

A concepção de discurso não se confunde com unanimidades espontâneas; não nega o dissenso, o conflito social de opiniões e interesses. Na realidade, o supõe. É em decorrência dele, do "não" à pretensão de validade trazida na oferta de fala, que o discurso se abre, afinal, como instância de apelação do agir comunicativo, entre aqueles que "precisam ser convencidos sem apelar para a força bruta" $" 145$.

É, aliás, em virtude dessa práxis comunicativa que se renova a cultura política, em meio à sua tradição; que se fortalecem os laços de cooperação, como decorrência da interação social; que os sujeitos se colocam, sob o aspecto da socialização, em condições de participação no universo de linguagem e nos processos de entendimento. Resumindo, é o agir comunicativo, com todo seu traço conflituoso - mas não por isso violento -, que possibilita a renovação dos componentes simbólicos do mundo da vida racionalizado e solidário $^{146}$.

Promovida, portanto, com o uso público da liberdade comunicativa e mediada pela comunicação pública levada a cabo pela sociedade civil $^{147}$, a atualização do processo democrático soma, à complexidade e elevado grau conflituoso, ora referidos, todo seu teor contingencial.

Com efeito, depende, primeiro, da experiência do problema, como tal, pelo sujeito, de modo a causar-lhe incômodo, perturbar seu equilíbrio, impulsionando-o à solução ${ }^{148}$. Honneth fala, aqui, do desrespeito que funciona como impulso motivacional que pode conduzir do sofrimento à ação ${ }^{149}$.

Depende, nesse sentido, da capacidade e, mais, da disposição comunicativa dos sujeitos para a exposição da questão em espaços públicos, pelos canais comunicativos de

\footnotetext{
${ }^{143}$ HONNETH, Axel. Luta por reconhecimento: a gramática moral dos conflitos sociais. 2ª ed. Trad. Luiz Repa. São Paulo: Editora 34, 2009.

144 HABERMAS, Consciência Moral e Agir Comunicativo. 2003, p. 128; HABERMAS, Direito $e$ democracia, Vol. 02, 2011, p. 41.

${ }^{145}$ HABERMAS, Consciência Moral e Agir Comunicativo. 2003, p. 126 e 128; HABERMAS, Direito e democracia, Vol. 02, 2011, p. 53; HABERMAS, Teoria do agir comunicativo, Tomo 01, 2012, p. 48.

${ }^{146}$ HABERMAS, Direito e democracia, Vol. 02, 2011, p. 91; HABERMAS, Teoria do agir comunicativo, Tomo 02, 2012, p. 252, 253 e 265.

${ }^{147}$ HABERMAS, Direito e democracia, Vol. 01, 2012, p. 186 e 190.

${ }^{148}$ DEWEY, How we think, 1997, p. 12.

${ }^{149}$ HONNETH, Luta por reconhecimento, 2009, p. 224.
} 
que dispõe, superando seu círculo privado, lançando-a ao debate, reivindicando o reconhecimento de suas pretensões, propondo interpretações e soluções.

Depende, ainda, de uma rede comunicacional aberta, ampla, "capaz de ressonância", de modo que o problema, inicialmente experienciado de forma particular, possa ser percebido no quadro de uma interpretação intersubjetiva, pública ${ }^{150}$. Novamente na linguagem de Honneth, implica um "processo prático no qual experiências individuais de desrespeito são interpretadas como experiências cruciais típicas de um grupo inteiro, de forma que elas podem influir, como motivos diretores da ação, na exigência coletiva por relações ampliadas de reconhecimento" ${ }^{151}$. Depende, pois, da capacidade de comunicação, de organização e de articulação de demandas da sociedade civil. Afinal,

Na perspectiva de uma teoria da democracia, a esfera pública tem que reforçar a pressão exercida pelos problemas, ou seja, ela não pode limitarse a percebê-los e a identificá-los, devendo, além disso, tematizá-los, problematizá-los e dramatizá-los de modo convincente e eficaz, a ponto de serem assumidos e elaborados pelo complexo parlamentar ${ }^{152}$.

E isso, sabendo-se de antemão que nem mesmo a inscrição de determinado tema na agenda política "significa necessariamente que a decisão final das autoridades ou que a atual política de implementação corresponderão às pretensões do grupo que formulara a demanda" $" 153$.

Enfim, no âmbito do emaranhado plural que define as interações sociais, não há qualquer relação de necessidade, de causalidade na atualização do fluxo comunicacional que vai da experiência individual do problema social à solução institucionalizada no âmbito do direito democrático ${ }^{154}$.

A formação da vontade no Estado Democrático de Direito, se supõe, num nível normativo, a "transmutação do poder comunicativo em administrativo", não a inscreve em nenhuma narrativa histórica que possa ir além daquela concretamente protagonizada pelos atores sociais. A prática de autodeterminação "não foge à história", exigindo, para sua concretização, que os sujeitos históricos não se furtem à "sua própria prática"155.

\footnotetext{
${ }^{150}$ HABERMAS, Direito e democracia, Vol. 02, 2011, p. 98 a 100.

${ }^{151}$ HONNETH, Luta por reconhecimento, 2009, p. 257.

${ }^{152}$ HABERMAS, Direito e democracia, Vol. 02, 2011, p. 92.

${ }^{153}$ HABERMAS, Direito e democracia, Vol. 02, 2011, p. 115.

${ }^{154}$ HABERMAS, A inclusão do outro, 2007, p. 290 e 291; HABERMAS, Direito e democracia, Vol. 02, 2011 , p. 23 e 24.

${ }^{155}$ HABERMAS, Direito e democracia, Vol. 01, 2012, p. 190; HABERMAS, Direito e democracia, Vol. 02, 2011, p. 122.
} 
5.6. É por não se perfazer sem a atualização, sempre renovada, do discurso, que a consolidação da democracia demanda a presença, de modo cada vez mais pleno, dos exigentes pressupostos da comunicação. Exige a aproximação da situação dialógica ideal e a competência e disposição comunicativa dos cidadãos, numa relação contínua de favorecimento recíproco ${ }^{156}$.

A situação ideal de fala remete a condições de simetria das quais, como destaca Habermas, supomo-nos aproximados satisfatoriamente, em nosso cotidiano, "quando desejamos convencer-nos mutuamente da validade de algo". Todo falante, "na medida em que pensa entrar de todo numa argumentação", tem de pressupô-las suficientemente preenchidas, mesmo que, em certa medida, de modo contrafático. Não há outro fundamento racional que justifique seu empreendimento ${ }^{157}$.

A vida social se realiza na comunicação. E se o uso ilocucionário da linguagem, orientada ao entendimento, não prevalece como modelo dominante de coordenação, sendo constantemente desalojado na experiência brasileira de desrespeito aos direitos humanos, ele persiste, sim, no agir comunicativo cotidiano, no horizonte do mundo da vida. $\mathrm{O}$ modelo discursivo se faz presente, ainda que indiretamente, como visto, mesmo nas negociações entre partidos e agentes que se orientam teleologicamente, no espaço público, valendo-se de promessas, seduções, ameaças, num uso perlocucionário da linguagem. Confere-lhes moralidade procedimental, revigorada como a única dimensão em que é possível assegurar à democracia e ao direito democrático "um momento de indisponibilidade e uma estrutura subtraída a intervenções contingentes"158.

Excluído o discurso e sua racionalidade, resta aos indivíduos a coordenação social pautada na violência, praticada sem disfarces ou palatável pela mediação de conversações de tal modo viciadas que perdem seu sentido - reduzidas, na observação precisa de

\footnotetext{
${ }^{156}$ FREITAG, A questão da moralidade, 1989, p. 37; HABERMAS, Direito e democracia, Vol. 02, 2011, p. 09.

157 HABERMAS, Consciência moral e agir comunicativo, 2003, p. 111; HABERMAS, Direito $e$ democracia, Vol. 01, 2012, p. 284; HABERMAS, Teoria do agir comunicativo, Tomo 01, 2012, p. 91.

158 HABERMAS, Consciência moral e agir comunicativo, 2003, p. 128; HABERMAS, Direito $e$ democracia, Vol. 01, 2012, p. 207 e 208; HABERMAS, Direito e democracia, Vol. 02, 2011, p. 246.
} 
Adorno, a "invólucros vazios do diálogo, cuja ideia foi um dia a de encontrar aquilo que não se sabia de antemão"159.

Contudo, evidentemente, não basta que a situação ideal de fala seja pressuposta, intuída. Ela deve ser institucionalizada no medium do direito, de forma que - fundida a estrutura comunicativa nos ambientes e procedimentos democráticos - resguarde a participação efetiva e esclarecida do cidadão, em igualdade de condições, nos processos, informais e institucionais, de formação da opinião e da vontade ${ }^{160}$.

Desse modo, a situação dialógica pressuposta pela experiência democrática passa pela afirmação dos direitos humanos, constitucionalmente reconhecidos, em toda sua extensão - as liberdades subjetivas, os direitos políticos, sociais e transindividuais. Refletese, então, nos instrumentos de exercício da soberania popular: o sufrágio universal; o voto direto com valor igual para todos; e os instrumentos participativos previstos no Art. 14, da Constituição.

Entretanto, deve superar as condições de simetria na participação meramente eleitoral ou em plebiscitos, referendos e na assinatura de projetos de lei. A democracia que vai além da formalidade do voto ${ }^{161}$ envolve, como se destacou, a efetivação de ambientes comunicativos cada vez mais ampliados que incrementem, sob a forma constitucional, a intersubjetividade da inclusão do outro, como parceiro de comunicação e, na práxis comunicativa, do direito.

Exige, portanto, uma estruturação dialógica que percorra os espaços da sociedade civil e, assim, configurando as redes informais da esfera pública, atravesse as "comportas do processo democrático e do sistema político em geral, instauradas na forma de Estado de direito" ${ }^{162}$. Deve-se refletir, nessa linha, nos ambientes sociais precedentes à atuação do sistema político, irradiando a forma democrática à organização dos movimentos e agrupamentos populares; às associações de bairro; às organizações e partidos políticos; às organizações econômicas, inclusive, com a participação dos empregados na gestão do empreendimento; aos ambientes educacionais informais e formais, passando pelas

\footnotetext{
159 ADORNO, Theodor. W. Prismas: crítica cultural e sociedade. Trad. Augutin Wernet e Jorge Mattos Brito de Almeida. São Paulo: Ática, 1998, p. 97.

${ }^{160}$ HABERMAS, Direito e democracia, Vol. 01, 2012, p. 146; HABERMAS, Direito e democracia, Vol. 02, 2011, p. 42; DAHL, Robert A. A democracia e seus críticos. Trad. Patrícia de Freitas Ribeiro. Revisão da tradução: Aníbel Mari. São Paulo: Editora WMF Martins Fontes, 2012, p. 176.

${ }^{161}$ DALLARI, Educação e preparação para a cidadania, 2009, p. 345.

${ }^{162}$ HABERMAS, Direito e democracia, Vol. 02, 2011, p. 56.
} 
agremiações estudantis, pelas associações de pais e mestres e pela administração escolar, em todos os níveis. Finalmente, a situação dialógica deve estruturar o funcionamento do aparelho governamental, assegurando a participação social por meio dos conselhos e comissões de política pública, das audiências e consultas públicas, das ouvidorias, do orçamento participativo, dentre tantas outras possibilidades de experimentação da democracia $^{163}$.

Todos esses ambientes devem amparar, ao máximo, a práxis argumentativa, livre de violência e coações, "regulada pelos melhores argumentos, na base das melhores informações". E, desse modo, permitir a afirmação do discurso e a atualização de seu potencial racional comunicativo, na forma de debates morais, éticos e pragmáticos ou, sendo esta a alternativa, de negociações equitativas ${ }^{164}$.

A consolidação, o fortalecimento e a ampliação desses procedimentos e ambientes configurados discursivamente remetem, ainda, à sua ocupação e exercício, no continuum experiencial enriquecedor de si, por atores sociais com competência e disposição comunicativa.

A democracia requer cidadãos que, como resultado de um processo educativo de desenvolvimento da competência cognitiva e, num nível pós-convencional, da consciência moral, mostram-se capazes e dispostos à participação nos processos linguisticos de entendimento, no espaço público democrático.

Demanda, por conseguinte, a formação de sujeitos com hábitos reflexivos de pensar, agir e conviver que, como destaca Dewey, assimilem a atitude científica, caracterizada pela disposição investigativa, experimental, metódica, falibilista, no enfrentamento de problemas com que se depara na experiência. Afinal, para o autor, o "futuro da democracia está associado à difusão da atitude científica". Mas isso não equivale, absolutamente, à pretensão de que todos os cidadãos sejam cientistas. Tampouco à defesa de um governo tecnocrático ${ }^{165}$.

\footnotetext{
163 WEFFORT, Por que democracia?, 1984, p. 125; BENEVIDES, A cidadania ativa, 2003, p. 18; BENEVIDES, Em defesa da república e da democracia, 2009, p. 728.

${ }^{164}$ HABERMAS, Direito e democracia, Vol. 01, 2012, p. 284.

${ }^{165}$ DEWEY, Freedom and culture, 1989, p. 81, 111, 112 e 114.
} 
Aqui, o pensamento deweyano converge com o de Habermas, no sentido de que também a atuação do cientista ou do especialista, na democracia, deve se efetivar na condição de participante do discurso. Ele não fala de qualquer posição privilegiada. Não está imune às tomadas de posição, à crítica a pretensões de validade, à exigência de fundamentação. É no âmbito da linguagem comum que circula em toda sociedade e da práxis comunicativa voltada ao entendimento, no horizonte do mundo da vida, que o cientista faz incorporar suas contribuições ao debate e à interpretação pública das experiências e problemas comuns. Pode, assim, incrementar a qualidade técnico-científica das soluções propostas, elevando o nível em que a racionalidade, a inteligência do público opera $^{166}$.

Ademais, nessa mesma linha, a democracia exige que os atores sociais exercitem sua competência cognitiva no âmbito do agir comunicativo. Tal competência precisa ser expressa em termos racionais-comunicativos da resgatabilidade discursiva de pretensões de validade que orientam o agir ${ }^{167}$.

A qualidade racional da experiência democrática e a legitimidade do processo legislativo dependem do habitual uso público da liberdade comunicativa pelos cidadãos, abrindo-se, responsavelmente, às exigências da argumentação no espaço público, e, nele, atualizando os potenciais discursivos na construção cooperativa da verdade e da moral.

É aí, na comunicação pública, que reside o exercício democrático da soberania popular. Faz-se como experiência intersubjetiva da autonomia que une liberdade e razão, teórica e prática, na práxis comunicativa. Uma liberdade, portanto, com responsabilidade, impregnada de obrigações inerentes aos processos linguísticos voltados ao entendimento mútuo $^{168}$.

Tudo isso, sabendo-se de antemão que o Estado Democrático de Direito e as liberdades subjetivas nele garantidas possibilitam, também, que o sujeito, a qualquer tempo, abandone a orientação ao entendimento, adotando o enfoque estratégico e o uso perlocucionário da linguagem. Ele pode, simplesmente, renunciar ao uso da liberdade

\footnotetext{
166 DEWEY, The public and its problems, 1991, p. 207 e 210; HABERMAS, Consciência Moral e Agir Comunicativo. 2003, p.43 e 117; HABERMAS, Teoria do agir comunicativo, Tomo 01, 2012, p. 138; HABERMAS, Direito e democracia, Vol. 01, 2012, p. 276.

${ }^{167}$ HABERMAS, Verdade e justificação, 2009, p. 102; HABERMAS, Teoria do agir comunicativo, Tomo 01,2012 , p. 35, 47 e 48.

${ }^{168}$ DEWEY, Ethics, 2008, p. 305; HABERMAS, Verdade e justificação, 2009, p. 102; HABERMAS, Direito e democracia, Vol. 02, 2011, p. 24.
} 
comunicativa, pode sair do agir comunicativo, orientando-se ao sucesso individual e, ainda assim, atuar conforme o direito, que, restrito ao aspecto exterior do agir, libera dos motivos do comportamento legal ${ }^{169}$.

De qualquer forma, é somente a experiência comunicativa da democracia - com toda sua incerteza - que pode neutralizar as distorções que a tem minado, num contexto historicamente construído sobre o não-diálogo, a imposição e o desrespeito aos direitos humanos, e marcado pela exclusão social, pela violência, pela fragilidade dos laços de cooperação e pela contaminação e manipulação sistêmica dos processos linguísticos no mundo da vida. Um contexto, enfim, que produz poder ilegítimo na extensão em que evita o discurso, que diminui o nível discursivo do debate, afastando a formação da opinião e da vontade do entendimento linguístico ${ }^{170}$.

5.7. Eis o modo como se apreende a democracia sob a perspectiva filosófica de Dewey e de Habermas: um modelo de auto-organização em que pode ter lugar o projeto inacabado de modernidade. Apoiada no discurso, afirma-se como práxis social em que se efetiva a autonomia comunicativamente compreendida. E, assim, resguarda o eu que, socialmente constituído, somente se realiza em relação com o nós.

O discurso que abre "caminho para a entrada da racionalidade moral procedimental no direito e na política" ${ }^{171}$ traz consigo o potencial cognitivo e prático de enriquecimento permanente do saber produzido. Faz da autodeterminação democrática o caminho para a racionalidade das decisões coletivas sobre conflitos de coordenação social. Afinal, quanto maior o número de participantes competentes incluídos na conversação, em condições de igualdade, maiores as chances de respostas inteligentemente construídas e compartilhadas às situações problemáticas vivenciadas pelo grupo social ${ }^{172}$.

Fica definida, portanto, no âmbito da filosofia social, a relação próxima, urdida na linguagem, entre democracia, política, direito, razão e moral.

${ }^{169}$ HABERMAS, Teoria do agir comunicativo, Tomo 02, 2012, p. 279; HABERMAS, Direito e democracia, Vol. 01, 2012, p. 51, 115 e 156; HABERMAS, Direito e democracia, Vol. 02, 2011, p. 217.

${ }^{170}$ DEWEY, The public and its problems, 1991, p. 169; HABERMAS, Direito e democracia, Vol. 01, 2012, p. 207; HABERMAS, Direito e democracia, Vol. 02, 2011, p. 56, 97, 114, 115, 121 e 122.

${ }^{171}$ HABERMAS, Direito e democracia, Vol. 02, 2011, p. 247.

${ }^{172}$ HONNETH, Democracy as reflexive cooperation, 1998, p. 772, 773 e 775. 
6. Frente ao desafio da consolidação democrática no Brasil, legado do passado autoritário que sobrecarrega o presente de tarefas democratizantes, descortina-se, à luz da filosofia social de Dewey e de Habermas, a atuação não exclusiva, mas fundamental, da educação ${ }^{173}$.

Destaca-se: a educação entendida em sentido bastante ampliado, referida ao tecido inesgotável de experiências comunicativas que compõem a vida ${ }^{174}$. Remete, conforme a Lei de Diretrizes e Bases, o $3^{\circ}$ Plano Nacional de Direitos Humanos e o Plano Nacional de Educação em Direitos Humanos, aos processos formativos que tem lugar em todos os âmbitos da convivência humana: na vida familiar e privada; no trabalho; na participação nos procedimentos políticos, indiretos e diretos, institucionalizados na Constituição; no envolvimento em movimentos populares e em associações da sociedade civil; na vida cultural; no lazer; e na escola, como espaço institucionalmente voltado à transmissão formal e sistematizada do saber cultural ${ }^{175}$.

A reflexão sobre a educação impõe-se, aqui, na medida em que a consolidação da democracia é concebida a partir de sua experiência e reconstrução de sua experiência, no medium jurídico, carente de interpretação, instituído pelo texto constitucional de 1988. Noutros termos, na medida em que a democracia, como uma forma comunicativa de vida, não prescinde de processos de aprendizagem ${ }^{176}$.

O fim da era das "revoluções sistêmicas", referido por Bauman ${ }^{177}$, aparece, no final das contas, como exigência prática da abertura do pensamento filosófico aos ensinamentos da psicologia social. Não se distinguindo mais, em linhas nítidas, da psicologia individual $^{178}$, ela não negligencia quanto à força das experiências sociais na formação e renovação dos hábitos de pensar, agir e conviver, por meio dos quais tais experiências

\footnotetext{
173 SCHILLING, Flávia. O que cabe à educação fazer em direitos humanos? VI Encontro Anual da Associação Nacional de Direito Humanos - Pesquisa e Pós-graduação - ANDHEP, Brasília/DF, 17/09/2010.

174 TEIXEIRA, Anísio S. A pedagogia de Dewey (Esboço da teoria de educação de John Dewey). In DEWEY, John. Experiência e natureza; Lógica: a teoria da investigação; A arte como experiência; Vida e educação; Teoria da vida moral. Trad. Murilo Otávio Rodrigues Paes Leme, Anísio S. Teixeira e Leônidas Gontijo de Carvalho. Coleção Os Pensadores. São Paulo: Abril Cultural, 1980, p. 115.

${ }^{175}$ COMITÊ NACIONAL DE EDUCAÇÃO EM DIREITOS HUMANOS. Plano Nacional de Educação em Direitos Humanos. Brasília: Secretaria Especial dos Direitos Humanos/Ministério da Educação/Ministério da Justiça/UNESCO, 2007, p. 31 e 43. Disponível em: http://portal.mj.gov.br/sedh/edh/pnedhpor.pdf. Acesso em 23/01/2014.

${ }^{176}$ DEWEY, Freedom and culture, 1989, p. 97 e 101; MOISÉS, Os brasileiros e a democracia, 1995, p. 55 e 77.

${ }^{177}$ BAUMAN, Zygmunt. A modernidade líquida. Trad. P. Dentzien. Rio de Janeiro: Jorge Zahar, 2001, p. 12. ${ }^{178}$ MEAD, Mind, self and society, 1992, p. 01 e 02.
} 
podem ser transformadas, recorrendo-se justamente aos aprendizados e instrumentos por meio dela construídos. Nesse sentido, evidencia a dificuldade de se insistir, sem mais, em transformações profundas e imediatas, de uma só vez, criando a nova ordem social, a partir de uma tabula rasa ${ }^{179}$. Indica, enfim, a mudança social que, no continuum experiencial, atinge, sim, de forma radical, as estruturas sistêmicas, mas porque pode se institucionalizar comunicativamente nos componentes estruturais do mundo da vida racionalizado e "descolonizado": na tradição cultural criticamente revisitada, nas ordenações sociais discursivamente resgatáveis e solidárias e em personalidades racionalmente formadas ${ }^{180}$. Isso, como já destacado, num processo comunicativo conflituoso e contingencial. Novamente com Bauman:

Se o tempo das revoluções sistêmicas passou, é porque não há edifícios que alojem as mesas de controle do sistema, que poderiam ser atacados e capturados pelos revolucionários; e também porque é terrivelmente difícil, para não dizer impossível, imaginar o que os vencedores, uma vez dentro dos edifícios (se os tivessem achado), poderiam fazer para virar a mesa e pôr fim à miséria que os levou à rebelião ${ }^{181}$.

Diante desse quadro, pensar a educação para a democracia, no Brasil, com base em Dewey e em Habermas, demanda o reconhecimento da tarefa extremamente complexa e delicada a que se propõe. Não permite o descuido quanto à força das condições objetivas de existência, dos hábitos enraizados, das antigas instituições ${ }^{182}$, em resumo, do "poder que a realidade extrapedagógica exerce" ${ } 183$, determinando, em grande medida, as possibilidades da educação. Exige a atenção ao fato de que a aprendizagem tem de se atualizar e se renovar num contexto em que a inexperiência democrática e os déficits de direitos humanos tendem a indicar o sentido experiencial oposto, deseducativo em relação à democracia.

Por outro lado, não deixa de reconhecer os espaços educacionais, formais e informais, como "nichos" de razão comunicativa, em que a democracia pode ser vivenciada, fortalecida, consolidada ${ }^{184}$. Como destacado na filosofia habermasiana, a colonização do mundo da vida pelos imperativos sistêmicos enfraqueceu, contaminou, mas

\footnotetext{
${ }^{179}$ DEWEY, The public and its problems, 1991, p. 162

${ }^{180}$ BERNSTEIN, The resurgence of pragmatism, 1992, p. 815; FREITAG, Bárbara. A teoria crítica: ontem e hoje. São Paulo: Brasiliense, 2004, p. 62.

${ }^{181}$ BAUMAN, A modernidade líquida, 2001, p. 12.

182 DEWEY, The public and its problems, 1991, p. 161.

183 ADORNO, Theodor W. Teoria da semicultura. Trad. por Newton Ramos de Oliveira, Bruno Pucci e Cláudia B. M. de Abreu. Educação \& Sociedade nº 56, ano XVII, dez/1996.

${ }^{184}$ FREITAG, A teoria crítica, 2004, p. 62.
} 
não extinguiu a práxis comunicativa cotidiana ${ }^{185}$. Nessa linha, tampouco a crítica e a capacidade de crítica, imanente ao potencial racional dos processos linguísticos, foram varridas da sociedade ${ }^{186}$.

Nesses espaços comunicativos, entreveem-se perspectivas emancipatórias, no âmbito da revisita crítica ao projeto moderno inacabado, a partir de experiências educativas que, desenvolvidas em condições democráticas, ainda que precárias, podem desencadear um movimento enriquecedor de si. E isso, por meio da atuação dos próprios atores sociais envolvidos no processo democrático, aproveitando, mais uma vez, a potencialidade de sentidos latentes na Constituição de 1988. Sem sabotar as possibilidades de ação e transformação social e sem recorrer a metahistórias, portanto ${ }^{187}$.

6.1. Nessa tarefa, toma-se por educação, com base no pensamento dos dois filósofos, o processo de constituição da individualidade, na socialização, orientado ao desenvolvimento pleno do educando, em suas diversas dimensões como pessoa, no desenrolar experiencial e no desabrochar intelectual e moral de sua reflexão, ação e interação no mundo.

Realizada na comunicação, habilita e dispõe racionalmente ao agir comunicativo e à práxis discursiva, de modo que o educando possa aproveitar, sempre mais, seus potenciais racionais teóricos e práticos, na condução de suas experiências.

Trata-se, dessa maneira, de um percurso formativo da personalidade individual, única e irrepetível, que, atualizado de modo eminentemente social, é atravessado, comunicativamente, pelos demais processos de renovação dos componentes simbólicos do mundo da vida racionalizado: a renovação crítica do saber cultural e a integração social pautada em laços de solidariedade e cooperação ${ }^{188}$.

Remete, assim, ao crescimento geral $^{189}$, na contínua ampliação e enriquecimento das experiências, recíproca e complementarmente referidas ao mundo subjetivo da pessoa

${ }^{185}$ NOBRE, Marcos. Luta por reconhecimento: Axel Honneth e a teoria crítica. In HONNETH, Axel. Luta por reconhecimento: a gramática moral dos conflitos sociais. Trad. Luiz Repa. São Paulo: Editora 34, 2009, p. 14; HABERMAS, Teoria do agir comunicativo, Tomo 02, 2012, p. 595 e 601.

${ }^{186}$ BAUMAN, A modernidade líquida, 2001, p. 30 e 31.

187 HABERMAS, Direito e democracia, Vol. 01, 2012, p. 157 e 167; ADORNO, Theodor, W. Escritos sociológicos I. Obra completa 08. Trad. Agustín González Ruiz. Madrid, España: Akal, 2004, p. 132.

${ }^{188}$ MEAD, Mind, self and society, 1992, p. 201; HABERMAS, Teoria do agir comunicativo, Tomo 02, 2012, p. 78, 252, 253 e 260 .

189 DEWEY, Reconstruction in philosophy, 2004, p. 106 e 107; DEWEY, Experiência e educação, 2010, p. 36, 37 e 48. 
em crescimento e ao universo exterior, nele refletido. Na interação com o ambiente social, mediada pela linguagem - pensando, agindo, reagindo e sendo submetido à atuação dele o sujeito reorganiza permanentemente seu inventário e recursos cognitivos. Pode, assim, expandir e aprofundar o significado de suas experiências. Pode, então, desenvolver a habilidade de um melhor, mais adequado controle e direção do curso das experiências objetivas e sociais subsequentes, em termos cognitivos e morais, sob o paradigma da racionalidade comunicativa ${ }^{190}$.

Pode, em suma, desenvolver competências e hábitos de pensar, agir e conviver, dispondo-se ao discurso - e não à coação, à violência, ao engodo - como instância de solução de problemas enfrentados no curso experiencial, de construção cooperativa do saber e de prestação de contas das pretensões de validade que orientam seu agir comunicativo. Em termos morais, o educando atravessa a heteronomia convencional e alcança o estágio da autonomia pós-convencional, referido à práxis discursiva. Capacita-se, enfim, à intersubjetividade que marca a experiência democrática.

O reconhecimento da ambiência dialógica da democracia como o lugar da atualização do projeto emancipatório de modernidade, exige, como visto, a instituição de espaços, mecanismos e procedimentos participativos, diretos e indiretos, no âmbito do Estado Democrático de Direito. Eles configuram aproximativamente a situação ideal de fala. E demanda, também, seu exercício por atores sociais com competência e disposição comunicativa, ocupando esses espaços, efetivando tais procedimentos, ampliando e consolidando todos eles. A educação cumpre, aqui, papel central. Na leitura dos objetivos constitucionais da educação, amparada na filosofia de Dewey e de Habermas, o pleno desenvolvimento da pessoa se liga ao preparo para o exercício da cidadania. Confundemse com educação na e para a democracia.

6.2. A experiência educativa, com tal significação, concebida sob a perspectiva da filosofia social dos dois autores, abrange as seguintes diretrizes.

${ }^{190}$ DEWEY, Reconstruction in philosophy, 2004, p. 49; DEWEY, John. Democracy and education. An introduction to the philosophy of education. New York: The Macmillan Company, 1916, p. 63, 89 e 90. 
i) Educação dialógica. A abordagem filosófica comunicativa da formação da personalidade e da construção do saber e da moralidade demanda que a experiência educativa - tal como a democrática - assuma, como paradigma, o discurso, a linguagem voltada ao entendimento mútuo.

É a partir da experiência renovada do diálogo, em condições cada vez mais efetivas e plenas de sentido, que o sujeito em crescimento pode, internalizando-a, habilitar-se e habituar-se à sua práxis competente. Se, por um lado, certamente, o diálogo entre atores comunicativamente competentes não se dará entre professor e alunos do ensino infantil; por outro, é só como resultado do processo de aprendizagem, progressivamente dialógico, que se pode conceber a interação que dele se aproxime.

É significativa, nesse ponto, a reflexão de D. Saviani em que, definindo o processo educativo como a "passagem da desigualdade para a igualdade", concebe-o como democrático, em seu conjunto, sob a condição de se distinguir "a democracia como possibilidade no ponto de partida e a democracia como realidade no ponto de chegada". $\mathrm{O}$ aforismo por ele utilizado, “democracia é uma conquista; não um dado", estende-se à competência comunicativa que constitui um de seus exigentes pressupostos ${ }^{191}$.

É verdade, a constituição da personalidade passa, inevitavelmente, pela comunicação. Por meio dela, o mundo vem a nós vestido em linguagem, em suas versões discursivas. A partir dela, participando do outro e das expectativas, valores, orientações que moldam seu olhar, experienciamos a nós mesmos. Constituímo-nos, reflexivamente, como autoconsciência, cujo pensar - na conversa consigo mesmo - e agir refletem a conversa com os outros e as atitudes deles (que internalizamos), em relação a nós ${ }^{192}$.

Por isso, o cenário social e, dentro dele, as instituições e os espaços educativos, em que a linguagem está comprometida - contaminada pela racionalidade instrumental deformada, viciada por padrões de unilateralidade e autoritarismo, orientada a fins perlocucionários - favorecem e reforçam a constituição de uma individualidade "hospedeira" da atitude solipsista, objetivante em relação ao outro, da unilateralidade, da

${ }^{191}$ SAVIANI, Dermeval. Escola e democracia. Edição comemorativa. Campinas: Autores associados, 2008, p. 62.

${ }^{192}$ MEAD, Mind, self and society, 1992, p. 47, 50, 134, 141 e 171; DEWEY, Reconstruction in philosophy, 2004, p. 54; 
arbitrariedade e do uso parasitário da linguagem. Afinal, "Estes são o seu testemunho de humanidade" ${ }^{, 193}$.

Tal é a crítica que se impõe às práticas bancárias de educação ${ }^{194}$ que, assim intituladas por Paulo Freire, remetem ao modelo pedagógico tradicional - a que Dewey se contrapõe -, fundado na transmissão unilateral de informações ao educando e na imposição, com soluções preditas, de um mundo experiencial que nem sequer fora problematizado.

A competência e a disposição comunicativa dificilmente podem emergir dessa experiência imunizada contra o discurso. Não podem ser ensinadas na teoria, em termos abstratos que não encontram correspondência na prática. É um contrassenso pensar a institucionalização do diálogo - e, na vida pública democrática, a participação cidadã -, a partir de um sentido não experimentado; no mais das vezes, negado na práxis cotidiana. Afinal, como ressalta Kohlberg, citando F. Newmann:

(...) tem de haver coerência entre os princípios da democracia ensinados e o processo efetivo de educação ou os estudantes se converterão em destruidores tanto dos princípios democráticos ensinados como do processo de educação. A educação deve autenticar esses princípios centrais da democracia e aplicá-los ao processo educativo ${ }^{195}$.

Pensado, em contrapartida, como momento privilegiado do agir comunicativo ${ }^{196}$, o processo educacional se abre à bilateralidade e horizontalidade da linguagem utilizada em seu modo original e voltada, pois, ao telos de entendimento. Constitui e habitua a personalidade dentro de referencial, o discursivo, que traz inesgotável potencial racional de aprendizagem, teórica e moral, justamente por incluir o outro e seu universo experiencial $^{197}$.

A comunicação linguística - disse-se - implica uma perspectiva existencial participante. Abre-se ao outro como parceiro de comunicação que, em sua diferença, compartilha o significado do que foi dito, mas pode, também, recusar a oferta de fala com

\footnotetext{
${ }^{193}$ FREIRE. Paulo. Pedagogia do oprimido. $50^{\mathrm{a}}$ ed. Rio de Janeiro: Paz e Terra, 2011, 43 e 44.

${ }^{194}$ FREIRE, Pedagogia do oprimido, 2001, p. 82.

195 KOHLBERG, Lawrence. La Democracia en la escuela secundaria: educando para una sociedad mas justa. Trad. Maria Mercedes Oraison. Chaco: Universidad Nacional del Nordeste, 1992, p. 29.

196 BOUfLEUER, José Pedro. Pedagogia da ação comunicativa. Uma leitura de Habermas. $3^{\text {a }}$ ed. Ijuí: Unijuí, 2001, p. 17.

${ }^{197}$ HABERMAS, Teoria do agir comunicativo, Tomo 01, 2012, p. 49, 57, 498 e 500.
} 
seu "não"; pode criticar a pretensão de validade nela contida, demandando fundamentação ${ }^{198}$.

Desse modo, sob a abordagem comunicativa, a aprendizagem é compreendida no âmbito de um processo linguístico - e hermenêutico - compartilhado, em que são conferidos e renovados os sentidos das situações intersubjetivamente vividas. Experiências que perpassam os fatos e entidades que compõem o mundo objetivo único, as normas do mundo social compartilhado por nós, e o mundo subjetivo a que cada um tem acesso privilegiado $^{199}$.

$\mathrm{Na}$ oposição, complementaridade e similaridade de enfoques e recortes da realidade, as individualidades são linguisticamente formadas e reconstruídas, sob a moldura racional comunicativa. Ao mesmo tempo, apontados os equívocos do solilóquio da razão falível e vencidos particularismos semânticos, o saber e os significados ensinados - oriundos do reservatório do mundo da vida ou gerados no campo das ciências, das técnicas, da moral, da $\operatorname{arte}^{200}$ - são ampliados e enriquecidos, na extensão em que compartilhados, criticados, revisitados, fundamentados, corrigidos; na extensão em que se atualizam, enfim, como uma "comunidade de participação"201.

Daí a convergência, na experiência educativa, entre os processos de renovação dos componentes estruturais do mundo da vida racionalizado. A formação de personalidades racionais, na socialização, caminha junto, pela via do agir comunicativo, com a transmissão e revisita crítica das tradições culturais e dos padrões normativos e axiológicos do grupo social.

Eis o sentido profundo do potencial cognitivo e prático/consumatório trazido, com o discurso, para a experiência educativa. Induz o entendimento como processo linguístico de unificação que não prescinde da individualidade particular de cada um. Constrói e compartilha o conteúdo processual e falível da verdade e da moral que, comunicativamente, somente encontra fundamentação na razão: "nenhuma das partes jamais pode impô-lo",202.

\footnotetext{
${ }^{198}$ DEWEY, Experiência e natureza, 1980, p. 36 e 40; OLIVEIRA, Escola e sociedade, 1989, p. 23; MEAD, Mind, self and society, 1992, p. 327; HABERMAS, Consciência moral e agir comunicativo, 2003, p. 43.

${ }^{199}$ HABERMAS, Teoria do agir comunicativo, Tomo 01, 2012, p. 37 e 138.

${ }^{200}$ HABERMAS, Consciência moral e agir comunicativo, 2003, p. 32, 33, 166 e 167; HABERMAS, Teoria do agir comunicativo, Tomo 02, 2012, p. 227.

${ }^{201}$ DEWEY, Experiência e natureza, 1980, p. 29, 40 e 51.

${ }^{202}$ HABERMAS, Teoria do agir comunicativo, Tomo 01, 2012, p. 498.
} 
ii) Desenvolvimento da capacidade cognitiva. A promessa cognitiva vinculada à comunicação linguística ${ }^{203}$, entre atores competentes, não se realiza sem o desenvolvimento intelectual da personalidade, constituída dialogicamente.

$\mathrm{Na}$ filosofia educacional deweyana, o crescimento cognitivo corresponde ao desenvolvimento de hábitos reflexivos de pensamento, tomado o pensar, num sentido pragmatista, de modo necessariamente vinculado e comprometido com a práxis. Retomase: para o autor, o pensar em seu melhor sentido, o reflexivo, apresenta-se como um processo complexo de solução de problemas enfrentados no curso da experiência. Passa, então, pela sugestão de uma solução, valendo-se do "estoque" de conhecimentos, habilidades e experiências que já compõem o inventário cognitivo da pessoa. E termina com experimentação prática da resposta idealmente inferida ${ }^{204}$.

A inteligência, desse modo, refere-se menos à quantidade de informações depositadas na mente do educando; mais a sua habilidade de, por meio do pensar, resolver as dificuldades e questões presentes em sua experiência, a partir daquele "estoque" - de qualquer forma necessário -, de modo a perceber as relações e as continuidades entre os eventos e coisas; reconhecer possibilidades; significar os objetos e situações, em termos pragmatistas, referindo o presente às consequências futuras, considerando as experiências do passado $^{205}$.

Abrange, assim, a atitude científica tão destacada por Dewey, que nada tem a ver com o cientificismo, com a "cultura de especialistas", com o culto dogmático dos conteúdos científicos. Indica a atuação da razão, do pensamento solucionador de problemas, de modo ativo, investigativo, metódico, experimental e criativo ${ }^{206}$. Tudo isso na condição de participante na práxis comunicativa da busca cooperativa da verdade ${ }^{207}$.

\footnotetext{
${ }^{203}$ DEWEY, Verdade e justificação, 2009, p. 71.

204 JOAS, Pragmatism and social theory, 1993, p. 18; DEWEY, How we think, 1997, p. 11, 12 e 72; DEWEY, Reconstruction in philosophy, 2004, p. xxv e 94; DEWEY, Experiência e educação, 2010, p. 70.

${ }^{205}$ MEAD, Mind, self and society, 1992, 100 e 116; DEWEY, Experiência e natureza, 1980, p. 38 e 39 ; DEWEY, Experiência e educação, 2010, p. 69 e 70.

${ }^{206}$ MEAD, Mind, self and society, 1992, 308; DEWEY, Freedom and culture, 1989, p. 111; DEWEY, Reconstruction in philosophy, 2004, p. 55.

${ }^{207}$ JOAS, Pragmatism and social theory, 1993, p. 19 e 20.
} 
Da mesma forma que a comunicação linguística que o promove, o desenvolvimento cognitivo somente tem lugar a partir de sua experiência ativa, ao longo do processo educativo, de acordo com os recursos de intelecção que o educando já dispõe. Os hábitos reflexivos do pensar não podem ser aprendidos teoricamente, em seus passos, em vista de uma aplicação prática que se dará mais tarde ${ }^{208}$. A experiência educativa se distingue, pois, como experiência inteligente da qual o pensamento participa ${ }^{209}$.

E para isso, não sendo o pensar um caso de "combustão espontânea"210, torna-se fundamental a concepção metodológica da aprendizagem baseada em problemas efetivamente experienciados pela pessoa em crescimento.

O crescimento cognitivo é apreendido, construtivamente, como o processo em que as estruturas e os instrumentos do pensamento - e do agir, portanto -, que integram a personalidade, vão se desenvolvendo, organizando-se, lapidando-se, na medida em que são sobrecarregados por problemas na experiência. O aprendizado é, desse modo, um "processo de solução de problemas no qual o sujeito que aprende está ativamente envolvido" e que, assim, é "guiado pelos discernimentos dos próprios sujeitos diretamente envolvidos". Dá-se, processual e experiencialmente, concomitantemente à confrontação ativa com a realidade externa e, assim, à descoberta e à construção linguística dos mundos objetivo e social. Trata-se de concepção que passa por Dewey, Piaget, Kohlberg, sendo, finalmente, assimilada por Habermas ${ }^{211}$.

A criança lida com objetos físicos, com outras pessoas e consigo mesma, mediada pelo universo linguístico em que ingressa comunicativa e gradualmente. Na interação, enfrenta os mais simples e básicos problemas, na descoberta de um mundo externo que se distingue de seu universo interior. Diante deles, exercita seu pensar, ainda rudimentar, pouco elaborado $^{212}$ :

Ela não começa com um conjunto de objetos prontos dos quais extrai um significado comum; ela tenta aplicar em cada nova experiência tudo aquilo das experiências anteriores que possa ajudá-la a entender. E, na medida em que esse processo de constante apreensão e experimentação é

\footnotetext{
${ }^{208}$ DEWEY, Reconstruction in philosophy, 2004, p. 106.

${ }^{209}$ TEIXEIRA, A pedagogia de Dewey, 1980, p. 116.

${ }^{210}$ DEWEY, How we think, 1997, p. 12.

211 HABERMAS, Consciência moral e agir comunicativo, 2003, p. 50; HABERMAS, Teoria do agir comunicativo, Tomo 01, 2012, p. 135 e 137.

${ }^{212}$ DEWEY, How we think, 1997, p. 157 e 158; HABERMAS, Teoria do agir comunicativo, Tomo 01, 2012, p. 136.
} 
bem sucedido ou refutado pelos resultados, seus conceitos tomam corpo e clareza $^{213}$.

No exemplo de Dewey, a criança "descobre" o cachorro, vendo-o, ouvindo-o, acariciando-o. Mais, percebe que pode transpor dessa experiência para a subsequente, "expectativas de certos modos característicos de comportamento". Com isso, frente a novos estímulos, perplexidades nas experiências que seguem, pode assumir, diante do indício de um "cachorro", uma "atitude de antecipação". Assim, pode "chamar gatos de pequenos cachorros, ou cavalos de grandes cachorros". E isso, até que, experimentando seus conceitos incipientes, certos traços sejam confirmados, enfatizados, outros abandonados pela experiência mal sucedida ${ }^{214}$. Renovam-se as experiências, com significados que se constroem e se reconstroem no horizonte do universo linguístico e cultural que a criança integra.

Os conhecimentos e recursos adquiridos e aperfeiçoados em cada experiência alteram a percepção, o olhar do sujeito em crescimento sobre as experiências ulteriores, cada vez mais complexas. Doravante, ele se depara com novos objetos, perspectivas e problemas, antes não percebidos e que impõem, novamente, o reajustamento de suas perspectivas e estruturas cognitivas. Requerem novas capacidades, novos conhecimentos, cujo desenvolvimento, a partir de seu exercício, faz reiniciar, continuamente, o processo de crescimento cognitivo e de reconstrução do universo experiencial ${ }^{215}$.

Assim, a experiência educativa orientada, a partir de problemas, ao desenvolvimento cognitivo do educando, no medium da linguagem, favorece a liberdade de inteligência, da mente "disciplinada", em sua conversa internalizada: a "genuína liberdade", na acepção deweyana. Pois promove o cultivo dos "bons hábitos", reflexivos, de pensar, com a apreensão mais densa dos significados das situações práticas em que o sujeito se vê envolvido; com a inferência, a partir do inventário cognitivo preexistente, em contínua ampliação e reconstrução, de respostas mais adequadas às questões que se lhe apresentam; com a reflexão e correlata ação e interação mais inteligente no mundo, intelectualmente autônoma, na medida em que orientada sem a tutela externa. O sujeito torna-se capaz de mais educação, mais crescimento, mais reconstrução positiva das experiências, pois emancipado do agir irrefletido, o rotineiro, habitual, imerso nas

\footnotetext{
${ }^{213}$ DEWEY, How we think, 1997, 128 e 129.

${ }^{214}$ DEWEY, How we think, 1997, 128;

${ }^{215}$ DEWEY, Reconstruction in philosophy, 2004, p. 51; DEWEY, Experiência e educação, 2010, p. 76.
} 
convicções inquestionadas do mundo da vida; ou o impulsivo, à mercê dos apetites, das circunstâncias $^{216}$, dos impulsos libidinais incontidos ${ }^{217}$.

Tudo isso em comunicação, a partir de perplexidades que o sujeito encara nas experiências compartilhadas com o grupo social, o que, afinal, é possibilitado pela ambiência discursiva que se abriu e incluiu o outro. Traz para o processo educacional o educando, suas experiências e suas dificuldades experienciais. Afinal, para que aja a aprendizagem, resume Dewey, tudo o que se pretende como conteúdo pedagógico tem de derivar da experiência comum (e dos problemas) dos educandos ${ }^{218}$.

É dessa forma que a educação dialógica se realiza como aprendizagem baseada em problemas. Enriquece-se como processo linguístico de busca cooperativa de solução aos problemas teóricos e prático-morais efetivamente vivenciados pelos educandos. Aproveita o potencial racional da linguagem para a promoção do crescimento cuja atualização é diretamente proporcional à inclusão, à participação, à cooperação, ao compartilhamento. Tal como, diga-se a propósito, a experiência democrática que antecipa e promove.

iii) Desenvolvimento da consciência moral. Sob a abordagem moral cognitivista, o desenvolvimento da capacidade cognitiva e da competência e da disposição comunicativa, a partir do diálogo direcionado - com o pensar reflexivo - para solução de problemas, conflui ao processo de desenvolvimento moral. Em Habermas, culmina com o discurso prático, representativo do estágio da autonomia pós-convencional. Em síntese, o crescimento moral é um crescimento cognitivo que capacita o sujeito ao aproveitamento do potencial racional prático do processo linguístico de entendimento, no qual fora formado.

Os recursos de intelecção, em permanente reconstrução, permitem ao sujeito a orientação por pretensões de verdade em relação ao mundo objetivo. Delas pode prestar contas em discursos teóricos. Possibilitam, também, sua orientação por pretensões de correção, em relação ao mundo social, capacitando-o e dispondo-o à participação em discursos práticos: medium que permite examinar se determinada norma encontra fundamentação ética, "no interior do horizonte não-problemático de uma forma de vida

\footnotetext{
216 DEWEY, Democracy and education, 1916, p. 192; DEWEY, How we think, 1997, p. 63, 66 e 67; DEWEY, Reconstruction in philosophy, 2004, p. 106; DEWEY, Experiência e educação, 2010, p. 48.

${ }^{217}$ FREUD, Psicologia das massas e análise do eu, 2011, p. 43.

${ }^{218}$ DEWEY, Experiência e educação, 2010, p. 75.
} 
concreta" ou se, moralmente, pode ser justificada de modo imparcial, no interesse simétrico de uma comunidade linguística não-circunscrita ${ }^{219}$.

A razão comunicativa assume o "fardo da vida moral" pós-metafísica, possibilitando, como sugere Dewey, em sua reconstrução filosófica, o tratamento inteligente, experimental, metódico e falibilista dos conflitos de ação ${ }^{220}$. Chama para si a tarefa de aferir o valor da conduta humana, distinguindo juízos corretos dos incorretos, na intersubjetividade da práxis discursiva, em que se opõem dialeticamente crítica e fundamentação, com base em razões ${ }^{221}$.

Para chegar aí, a estrutura que subjaz a faculdade de julgamento moral forma-se, conforme supramencionado, a partir de problemas - agora práticos - que, sobrecarregando o inventário cognitivo da pessoa em crescimento, exigem sua reorganização criativa:

O desenvolvimento moral significa que a pessoa em crescimento transforma e diferencia de tal maneira as estruturas cognitivas já disponíveis em cada caso que ela consegue resolver melhor do que anteriormente a mesma espécie de problemas, a saber, a solução consensual de conflitos de ação moralmente relevantes ${ }^{222}$.

O modelo composto por três estágios morais de conduta ou interação, sugerido por Dewey e incorporado por Habermas, com a revisita ao pensamento de Kohlberg, permite visualizar, nesse percurso, primeiro, a amoralidade da criança, que não dispõe de faculdades e categorias racionais prontas e inatas, anteriores e independentes da experiência, "para criar a ciência e instituir a moral"223 ; depois, com o ingresso no universo da linguagem do grupo social, a participação heterônoma em suas convenções, tradições, valores e perspectivas existenciais; finalmente, como resultado do processo de crescimento, a capacidade do sujeito de assumir uma atitude hipotética em relação aos padrões normativos de sua experiência social, de modo a, no discurso, criticá-los em sua pretensão de correção, justificando, ainda, as pretensões de validade que assumir como suas. Em qualquer caso, valendo-se dos recursos adquiridos na referida experiência, da qual, afinal, emergiu como individualidade.

\footnotetext{
${ }^{219}$ HABERMAS, Consciência moral e agir comunicativo, 2003, p. 212 e 213; HABERMAS, Teoria do agir comunicativo, Tomo 01, 2012, p. 49 e 50; HABERMAS, Direito e democracia, Vol. 01, 2012, p. 202 e 203.

${ }^{220}$ DEWEY, Reconstruction in philosophy, 2004, p. 95.

${ }^{221}$ DEWEY, Ethics, 2008, p. 09; DEWEY, John. The study of ethics. A syllabus. Ann Arbor: The Inland Press, 1879, p. 01; HABERMAS, Consciência moral e agir comunicativo, 2003, p. 147, 155 e 197; HABERMAS, Teoria do agir comunicativo, Tomo 01, 2012, p. 49 e 50.

${ }^{222}$ HABERMAS, Consciência moral e agir comunicativo, 2003, p. 154 e 155.

${ }^{223}$ FREITAG, A questão da moralidade, 1989, p. 13.
} 
No estágio pré-convencional, começa a ser construído linguisticamente o universo exterior e o interior da criança, mediados pelas pessoas de referência (a mãe, o pai, a família, etc.), com quem a criança interage e por meio das quais o mundo vem a ela, sob um determinado enfoque. São essas as pessoas que determinam as experiências que a criança tem; que lhes confere significado; que apresentam expectativas e padrões de comportamento, pela aprovação ou reprovação, pela premiação ou sanção ${ }^{224}$. No exemplo de Dewey, sob a influência imediata dos impulsos e reagindo diretamente aos estímulos de calor, frio, dor, barulho, luz, etc.,

A criança com fome pega a comida. Para ela, este ato é inocente e natural. Mas vem a reprovação; é advertida de que foi malcriada, desrespeitosa, "gulosa"; de que deveria esperar até ser servida, até chegar a sua vez. Vem a ela a consciência de que seus atos têm outras conexões além daquela única que havia atribuído: a imediata satisfação da fome ${ }^{225}$.

Como destaca Habermas, nesse estágio de interação, a criança avança ao ponto de já distinguir, no mundo exterior em construção, o outro que, como ela, tem seu mundo subjetivo próprio. Consegue, ademais, assumir a atitude, a perspectiva do outro - a segunda pessoa $(t u)$ - em relação a ela $(e u)$ e sabe que o outro também o faz: "A criança coloca-se na pele de outrem e percebe que o outro fará o mesmo". E, assim, pode coordenar a ação na singularidade e concretude da relação recíproca entre falante-ouvinte. Sem a percepção, ainda, do mundo social do qual $e u$ e $t u$ fazem parte ${ }^{226}$.

O ingresso no estágio convencional (heterônomo) é marcado, então, pela reorganização dos equipamentos cognitivos, pela pessoa em crescimento, de modo tal que pode assumir a perspectiva de terceira pessoa em relação à interação social. Pode, então, na posição do observador externo, ressignificar a reciprocidade das orientações da ação $e u$-tu, instaurada no estágio pré-convencional, dentro de um contexto social ampliado.

A criança internaliza os padrões, as instituições e as formas de vida transmitidas pelo grupo social. Ancora-os em seu próprio eu como se fossem suas, pressupondo seu assentimento. Nesse processo, aquelas expectativas de comportamento concretas e

224 DEWEY, Reconstruction in philosophy, 2004, p.54; HABERMAS, Consciência moral e agir comunicativo, 2003, p. 188.

${ }^{225}$ DEWEY, Ethics, 2008, p. 169.

${ }^{226}$ HABERMAS, Consciência moral e agir comunicativo, 2003, p. 176 e 179. 
particulares das pessoas de referência delas se desvinculam. Passam a compor um mundo social de normas, valores e expectativas a que todos, ego e alter, estão submetidos ${ }^{227}$.

Nesse estágio, porém, a pessoa aceita com "pequena reflexão crítica"228 o universo social e normativo no qual fora inserido linguisticamente. Este forma o pano de fundo isento de problemas com o qual a pessoa se identifica e dentro do qual se move existencialmente. É dele que extrai os modelos hermenêuticos consentidos para a coordenação da ação 229 .

Desse modo, a moral convencional vem marcada pela heteronomia do ajustamento inquestionado e ingênuo ao mundo social. Nele, a facticidade e a validade, inabaláveis, não se distinguem. As dificuldades experienciadas - e que conduzem à reorganização reflexiva dos instrumentos cognitivos e morais - não permitem a problematização "ir tão fundo a ponto de por a perder as vantagens de uma eticidade existente" ${ }^{230}$.

Finalmente, com o continuum experiencial de crescimento, a pessoa atinge o estágio pós-convencional da consciência moral. O processo de desenvolvimento e reconstrução do inventário mental, descortinando ao sujeito sentidos mais densos das experiências intersubjetivamente vivenciadas, equipa-o ao distanciamento suficiente e, com ele, à assunção da atitude hipotética diante dos quais as convenções são desprovidas de sua validade fática nativa. O mundo social convencional é moralizado: na colisão possível entre ego e alter, entre o eu e o nós, ele se decompõe em normas e valores cuja pretensão de validade deve ser resgatada, racionalmente, no âmbito do discurso ${ }^{231}$.

A moralidade, assim, descola-se das instituições internalizadas pela criança. Passa a radicar procedimentalmente no discurso, do qual o sujeito, agora, pode participar de forma competente. Nele, se opõe a facticidade de uma norma vigente e sua legitimidade, referida ao assentimento dos atingidos enquanto participantes da práxis argumentativa ${ }^{232}$.

\footnotetext{
${ }^{227}$ HABERMAS, Consciência moral e agir comunicativo, 2003, p. 180, 188 e 189; HABERMAS, Teoria do agir comunicativo, Tomo 02, 2012, p. 66 e 67.

${ }^{228}$ DEWEY, Ethics, 2008, p. 12.

${ }^{229}$ HABERMAS, Consciência moral e agir comunicativo, 2003, p. 166 e 211; HABERMAS, Teoria do agir comunicativo, Tomo 01, 2012, p. 138.

${ }^{230}$ HABERMAS, Consciência moral e agir comunicativo, 2003, p. 213.

${ }^{231}$ DEWEY, Ethics, 2008, p. 14; HABERMAS, Consciência moral e agir comunicativo, 2003, p. 156 e 195 ; HABERMAS, Teoria do agir comunicativo, Tomo 01, 2012, p. 35.

${ }^{232}$ FREITAG, A questão da moralidade, 1989, p. 36; HABERMAS, Consciência moral e agir comunicativo, 2003, p. 116; HABERMAS, Direito e democracia, Vol. 01, 2012, p. 50 e 199.
} 
Nem mesmo os princípios morais, os mais genéricos e abstratos, podem ser afirmados de antemão, fora do âmbito de processos linguísticos de entendimento ${ }^{233}$. O brocardo jurídico de que "Entre as leis (...) é a justiça quem decide",234, somente tem sentido, doravante, quando o conteúdo do justo é preenchido dialogicamente, sob o princípio do discurso.

Em Dewey e em Habermas, a autonomia moral, projetada pelo iluminismo, aparece como a participação competente na intersubjetividade da linguagem em que a moralidade é racionalmente construída. E isso, a partir do processo de aprendizagem - nesse sentido, ele mesmo um processo moral -, inerente à experiência da comunicação linguística ${ }^{235}$.

iv) Pedagogia diretiva e o papel docente. O percurso cognitivo e moral da heteronomia à autonomia, repleta de exigências comunicativas e experimentada intersubjetivamente, dá a direção da experiência educativa. Indica o sentido diretivo da educação para a democracia à qual o ser humano não tende naturalmente ${ }^{236}$.

Afastar-se, com Dewey, da filosofia de extremos exige o cuidado de não trocar, inadvertidamente, a imposição unilateral de padrões da verdade e da moral, que marcara o passado autoritário brasileiro, pela "indulgência" irrestrita, pela ausência de direção do processo educativo. A negação do autoritarismo não induz a aposta, na outra ponta, numa formação espontânea, pode-se dizer mágica, de hábitos de pensar, agir e conviver comunicativos - e, com isso, democráticos - pela criança deixada livremente a si ${ }^{237}$.

Como destacado, a liberdade de inteligência e a autonomia moral são resultados de processos de aprendizagem. Contrapõem-se à "ilusão de liberdade" da mente comandada por forças das quais não tem nenhum controle (o impulso, o acaso, etc.) e que faz o princípio da continuidade operar negativamente, "isolando a pessoa em um nível baixo de desenvolvimento, de forma a limitar posteriormente sua capacidade de crescimento" 238 .

\footnotetext{
${ }^{233}$ HABERMAS, Consciência moral e agir comunicativo, 2003, p. 199.

${ }^{234}$ BARBOSA, Rui. Oração aos moços. Edição popular anotada por Adriano da Gama Kury. 5ª Ed. Rio de Janeiro: Fundação Casa de Rui Barbosa, 1997, p. 37.

${ }^{235}$ DEWEY, Experiência e natureza, 1980, p. 29 e 39; DEWEY, Reconstruction in philosophy, 2004, p. 105; HABERMAS, Consciência moral e agir comunicativo, 2003, p. 197; HABERMAS, Direito e democracia, Vol. 01, 2012, p. 50 e 191.

${ }^{236}$ DEWEY, Freedom and culture, 1988, p. 88 e 97.

${ }^{237}$ DEWEY, How we think, 1997, p. 43; DEWEY, Experiência e educação, 2010, p. 38.

${ }^{238}$ DEWEY, Experiência e educação, 2010, p. 38 e 67.
} 
Nesse sentido, é fundamental, na experiência educativa, a atuação docente diretiva: apresentando o caminho, regulando as condições ambientais e, também, transmitindo conteúdos, valores e padrões de convivência que, em interação com as experiências e as capacidades de que o educando já dispõe, levem-no ao crescimento ${ }^{239}$.

Aliás, nas etapas iniciais da educação, o diálogo aparece, muito mais, como modelo e possibilidade de interação. Orienta uma experiência na qual sobressai, ainda, a transmissão de informações, de expectativas e de regras do uso da linguagem, visando ao ingresso da criança no universo linguístico e no mundo da vida compartilhado ${ }^{240}$.

Afinal de contas, é do me convencional - formado pelo conjunto de atitudes, expectativas e práticas do grupo social, internalizado pelo sujeito - que a personalidade pode, então, na expressão de si mesmo, emergir como eu. Sua inteligência se dá na esteira da conversação com os outros. A inferência de respostas aos problemas experienciados, que compõe o pensar reflexivo, não pode se realizar sem um mínimo de experiências e conhecimentos anteriores $^{241}$.

O paradigma discursivo, de qualquer forma, faz-se presente aqui, na medida em que toda essa atuação do educador se ampara em sua condição de porta-voz de um consenso ainda não problematizado pelo educando. Ele integra o processo linguístico de atribuição de sentidos, como membro do grupo, participante, o mais amadurecido, e, por isso, como um líder das atividades, com maiores responsabilidades. Não como observador externo; jamais como um ditador. Ele parte da confiabilidade, da resgatabilidade discursiva das pretensões de validade que embasam a experiência educativa. Mas não está imune à crítica e ao discurso que antecipa. A posição de docente, em suma, não lhe autoriza afirmar, de uma vez por todas, o sentido único do processo de ensino-aprendizagem ${ }^{242}$.

A tarefa educativa revela, nesse ponto, toda sua complexidade e sutileza. Pois cumpre ao docente direcionar o crescimento da criança, equipando-a cognitivamente para tanto, dentro de um universo experiencial determinado, a partir do qual pode pensar, falar e agir. E isso de modo tal que, ao orientar o horizonte experiencial do educando, descortine (e não feche) possibilidades de novas e diferentes experiências; estimule (e não negue)

\footnotetext{
${ }^{239}$ DEWEY, Experiência e educação, 2010, p. 38, 41 e 46.

${ }^{240}$ BOUFLEUER, Pedagogia da ação comunicativa, 2001, p. 78.

${ }^{241}$ MEAD, Mind, self and society, 1992, p. 47, 141, 171, 175, 209 e 222; DEWEY, Experiência e natureza, 1980, p. 52; DEWEY, How we think, 1997, p. 12.

${ }^{242}$ BOUFLEUER, Pedagogia da ação comunicativa, 2001, p. 78; HABERMAS, Consciência moral e agir comunicativo, 2003, p. 43; DEWEY, Experiência e educação, 2010, p. 60.
} 
experiências e significações de que o educando já é capaz no exercício de seu pensar; promova (e não impeça) a problematização da experiência transmitida. Abra-se à autonomia do diálogo, e não habitue à preguiça e servidão mental, à aceitação passiva e heterônoma de $\operatorname{dogmas}^{243}$.

A atuação do docente, nesse sentido, deve ocorrer de modo inversamente proporcional ao crescimento cognitivo e moral do educando. Reduz-se de acordo com a competência da pessoa em crescimento para o enfrentamento dos problemas e lacunas em sua experiência, sem a tutela e o amparo docente, valendo-se de significados assimilados e construídos de forma cada vez mais crítica.

v) Diálogo interdisciplinar. Da fixação do discurso como paradigma da experiência educativa decorre, em termos de conteúdos educacionais, a afirmação do diálogo interdisciplinar como princípio da organização didático-pedagógica.

E se afirma, aqui, como premissa filosófica. Com efeito, para o enfrentamento do cientificismo, do tecnicismo, da fragmentação da razão, cindida em seus momentos constitutivos, e do saber, encapsulado em culturas de especialistas, é a filosofia que assume, tanto para Dewey como para Habermas, a tarefa de agente de ligação, mediador hermenêutico "poliglota"244.

Ambos destacam, em seus diagnósticos da modernidade, a regressão que acompanhou o progresso técnico-científico, apoiado no aspecto cognitivo-instrumental da racionalidade e atualizado em especialidades que retalham cartesianamente a realidade, sem conversar entre si. Estas, renunciando ao potencial de aprendizagem ínsito à confrontação e integração de suas singularidades e particularismos, somaram, à incompletude do saber, a cisão. As técnicas e as ciências puderam avançar autopoieticamente sobre seu próprio objeto, perdendo a referência a outros pontos de vista, aos aspectos sociais e morais que envolve, bem como se desligando de sentidos atribuídos comunicativamente. Assim, longe de concretizar a aposta ingênua do iluminismo num

${ }^{243}$ DEWEY, How we think, 1997, p. 12177, 198 e 199; DEWEY, Experiência e educação, 2010, p. 38 e 39. ${ }^{244}$ DEWEY, John. The quest for certainty: a study of relation of knowledge and action. New York: Minton, Balch \& Company, 1929, p. 311; HABERMAS, Modernidade - um projeto inacabado, 1992, p. 109 e 110; HABERMAS, Consciência moral e agir comunicativo, 2003, p. 32 e 33; BITTAR, Eduardo C. B. Justiça e liberdade na filosofia do direito de Jürgen Habermas. Revista dos Tribunais, ano 101, vol. 918, abril/2012, p. 258. 
"feliz" Século XX, serviram, instrumentalmente, aos fins mais tétricos que a humanidade já havia experimentado ${ }^{245}$. Num continuum experiencial de "barbarização", "as lições anteriores de desumanidade do homem para com o homem foram aprendidas e se tornaram base de novos avanços de barbárie". Fizeram do século passado, pelo volume de guerras, genocídios, experiências totalitárias, dentre outras catástrofes produzidas pelo próprio homem, a "era mais assassina" de que se tem registro ${ }^{246}$.

Diante disso, para os dois filósofos, a compreensão profunda da experiência social - e, por conseguinte, sua coordenação - depende de processos de entendimento que, como "procedimentos cooperativos de interpretação" ${ }^{247}$, passam pela cooperação interdisciplinar ${ }^{248}$. Demanda uma "tradição cultural em toda sua amplitude" e não apenas as "bênçãos" dessa ou daquela ciência ou técnica ${ }^{249}$.

Nesse sentido, o diálogo emancipador, aplicado também ao saber produzido pelo homem, aparece como mecanismo de superação da degeneração pela singularização cientificista e especialista. Vencendo as "grades" disciplinares, amplia o universo do discurso, de modo a "recolocar em movimento a cooperação paralisada, como um móbile teimosamente emperrado, do fator cognitivo-instrumental com o moral-prático e o estéticoexpressivo". Recupera, na linguagem, a unidade e universalidade da razão comunicativa, aproveitando a aprendizagem do encontro entre as culturas de especialistas - as ciências, as técnicas, a moral, o direito, as artes - e entre estas e as estruturas do mundo da vida. Favorece, enfim, a permanente crítica e autocrítica do saber socialmente produzido e transmitido ${ }^{250}$.

A experiência educativa no diálogo e no diálogo interdisciplinar remete, desse modo, ao hábito de pensar, agir e conviver que, diante de problemas e conflitos na experiência cotidiana, não pode prescindir da interpenetração linguística entre os discursos

\footnotetext{
${ }^{245}$ HABERMAS, Teoría y praxis, 1990, p. 319; DEWEY, The public and its problems, 1991, p. 175; HUGO, Victor. Os Miseráveis. Tomo 02. Trad. Francisco O. Barros. São Paulo: Cosac \& Naify, 2002, p. 545.

${ }^{246}$ HOBSBAWN, Era dos extremos, 2000, p. 21 e 22; HOBSBAWN, Eric. Sobre história. Ensaios. Trad. Cid K. Moreira. São Paulo: Cia das Letras, 2013, p. 350 e 351.

${ }^{247}$ HABERMAS, Teoria do agir comunicativo, Tomo 01, 2012, p. 138.

${ }^{248}$ SIEBENEICHLER, Flávio Bueno. Jürgen Habermas: razão comunicativa e emancipação. $3^{\underline{a}}$ ed. Rio de Janeiro: Tempo Brasileiro, 1989, p. 52.

${ }^{249}$ HABERMAS, Modernidade - um projeto inacabado, 1992, p. 116; HABERMAS, Consciência moral e agir comunicativo, 2003, p. 33.

250 HABERMAS, Consciência moral e agir comunicativo, 2003, p. 33; HABERMAS, Verdade e justificação, 2009, p. 96.
} 
científicos; as orientações axiológicas e expectativas normativas; e as interpretações e expressões subjetivas $^{251}$.

Abre-se, enfim, na leitura deweyana, para o crescimento cujo aprofundamento num dado objeto, direção ou especialidade não inibe nem prejudica o crescimento geral. Pelo contrário, promove-o, ao somar, acrescentar, agregar, ampliando e enriquecendo, complementarmente, as experiências individuais e sociais; descortinando novas possibilidades de experimentação; distinguindo caminhos para novos crescimentos, em outras direções, movimentando de forma positiva o continuum experiencial da humanidade como um todo ${ }^{252}$.

vi) A participação da sociedade na educação. A fundamentação da experiência educativa nos processos de entendimento, que formam o "centro do mundo da vida", torna imprescindível sua não assimilação pelos sistemas. São desastrosas as distorções que decorrem da colonização sistêmica da educação, quando compreendida sua dimensão de uma experiência em que, pela via comunicativa, são renovados os componentes do mundo da vida racionalizado (personalidade, sociedade e cultura $)^{253}$.

Em vista de seus fins constitucionalmente instituídos e comunicativamente orientados, a educação não pode ser tragada pelo sistema político e, assim, coordenada pela mediação do poder, contaminada pelas demandas, pressões, interesses e orientações teleológicas do aparelho governamental. Também não pode, decodificada pelo meio dinheiro, ser reduzida a propriedade privada da empresa capitalista, meio para a obtenção de lucro, deturpada pelos padrões de monetarização, da mercantilização, da competitividade e da rentabilidade ${ }^{254}$.

É nesse sentido que sobressai a atuação fundamental da sociedade civil, concebida como aquela base social comunicativa que se distingue e direciona o sistema político, sem se confundir com a sociedade econômica ${ }^{255}$.

${ }^{251}$ HABERMAS, Modernidade - um projeto inacabado, 1992, p. 116 e 119; HABERMAS, Consciência moral e agir comunicativo, 2003, p. 32 e 33.

${ }^{252}$ DEWEY, Experiência e educação, 2010, p. 36 e 37.

${ }^{253}$ HABERMAS, Teoria do agir comunicativo, Tomo 02, 2012, p. 252, 253, 587, 590 e 668.

${ }^{254}$ BOUFLEUER, Pedagogia da ação comunicativa, 2001, p. 90; HABERMAS, A inclusão do outro, 2007, p. 278; HABERMAS, Teoria do agir comunicativo, Tomo 02, 2012 p. 330 e 587.

${ }^{255}$ HABERMAS, A inclusão do outro, 2007, p. 278 e 289; HABERMAS, Direito e democracia, Vol. 02, 2011, p. 22 e 24. 
Acompanhando o fluxo comunicacional do processo democrático, a educação tem seu lugar na esfera privada, da família e do círculo de relações afetivas primárias da pessoa em crescimento, dentro do qual inicia sua socialização ${ }^{256}$. Tem lugar, também, na esfera pública, no amplo leque de ambientes e experiências de aprendizagem, destacado logo no Art. $1^{\underline{o}}$ da Lei de Diretrizes e Bases. Funcionando como momento em que a pessoa, ao extrapolar a vida privada, passa a interagir com o outro, ampliando o sentido do nós, a educação aparece, nesse ponto, como espaço fundamental de preparação e entrada na esfera pública. Finalmente, a partir das demandas, das pretensões, das discussões, das interpretações, comunicativamente empreendidas pela sociedade civil, a educação tem seu lugar no sistema político. Além de conferir-lhe tratamento institucional, pelo medium do direito, concebendo-a no âmbito de políticas públicas, a estrutura administrativa estatal atua diretamente como prestador educacional (o ensino público).

Nesse cenário amplo, a sociedade civil pode participar da educação promovendo-a, diretamente, por meio de "organizações e associações livres, não estatais e não econômicas", em espaços formais (a escola) ou informais. E lhe cumpre, ainda, como núcleo institucional da esfera pública, que precede e orienta o funcionamento do sistema político, participar ativamente da formulação, da definição, da organização, da execução e da fiscalização da legislação que rege a educação nacional, das políticas públicas educacionais, assim como do ensino ministrado pelo Poder Público ${ }^{257}$.

Dessa forma, pode promover a "estruturação pedagógica" da educação ${ }^{258}$, orientada aos seus objetivos constitucionais e amparada nos princípios educacionais, como a liberdade de ensinar, aprender e pesquisar, a pluralidade de ideias e concepções pedagógicas, a garantia do padrão de qualidade, a gestão democrática do ensino público, a obrigatoriedade e gratuidade da educação básica dos quatro aos dezessete, da observância das normas gerais da educação nacional, dentre outros previstos nos Artigos 206, 208 e 209 da Constituição.

Possibilita, assim, a restrição dos influxos sistêmicos que instrumentalizam a educação ao intuito lucrativo da empresa educacional, às demandas imediatistas do mercado de trabalho, aos objetivos do poder político desgarrado do poder comunicativo. $\mathrm{E}$

256 HONNETH, Luta por Reconhecimento, 2009, p. 159; DALLARI, Educação e preparação para a cidadania, 2009, p. 325.

${ }^{257}$ HABERMAS, Direito e democracia, Vol. 02, 2011, p. 100; HABERMAS, Teoria do agir comunicativo, Tomo 02, 2012, p. 576 e 577.

${ }^{258}$ HABERMAS, Teoria do agir comunicativo, Tomo 02, 2012, p. 667. 
pode, nessa linha, superar a (de)formação da personalidade que, diante dessa moldura sistêmica - que passa longe dos processos de formação linguística do entendimento -, acaba pautada pela racionalidade instrumental, pelo uso parasitário da linguagem, por padrões interação unilaterais, impositivos, não-dialógicos ${ }^{259}$.

A configuração jurídico-constitucional ampara uma participação da sociedade civil na educação que, estruturada pedagogicamente a partir do diálogo, pode, opondo-se à sua própria colonização, contribuir substancialmente com a reversão da colonização da democracia pelos imperativos da economia capitalista e, na história brasileira de inexperiência democrática, pela prevalência autoritária do sistema político sobre a sociedade ${ }^{260}$.

6.3. A experiência educativa, assim concebida à luz da filosofia social de Dewey e de Habermas, promove a democracia na medida em que promove a formação da individualidade no ambiente de aprendizagem que constitui o discurso.

A personalidade pode reunir, nessa experiência educativa, os recursos, as competências, os hábitos de pensar, agir e conviver que, esparramados para os diversos âmbitos da vida, permitem-lhe afirmar sua identidade, na participação cooperativa nos processos sociais. Pois pode contribuir de forma única, peculiar. E, aqui, destaca-se a atuação, como ator social, na formação discursiva da opinião e da vontade democrática. A atuação, portanto, como sujeito do direito, no sentido de autor do direito a que se submete na qualidade de destinatário ${ }^{261}$. Tudo isso, no âmbito da ação comunicativa, a partir da qual o cidadão pode cooperar para a atualização desses momentos sociais como processos linguísticos de entendimento, que se enraízam e, ao mesmo tempo, renovam criticamente as tradições culturais, os modos de interação e os padrões de socialização que compõem o mundo da vida comum. Linguagem e entendimento, conjungidos na educação e na democracia, podem, enfim, produzir e atribuir os sentidos compartilhados que determinem o aproveitamento social e moral do saber produzido e disseminado, com o auxílio das

${ }^{259}$ HABERMAS, Teoria do agir comunicativo, Tomo 02, 2012, p. 330 e 667.

${ }^{260}$ FAORO, Os donos do poder, 1995, p. 747 e 748; BOUFLEUER, Pedagogia da ação comunicativa, 2001, p. 96; RICUPERO, Sete lições sobre as interpretações do Brasil, 2008, p. 168; HABERMAS, Teoria do agir comunicativo, Tomo 02, 2012, p. 587

${ }^{261}$ HABERMAS, Direito e democracia, Vol. 01, 2012, p. 157. 
ciências e técnicas modernas. Permitem a definição, pelos atores sociais autônomos, dos espaços e conteúdos da política, do direito e dos demais sistemas de ação ${ }^{262}$.

Diante da concepção da democracia como forma de vida que congrega a razão, a moral, a política e o direito, sob o discurso - apostando, então, em seus potenciais cognitivos e práticos -, a experiência educativa que promove, dialogicamente, o desenvolvimento cognitivo e moral da pessoa em crescimento, conferindo-lhe competência e disposição comunicativa, não se distingue daquela que prepara para o exercício da cidadania.

O preparo da cidadania compreendido, evidentemente, com um conteúdo bastante ampliado $^{263}$. Pois remete aos processos linguísticos de entendimento que tem lugar na vida em sociedade, compartilhada e solidária, e por meio dos quais se definem os significados das experiências sociais e os sentidos para onde caminham.

Falar, por isso, em educação para a democracia, amparando-se em Dewey e Habermas, é ver como indissociáveis os objetivos constitucionais de "pleno desenvolvimento da pessoa" e de "preparo para o exercício da cidadania".

${ }^{262}$ HABERMAS, Teoría y praxis, 1990, p. 318, 319 e 331; HABERMAS, Teoria do agir comunicativo, Tomo 01, 2012, p. 496; HABERMAS, Teoria do agir comunicativo, Tomo 02, 2012, p. 253.

${ }^{263}$ DALLARI, Educação e preparação para a cidadania, 2009, p. 345. 


\section{CONSIDERAÇÕES FINAIS}

No trajeto que propôs e, agora, conclui, a tese se debruçou sobre a questão da educação para a democracia no Brasil. E a enfrentou fundamentando o debate na filosofia social de John Dewey e de Jürgen Habermas. Apoiou-se, dessa forma, em duas tradições distintas, o pragmatismo norte-americano, em que se insere a filosofia reconstruída deweyana, e a Escola de Frankfurt, em que Habermas figura como a principal expressão da "segunda geração". Sem negligenciar as particularidades e as diferenças em seus caminhos teóricos, foram destacadas as convergências significativas de seus pensamentos, ambos, no final das contas, pertencentes à “família intelectual” do iluminismo ${ }^{1}$.

Sob a perspectiva assim enredada, educação e democracia podem ser concebidas como experiências comunicativas indissociáveis, uma enriquecendo a outra, no percurso de

\footnotetext{
${ }^{1}$ HOBSBAWN, Eric. Sobre história. Ensaios. Trad. Cid K. Moreira. São Paulo: Cia das Letras, 2013, p. 349.
} 
realização do projeto moderno de emancipação, revisitado criticamente. Projeto dinamicamente inacabado, tal como o constitucional brasileiro.

Como se viu no Capítulo I, a Constituição Federal de 1988 marca o ponto de partida histórico e hermenêutico de um Estado Democrático de Direito que se ergue em oposição ao passado de inexperiência da democracia e da cultura de direitos humanos ${ }^{2}$. Eis um passado que, efeito do continuum experiencial, revive no presente, acomodando-se à nova ordem e limitando o alcance das transformações que nela se descortinam ${ }^{3}$. É frente a ele que o projeto constitucional há de se realizar, renovar-se e se enriquecer, dentro de circunstâncias e de possibilidades precárias, a partir de sua própria experiência e reconstrução de sua experiência pelos atores sociais ${ }^{4}$.

Pensar a educação para a democracia, nesse sentido, não implica, absolutamente, a afirmação de um fim estático, com uma configuração pronta, para o qual se marcha. Indica, antes, um processo de aprendizagem que reconstrói, na medida em que o atualiza, seu sentido emancipatório. A teoria deweyana da experiência deixa claro que a aprendizagem da democracia somente pode ser efetivada na continuidade da própria experiência democrática. Toda sua reflexão pedagógica remete a uma educação na comunidade democrática $^{5}$.

Para o enfrentamento, então, dessa questão, feita desafio ingente, diante das tarefas democratizantes herdadas do passado autoritário brasileiro, foram aprofundados e debatidos, ao longo da tese, os pontos de vista dos dois referenciais teóricos acerca da democracia e da educação.

No Capítulo II, a tese centrou o pensamento de Dewey, delineado no âmbito da proposta de reconstrução pragmatista da filosofia. Propugna que se volte ao enfrentamento racional, inteligente, dos conflitos sociais e morais que angustiam a humanidade,

${ }^{2}$ PIOVESAN, Flávia. Temas de direitos humanos. $2^{\underline{a}}$ ed. rev. ampl. e atual. São Paulo: Max Limonad, 2003, p. 328; BITTAR, Eduardo C. B. Linguagem jurídica. $5^{\underline{a}}$ Ed. São Paulo: Saraiva, 2010, p. 125.

${ }^{3}$ MOISÉS, José Álvaro. Os brasileiros e a democracia. Bases sócio-políticas da legitimidade democrática. São Paulo: Ática, 1995, p. 27; BENEVIDES, Maria Victoria de Mesquita. Em defesa da república e da democracia. In BENEVIDES, Maria Victoria de Mesquita; BERCOVICI, Gilberto; MELO, Claudinei de. Direitos humanos, democracia e república: homenagem a Fábio Konder Comparato. São Paulo: Quartier Latin, 2009, p. 727.

${ }^{4}$ MELO, Tarso de. Direitos Sociais e Resistência. Seminário proferido no âmbito da disciplina Direitos Humanos Fundamentais do Programa de Pós-graduação Stricto Sensu da Universidade de São Paulo. São Paulo, 02/05/2011; HABERMAS, Jürgen Direito e democracia: entre factibilidade e validade. Volume 02. Trad. Flávio Beno Siebeneichler. Rio de Janeiro: Tempo Brasileiro, 2011, p. 119.

${ }^{5}$ DEWEY, John. Democracy and education. An introduction to the philosophy of education. New York: The Macmillan Company, 1916, p. 117. 
incorporando, para tanto, a atitude investigativa, metódica, experimental, falibilista, que possibilitou o desenvolvimento da ciência moderna ${ }^{6}$.

Dessa perspectiva, o autor concebe a democracia, para além de seu momento político, como um ideal social e moral de autodeterminação. Une o método científico e o democrático, num processo de busca cooperativa da verdade e, também, da moral, da justiça social. Nesse quadro, a experiência democrática se funde à vida comunitária do grupo social e à demarcação experimental, por ele, do espaço do público: medium discursivo que distingue as consequências invasivas das interações sociais; identifica os problemas de coordenação social; e atua em sua solução compartilhada. Para tanto, dispõe, instrumentalmente, da estrutura governamental ${ }^{7}$.

Quanto à educação, em sua abordagem progressiva, Dewey a enraíza na experiência. Apreende o crescimento cognitivo e moral da pessoa como um processo comunicativo e compartilhado de reconstrução das experiências, a partir da solução de problemas com que se depara em seu curso. Exercita, dessa forma, o pensar reflexivo. Assim, adquirindo novos conhecimentos, habilidades e experiências e reconstruindo permanentemente seus recursos cognitivos, a pessoa em crescimento, amplia e aprofunda o significado das experiências ulteriores e se habilita à sua direção, de modo mais adequado e autônomo, em termos cognitivos e morais ${ }^{8}$.

No Capítulo III debateu a filosofia social de Habermas. Ressaltou, inicialmente, as teorias do agir comunicativo e do discurso: a práxis da argumentação voltada ao entendimento, que dá prosseguimento ao agir comunicativo, com a crítica, a tematização e a fundamentação de pretensões de validade que se tornaram controversas. Soluciona o dissenso pela mediação da linguagem em que nos constituímos como individualidade, sem o emprego, imediato ou estratégico, da violência ${ }^{9}$. Com a revisita à concepção de desenvolvimento moral de Lawrence Kohlberg - e, por meio dele, ligando-se à teoria

\footnotetext{
${ }^{6}$ DEWEY, John. Reconstruction in philosophy. Mineola/New York: Dover Publications, 2004,p. 25

${ }^{7}$ DEWEY, John, Freedom and culture. Nova York: Prometheus Books, 1989, p. 81; DEWEY, John. The public and its problems. Swallow Press/Ohio University Press/Athens, 1991, p. 33, 83, 148; BERNSTEIN, Richard J. The resurgence of pragmatism. Social research, vol. 59, n 4, 1992, p. 814 e 815; JOAS, Hans. Pragmatism and social theory. Chicago: University of Chicago Press, 1993, p. 19.

${ }^{8}$ DEWEY, Democracy and education, 1916, p. 63, 89 e 90; DEWEY, John. Experiência e educação. Trad. Renata Gaspar. Petrópolis/RJ: Vozes, 2010, p. 30.

${ }^{9}$ HABERMAS, Jürgen. Teoria do agir comunicativo. Racionalidade da ação e racionalização social. Tomo 01. Trad. Paulo Astor Soethe. Revisão Técnica Flávio Beno Siebeneichler. São Paulo: Editora WMF Martins Fontes, 2012, p. 48.
} 
deweyana de crescimento - Habermas pode colocar o discurso como representação do estágio pós-convencional, autônomo, da consciência moral ${ }^{10}$.

Construído à luz da ideia de discurso, o modelo habermasiano de democracia, como fora ressaltado, aproxima-se em muitos pontos da proposta de Dewey, no sentido de uma experiência social ampliada de autolegislação. Configura-se como um processo discursivo de formação da opinião e da vontade, num fluxo comunicacional que se inicia com a atuação da sociedade civil, na esfera pública, arena comunicativa de identificação, de debate e de tratamento de problemas comuns; de luta por reconhecimento e reconhecimento de pretensões; que, ecoando no sistema político, encontram solução institucionalizada, pelo medium do direito ${ }^{11}$.

Em relação à educação, se Habermas não possui uma versão teórica acabada, sua filosofia social permite a fixação de bases fundamentais de uma pedagogia da ação comunicativa, compreendida à luz do discurso e orientada ao desenvolvimento cognitivo e moral da pessoa. Também ela, portanto, bastante próxima das propostas progressivas de Dewey.

No Capítulo IV, finalmente, foram destacadas as confluências entre os pensamentos dos dois autores, no campo da democracia e da educação para a democracia. E, aqui, sobressai, como ponto de encontro fundamental, a linguagem, voltada ao seu telos de entendimento.

Dewey e Habermas reconhecem e apostam no inesgotável potencial racional de aprendizagem, cognitivo e prático/consumatório, inerente ao discurso. E isso, diante da abertura que ele proporciona ao outro, às suas perspectivas e experiências de vida. Ele promove e fortalece, na pessoa em permanente crescimento, uma perspectiva existencial participante numa comunidade linguística na qual as experiências e seus sentidos se ampliam, adensam-se e se enriquecem fazendo-se compartilhados.

Na horizontalidade e bilateralidade da práxis discursiva, nenhuma verdade, nenhuma justiça, nenhuma autoridade está imunizada à dialética da crítica e da fundamentação. Tornam-se, todas elas, pretensões de validade, no processo de busca cooperativa da verdade e da correção normativa. Põe-se a descoberto, assim, o

\footnotetext{
${ }^{10}$ HABERMAS, Jürgen. Consciência Moral e Agir Comunicativo. Trad. Guido A. de Almeida. Rio de Janeiro: Tempo Brasileiro, 2003, p. 155, 156 e 199.

${ }^{11}$ HABERMAS, Direito e democracia, Vol. 02, 2011, p. 22 a 25.
} 
autoritarismo e a irracionalidade de quem se coloca numa posição privilegiada, pretensamente imune à resgatabilidade discursiva do que toma dogmaticamente como verdadeiro, justo e sincero.

Daí o discurso se firmar como o lugar da autonomia, compreendida intersubjetivamente. Daí seu significado, ao mesmo tempo, radicalmente transformador. Confere à educação e à democracia "um componente revolucionário de transformação do status quo" "12. Na expressão de Bobbio, subversivo: pois subverte da concepção tradicional de poder que "desce do alto para baixo"13.

A democracia concebida discursivamente implica, nesse sentido, a horizontalidade que pode se contrapor e, enfim, romper com a verticalidade, a unilateralidade, o autoritarismo, o paternalismo não dialógico que marcaram a história brasileira de inexperiência democrática. Aponta para uma convivência que pode atualizar a metafórica "sociedade sem pai" de que fala Kelsen, apoiado no pensamento freudiano: uma experiência social e política que se desvencilhe, definitivamente, dos ranços autoritários e paternalistas, mantidos abaixo da formalidade democrática, mas com ela incompatível, e conformadores da "horda conduzida por um chefe" ${ }^{14}$.

A educação para a democracia, por sua vez, aparece como o processo de desenvolvimento cognitivo e moral em que a individualidade, constituindo-se socialmente, pode, então, afirmar-se autonomamente como eu na participação única, peculiar e imprescindível nas experiências sociais e em seus processos discursivos de interpretação pública de temas que afetam a sociedade, de formação da opinião e da vontade, de tomada de decisões coletivas sobre questões comuns.

É, enfim, educação para a emancipação, ambientada na democracia, apreendida como medium social em que se vislumbra a extensão dessa concepção aprendizagem e crescimento a "todos os membros da sociedade" 15 . Tudo isso, na tradição da modernidade, revisitada e reconsiderada ante os descaminhos e experiências de barbárie que, na dialética do esclarecimento, nela também tiveram lugar.

12 SILVA, José Afonso da. Curso de direito constitucional positivo. 33 $3^{\text {a }}$ ed. rev. e atual. São Paulo: Malheiros, 2010, p. 119.

${ }^{13}$ BOBBIO, Norberto. Qual socialismo? Discussão de uma alternativa. $2^{\mathrm{a}}$ ed. Trad. Iza de Salles Freaza. Rio de Janeiro: Paz e terra, 1987, p. 64.

${ }^{14}$ FREUD, Sigmund. Psicologia das massas e análise do eu. In Obras completas. Volume 15. Psicologia das massas e análise do eu e outros textos (1920-1923). Trad. Paulo César de Souza. São Paulo: Cia das Letras, 2011, p. 83.

${ }^{15}$ DEWEY, Democracy and education, 1916, p. 117. 
Trata-se, de qualquer forma, de experiências - a educação e a democracia - que, recusando metahistórias, metadireitos, a metafísica, trazida e criticada no âmbito do discurso, não tem metagarantias de êxito. É realizada, comunicativamente, pelos próprios sujeitos históricos que se educam. Em sua incompletude dinâmica, é potencialmente transformadora. Mas é, também, inevitavelmente arriscada, delicada, falível. Por isso, um desafio a ser enfrentado. 


\section{BIBLIOGRAFIA}

ABREU, Jayme. Atualidade de John Dewey. In BRABUCHER, John S. Importância da teoria em educação. Trad. Beatriz Osório. Série VII - Cursos e conferências Vol. 3. Rio de Janeiro: Instituto Nacional de Estudos Pedagógicos - INEP/MEC, 1961.

ABREU, Jayme. A Educação Secundária no Brasil. Ensaio de identificação de suas características principais. Revista Brasileira de Estudos Pedagógicos, Brasília, v. 86, no 212, jan./abr. 2005.

ADORNO, Theodor W. \& HORKHEIMER, Max. Dialética do Esclarecimento. Fragmentos Filosóficos. Trad. Guido Antonio de Almeida. Rio de Janeiro: Zahar, 1985.

ADORNO, Theodor W. Teoria da semicultura. Trad. Newton Ramos de Oliveira, Bruno Pucci e Cláudia B. M. de Abreu. Educação \& Sociedade nº 56, ano XVII, dez/1996.

Prismas: crítica cultural e sociedade. Trad. Augutin Wernet e Jorge Mattos Brito de Almeida. São Paulo: Ática, 1998.

Escritos sociológicos I. Obra completa 08. Trad. Agustín González Ruiz. Madrid, España: Akal, 2004.

Educação e Emancipação. São Paulo: Paz e Terra, 2004.

A teoria freudiana e o padrão da propaganda fascista. Margem esquerda: ensaios marxistas $n^{\underline{0}} 07,2006$.

ALMEIDA, Guilherme de Assis. Aula ministrada na disciplina Direitos humanos fundamentais do Programa de Pós-Graduação Stricto Sensu em Direito da Universidade de São Paulo. São Paulo, 29/04/2013.

AMARAL, M. Nazaré de C. Pacheco. Dewey: filosofia e experiência democrática. São Paulo: Perspectiva, 2007.

ARIAS, Juan. ¿Por qué Brasil no tiene indignados? Jornal El Pais, 07/07/2011. Disponível em: http://internacional.elpais.com/internacional/2011/07/07/actualidad/1309989609_8502 15.html. Acesso em 02/08/2012.

ARQUIDIOCESE DE SÃO PAULO. Brasil: nunca mais. 20ª ed. Petrópolis: Vozes, 1987. ASSIS, Machado de. Memórias Póstumas de Brás Cubas. 18ª Ed. São Paulo: Ática, 1992. 
AVRITZER, Leonardo. A moralidade da democracia: ensaios em teoria habermasiana e teoria democrática. São Paulo: Perspectiva; Belo Horizonte: Editora UFMG, 1996.

BARBOSA, Rui. Oração aos moços. Edição popular anotada por Adriano da Gama Kury. 5ª Ed. Rio de Janeiro: Fundação Casa de Rui Barbosa, 1997.

BAUMAN, Zygmunt. A modernidade líquida. Trad. Plínio Dentzien. Rio de Janeiro: Jorge Zahar, 2001.

BECK, Ulrich. La sociedad del riesgo. Hacia una nueva modernidad. Trad. Jorge Navarro e outros. Barcelona: Paidós Surcos, 2006.

BELL, Bernard Iddings. Crisis in education: a challenge to American complacency. New York: Whittlesey House, 1949.

BENEVIDES, Maria Victoria de Mesquita. A cidadania ativa. Referendo, plebiscito e iniciativa popular. $3^{\mathrm{a}}$ ed. São Paulo: Ática, 2003.

Em defesa da república e da democracia. In BENEVIDES, Maria Victoria de Mesquita; BERCOVICI, Gilberto; MELO, Claudinei de. Direitos humanos, democracia e república: homenagem a Fábio Konder Comparato. São Paulo: Quartier Latin, 2009.

BENJAMIN, Harold R. W. A educação e o ideal democrático. Trad. Beatriz Osório. Série VII - Cursos e conferências Vol. 02. Rio de Janeiro: Instituto Nacional de Estudos Pedagógicos - INEP/MEC, 1960.

BERCOVICI, Gilberto. Tentativa de instituição da democracia de massas no Brasil: instabilidade constitucional e direitos sociais na Era Vargas (1930-1964). In FONSECA, Ricardo Marcelo e SEELAENDER, Airton Cerqueira Leite. História do Brasil em perspectiva. Do Antigo Regime à Modernidade. Curitiba: Juruá, 2009.

BERNSTEIN, Richard J. The resurgence of pragmatism. Social research, vol. 59, nº 4, 1992.

BITTAR, Eduardo Carlos Bianca. A discussão do conceito de direito: uma reavaliação a partir do pensamento habermasiano. Boletim da Faculdade de Direito. Universidade de Coimbra. Vol. LXXXI, 2005.

Estudos sobre ensino jurídico: pesquisa, metodologia, diálogo e cidadania. $2^{\mathrm{a}}$

Ed. São Paulo. Atlas, 2006. 
$O$ direito na pós-modernidade (e reflexões frankfurtianas). $2^{\underline{a}}$ ed. Rio de Janeiro: Forense Universitária, 2009.

Linguagem jurídica. 5ª Ed. São Paulo: Saraiva, 2010.

Justiça e emancipação: reflexões jusfilosóficas a partir do pensamento de Jürgen Habermas. Tese apresentada em concurso de Professor Titular junto ao Departamento de Filosofia e Teoria Geral do Direito da Faculdade de Direito da Universidade de São Paulo. São Paulo, 2011.

Justiça e liberdade na filosofia do direito de Jürgen Habermas. Revista dos Tribunais, ano 101, vol. 918, abril/2012.

BOBBIO, Norberto. Qual socialismo? Discussão de uma alternativa. $2^{a}$ ed. Trad. Iza de Salles Freaza. Rio de Janeiro: Paz e terra, 1987.

O futuro da democracia. Uma defesa das regras do jogo. Trad. Marco Aurélio Nogueira. 5를. Edo de Janeiro: Paz e Terra, 1992.

Direito e Estado no Pensamento de Emmanuel Kant. $3^{3}$ ed. Brasília: Editora UNB, 1995.

BONAVIDES, Paulo. Do Estado Liberal ao Estado Social. 10ª ed. São Paulo: Malheiros, 2011.

Curso de Direito Constitucional. 26쪼 Ed. atual. São Paulo: Malheiros, 2011.

BOUFLEUER, José Pedro. Pedagogia da ação comunicativa. Uma leitura de Habermas. $3^{\mathrm{a}}$ ed. Ijuí: Unijuí, 2001.

BRUBACHER, John S. Importância da teoria em educação. Trad. Beatriz Osório. Série VII - Cursos e conferências Vol. 3. Rio de Janeiro: Instituto Nacional de Estudos Pedagógicos - INEP/MEC, 1961.

BRASIL. CÂMARA DOS DEPUTADOS. Combatendo a corrupção eleitoral. Tramitação do primeiro projeto de lei de iniciativa popular aprovado pelo Congresso Nacional. Série Ação Parlamentar, no 96. Brasília: Centro de Documentação e Informação, 1999. Disponível em: http://bd.camara.gov.br/bd/bitstream/handle/bdcamara/1942/combatendo_ corrupcao eleitoral.pdf?sequence=1. Acesso em 03/10/2012.

BRASIL. PRESIDÊNCIA DA REPÚBLICA. SECRETARIA DE DIREITOS HUMANOS (SDH/PR). Segundo Relatório Nacional do Estado Brasileiro apresentado no Mecanismo 
de Revisão Periódica Universal do Conselho de Direitos Humanos das Nações Unidas 2012. Brasília, 2012. Disponível em: http://www.direitoshumanos.gov.br. Acesso em $30 / 05 / 2012$.

BRASIL. TRIBUNAL SUPERIOR ELEITORAL. Campanha Eleições 2012. Pesquise o passado do candidato. 2012. Disponível em: http://www.tse.jus.br/hotSites/votolimpo/\#prettyPhoto. Acesso em 03/10/2012.

CARVALHO, José Murilo. Cidadania no Brasil: o longo caminho. 13ª Ed. Rio de Janeiro: Civilização brasileira, 2010.

CENTRE FOR ECONOMICS AND BUSINESS RESEARCH (CEBR). Cebr's World Economic League Table. Londres, 26/12/2013. Disponível em: http://www.cebr.com/reports/cebr-world-economic-league-table/. Acesso em 20/10/2014.

COMETTI, Jean-Pierre. Jürgen Habermas e o pragmatismo. ROCHLITZ, Rainer (coord.). Habermas e o uso público da razão. Trad. Léa Novaes. Rio de Janeiro: Tempo brasileiro, 2005.

COMITÊ NACIONAL DE EDUCAÇÃO EM DIREITOS HUMANOS. Plano Nacional de Educação em Direitos Humanos. Brasília: Secretaria Especial dos Direitos Humanos/Ministério da Educação/Ministério da Justiça/UNESCO, 2007. Disponível em: http://portal.mj.gov.br/sedh/edh/pnedhpor.pdf. Acesso em 23/01/2014.

COMPARATO, Fábio Konder. Para viver a democracia. São Paulo: Brasiliense, 1989. A afirmação histórica dos direitos humanos. 8aㅡ ed. São Paulo: Saraiva, 2013.

CUNHA, Marcus Vinicius da. Comunicação e arte, ou arte da comunicação, em John Dewey. Revista brasileira de estudos pedagógicos. Brasília, v. 86, nº 213/214, maio/dez., 2005.

John Dewey: filósofo, educador e ativista social. In DEWEY, John. Democracia e educação: capítulos essenciais Apresentação e comentários de Marcus Vinicius da Cunha. Trad. Roberto Cavallari Filho. São Paulo: Ática, 2007.

DAHL, Robert A. A democracia e seus críticos. Trad. Patrícia de Freitas Ribeiro. Revisão da tradução: Aníbel Mari. São Paulo: Editora WMF Martins Fontes, 2012.

DALLARI, Dalmo de Abreu. Educação e preparação para a cidadania. In BENEVIDES, Maria Victoria de Mesquita; BERCOVICI, Gilberto; MELO, Claudinei de. Direitos 
humanos, democracia e república: homenagem a Fábio Konder Comparato. São Paulo: Quartier Latin, 2009.

Elementos de teoria geral do estado. 29a ed. atual. São Paulo: Saraiva, 2010.

DEMO, Pedro. Cidadania menor. Algumas indicações quantitativas de nossa pobreza política. Petrópolis: Vozes, 1992.

DEWEY, John. The study of ethics. A syllabus. Ann Arbor: The Inland Press, 1879

Psychology and Social Practice. Contributions to education $\mathrm{n}^{\mathrm{o}}$ II. Chicago: University of Chicago Press, 1901.

Democracy and education. An introduction to the philosophy of education.

New York: The Macmillan Company, 1916.

The quest for certainty: a study of relation of knowledge and action. New York: Minton, Balch \& Company, 1929.

Experiência e natureza; Lógica: a teoria da investigação; A arte como experiência; Vida e educação; Teoria da vida moral. Trad. Murilo Otávio Rodrigues Paes Leme, Anísio S. Teixeira e Leônidas Gontijo de Carvalho. Coleção Os Pensadores. São Paulo: Abril Cultural, 1980.

Freedom and culture. Nova York: Prometheus Books, 1989.

The public and its problems. Swallow Press/Ohio University Press/Athens, 1991.

How we think. Mineola, New York: Dover Publications, 1997.

Reconstruction in philosophy. Mineola/New York: Dover Publications, 2004.

Democracia e educação: capítulos essenciais Apresentação e comentários de Marcus Vinicius da Cunha. Trad. Roberto Cavallari Filho. São Paulo: Ática, 2007.

O desenvolvimento do pragmatismo americano. Trad. Renato Rodrigues

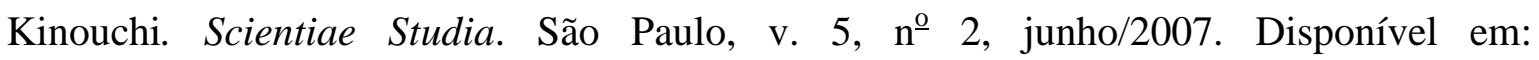
http://www.scielo.br/scielo.php?script=sci_arttext\&pid=S1678-31662007000200006\&lng= en\&nrm=iso. Acesso em 06/06/2014.

Ethics. The Later Works 1925-1953. Volume 07 (1932). Edited by Jo Ann Boydston. Southern Illinois University, 2008. 
Experiência e educação. Trad. Renata Gaspar. Petrópolis/RJ: Vozes, 2010.

DICKSTEIN, Morris (ed.). The Revival of Pragmatism: new essays on social thought, law and culture. Durham/London: Duke University Press, 1998.

DUARTE, Nestor. A ordem privada e a organização política nacional, São Paulo/Rio de Janeiro/Recife/Porto Alegre: Companhia Editora Nacional, 1939.

FAORO, Raymundo. Os donos do poder. Formação do patronato político brasileiro. Volume 02. 11 $1^{\underline{a}}$ Ed. São Paulo: Globo, 1995.

FERRAZ JUNIOR. Tércio Sampaio. Responsabilidade sem culpa, culpa sem responsabilidade na sociedade tecnológica. In FABIANI, Emerson Ribeiro (org.). Impasses e aporias do direito contemporâneo. Estudos em homenagem a José Eduardo Faria. São Paulo: Saraiva, 2011.

Introdução ao estudo do direito. Técnica, decisão, dominação. $6^{\mathrm{a}}$ ed. rev. e amp. São Paulo: Atlas, 2011.

FREIRE, Paulo. Educação e mudança. Trad. Moacir Gadotti e Lilian Lopes Martin. Rio de Janeiro: Paz e terra, 1979.

Pedagogia do Oprimido. 50 $0^{\mathrm{a}}$ ed. rev. e atual. Rio de Janeiro: Paz e Terra, 2011.

Educação como prática de liberdade. 14ํㅡㄹ Ed. Rio de Janeiro: Paz e Terra, 2011.

FREITAG, Bárbara. A questão da moralidade: da razão prática de Kant à ética discursiva de Habermas. Tempo social. Revista de Sociologia da USP. Volume 01, no 02, São Paulo, $2^{\underline{0}}$ semestre de 1989.

A teoria crítica: ontem e hoje. São Paulo: Brasiliense, 2004.

FREUD, Sigmund. Psicologia das massas e análise do eu. In Obras completas. Volume 15. Psicologia das massas e análise do eu e outros textos (1920-1923). Trad. Paulo César de Souza. São Paulo: Cia das Letras, 2011.

FRIEDMAN, Milton. Capitalismo e Liberdade. Trad. Luciana Carli. São Paulo: Abril Cultural, 1984.

GADOTTI, Moacir. Pensamento pedagógico brasileiro. São Paulo: Ática, 1991. História das ideias pedagógicas. $8^{\mathrm{a}}$ ed. São Paulo: Ática, 2002. 
GHIRALDELLI JUNIOR, Paulo. Pragmatismo e neopragmatismo. In RORTY, Richard. Para realizar a América. O pensamento de esquerda no Século XX na América. Trad. Paulo Ghiraldelli Jr., Alberto Tosi Rodrigues e Leoni Henning. Rio de Janeiro: DP\&A Editora, 1999.

Filosofia e história da educação brasileira. Barueri: Manole, 2003.

GRAU, Eros. Constituição e Reforma Universitária. Jornal Folha de São Paulo. São Paulo, 23/01/2005.

HÄBERLE, Peter. El estado constitucional. Trad. Héctor Fix-Fierro. México: UNAM, 2003.

HABERMAS, Jürgen. A nova opacidade: a crise do Estado-providência e o esgotamento das energias utópicas. Revista de Comunicação e Linguagem, $\mathrm{n}^{\mathrm{o}}$ 02, 1985.

Um perfil sociológico-político: entrevista com Jürgen Habermas. Trad. Wolfgang Leo Maar. Dossiê Habermas. Novos estudos. CEBRAP 18, Setembro/1987

Teoría y praxis: estudios de filosofia social. Trad. Salvador Más Torres e Carlos Moya Espí. 2ª ed. Madrid: Tecnos, 1990.

Escritos sobre moralidad y eticidad. Trad. Manuel Jiménes Redondo. Barcelona: Ediciones Paidós/ICE Universidad Autónoma de Barcelona, 1991.

Modernidade - um projeto inacabado. In ARANTES, Otília B. Fiori e ARANTES, Paulo Eduardo. Um ponto cego no projeto moderno de Jurgen Habermas: arquitetura e dimensão estética depois das vanguardas. São Paulo: Brasiliense, 1992.

O discurso filosófico da modernidade. Trad. Luiz Sérgio Repa e Rodnei Nascimento. São Paulo: Martins Fontes, 2002.

Consciência Moral e Agir Comunicativo. Trad. Guido A. de Almeida. Rio de Janeiro: Tempo Brasileiro, 2003.

A inclusão do outro. Estudos de teoria política. Trad. George Sperber, Paulo Astor Soethe e Milton Camargo Mota. 3ª ed. São Paulo: Loyola, 2007.

A ética da discussão e a questão da verdade. Organização e introdução de Patrick Savidan. Trad. Marcelo Brandão Cipolla. 2ª ed. São Paulo: Martins Fontes, 2007. Verdade e justificação. Ensaios filosóficos. Trad. Milton Camargo Mota. $2^{\underline{a}}$ ed. São Paulo: Loyola, 2009. 
Direito e democracia: entre factibilidade e validade. Volume 01. $2^{\mathrm{a}}$ Ed. Trad. Flávio Beno Siebeneichler. Rio de Janeiro: Tempo Brasileiro, 2012.

Direito e democracia: entre factibilidade e validade. Volume 02. Trad. Flávio Beno Siebeneichler. Rio de Janeiro: Tempo Brasileiro, 2011.

Teoria do agir comunicativo. Racionalidade da ação e racionalização social. Tomo 01. Trad. Paulo Astor Soethe. Revisão Técnica Flávio Beno Siebeneichler. São Paulo: Editora WMF Martins Fontes, 2012.

Teoria do agir comunicativo. Sobre a crítica da razão funcionalista. Tomo 02. Trad. Flávio Beno Siebeneichler. São Paulo: Editora WMF Martins Fontes, 2012.

HERÁCLITO DE ÉFESO. Fragmentos. Sobre a natureza. Trad. José Cavalcanti de Souza. In SOUZA, José Cavalcante de (seleção de textos e supervisão). Os Pré-socráticos. Coleção Os Pensadores. São Paulo: Abril Cultural, 1973.

HESPANHA, António Manuel. O caleidoscópio do direito. O direito e a justiça nos dias e no mundo de hoje. $2^{\mathrm{a}}$ ed. Coimbra: Almedina, 2009.

HICKMAN, Larry A (ed.). Reading Dewey. Interpretations for a postmodern generation. Bloomington/Indianapolis: Indiana University Press, 1998.

HOBSBAWN, Eric. Era dos extremos. O breve século XX: 1914-1991. 2a ed. Trad. Marcos Santarrita. Rev. Téc. Maria Célia Paoli. São Paulo: Cia das Letras, 2000.

Sobre história. Ensaios. Trad. Cid K. Moreira. São Paulo: Cia das Letras, 2013.

HONNETH, Axel. Democracy as reflexive cooperation: John Dewey and the theory of democracy today. Political Theory, vol. 26, nํㅜ 06, Dez/1998.

Luta por Reconhecimento. A gramática moral dos conflitos sociais. $2^{\mathrm{a}}$ ed. São Paulo: Editora 34, 2009.

HORKHEIMER, Max. Teoria tradicional e Teoria Crítica. In HORKHEIMER, Max, BENJAMIN, Walter; ADORNO, Theodor; HABERMAS, Jürgen. Textos Escolhidos. Coleção “Os Pensadores”. Trad. José Lino Grunnewald e outros. $2^{\text {a }}$ ed. São Paulo: Abril cultural, 1983.

HORTA, José Luiz Borges. Direito Constitucional da Educação. Belo Horizonte: Decálogo, 2007. 
HUGO, Victor. Os Miseráveis. Tomo 02. Trad. Francisco O. Barros. São Paulo: Cosac \& Naify, 2002.

INSTITUTO BRASILEIRO DE GEOGRAFIA E ESTATÍSTICA (IBGE). Pesquisa Nacional de Saneamento Básico - PNSB 2008. Rio de Janeiro, 2010. Disponível em: http://www.ibge.gov.br/home/estatistica/populacao/condicaodevida/pnsb2008/PNSB_2008 .pdf. Acesso em 20/10/2012.

INSTITUTO DE PESQUISA DATAFOLHA. Protestos sobre o aumento de tarifa dos transportes II. PO 813688. São Paulo, 18/06/2013. Disponível em: http://datafolha.folha.uol.com.br/opiniaopublica/2013/06/1297619-cresce-apoio-aprotestos-contra-a-tarifa-de-onibus-entre-paulistanos.shtml. Acesso em 26/06/2013.

INSTITUTO DE PESQUISA ECONÔMICA APLICADA (IPEA). Sistema de Indicadores de Percepção Social (SIPS). Saúde. Brasília, 2011. Disponível: http://www.ipea.gov.br/portal/images/stories/PDFs/SIPS/110207_sipssaude.pdf. Acesso em $22 / 05 / 2014$.

INSTITUTO PAULO MONTENEGRO/AÇÃO EDUCATIVA. INAF BRASIL 2011: Indicador de Alfabetismo Funcional. Principais resultados. São Paulo, 2012. Disponível em: http://www.ipm.org.br/download/informe_resultados_inaf2011_versao\%20final_1207 2012b.pdf. Acesso em 04/08/2012.

JAMES, William. Pragmatismo. Textos selecionados. Trad. Pablo Rubén Mariconda. Coleção Os pensadores XL. São Paulo: Abril Cultural, 1974.

JOAS, Hans. Pragmatism and social theory. Chicago: University of Chicago Press, 1993.

KANT, Immanuel. A paz perpétua e outros opúsculos. Trad. Artur Morão. Lisboa: Edições $70,2004$.

Fundamentação da metafísica dos costumes. Lisboa: Edições 70, 2008.

KELSEN, Hans. A democracia. Trad. Ivone Castilho Benedetti e outros. São Paulo: Martins Fontes, 2000.

KOHLBERG, Lawrence. La Democracia en la escuela secundaria: educando para una sociedad mas justa. Trad. Maria Mercedes Oraison. Chaco: Universidad Nacional del Nordeste, 1992. 
LAFER, Celso. A reconstrução dos direitos humanos: um diálogo com o pensamento de Hannah Arendt. São Paulo: Cia das Letras, 1988.

LEAL, Victor Nunes. Coronelismo, enxada e voto. O município e o regime representativo no Brasil. São Paulo: Alfa-omega, 1978.

LUHMANN, Niklas. Sociologia do direito II. Trad. Gustavo Bayer. Rio de Janeiro: Tempo brasileiro, 1985.

LIMA LOPES, José Reinaldo. O direito na história. Lições introdutórias. $2^{\mathrm{a}}$ ed. revista. São Paulo: Max Limonad, 2002.

LIMA NETO, Vicente Correia e outros. Nota Técnica $n^{o}$ 05. Estimativas do déficit habitacional brasileiro (PNAD 2007-2012). Brasília: IPEA, novembro/2013. Disponível em: http://www.ipea.gov.br/portal/images/stories/PDFs/nota_tecnica/131125_notatecnicadi rur05.pdf. Acesso em 21/05/2014.

LYOTARD, Jean-François. The postmodern condition: a report on knowledge. Trad. Geoff Bennington e Brian Massumi. Minneapolis: University of Minnesota Press, 1984.

MARSHALL, T. H. Cidadania, classe social e status. Trad. Meton Porto Gadelha. Rio de Janeiro: Zahar, 1967.

MARTINS, Luís. O patriarca e o bacharel. $2^{\underline{a}}$ ed. São Paulo: Alameda, 2008.

MEAD, George Herbert. Mind, self and society: from the standpoint of a social behaviorist. Edited and with a introduction by Charles W. Morris. Chicago/London: The University of Chicago Press, 1992.

MELLO, Celso Antônio Bandeira de. Curso de Direito Administrativo. $27^{\mathrm{a}}$ ed. rev. e atual. São Paulo: Malheiros, 2010.

MELO, Tarso de. Direitos Sociais e Resistência. Seminário proferido no âmbito da disciplina Direitos Humanos Fundamentais do Programa de Pós-graduação Stricto Sensu da Universidade de São Paulo. São Paulo, 02/05/2011.

MENDONÇA, Ana Waleska P. C. e outros. Pragmatismo e desenvolvimentismo no pensamento educacional brasileiro dos anos de 1950/1960. Revista Brasileira de Educação, v. 11 n 0 31 jan./abr. 2006.

MOISÉS, José Álvaro. Os brasileiros e a democracia. Bases sociopolíticas da legitimidade democrática. São Paulo: Ática, 1995. 
MOREIRA, Luiz. Fundamentação do direito em Habermas. $3^{\mathrm{a}}$ ed. rev. atual. e amp. Belo Horizonte: Mandamentos, 2004.

MOTA, Carlos Guilherme. Viagem incompleta. A experiência brasileira. Formação: histórias. $3^{\text {a }}$ ed. São Paulo: Editora SENAC, 2009.

MURARO, Darcísio Natal. A importância do conceito no pensamento deweyano: relações entre pragmatismo e educação. (Doutorado - Programa de Pós-graduação em Educação. Área de concentração: Educação e filosofia). Faculdade de Educação da Universidade de São Paulo, 2008.

Relações entre a filosofia e a educação de John Dewey e a de Paulo Freire. Educação \& Realidade, vol. 38, $\mathrm{n}^{\mathrm{o}}$ 03, jul./set. 2013. Disponível em: http://www.ufrgs.br/edu_realidade. Acesso em 24/06/2014.

NOBRE, Marcos. Apontamentos sobre a Pesquisa em Direito no Brasil. Novos Estudos. CEBRAP, São Paulo, v. 66, 2003.

Luta por reconhecimento: Axel Honneth e a teoria crítica. In HONNETH, Axel. Luta por reconhecimento: a gramática moral dos conflitos sociais. Trad. Luiz Repa. São Paulo: Editora 34, 2009.

NÚCLEO DE ESTUDOS DA VIOLÊNCIA (NEV/USP). $4^{\circ}$ Relatório nacional sobre os direitos humanos no Brasil. São Paulo: Universidade de São Paulo/Núcleo de Estudos da Violência, 2010. Disponível em: http://www.nevusp.org/downloads/down248.pdf. Acesso em 31/01/2014

NÚCLEO DE ESTUDOS DA VIOLÊNCIA (NEV/USP). $5^{\circ}$ Relatório nacional sobre os direitos humanos no Brasil (2001-2010). São Paulo: Universidade de São Paulo/Núcleo de Estudos da Violência, 2012. Disponível em: http://www.usp.br/imprensa/wpcontent/uploads/5\%C2\%BA-Relat\%C3\%B3rio-Nacional-sobre-os-Direitos-Humanos-noBrasil-2001-2010.pdf. Acesso em 21/05/2014.

OLIVEIRA, Manfredo Araújo de. Escola e sociedade: questão de fundo de uma educação libertadora. Revista de Educação AEC. Brasília, ano 18, nº 71, jan/mar. 1989.

ORGANIZAÇÃO PARA A COOPERAÇÃO E DESENVOLVIMENTO ECONÔMICO (OCDE). PISA 2009 Results: Executive summary. 2010. Disponível em: http://www.pisa.oecd.org. Acesso em 25/04/2012. 
Country note. Brazil. Programme for International Student Assessment.

Results from PISA 2012. Disponível em: http://www.oecd.org/pisa/keyfindings/PISA2012-results-brazil.pdf. Acesso em 17/09/2014.

PROGRAMA DAS NAÇÕES UNIDAS PARA O DESENVOLVIMENTO (PNUD). Human Development Report 2013. The Rise of the South: Human Progress in a Diverse World. Nova Iorque, 2013. Disponível em: http://hdr.undp.org/sites/default/files/reports/14 /hdr2013_en_complete.pdf. Acesso em 31/01/2014.

PEIRCE, Charles S. Escritos coligidos. Seleção de Armando Mora D’Oliveira. Trad. Armando Mora D’Oliveira e Sérgio Pomerangblum. Coleção Os pensadores. $2^{\underline{a}}$ ed. São Paulo: Abril Cultural, 1980.

PINZANI, Alessandro. Habermas. Porto Alegre: Artmed, 2009.

PIOVESAN, Flávia. Temas de direitos humanos. $2^{\underline{a}}$ ed. rev. ampl. e atual. São Paulo: Max Limonad, 2003.

Direitos humanos e o direito constitucional internacional. $13^{\underline{a}}$ ed. rev. e atual. São Paulo: Saraiva, 2012.

RANIERI, Nina Beatriz Stocco. Educação superior, direito e estado: na lei de diretrizes e bases (lei no 9.394/96). São Paulo: Edusp/FAPESP, 2000.

O estado democrático de direito e o sentido da exigência de preparo para o exercício da cidadania, pela via da educação. Tese apresentada para inscrição em concurso visando à obtenção do título de Livre-docente, junto ao Departamento de Direito de Estado da Faculdade de Direito da Universidade de São Paulo. São Paulo, 2009.

RIBEIRO, Darcy. O povo brasileiro. São Paulo: Cia das Letras, 2006.

RICOEUR, Paul. O Justo. A justiça como regra moral e como instituição. . Tomo 01. Trad. Ivone C. Benedetti. São Paulo: Martins Fontes, 2008.

RICUPERO, Bernardo. Sete lições sobre as interpretações do Brasil. 2ª ed. São Paulo: Alameda, 2008.

ROCHA, Eliezer Pedroso da. O princípio da continuidade e relação entre interesse e esforço em Dewey. Tese (Doutorado - Programa de Pós-graduação em Educação. Área de concentração: Educação e filosofia). Faculdade de Educação da Universidade de São Paulo, 2011. 
RORTY, Richard. A filosofia e o espelho da natureza. Trad. Jorge Pires. Lisboa: Publicações Dom Quixote, 1988.

Consecuencias del pragmatismo. Trad. José Miguel Esteban Cloquell. Madrid: Tecnos, 1996.

SAFATLE, Vladimir. Sem partido. Jornal Folha de São Paulo, 25/06/2013. Disponível em http://www1.folha.uol.com.br/colunas/vladimirsafatle/2013/06/1300700-sem-partido.sh

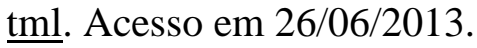

SARAMAGO, José. As palavras de Saramago: catálogo de reflexões pessoais, literárias e políticas. Sel. e Org. Fernando Gómez Aguilera. Trad. Rosa F. d'Aguiar e outros. São Paulo: Cia das Letras, 2010.

SARLET, Ingo Wolfgang. Dignidade da pessoa humana e direitos fundamentais na Constituição Federal de 1988. Porto Alegre: Livraria do advogado, 2011.

SARLET, Ingo Wolfgang e outros. Curso de direito constitucional. $2^{-}$ed. rev., atual. e amp. São Paulo: RT, 2013.

SAVIANI, Dermeval. A nova lei da educação: trajetória, limite e perspectivas. $9^{\mathrm{a}}$ ed. Campinas: Autores Associados, 2004.

Escola e democracia. Edição comemorativa. Campinas: Autores associados, 2008.

SCHEFFLER, Israel. A linguagem da educação. Trad. Balthazar Barbosa Filho. São Paulo: Edusp/Saraiva, 1974.

SCHILLING, Flávia. O que cabe à educação fazer em direitos humanos? VI Encontro Anual da Associação Nacional de Direito Humanos - Pesquisa e Pós-graduação ANDHEP, Brasília/DF, 17/09/2010.

SIEBENEICHLER, Flávio Beno. Jürgen Habermas: razão comunicativa e emancipação. $3^{\mathrm{a}}$ ed. Rio de Janeiro: Tempo Brasileiro, 1989.

SILVA, José Afonso da. Curso de direito constitucional positivo. $33^{\mathrm{a}}$ ed. rev. e atual. São Paulo: Malheiros, 2010.

SOUSA JUNIOR, José Geraldo. Sociologia jurídica: condições sociais e possibilidades teóricas Porto Alegre: Sergio Antonio Fabris Editor, 2002. 
SOUSA SANTOS, Boaventura de. Crítica da razão indolente: contra o desperdício da experiência. $7^{\text {a }}$ Ed. São Paulo: Cortez, 2009.

TEIXEIRA, Anísio. Filosofia e educação. Revista Brasileira de Estudos Pedagógicos. Rio de Janeiro, v.32, n.75, jul./set. 1959. Disponível em http://www.bvanisioteixeira.ufba.br/ artigos/filosofia.html. Acesso em 07/01/2013.

Nota Introdutória. BENJAMIN, Harold R. W. A educação e o ideal democrático. Trad. Beatriz Osório. Série VII - Cursos e conferências Vol. 02. Rio de Janeiro: Instituto Nacional de Estudos Pedagógicos - INEP/MEC, 1960.

A pedagogia de Dewey (Esboço da teoria de educação de John Dewey). In DEWEY, John, Experiência e natureza; Lógica: a teoria da investigação; A arte como experiência; Vida e educação; Teoria da vida moral. Trad. Murilo Otávio Rodrigues Paes Leme, Anísio S. Teixeira e Leônidas Gontijo de Carvalho. Coleção Os Pensadores. São Paulo: Abril Cultural, 1980.

TRINDADE, Christiane Coutheux. Educação, sociedade e democracia no pensamento de John Dewey. Dissertação (Mestrado - Programa de Pós-graduação em Educação. Área de concentração: Educação e filosofia). Faculdade de Educação da Universidade de São Paulo, 2009.

VIOLA, Sólon Eduardo Annes. Direitos humanos no Brasil: abrindo portas sob neblina. In SILVEIRA, Rosa Maria Godoy e outros (org.). Educação em direitos humanos: Fundamentos teórico-metodológicos. João Pessoa: Editora Universitária, 2007.

WAISELFISZ, Julio Jacobo. Mapa da violência 2014. Os jovens do Brasil. Versão Preliminar. Rio de Janeiro: FLACSO/Brasil, 2014. Disponível em: http://www.mapadaviolencia.org.br/pdf2014/Mapa2014_JovensBrasil_Preliminar.pdf. Acesso em 20/10/2014.

WALKS, Leonard J. John Dewey and the challenge of progressive education. International journal of progressive education. Vol. 09, nํㅜ 01, 2013.

WEFFORT, Francisco C. Por que democracia? 2ª ed. São Paulo: Brasiliense, 1984. O populismo na política brasileira. $5^{\underline{a}}$ ed. São Paulo: Paz e terra, 2003. 